Readers, Sanctity, and History in Early Modern Spain

Pedro de Ribadeneyra, the Flos sanctorum, and Catholic Community

by

Jonathan Edward Greenwood

A thesis submitted to the Faculty of Graduate and Postdoctoral Affairs in partial fulfillment of the requirements for the degree of

Master of Arts

in

History

Carleton University

Ottawa, Ontario

(C) 2011

Jonathan Edward Greenwood 


$\begin{array}{ll}\begin{array}{l}\text { Library and Archives } \\ \text { Canada }\end{array} & \begin{array}{l}\text { Bibliothèque et } \\ \text { Archives Canada }\end{array} \\ \begin{array}{l}\text { Published Heritage } \\ \text { Branch }\end{array} & \begin{array}{l}\text { Direction du } \\ \text { Patrimoine de l'édition }\end{array} \\ \begin{array}{l}\text { 395 Wellington Street } \\ \text { Ottawa ON K1A 0N4 } \\ \text { Canada }\end{array} & \begin{array}{l}\text { 395, rue Wellington } \\ \text { Ottawa ON K1A ON4 } \\ \text { Canada }\end{array}\end{array}$

Your file Votre référence

ISBN: 978-0-494-83071-0

Our file Notre référence

ISBN: 978-0-494-83071-0

NOTICE:

AVIS:

The author has granted a nonexclusive license allowing Library and Archives Canada to reproduce, publish, archive, preserve, conserve, communicate to the public by telecommunication or on the Internet, loan, distribute and sell theses worldwide, for commercial or noncommercial purposes, in microform, paper, electronic and/or any other formats.

The author retains copyright ownership and moral rights in this thesis. Neither the thesis nor substantial extracts from it may be printed or otherwise reproduced without the author's permission.

L'auteur a accordé une licence non exclusive permettant à la Bibliothèque et Archives Canada de reproduire, publier, archiver, sauvegarder, conserver, transmettre au public par télécommunication ou par l'Internet, prêter, distribuer et vendre des thèses partout dans le monde, à des fins commerciales ou autres, sur support microforme, papier, électronique et/ou autres formats.

L'auteur conserve la propriété du droit d'auteur et des droits moraux qui protège cette thèse. $\mathrm{Ni}$ la thèse ni des extraits substantiels de celle-ci ne doivent être imprimés ou autrement reproduits sans son autorisation.
In compliance with the Canadian Privacy Act some supporting forms may have been removed from this thesis.

While these forms may be included in the document page count, their removal does not represent any loss of content from the thesis.
Conformément à la loi canadienne sur la protection de la vie privée, quelques formulaires secondaires ont été enlevés de cette thèse.

Bien que ces formulaires aient inclus dans la pagination, il n'y aura aucun contenu manquant.

\section{Canadä}


The Department of History recommends to the Faculty of Graduate and Postdoctoral Affairs acceptance of the thesis

\title{
Readers, Sanctity, and History in Early Modern Spain Pedro de Ribadeneyra, the Flos sanctorum, and Catholic Community
}

\author{
submitted by \\ Jonathan Edward Greenwood, B.A. Hons. \\ in partial fulfilment of the requirements \\ for the degree of Master of Arts
}

Paul Nelles, Thesis Supervisor

Dominique Marshall, Chair, Department of History

Carleton University

20 September 2011 


\section{ABSTRACT}

In early modern Spain and amongst Jesuits, the names Lutheran, Calvinist, and Anglican were synonymous with heresy. This thesis focuses on the Jesuit Pedro de Ribadeneyra (1527-1611) and his vernacular compilation of saints' lives the Flos sanctorum (Flower of the Saints) in late sixteenth and early seventeenth-century Spain. While the theologies between confessions changed extensively, each drew religious inspiration and solace from reading the lives of exemplars immersed in their respective confessional discourses. While Catholicism maintained the cult and the lives of saints in devotion, Catholics toiled to make hagiography into a collection of genres fit for official veneration. Extant since the early church, hagiography was a collection of literary genres about saints, which included their lives, accounts of their relics and miracles, as well as liturgical readings about them. In the early modern era, these texts provided a representation of the impact of print on religious life. Originally, early modern compilations of saints' lives derived from the Legenda aurea (Golden Legend) by Jacobus de Voragine, which circulated broadly since the thirteenth century. By the sixteenth-century and especially after the Protestant Reformations, readers distrusted the lives found in the Legenda aurea. The Flos sanctorum revealed the changing perceptions of sainthood and saints' lives after the Council of Trent. Amongst Catholic hagiographers, Jesuits maintained a prominent position in this culture of reading, writing, and circulating saints' lives. As the central figure of my thesis, Ribadeneyra operated in Madrid and compiled a collection of saints' lives that corresponded with early modern Catholic discourse in the late-sixteenth and early-seventeenth centuries. His collection of saints' lives, the Flos sanctorum, was exceptionally popular amongst early modern Catholic readers. Simon Ditchfield acknowledges that hagiography contains an ignored component of the histories of early modern science, religion, and politics. The exceptions to this trend are the works on early modern hagiography by Ditchfield, Alison Knowles Frazier, and David Collins. Ribadeneyra's Flos sanctorum scarcely appears in the historiography of early modern Catholcism or Spain. Meanwhile, the study of early modern life-writing has expanded to include fruitful discussions on the lives of Protestant reformers, present in the work of Irena Backus, James Michael Weiss, and Robert Kolb. This expansion, however, has not included the study of early modern Spanish or Catholic hagiography. Themes and approaches evident in the historiography of life-writing amongst Protestant confessions appear infrequently in discussions of early modern Catholicism or Spain. This study will examine the saints' lives in Ribadeneyra's Flos sanctorum, which provided narratives for early modern Catholics to assert a religious identity. 
IN MEMORIAM

STEPHEN MICHAEL GREENWOOD

(1959-2010) 


\section{ACKNOWLEDGEMENTS}

After combing through reader prologues, both modern and early modern, I hoped for some proficiency at ackowledging the efforts of others in this thesis before you. I first and foremost have to thank my supervisor, Paul Nelles, for his suggestion of this project, his time spent questioning my assumptions and evidence, as well as his subtle, but firm way of curbing my linguistic excesses. He is also responsible for introducing me to the engaging realm of early modern religion and the history of the book and guiding me through the Monumenta historica Societatis Iesu, while still an undergraduate. I must also extend my gratitude towards Marc Saurette for supporting this project and even reviewing my Latin translations. His fervour for medieval religious history is infectious, its insights have helped me throughout this thesis.

As well, I cannot forget the support that Jen Evans provided in my academic life paired with her encouraging publication and sparking an interest in all things visual (yes, even banknotes). For Dominique Marshall, I must praise for her tireless efforts at opening a dialogue amongst graduate students, at taking a keen curiosity in my work, as well as her help in acquiring funding. I also appreciate the assistence that Micheline White provided when I worked as her research assistant. Most important was her enthusiasm and the constant interest she took in my project. I also reserve gratitude for my new supervisor Richard L. Kagan for reading my thesis, offering constant advice, and suggesting monographs and articles to me.

I am also indebted to the staffs of numerous libraries, which includes the Thomas Fisher Rare Book Room at Toronto. I reserve a special mention for Christine Taylor at Carleton's Inter-Library Loans Department and her ability to find even the most obscure 
materials. Apart from the comedy of errors at St. Paul's University's Library about a 'homeless guy' amongst the Latin tomes (the one day I forgot to shave), their staff was courteous and always generous in their assistance. I cannot overlook the help of the Hispanic Society of America and the Biblioteca nacional de España for assisting me in getting digital and microfilm versions of early modern Flos sanctorum since I could not travel to New York and Madrid respectively.

I must also thank my other colleagues in the department for their brilliant discussions, consolation, and humour. In this, I single out Erin Bell, Ceilidhe Wynn, Emmanuel Hogg, and the litany of laughter surrounding room 437. I turned to my friends to help remember the world outside of academia. I must thank Justin Rivest, Kathryn Desplanque, Sarah and Johnny Wakim, and Nick Groen for their encouragement and patience, especially when I started to babble about saints. In particular, Justin's knowledge of early modern Europe provoked connections and associations I scarcely had considered before. He also suggested I present my work in Chapel Hill, North Carolina, which was a great idea.

I have to thank my famillies, first the Greenwood-Olivet clan, here in Toronto, Ottawa, Portland, Texas, and Guatemala. Of course, I have to express thanks to my parents, Emilia Olivet-Rossal and Kim Greenwood, as well as my brothers Nery and William (he is only Guillermo on weekends). Without my parents, Ribadeneyra's 1599 and the 1601 Flos sanctorum would have remained out of my reach. I am blessed for my grandmother Haydee Rossal-Paíz not only as an exemplar, but also as a continuous reminder of the world's joys outside of books. I also dedicate this thesis to the memory of Uncle Bargoons who departed this past December. Furthermore, I have to include my 
new family, the Summerfields, especially my parents-in-law, John and Virginia, who encourage the pursuit of reading and knowledge but also the appreciation of life and the outdoors. I cannot exclude other members of the Summerfield clan of the furry persuasion. They reminded me that stressing over this thesis was of little concern, especially if they did not receive pats or tummy rubs. So thank you Abby, Aspen, TBone, Katya, and Jack.

Finally, I have to thank my dearest Margaret. Without her companionship, her sustained belief in me, as well as her ability to make me recall what is important, I would have lacked the inspiration to finish my thesis. I also owe much to her, since her Christmas gift provided the microfilms of Villegas's Flos sanctorum from Madrid. I am eternally grateful that fate, Paul's historiography class, and Fernand Braudel brought us together. On a more personal matter, all I will say is Laus Deo. 


\section{TABLE OF CONTENTS}

ABSTRACT

ACKNOWLEDGEMENTS

TABLE OF CONTENTS VII

LIST OF FIGURES

LIST OF APPENDICES Y X

ABBREVIATIONS $\quad$ X1

INTRODUCTION

CHAPTER 1: RIBADENEYRA AND THE FLOS SANCTORUM 32

CHAPTER 2: 'TOLLE, LEGE' AND CATHOLIC COMMUNITY 81

Towards a History of Reading in Early Modern Spain 83

Reading Ribadeneyra and the Flos sanctorum $\quad 94$

$\begin{array}{ll}\text { Ribadeneyra as Reader } & 101\end{array}$

CHAPTER 3: THE SAINT AS EXEMPLAR IN EARLY MODERN

$\begin{array}{lr}\text { CATHOLICISM } & 122\end{array}$

Catholicism and Saintly Imitation $\quad 125$

The Society of Jesus and Saintly Imitation $\quad 128$

Surius, Saints' Lives, and Imitation 137

The Saint as Exemplar in Ribadeneyra's Flos Sanctorum 142

Rlbadeneyra on the Founders Dominic and Francts of Asstst

Rıbadeneyra on the Doctors Thomas Aqumas, Bonaventure, and Augustme $\quad 146$

Rlbadeneyra on the Apostles Peter, Paul, John, and James the Greater 153

Rlbadeneyra on the Martyrs Sebastlan, Justus and Pastor, as well as Stephen $\quad 160$

$\begin{array}{ll}\text { CONCLUSION } & 164\end{array}$ 


\section{LIST OF FIGURES}

Figure 1: Political Map of Early Modern Spain ............................................... 31

Figure 2: The Geography of Production of Ribadeneyra's Works ......................... 38

Figure 3: Geography of Production of Castilian Flos Sanctorum not by Ribadeneyra

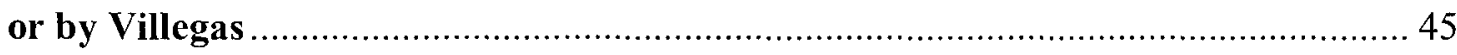

Figure 4: Geography of Production of Castilian Flos Sanctorum by Villegas and by

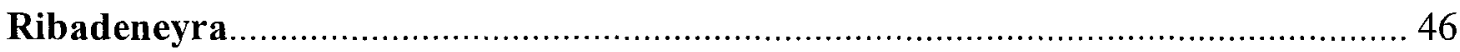

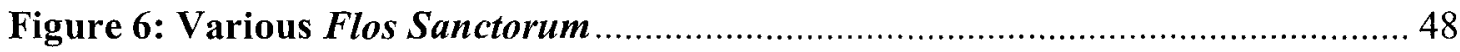

Figure 7: Textual Geneologies of Flos sanctorum based on Appendices 6 and 7... 118 


\section{LIST OF APPENDICES}

APPENDIX 1: PRINTED FLOS SANCTORUM IN EARLY MODERN SPAIN... 170

1.1 Flos before Lippomano and Surius 170

1.2 Flos influenced by Lippomano and Surius 172

APPENDIX 2: PRINTED WORKS OF PEDRO DE RIBADENEYRA 179

APPENDIX 3: BOOKS PRINTED BY THE MADRIGAL PRINT HOUSE OF MADRID. 184

3.1 Pedro Madrigal Period: 1586-1594 184

3.2 Widow of Madrigal (Maria Rodriguez Rivalde) Period: 1595-1604 192

APPENDIX 4: BOOKS BY THE SÁNCHEZ HOUSE OF MADRID 199

4.1 Pre-Valladolid Era (1590-1601). 199

4.2 Valladolid Era (1602-1606) 207

4.2.1 Printed in Madrid 207

4.2.2 Printed in Valladolid 211

4.3 Post-Valladolid Era (1607-1611) 215

APPENDIX 5: SAINTS OF VARIOUS FLOS SANCTORUM 219

APPENDIX 6: THE ANNOTATIONS FROM RIBADENEYRA'S FLOS SANCTORUM. 231

APPENDIX 7: THE ANNOTATIONS FROM VILLEGAS'S FLOS SANCTORUM 


\section{ABBREVIATIONS}

BCJ: Augustin de Backer, Aloys de Backer, and Carlos Sommervogel. Bibliothèque de la Compagnie de Jésus. 12 vols. Brussels: Oscar Schepens, 1890-[1932]. Reprint, Louvain: Bibliothèque S.I., 1960.

BM: Cristóbal Pérez Pastor. Bibliografia madrileña, o, Descripción de las obras impresas en Madrid. 3 vols. Madrid: Tipografía de Revista de Archivos, Bibliotecas, y Museos, 18911907.

CIV: Mariano Alcocer y Martínez. Catálogo razonado de obras impresas en Valladolid (14811800). Valladolid : Casa Social Católica, 1926.

DHCJ: Diccionario histórico de la Compañia de Jesús, biográfico-temático. Eds. Charles E. O'Neill and Joaquín M. Domínguez. 4 vols. Rome: Institutum Historicum Societatis Iesu, 2001.

DHEE: Diccionario de histórica eclesiástica de España. Eds. Quintín Aldea Vaquero, Tomás Marín Martínez, and José Vives. 4 vols. Madrid: Instituto Enrique Flórez, 1972-1975.

DIE: Juan Delgado Casado. Diccionario de impresores españoles (siglos $X V$-XVII). 2 vols. Madrid: Arco/Libros, 1996.

IB: Iberian Books: Books Published in Spanish or Portuguese or on the Iberian Peninsula before 1601 / Libros ibéricos: Libros publicados en español o portugués o en la Península Ibérica antes de 1601. Ed. Alexander S. Wilkinson. Leiden and Boston: Brill, 2010.

JS: José Simón Díaz. Jesuitas de los siglos XVI y XVII: escritos localizados. Madrid: Fundación Universitaria Española, 1975.

MHSI: Monumenta historica Societatis Iesu.

MLCT: Monumenta liturgica Concilii Tridentini.

OCSL: Oxford Companion to Spanish Literature. Ed. Philip Ward. Oxford: Clarendon Press, 1978.

TM: Yolanda Clemente San Román. Tipobibliografia madrileña: La imprenta en Madrid en el siglo XVI (1566-1600). 3 vols. Kassel: Edition Reichenberger, 1998. 


\section{INTRODUCTION}

Saints in early modern Catholicism were exemplars of confession-based holiness and imitators of Christ's life. They served as intercessors between the living and Christ in heaven. Saints emulated not only the sanctity of Christ, but that of other saints. Hagiographies allowed accessibility to the exceptional nature of saints. Extant since the early church, hagiography was a collection of literary genres about saints, which included their lives, accounts of their relics and miracles, and liturgical readings about them. ${ }^{1}$ In my thesis, I explore how the Society of Jesus in early modern Spain drew on hagiography to express a confessional identity in three ways: the imitation of saintly exemplars, the manufacture of genealogies of sanctity and texts, and the assembly of an orthodox community of readers. In particular, this thesis focuses on Pedro de Ribadeneyra (15271611) and his Castilian compilation of saints' lives, the Flos sanctorum (Flower of the Saints), in late sixteenth and early seventeenth-century Spain. ${ }^{2}$ Ribadeneyra's Flos sanctorum provided a representation of the impact of print on religious life. His compilation, akin to most hagiographies, favoured the vernacular. Since the late-fifteenth century, when printing began in the Iberian Peninsula, printed hagiographies appeared predominately in either Castilian or Catalan. ${ }^{3}$ While Latin remained the official language

\footnotetext{
${ }^{1}$ Thomas Head, Medieval Hagiography (New York: Routledge, 2001), xiv.

${ }^{2}$ René Aigrain, L'hagiographie: ses sources, ses méthodes, son histoire (Paris: Bloud et Gay, 1953. Reprint, Brussels: Société des Bollandistes, 2000), 305-42; Brenda Dunn-Lardeau, "De La Légende dorée de Jacques de Voragine aux Fleurs des vies des saints de Pedro de Ribadeneira," in Les voies de l'invention aux XVIe et XVIIe siècles, eds. Bernard Beugnot and Robert Melançon (Montréal: Université de Montréal, 1993), 23-34.

${ }^{3}$ For example, of the hagiographies printed in Spain from 1450 to 1550 , there are fourteen in Latin, whereas the remaining 118 are in the vernacular (Catalan, Valencian, and Castilian). D. de Courcelles, "Espagne de 1450 à 1550," in Hagiographies, ed. Guy Philipart (Turnhout: Brepols, 1994), 1:156-71, 176. This trend continues past 1550, but José Aragüés Aldaz notes that despite these trends, Latin and vernacular hagiographical traditions shared a common heritage. The main problem is the exaggeration of 'national', instead of religious hagiography. José Aragüés Aldaz, "Tendencias y realizaciones en el
} 
of the church after Trent, Catholic devotional literature by Jesuits opted to use local vernaculars.

Originally, early modern compilations of saints' lives derived from the Legenda aurea (Golden Legend) by Jacobus de Voragine, which circulated broadly since the thirteenth century. By the sixteenth-century and especially after the Protestant Reformations, readers distrusted the lives found in the Legenda aurea. In this context, hagiographers renovated the collection of genres through authenticating sources and verifying information about saints' lives. Hagiographical compilations also increasingly adhered to discourses built upon explicit statements of doctrine that shaped conduct. Hagiographies represented textually the ongoing doctrinal conflicts between Spanish parishes, religious orders, and the Roman Church in the late-sixteenth century. The Flos sanctorum revealed the changing perceptions of sainthood and saints' lives after the Council of Trent. Amongst Catholic hagiographers, Jesuits maintained a prominent position in this culture of reading, writing, and circulating saints' lives.

Ribadeneyra compiled a collection of saints' lives that corresponded with early modern Catholic discourse in the late-sixteenth and early-seventeenth centuries. His collection of saints' lives, the Flos sanctorum, was exceptionally popular amongst early modern Catholic readers. In my research, I have found that the accounts in the Flos sanctorum depicted a saint's pious conduct through their refutation of heresy as well as their imitation of contemporaries and previous exemplars. The duplication of others' behaviour resulted in cycles of piety associated with saints, which in turn gained legitimacy through their association with the apostolic church. In some cases, the Memoria Ecclesiae 24 (2004): 446-49. 
historical projection to include the early church established a genealogy of piety. Hagiography, as an expression of sacred history, provided legitimacy to these lineages of sanctity. I also believe that reading played an exceptional role in the formation of confession-specific behaviour through a process called observational emulation. Readers viewing the pages of the Flos sanctorum became witnesses to a saint's virtues, akin to a person being in the presence of a holy person. For instance, Thomas Aquinas observed the lives of the Desert Fathers through reading John Cassian's Conferences. Dominic as the founder of Aquinas's religious order had done the same thing, indicative of a practice imitated by Thomas. At the same time, Aquinas was a spectator of piety through the interaction with his peer, Bonaventure. This practice first emerged in the apostolic church, evident in John the Evangelist who not only wrote the life of Christ but also was present during Christ's ministries.

While neglected in the scholarship, hagiography provides insight into the cultural life of early modern Europe. For Simon Ditchfield, hagiography contains an ignored component of the histories of early modern science, religion, and polttics. This sentiment is partially due to the extant historiography's perception of saints' lives as a distinctly medieval entity with no continuity into the sixteenth-century and onwards. The exceptions to this trend are the works on early modern hagiography by Ditchfield, Alison Knowles Frazier, and David Collins. ${ }^{4}$ Ribadeneyra's Flos sanctorum scarcely appears in

${ }^{4}$ Simon Ditchfield, "Thınkıng with the Saints. Sanctity and Society in the Early Modern World," Critical Inquiry 35, no. 3 (Spring 2009) 554 "There is thus a sense in which hagiography-understood in the broader definition that encompasses canonisation trial iecords-is a substantially unwritten chapter in the histories of early modern science, politics, and even religion itself (since hagiography has been seen untıl relatively recently as preeminently a medieval genre) "Ditchfield is one exception to the tendency to envision hagiography as only a medieval collection of genres See also idem, Simon Ditchfield, Liturgy, Sanctity, and History in Tridentıne Italy (Cambridge Cambridge Unıversity Press, 1995), especially 17. 134, Idem, "Historia magistra sanctitatıs?' The Relationship between Historiography and Hagiography in Italy after the Council of Trent (1564-1742 ca )," Studies in Medieval and Renalssance History 3, ${ }^{\text {rd }}$ series 
the historiography of early modern Catholicism or Spain. Mentions to Ribadeneyra are few and tend to list him as a precursor to the Bollandists. Starting in the early seventeenth century, the Bollandists quickly dwarfed Ribadeneyra's hagiographical efforts through their monumental enterprise. ${ }^{5}$ Despite this eclipse, Ribadeneyra's Flos sanctorum was an incredibly popular work. This popularity demonstrates the continued interest in devotional literature amongst Catholics. ${ }^{6}$ It also reveals an unexpected affirmation of Catholic identity in the face of the Protestant onslaught on one of the traditional pillars of Christianity: saintliness and the nature of the sacred. Yet compilations of saints' lives had a multitude of functions, they were calendars, behavioural handbooks, and historical narratives targeted to the broadest possible readership. ${ }^{7}$ Meanwhile, the study of early modern life-writing has expanded to include fruitful discussions on the lives of Protestant reformers, present in the work of Irena Backus, James Michael Weiss, and Robert Kolb. ${ }^{8}$

This expansion, however, has not included the study of early modern Spanish or Catholic hagiography. While the association between life-writing and confessionbuilding has been made, this area of investigation also largely excludes early modern Spain and Catholicism. Themes and approaches evident in the historiography of lifewriting amongst Protestant confessions appear infrequently in discussions of early modern Catholicism or Spain. Notable exceptions to this tendency include the scholarship

(2006): 159-84; Alison Knowles Frazier, Possible Lives: Authors and Saints in Renaissance Italy (New York: Columbia University Press, 2005); David J. Collins, Reformed Saints: Saints' Lives and their Authors in Germany, 1470-1530 (New York: Oxford University Press, 2008).

${ }^{5}$ On the Bollandists, see David Knowles, Great Historical Enterprises (London: Nelson, 1963), 132.

${ }^{6}$ Lance Lazar, "The Formation of the Pious Soul: Transalpine Demand for Jesuit Devotional Texts, 1548-1615," in Confessionalization in Europe, 1555-1700, eds. John M. Headley, Hans Hillerbrand, and Anthony J. Papalas (Aldershot: Ashgate, 2004), 306-8.

${ }^{7}$ Ditchfield, Liturgy, 117-34.

${ }^{8}$ Irena Dorota Backus, Life-Writing in Reformation Europe (Aldershot: Ashgate, 2008); Robert Kolb, For All the Saints: Changing Perceptions of Martyrdom and Sainthood in the Lutheran Reformation (Macon, GA: Mercer University Press, 1987); James Michael Wiess, "Luther and His Colleagues on the Lives of Saints," Harvard Library Bulletin 33, 2 (1985): 174-95. 
of Jodi Bilinkoff and Federico Palomo. ${ }^{9}$ I hope that my thesis contributes to this

underexplored field in early modern history.

For the purposes of comparison, two other compilers of Flos sanctorum printed in the vicinity of Madrid and Alcalá will also feature in this study: the Hieronymite Pedro de la Vega (1478-1541) and Ribadeneyra's contemporary, Alonso de Villegas y Selvago (1534-1615). ${ }^{10}$ Prior to Ribadeneyra's compilation, the Jesuit college in Madrid had collaborated with Villegas to print his Flos. ${ }^{11}$ The hagiographical basis of this exploration in early modern Madrid, however, will be the 1599, 1601, 1604, and 1609 editions of

${ }^{9}$ Jodi Bilinkoff, "The Many 'Lives' of Pedro de Ribadeneyra," Renaissance Quarterly 52, no. 1 (Spring 1999): 180-96; idem, Related Lives: Confessors and Their Female Penitents, 1450-1750 (Ithaca, NY: Cornell University Press, 2005); Federico Palomo, "Corregir letras para unir espíritus. Los jesuitas y las cartas edificantes en el Portugal del siglo XVI," Cuadernos de Historia Moderna. Anjeos 4 (2005): 57 81 .

${ }^{10}$ DHEE s.v. R.M. Hornedo "Villegas, Alonso de"; OCSL s.v. "Villegas, Alonso de"; Aragüés Aldaz, "Tendencias y realizaciones," 512-13; Billy Bussell Thompson and John Walsh, "Old Spanish Manuscripts of Prose Lives of the Saints and their Affiliation. I: Compilation A (Gran Flos sanctorum)," La Corónica 15, no. 1 (1986-87): 20; José Martínez de la Escalera, "Casiano, el Cerratense y Pedro de la Vega OSH," Hispania sacra 47, no. 96 (1995): 692 n. 27. Every Flos sanctorum printed in Spanish after 1500 features in Appendix 1: Printed Flos sanctorum in Early Modern Spain. Pedro de la Vega was a Hieronymite prior, originally from Burgos, who compiled the Flos and a chronicle of the Hieronymites. Villegas was a hagiographer of equal stature to Ribadeneyra and both originated from Toledo. While Ribadeneyra was member of a religious order, Villegas was a lay hagiographer.

Various printers produced editions of Vega's Flos sanctorum between 1516 and 1580. I will use two editions in this study. The first is the complete collection: Pedro de la Vega, Flos sanctorum: la vida de nuestro señor Jesu Christo y de su sanctissima madre y de los otros santos segun la orden de sus fiestas, rev. Martin de Lillio (Alcalá de Henares: Juan Brocar, 1558). The second only contains the front-matter and the life of Christ: Pedro de la Vega, Flos sanctorum: la vida de nuestro señor Jesu Christo y de su sanctissima madre y de los otros santos segun la orden de sus fiestas, rev. Martin de Lillio (Alcalá de Henares: Andrés de Angulo, 1572). Both are revisions by the Franciscan Martín Lillio, who reportedly 'corrected' any of the heterodox components in the text.

Villegas's collection began production the same year of Vega's final printing. The work appeared in five volumes throughout Spain between 1580 and 1603. I mostly use the first Madrileño edition of 1588 : Alonso de Villegas y Selvago. Flos sanctorum y historia general, de la vida y hechos de Jesu Christo, Dios $y$ señor nuestro, $y$ de todos los santos de que reza y haze fiesta la iglesia catholica conforme al brevario romano, reformado por decreto del sancto concilio Tridentino, junto con las vidas de los sanctos proprios de Espana, $y$ de otros extravagantes (Madrid: Pedro Madrigal, 1588). On occassion, I also consult the second part of Villegas's Flos, which has the lives of only biblical saints: Flos Sanctorum: segunda parte: y historia general en que se escrive la vida de la Virgen Sacratissima Madre de Dios, y Señora Nuestra y las de los santos antiguos que fueron antes de la venida de nuestro salvador al mundo (Alcalá de Henares: Andrés Sánchez de Ezpeleta, 1609).

${ }^{11}$ Villegas, Flos (1588), 1v. The colophon reads: "Fecha este Colegio de la Compañia de Jesus de Madrid, á diez y ocho de Julio, de 1579." The earliest Jesuit college in Madrid proper had existed since 1570. The Colegio imperial de Madrid was a later Jesuit-run institution founded by Philip IV in 1629. Please see Gerónimo de Quintana, La historia del origen, antiguedad, nobleza y grandeza de Madrid (Madrid: Imprenta Real, 1629), 415r-416v. 
Ribadeneyra's Flos sanctorum. ${ }^{12}$ Ribadeneyra's other writings will be employed to augment the findings from the Flos sanctorum, in particular, his correspondence and treatises. $^{13}$

Villegas and Ribadeneyra belonged to the post-Tridentine hagiographical tradition started by Luigi Lippomano (1500-1559) and Laurentius Surius (1522/3-1578). ${ }^{14}$ While historians portray the Bollandists as the initiators of exhaustıvely researched and critical haglography, they also acknowledge the impact of Lippomano and Surius upon the collection of saints' lives. Both Surius and Lippomano accumulated sacred biographies that promoted a distinctly Catholic conception of the sacred. Lippomano used his compilation to promote Catholic doctrine at the expense of Protestantism. ${ }^{15}$ Surius, meanwhile, integrated miracle stories into his redaction to encourage Catholics to believe in saintly intercession. As well, he rehabilitated the unbelievable and exaggerated

12 Pedro de Ribadeneyra, Flos sanctorum, o libro de las vidas de los santos (Madrid. Luis Sánchez, 1599), ldem, Segunda parte del Flos sanctorum, o Libro de las vidas de los santos (Madrid. Luis Sánchez, 1601), tdem, Flos sanctorum, o, Libro de las vidas de los Santos, en el qual se contienen las vidas de Christo nuestro Señor y de su santissima madre, y de todos los Santos de que reza la Iglesia Romana (Madrıd: Luis Sánchez, 1604), idem, Segunda parte del Flos sanctorum, o llbro de las vidas de los santos (Madrıd Luıs Sánchez, 1609) Eventually incorporated 1nto the 1609 editıon was a companıon volume idem, Libro de vidas de santos que communmente llaman Extravagantes (Madrıd: Luis Sánchez, 1604)

13 Pedro de Ribadeneyra, Confessiones, epistolae, alıaque scripta inedita, 2 vols, ed. Daniel Restrepo (Madrid: La editorial Ibérıca, 1920-1923), MHSI 58 and 60 Other works by Rıbadeneyra that I cite include Pedro de Ribadeneyra, Histona ecclesiastica del scisma del Reyno de Inglaterra (Antwerp: Christopher Plantın, 1588); idem, Tratado de la tribulacion (Alcalá. Juan Iñıguez de Lequerıca, 1593); ıdem, Tratado de la religion y virtudes que deue tener el Principe Christiano (Madrid Pedro Madrigal, 1595).

14 I could not consult the early modern edition of Surıus, intead I used Laurentius Surius, Historlae seu vitae sanctorum juxta optimam coloniensem editionem, 13 vols (Turın Marietto, 1875-80) I will not focus on Lippomano extensively, but I do consult the three volumes of his compilations of saints' lives Luigı Lippomano, Sanctorum priscorum partum vitae numero centum sexagintatres, per gravissimos et probatissimos auctores conscriptae (Venice. Segno della Speranza, 1551), idem, Secundus tomus vitarum Sanctorum priscorum partum vitae numero ducentum et vigintiquinque, per gravissimos et probatissimos auctores conscriptae (Ven1ce. Segno della Speranza, 1553), idem, Vitarum sanctorum priscorum patrum per gravssimos auctores conscriptarum (Venice Segno della Speranza, 1554)

${ }^{15}$ The following is a useful biography of Lippomano's life found in a collection of documents when Lippomano was the Papal Nuncio to Poland Henricus Damianus Wojtyska, "Introductio," in Acta nuntiaturae Polonae 3, 1, Aloisius Lippomano (1555-1557), ed Henricus Damianus Wojtyska (Rome Institutum historicum polonicum Romae, 1993), 1-Xv11 
accounts in the Legenda aurea to rescue the legitımacy of saintly veneration ${ }^{16}$ Their texts transformed the genre of hagiography, yet maintained a sense of contınuity and tradition To better establish Ribadeneyra's place withın this traditıon, I will use Surıus and to a lesser extent, Lippomano as they had transitioned hagiography from its late medieval tendencies Surius and Lippomano went back to the sources to establish the veracity of a saint's existence ${ }^{17}$ Both Villegas and Rubadeneyra consulted the works of Surius and Lippomano in their compilations of saints' lives

Other early modern writıngs will illumınate Ribadeneyra's context, such as foundational texts by Ignatius of Loyola and the Jesuit pedagogical manual, the Ratio studiorum ${ }^{18}$ Every Jesuit, meanwhile, was familiar with the Sptritual Exercises and the Constitutions, respectively the guide to meditation and the order's governing document ${ }^{19}$

${ }^{16}$ There is a 1618 biography of Surius used for context "Vita reverendt eruditz religiost et de ecclesia opttme meritı Fr Laurentı Surı" in Laurentius Surius, Historiae seu vitae sanctorum (Turın Marietto, 1875) 2 I11-xi Surlus noted his relationship with Lippomano in a letter to Cardinal Gabriele Paleottı An abridged version of the letter appears here in "De ratıone hulus operis ac de historiarum sanctorum lectionis utılitate," in Surius, Historiae seu vitae sanctorum, 1 vil-xı

Surius wasted no time in discussing Lippomano What follows is the letter's first sentence "Ante annos non adeo multos, illustrissime Cardınalıs, vir ımmortalı memoria dignıs, Aloısıus Lipomanus, tum Veronensis Epıscopus, alıquot Tomos edidit de Vitıs Sanctorum sed confuse et absque certo ordine, quod el tum primum hoc opus multi et sudoris et temporis suscipient1, non ita facile et promptum esset in menses distribuere Vitas, quas ex diversis auctorıbus collegerat quamquam postea id in Simeone Metaphraste ab eo praestitum est" ( $1 \mathrm{vil}$ ) This letter has no date but a reasonable estimation is between 1572 to 1578 due to the reference of Gregory XIII (elected in 1572) at the letter's conclusion and Surius's death in 1578

${ }_{17}^{17}$ Aragues Aldaz, "Tendencias y realizaciones," 519-22, Ditchfield, Liturgy 124-26

18 "Ratıo atque instituto studlorum Societatis Iesu (1599)," in Ratıo atque institutıon studionum Soctetatis Iesu, ed Ladıslaus Lukacs (Rome Instıtutum Historıcum Societatıs Iesu, 1986) 355-454 MHSI 129 Earlier versions of the Ratio studiorum had existed since the $1580 \mathrm{~s}$

${ }^{19}$ Ignatıus of Loyola, Exercitıa Spirttualia eds Josephus Calverus and Candido de Dalmases (Rome Institutum Historicum Societatis Iesu, 1969) MHSI 100 I use the standard pagination for the four extant editions (Autographum, Versio vulgata, Versio prima a 1541, Versio prima a 1547) I use the Autographum, which is in Castilian, whereas the other editıons are in Latın

As for the Constitutions Ignatus of Loyola, Constitutiones Societatts Iesu (Rome Monumenta Historica Societatıs Iesu, 1936) MHSI 64 The text used is the Castilıan 1594 edition based on Ignatius's original handwritten document Whenever necessary, I have consulted the following transiation Ignatius of Loyola, The Constitutions of the Soclety of Jesus, trans Geolge G Ganss (St Louls Institute of Jesuit Sources, 1970) 
The Regulae also provided guidance for Jesuits, but was not a traditional religious rule ${ }^{20}$ Jesuits also attempted to imıtate the life of Ignatıus, the Society's founder and guidıng light, through reading works attributed to him that circulated in manuscript ${ }^{21}$ Ribadeneyra's Vita Ignatı amalgamated and supplemented these texts into one printed volume ${ }^{22}$ Conciliar texts familiar to Jesuits contained the doctrine of Trent such as the Canons and Decrees of the Councll of Trent and the Catechism ${ }^{23}$ An additional catechism by Jesuit Peter Canısıus will localıse the doctrine preached by the Society of Jesus $^{24}$ As well, everyday devotional works familiar to Ribadeneyra are important to this study For instance, the Breviarlum Romanum (1569) was an abridgement of the necessary readings for devotion ${ }^{25}$ The Martyrologıum Romanum (1584) included not only martyrs but also a comprehensive list of saints venerated in Catholicism and their feast days 26

${ }^{20}$ Regulae Societatis Iesu (Tarragona Felipe Mey, 1583) Different permutations of the Regulae have appeared since 1545 and 1546 I chose Felipe Mey's edition since it was among the earliest printed Regulae in Spain (IB 10742-43, 10745-49) On the early publication history of the Regulae, see JeanFrançoıs Gilmont, Les ecrits spintuels des premiers Jesuttes (Rome Instıtutum Historicum Societatis Iesu, 1961), 82-87

${ }^{21}$ The Autobiography appears in "Acta Patris Ignatı scripta a Lud[ovico] Gonzalez de Camara 1553/1555," in Fontes narrative de S Ignatio de Loyola et de Societatis Tesu Inttus, eds Denis Fernandez Zapıco and Candıdo de Dalmases (Rome Monumenta Historica Societatıs Iesu, 1943), 1 323-507 MHSI 66

The Spirttual Diary is in Ignatius of Loyola, "Ephermeris S N Ignatı," in Constitutiones Societatis Iesu (Rome Gregorian Pontıfical Unıversity, 1934), 1 86-158 MHSI 63

There are twelve volumes of Ignatius's letters Ignatius of Loyola, Epistolae et instructiones, 12 vols (Madrid Gabriel Lopez del Horno, 1903-11) MHSI 22, 26, 28, 29, 31, 33, 34, 36, 37, 39, 40, and 42

${ }^{22}$ I will use a modern edition of his life of Ignatıus Pedro de Ribadeneyra, Vita Ignatı Loyolae, ed Candido de Dalmases (Rome Monumenta Historica Societatıs Iesu, 1965) MHSI 93

${ }^{23}$ Canons and Decrees of the Councll of Trent, trans H J Schroeder (St Louls and London Herder Book Co , 1941), Catechism of the Council of Trent, trans J Donovan (Dublin W Folds and Son, 1829)

${ }^{24}$ Peter Canisius, Opus catechistlcum (Cologne Gervinus Calenıus and descendents of Johann Quentelius, 1577)

${ }^{25}$ Breviarium Romanum Editıo princeps (1568), eds M Sodi and A M Triacca (Vatican City Libreria editrice vatıcana, 1999) I have left out the Missale Romanum (1570) due to its considerable duplication of content from the Breviarum

${ }^{26}$ Martyrologium Romanum Editio princeps (1584), eds M Sodı and R Fusco (Vatıcan City Libreria editrice vaticana, 2005) 
I will not discuss every saint in the Flos sanctorum extensively because of the compilation's large number of saints' lives. ${ }^{27}$ In this thesis, we will limit ourselves to a detailed examination of twelve saints. The small number will facilitate the study of numerous overlapping developments in early modern Catholicism. Examples include the recollection of the apostolic church and the changes to medieval saints' cults. I have used the following criteria in deciding which saints to include in this thesis: saints relevant to early modern Spaniards, saints of the apostolic church, and saints that feature in Jesuit writings. The twelve examined saints do not fit all of these criteria, but represent a broad cross-section of early modern saintliness.

Saints that appeared prominently in Spanish religious life required inclusion in a compilation of sacred biographies printed in Madrid. The students Justus and Pastor were among the many patron saints of Madrid and Alcalá. They underwent martyrdom in Alcalá during Diocletian's Great Prosecution. ${ }^{28}$ Spaniards also prayed to Sebastian, another martyr under Diocletian and a popular intercessor in Spain against plague and pestilence. ${ }^{29}$ James the Apostle, meanwhile, was the patron saint of Spain and the Reconquista's figurehead, known as the Moor Slayer. ${ }^{30}$ These three saints had local, popular, and national cults in early modern Spain. Ribadeneyra was aware of these traditions of veneration, given that he operated out of Madrid.

Many early modern religious movements wished a return to the apostolic life featured in the New Testament and the Fathers. These saints are important since they

\footnotetext{
${ }^{27}$ The number of saints' lives in Flos sanctorum is inconsistent. On average, the redactions contain about two-hundred lives.

${ }^{28}$ This information is from the respective saints' lives found in Alban Butler, Butler's Lives of Saints, rev. ed., ed. Paul Burns, 12 vols. (Collegeville, MN: Burns \& Oates, 1995). For Justus and Pastor, see 8:42.

${ }^{29}$ Ibid. 1:132-33.

${ }^{30}$ Ibid. 7:196-98.
} 
were the original imitators of Christ. The saintliness of New Testament figures provided a template for all subsequent saints. I opted to use Peter as the first pope and the founder of the Roman Church, Paul as Christianity's pivotal theologian, John as both an apostle and an evangelist, as well as Stephen as a protomartyr. ${ }^{31}$ Other saints to consider are those that feature prominently in Jesuit writings appear as imitators of Christ or the apostolic church. Both Dominic and Francis of Assisi as founders of medieval religious orders exemplified the religious vocation for Ignatius and surface significantly in his Autobiography. ${ }^{32}$ The life of Christ inspired Dominic and Francis to their mendicant vocation. The Spiritual Exercises, meanwhile, mention Thomas Aquinas, Bonaventure, and Augustine for their contribution to theology. ${ }^{33}$ The mendicant saints are important due to the cycles of sanctity established between their founders and its recruits. While Thomas imitated Dominic's life, Bonaventure did the same with Francis, both perpetuating a mendicant religiosity. The continuity of sainthood within a religious order was important to the Society's efforts at integrating into Catholicism. Augustine's presence is essential since he founded a religious community without a rule and he too imitated the apostolic church.

This thesis investigates early modern religious identity expression through a textbased community, more specifically, through the publication of saints' lives. John O'Malley's vision of 'Early Modern Catholicism' encourages the historian to take into account the many faces of religious change in the early modern world. O'Malley argues that the changes in Catholicism are too broad to be confined to entrenched concepts such

\footnotetext{
${ }^{31}$ Ibid. $6: 224-34 ; 12: 204-6,210-12$.

${ }^{32}$ Ibid. 8: 55-66 (Dominic); 10:17-26 (Francis of Assisi).

${ }^{33}$ Ibid. 1: 194-200 (Thomas Aquinas); 7:111-14 (Bonaventure); 8: 279-88 (Augustine).
} 
as Counter-Reformation and Catholic Reformation ${ }^{34}$ While confessionalisation is an alluring explanation for the changes in early modern religion, it is not without its problems Confessionalisation, a concept popularısed by German historians, accounts for the ruptures in early modern Christendom through analyzing the process of confessionbulldng which occurred throughout Europe between the Peace of Augsburg (1555) and the Thirty Years' War (1618-1648). Explicit statements of doctrine, paired with the support of political rulers, defined these confessions, whether Calvinist, Lutheran, or Catholic ${ }^{35}$ For one, confessionalisation has a top-down partiality, focussing on the interactions of monarchs, reformers, and church leaders. Instead of explorations of the social dynamics of religion, quite often historians have preferred to examine the 'great men' of religious history.

Another problem with the confessionalisation thesis is its model-based reductionısm, which reveals an inability to depict the continuities between Christendom

${ }^{34}$ Growing out of the histonography in the nineteenth-century, historians of the CounterReformation and the Catholic Reformation based their interpretations on confessional and ideological lines Protestant historians used Counter-Reformation to suggest the church as a reactionary institution unable to reform itself without the provocation of the Protestant reformers Catholic historians countered with Catholic Reformation to describe a church workıng to reform religious life prior to Luther and contınuing the practice afterwards Hubert Jedin in the early twentieth century suggested that the Roman church experienced both simultaneously Jedin suggested that this perıod was a "Catholıc Reformation and/or Counter-Reformation' Please see Hubert Jedin, "Catholic Reformation or Counter Reformation?" in The Counter-Reformation The Essentıal Readings, ed David M Luebke (Malden, MA Blackwell, 1999), 19. 45

35 Wolfgang Reınhard, "Reformation, Counter-Reformation, and the Early Modern State An Assessment," Catholic Histortcal Review 75 (1989) 383-404 I use the reprint found in The CounterReformation The Essential Readıngs, ed. David M Luebke (Malden, MA Blackwell, 1999), 105-28

Ute Lotz-Heumann provides an excellent overview of confessionalisation's relationship with the historiography, see Ute Loz-Heumann, "Confessionalization," in Reformation and Early Modern Europe A Gulde to Research, ed. David M Whitford (Kırksville, MI. Truman State University, 2008), 136-157.

Localised discussions about Spanish confessionalisation can be found in Allyson M Poska, "Confessionalization and Social Discipline in the Iberian World," Archiv fur Reformationsgeschite 94 (2003). 308-19, Federico Palomo, "Disciplina christıana' Apuntes historiograficos en torno a la disciplina y el disciplinamiento social como categorías de la historia religiosa de la alta edad moderna," Cuadernos de Historia Moderna 18 (1997) 119-36

Helpful studies on early modern confessionalisation in France and Germany include Philip Benedict, "Confessionalization in France? Critical Reflections and New Evidence," in The Fatth and Fortunes of France $s$ Huguenots 1600-1685 (Aldershot Ashgate, 2001), 309-26; R Po-Chia Hsia, Social Discipline in the Reformation, Central Europe 1550-1750 (London and New York Routledge, 2002) 
and confessions. Instead of investigating the differences between confessions, the confessionalization thesis encourages the study of different religious entities as interchangeable groups depriving them of any distinction. ${ }^{36}$ The problems of focussing on the 'great men' and the reductionism are symptomatic of the 'strong theory of confessionalization'. The 'weak' version emphasises the rivalry between confessions and their formation of barricades around themselves. While the 'strong' overemphasises the similarities between confessions, the 'weak' fixates on differences exclusively. As O'Malley suggested, 'Early Modern Catholicism' complements the confessionalisation thesis rather than refutes it. O'Malley's notion enables the incorporation of popular religion, continuities in Christianity before and after the reformations, as well as accounting for the cultural detritus of twentieth-century historians of early modern religion. ${ }^{37}$ Moreover, Thomas Kaufmann's concept of 'confessional cultures' is useful since it explores how confessional churches contributed to the social and cultural life of its members. The idea of 'confessional cultures' also acknowledges the diversity of religious experience, instead of its uniformity, a problem which frequently plagued studies that adopted the confessionalisation thesis. ${ }^{38}$

Another legacy of the historiography is the assumption that Spanish clergy were either progressive humanists who embodied a protomodernity or small-minded scholastics who challenged the humanists. This generalization featured prominently in Marcel Bataillon's study of Erasmus's overarching influence in sixteenth-century

${ }^{36}$ Benedict, 311-13.

${ }^{37}$ John W. O'Malley, "Was Ignatius Loyola a Church Reformer? How to Look at Early Modern Catholicism," Catholic Historical Review 77, no. 2 (April 1991): 177-93. I use the reprint found in The Counter-Reformation: The Essential Readings, ed. David M. Luebke (Malden, MA: Blackwell, 1999), 6582.

\footnotetext{
${ }^{38}$ Lotz-Heumann, 144-45. Contrast with R. Hsia, 89-121.
} 
Spanish religiosity. Bataillon argues that the works of Erasmus galvanised early modern Spanish religion, creating a clergy that defined themselves according to their support or disapproval of Erasmus's ideas. ${ }^{39}$ The conception of the Spanish clergy as a monolithic entity oversimplifies and distorts the multifarious nature of priests in early modern Spain. As Lu Ann Homza has shown, clergy used whichever means they had at their disposal to make theological judgements and frequently lacked ideological consistency and drifted between tradition and innovation, Scholasticism and humanism. ${ }^{40}$ While Ribadeneyra was not directly part of this intellectual culture, its influence is evident in his diverse use of ancient, medieval, and contemporary sources. Thomistic Scholasticism was as important to Ribadeneyra as the humanist veneration of antiquity. Homza's conceptions are also suggestive of the clashes and contrasts in the reading habits of early modern Catholics.

Catholics forged an 'imagined community of readers' in this period involving readers and hearers of devotional texts. This concept draws upon Roger Chartier's notion of 'reading/interpretive communities', Brian Stock's 'textual communities', and Benedict Anderson's notion of 'imagined communities'. Anderson probes the role of print media in the development of national identities through the dispersal of vernacular texts. ${ }^{41}$ This idea can be nuanced to include Chartier's conception of assembled readers engaged in the

${ }^{39}$ Marcel Bataillon, Érasme et l'Espagne: Recherches sur l'histoire spirituelle du XVIe siecle (Paris: Droz 1937). I consulted the Spanish translation: idem, Erasmo y España: Estudios sobre la historia espirituel del siglo XVI, $2^{\text {nd }}$ ed. (México: Fondo de Cultura Económica, 1966).

${ }^{40}$ Lu Ann Homza, Religious Authority in the Spanish Renaissance (Baltimore and London: Johns Hopkins University Press, 2000). See also idem, "The Merits of Disruption and Tumult: New Scholarship on Religion and Spirituality in Spain during the Sixteenth Century," Archiv für Reformationsgeschite 100 (2009): 218-34.

${ }^{41}$ Benedict Anderson, Imagined Communities, rev. ed. (London and New York: Verso, 1983, reprint, 2006), 9-46. 
interpretation of texts. ${ }^{42}$ As well, Stock's notion of 'textual communities' explores the roles of individuals who have mastered a text and then use it to change a group's practices and beliefs. These texts acted as the pathways to religious perfection. The 'textual community' through its use of precedent and literacy caused conflict with the world that existed outside of the text, whether through reform or heresy. ${ }^{43}$ In much the same way that print media shaped national identities in the modern period, these communities of readers asserted a religious identity through their interaction with texts written in the specific languages of confessional discourse. Within this context of a nascent 'Early Modern Catholicism', the Flos sanctorum and other texts expressed Catholic identity after Trent. As such, these compilations are a useful tool with which to assess the transformation of Catholicism and sainthood after the Council of Trent.

The works of Michel de Certeau, Robert Darnton, Margit Frenk, and Fernando Bouza have informed my conceptions of reading and its place within communication networks. Certeau discusses the appropriation process of reading, akin to poaching or hunting for fragments of text. ${ }^{44}$ Darnton, meanwhile, focuses more on solitary and silent readers. He also refutes the traditional interpretation of early modern reading as a transition from intensive to extensive reading. In fact, he reveals how both coexisted in

${ }^{42}$ Roger Chartier, The Order of Books, trans. Lydia G. Cochrane (Stanford, CA: Stanford University Press, 1994), 1-23. The work of Roger Chartier is important to the history of reading. See also Roger Chartier, "Leisure and Sociability: Reading Aloud in Early Modern Europe," in Urban Life of the Renaissance, eds. Susan Zimmerman and Ronald F.E. Weissman (Newark, DE: University of Delaware Press, 1989), 103-20; idem, "Reading Matter and 'Popular' Reading: From the Renaissance to the Seventeenth Century," in A History of Reading in the West, eds. Guglielmo Cavallo and Roger Chartier (Amherst, MA: University of Massachusetts Press, 1999), 269-83.

${ }^{43}$ Brian Stock, The Implications of Literacy (Princeton: Princeton University Press, 1983), 88-240.

${ }^{44}$ Michel de Certeau, The Practice of Everyday Life, trans. Steven Rendall (Berkeley, CA: University of California Press, 1984), 165-76. 
eighteenth-century France. ${ }^{45}$ Frenk explores the auditory component of reading. Reading is a diverse practice, done alone, in silence, aloud, or in groups. The hearer of a text is an equal participant as the reader in communication cultures. ${ }^{46}$ Frenk's argument is particularly relevant when discussing the Jesuits due to the society's preoccupation with reading and preaching. Fernando Bouza combines the above approaches to explore how early modern Spaniards heard, saw, and read: these practices formed a hybrid means of dissemination and the acquisition of ideas and knowledge. ${ }^{47} \mathrm{An}$ example of how the Jesuits amalgamated reading and hearing can be found in the Sptritual Exerctses. The exercitant initially completed the examen (a spiritual review of the conscience) alone and meditated daily on religious things. The spiritual director dictated and gave orally to the exercitant daily exercises, relevant Bible passages, and other pious texts, such as saints' lives. That day's items provided the material for the exercitant's meditation. ${ }^{48}$ While the director did not read out the Spiritual Exerctses, it encouraged a communal identity through the appropriation of a text. As such, reading had the potential to influence Catholic conduct, a particularly important aspect of 'Early Modern Catholicism'. In the creation of early modern confessions, authorities became involved in the daily lives of people. An example of this social disciplining of Catholic reading habits was Inquisitional censorship of the book trade. Social discipline, however, emerged in devotional texts, such as catechisms, which provided the members of a confession with

${ }^{45}$ Robert Darnton, "First Steps towards a History of Reading" Australian Journal of French Studies 23 (1986). 5-30, reprinted in The Kiss of Lamourette Reflections on Cultural History (New York W.W Norton \& Company, 1990), 154-87.

${ }^{46}$ Margit Frenk, "Lectores y oidores La difusión oral de la literatura en el Siglo de Oro," in Actas del VII Congreso de la Asociación Internacional de Hispanistas (Rome. Bulzon1, 1982), 1 101-23

${ }^{47}$ Fernando Bouza, Communication, Knowledge, and Memory in Early Modern Spain, trans Sonıa López and Michael Agnew (Phıladelphıa Unıversity of Pennsylvanıa Press, 2004), 1-15

${ }^{48}$ Ignatius, Exercitta Sptritualia, [1-20] 
their doctrine and core beliefs. ${ }^{49}$ We will explore further early modern Catholic community by situating Ribadeneyra's lives of saints in the historiography of the Society of Jesus, hagiography, and communication networks.

The Society of Jesus developed the practice of writing their own histories approximately a half-century after their foundation in 1540. Even into the twentiethcentury, histories of the order did not deviate from this sixteenth-century model. For the most part, such works consisted of biographies of pivotal Jesuits and institutional accounts of the order, whether from its inception to the present or in a specific locale. ${ }^{50}$ Examinations of Jesult cultural life, such as their involvement in early modern sciences, art, and spirituality, lacked rigour and had a notorious tendency to list names and little else. ${ }^{51}$ One exception in the history of Jesuit spirituality was the work of Pedro de Leturia in the mid-twentieth century, which analysed Ignatian spirituality within the cultural milieu of the period. Most relevant to this study is his examination of the influence of the Desert Fathers on Ignatius and the role of ascetic and mystical literature in Jesuit contemplation. $^{52}$

Recently, historians of the Society of Jesus have become increasingly interested in Jesuits' contributions to early modern religious cultures. In the process, historians of the Society consider the plurality of their experiences, whether international missions, visual

${ }^{49}$ O'Malley, "Ignatius Loyola," 73-80, Reınhard, 110-17.

${ }^{50}$ An example of twentieth-century historical biographies is Willam V Bangert, Jerome Nadal, SJ, 1507-1580 Tracking the First Generation of Jesuits (Chicago. Loyola University Press, 2002) Two institutional histories include Antonio Astrain, who focuses exclusively on Spain, and William Bangert, who creates a history of the order from its beginnings to Bangert's era Antonio Astrain, Historia de la Compañía de Jesús en la asistencia de España, ${ }^{\text {nd }}$ ed., 7 vols (Madrıd Razón y Fe, 1912-1925); Willıam V Bangert, A History of the Society of Jesus (St Louls Institute of Jesuit Sources, 1972)

${ }^{51}$ John O'Malley, "The Historiography of the Society of Jesus," in The Jesutts Cultures, Sciences, and the Arts, 1540-1773, eds John W O'Malley et al. (Toronto: University of Toronto Press, 1999), 4-18

52 Pedro de Leturia, Estudios Ignacıanos, ed. Ignacio Ipanaguirre, 2 vols (Rome Institutum historicum Societatıs Iesu, 1957), 1 96-111, 268-331 
culture, contributions to spirituality and political thought, or their involvement in communication networks ${ }^{53}$ The diversity of current Jesuit research is evident in the recent essay collections on Jesuit contributions to arts, cultures, and sciences ${ }^{54}$ I will explore a handful of themes related to the early modern Jesuits As this thesis is a study of early modern communication networks, I will discuss the Jesuit missions and its epistolary practices, its visual culture, its intellectual culture that promoted the printing of books, as well as the religious and pedagogical culture of the Jesuit colleges

While earlier institutional histories of the order had always considered Jesuit visual culture in a cursory manner, since the late-1990s, scholars have pard more attention to the Society's use of visuality to inspire devotion Two distinct themes underlie the current analysis of Jesuit visual culture The first examines the changes to European Christianity during the sixteenth-century and the use of visual media to encourage the laity to worship, to legitımıse Catholic practıces, and to teach Catholic doctrine While Calvinists destroyed images and Lutherans reluctantly used them for pedagogical aims, the Society employed images to encourage meditation and piety through first focusing on the external and then transitıonıng towards the internal ${ }^{55}$ Thus, Jesuit visual culture depicted the early Christian martyrs as embodiments of a church battling heresy, drew connections between heresy and the plague, and created a sense of

${ }^{53}$ O'Malley, "Historiography," 24-26, ldem, The First Jesults (Cambridge, MA and London Harvard University Press, 1993), Florence Hsia, Sojourners in a Strange Land Jesults and their Scientific Missions in Late Impenal China (Chicago University of Chicago Press, 2009), Robert Maryks, Saint Cicero and the Jesults (Aldershot Ashgate, 2008), idem, The Jesult Order as a Synagogue of Jews (Leiden Brill, 2010)

${ }_{54}$ The two essay collections in question are The Jesuits Cultures Sclences and the Arts 1540 1773, eds John W O'Malley et al (Toionto University of Toronto Press, 1999), The Jesutts II Cultures Sciences and the Arts 1540-1773, eds John W O'Malley et al (Toronto University of Toronto Press, 2006)

${ }^{55}$ Paul Nelles, "Seeıng and Writıng The Art of Observation in the Early Jesuit Missions," Intellectual History Review 20, no 3 (2010) 322-23 
grandeur for the faithful and imparted core Catholic beliefs. Key themes included a continued devotion to Mary, the Holy Family, and especially the saints. ${ }^{56}$ At the same time, this visual impulse extended beyond church frescos and architecture as the same sensations are important to reading books and many forms of religious engagement, such as a sermon or a religious play. ${ }^{57}$

The second theme in the current scholarship involves the Society's use of images is its role in the overseas missions. One instance of this phenomenon is the iconography of Francis Xavier, the Jesuit missionary par excellence. Representations of Xavier in books and paintings not only promoted the cult of Francis to the indigenous laity who attended Jesuit churches, but it provided an example for members of the Society to follow. ${ }^{58}$ Locality did not impede the Society due to its ability to assimilate indigenous practices. Dissimilar from other religious orders, the Society excelled at negotiating between European Catholicism and localised beliefs, whether in Japan, China, India, or the Americas. ${ }^{59}$ These tendencies whether in Europe or abroad enabled the Society to do their missionary work, even when they lacked knowledge of the area's indigenous languages. Images, akin to other pieces of material culture such as books, facilitated religious discourse, even if the intended audience had no knowledge of the language spoken to them.

${ }^{56}$ Gauvin Alexander Balley, Between Renatssance and Baroque Jesult Art in Rome, 1565-1610 (Toronto, Buffalo, London: Unıversity of Toronto Press, 2003); Christine M. Boeckl, "Plague Imagery as Metaphor for Heresy in Rubens' The Miracle of Saint Francts Xavier," Sixteenth Century Journal 27, no. 4 (1996): 979-95; Kirstin Noreen, "Ecclesıae mulitantis triumphi: Jesuit Iconography and the CounterReformation," Sixteenth Century Journal 29, no. 3 (1998): 689-715.

${ }^{57}$ Jeffrey Chipps Smith, Sensuous Worship Jesutts and the Art of the Early Catholic Reformation in Germany (Princeton and Oxford: Princeton University Press, 2002).

${ }_{58}^{58}$ Maria Cristına Osswald, "The Iconography and Cult of Francis Xavier, 1552-1640," Archivum Historicum Societatis Iesu 71, no. 142 (2002)·259-77.

${ }^{59}$ Gauvin Alexander Balley, Art on the Jesult Missions in Asıa and Latın Amenca, 1542-1773 (Toronto, Buffalo, and London: Unıversity of Toronto Press, 1999); Franço1s-Marc Gagnon, La conversion par l'ımage un aspect de la mission des Jésultes auprès des Indiens du Canada au XVIIe siècle (Montiéal. Bellarmın, 1975). 
The Jesuits, however, built their community on multımedia. Jesuits used various media in the creation of communication networks, especially as the Society expanded during Claudio Acquaviva's tenure as Superior-General (1585-1615). ${ }^{60}$ Letters played vital roles as they provided Provincial and Superior-Generals accounts of the events in a locality. Jesuits wrote and sent these letters, initially, quarter-annually, and after 1573, annually. Letters when collected and then printed or circulated in manuscript also functıoned as devotional works. Akin to saints' lives, letters of Jesuit missionaries operated akin to manuals for living the 1deal clerical life. Letters also embodied Jesuit communication networks that they formed in the early modern world. ${ }^{61}$ Just as letters relayed the news of a Jesuit mission, they also circulated within other locales to encourage other Jesuits.

Jesults took advantage of these epistolary-based communication networks to disseminate printed works as well. In turn, bookstores and printers involved themselves in the Society's culture of texts. Jesuit authors interacted with local printers to produce their books of catechism, biography, religious controversies, as well as revised and updated works of the Church Fathers. At the same time, they also made use of the order's communicative framework to disperse and promulgate texts to read. ${ }^{62}$ Jesuit communication networks overlapped with other early modern arrangements, such as the Society's involvement in client-patron relationships to have their works printed in the

${ }^{60}$ An excellent study on one of the Society's international missions, specifically India is. Ines G Županov, Missionary Tropics The Catholic Frontier in India (16 $6^{\text {th }}$ and $17^{\text {th }}$ Centuries) (Ann Arbor, MI. University of Michigan Press, 2005)

${ }^{61}$ Markus Friedrich, "Circulatıng and Compilıng the Litterae Annuae Towards a History of the Jesuit System of Communication," Archivum Historicum Societatıs Iesu 153, no 77 (2008) 3-39; Palomo, "Corregir letras," 57-81

${ }^{62}$ On the role of printers, see Bernabé Bartolomé Martínez, "Las librerías e imprentas de los Jesuitas, 1540-1767," Hispania Sacra 40 (1988) 315-88. On the books read and written by Jesuits, please see Domınıque Bertrand, "The Society of Jesus and the Church Fathers," in The Reception of the Church Fathers in the West, ed. Irena Dorota Backus (Leiden and Boston Brill, 1995), 2 889-950. See also Lazar 
seventeenth century. ${ }^{63}$ Texts established and made tangible the Society's cultural identity in the increasingly globalised early modern Catholic world.

History and life-writing existed as two other important components of Jesuit culture. While the Society's teaching of history had a definite humanist influence, evident in their use of Cicero and Vergil, the Jesuit historical orientation also influenced their missionary work. ${ }^{64}$ At the same time, lives of Jesuit leaders and missionaries travelled in the same communicative framework. ${ }^{65}$ Ribadeneyra wrote the lives of three SuperiorGenerals (Ignatius, Laínez, and Borgia), his own biography modelled on Augustine, and the life of a Toledan holy woman. ${ }^{66}$ Ribadeneyra was a life-writing Jesuit and a historian of the sacred through whom he inserted himself and his religious order into Catholic religious life. Ribadeneyra built upon Surius and Lippomano's rehabilitation of sacred biographies and, as they had, refuted heresy and affirmed Catholic doctrine through the lives of saints. Ribadeneyra's textual community encouraged reform of hagiography and the nature of sanctity in early modern Catholicism. While Villegas emerged from the same Surius-based tradition in hagiography, his impact failed to extend beyond Iberia. Ribadeneyra, meanwhile, composed a sacred history from antiquity to the present day through his saints' lives. His importance is significant as preliminary results show at least seventy-four translations of his Flos sanctorum across Europe in the seventeenth and eighteenth centuries. In the same period, Spanish printers produced at least eighteen

\footnotetext{
${ }^{63}$ Martha Baldwin, "Pious Ambition: Natural Philosophy and the Jesuit Quest for the Patronage of Printed Books in the Seventeenth Century," in Jesuit Science and the Republic of Letters, ed. Mordechai Feingold (Cambridge, MA, and London: MIT Press, 2003), 285-329.

${ }^{64}$ Paul Nelles, "Historia magistra antiquitatis: Cicero and Jesuit History Teaching," Renaissance Studies 13, no. 2 (1999): 130-172; idem, "Du savant au missionnaire: la doctrine, les mœurs et l'écriture de l'histoire chez les Jésuites." XVIIe siecle 237 (2007): 669-89; Kristine Louise Haugen, "A French Jesuit's Lectures on Vergil, 1582-1583: Jacques Sirmond between Literature, History, and Myth," Sixteenth Century Journal 30, no. 4 (1999): 967-85.

${ }^{65}$ Florence Hsia, 30-50.

${ }^{66}$ Bilinkoff, "Ribadeneyra," 181.
} 
editions. ${ }^{67} \mathrm{He}$ was the single antecedent to the Bollandists' hagiographical monolith through his sacred biographies. Ribadeneyra's life-writing suggested the existence of a communication network comprised of saints' lives circulating amongst early modern Catholics.

While biographies feature heavily in Jesuit spiritual life and communication networks, scholars have neglected hagiography. A major contributor to this problem is the embedded assumption of hagiographical 'evolution' from the amateur Legenda aurea to the professional and scientific Acta sanctorum of the Bollandists. ${ }^{68}$ The exceptions focus on hagiography in New France, in Italy, in Germany, and in Spain. ${ }^{69}$ While scholars traditionally have equated the lives of saints with hagiography, this conception required augmentation to "include biographical accounts of persons regarded as holy or exemplary in their own time, even if they were not formally canonized as saints.."70 Hagiography exists alongside broader trends in early modern life-writing.

${ }^{67} B C J, 6: 1737-40,1743-53$. I generated additional results through the Karlsruhe Virtual Catalog. Each separate volume printed counts as an edition. Sommervogel lists the following translations of Ribadeneyra's Flos sanctorum printed throughout the seventeenth century (the number of editions appears in brackets): Castilian (ten), Flemish, German, Portuguese, Latin, and English (one each), French (fortynine), Italian (nine). Sommervogel also notes the existence of Japanese (c. 1623) and Kaqchikel (c. 1619) editions. Kaqchikel is an indigenous Mesoamerican language part of the Mayan languages spoken by the eponymous people of central Guatemala. Herbert Rosweyde completed the Flemish translation of Ribadeneyra's Flos sanctorum. Rosweyde began the hagiographical project that became the Bollandists, under Jean Bolland. By the 1640s, Castilian Flos sanctorum expanded to a third volume evident in their subsequent publication in three folio or six quatro volumes. Single lives produced in France appeared briefly in the late 1610 s. In the eighteenth-century, meanwhile, I have found the following translations: Castilian (eight), Italian (ten), German (one), Flemish and French (two apiece).

${ }^{68}$ Ditchfield, "Thinking with the Saints," 560 . A refreshing aversion to this narrative is: Sherry L. Reames, The Legenda aurea: A Reexamination of Its Paradoxical History (Madison, WI, and London: University of Wisconsin Press, 1985).

${ }^{69}$ Aragüés Aldaz, "Tendencias y realizaciones,"; Julia Boss, "Writing a Relic: the Use of Hagiography in New France," in Colonial Saints: Discovering the Holy in Americas, 1500-1800, eds. Allan Greer and Jodi Bilinkoff (New York: Routledge, 2003), 211-34; Ditchfield, Liturgy; Teófanes Egido, "Hagiografia y estereotipos de santidad contrereformista," Cuadernos de Historia Moderna 25 (2000): 6185; Alan Greer, "Colonial Saints: Gender, Race, and Hagiography in New France," The William and Mary Quarterly 57, no. 2 (April 2000): 323-48; idem, Mohawk Saint: Catherine Tekakwitha and the Jesuits (Oxford: Oxford University Press, 2005).

${ }^{70}$ Bilinkoff, Related Lives, 3. 
Specifically, historians use the concept of 'lıfe-writıng' as an analytical tool for examining secular and religious lives, independent of confession At its simplest, lives are narratives that recall and celebrate the conduct of its piotagonist as well as relate the context to 1ts reader, and can be biographical or autobiogiaphical Amongst the varieties of bıographies, Rıbadeneyra's Flos sanctorum contınues medieval hagıographic traditions yet also echoes humanist collections of didactic lives The medieval practice also included the lives of beatı, beatified but not canonized persons, as well as depictions of pious contemporaries ${ }^{71}$ Protestants also turned to biography but instead of miracles and outwardly works, these lives focused on divine intervention and assistance, corresponding to theologies of grace and predestınation ${ }^{72}$ While early modern historians have neglected hagiography due to their perception of it as a relic of the Middle Ages, medieval conceptions of hagiography are useful to help contextualise the practice ${ }^{73}$ Hagiography as sacred biographies sought to convey the resonances shared between saints and Christ ${ }^{74}$ As well, saints in the hagiographies of late antiquity exemplified conduct that the texts' readers imitated ${ }^{75}$ These medieval ıdeas remained pertınent to the Society's practice of 'life-writıng'

${ }^{71}$ For instance, on the relation between the lives male confessors wrote about their female penitents and its implications on gender, see Bilnkoff, Related Llves Beatıfication was one part of the process of canonisation to ensure that the holy man or woman in question corresponded with Church's doctrine

${ }^{72}$ Thomas F Mayer and D R Woolf, "Introduction," in The Rhetorics of Life-Writing in Early Modern Europe, eds Thomas F Mayer and D R Woolf, 1-37 (Ann Arbor, MI University of Michigan Press, 1995), 10-16

${ }^{73}$ For example, the work of Fernando Baños Vallejo on saints' lıves in medıeval Spain was helpful to my understandings of the collections of genres, his more recent monograph builds upon his earlier research Fernando Baños Vallejo, La haglografía como genero literano en la Edad Media (Oviedo Departamento de Filologı Española, 1989), tdem, Las vidas de santos en la literatura medieval española (Madrid Edıciones del Laberinto, 2003)

${ }^{74}$ Thomas J Heffernan, Sacred Blography Saints and their Biographers in the Middle Ages (New York Oxford University Press, 1989), 6-18

${ }^{75}$ Peter Bıown, "The Saint as Exemplar in Late Antıquity," Representations 2 (1983) 1-25 A work that ties in these exemplars into early modern preaching is Jose Aragues Aldaz, Deus concionator 
The same concern is applicable to the matter of genre, since lives encompass not only biographies, but also autobiographies. ${ }^{76}$ There is a rich scholarly literature, especially from literary studies, on early modern religious autobiography and its involvement in the construction of the self and its negotiation of gender and religious identities. ${ }^{77}$ While identity formation is a discernible part of studies on autobiography, only Bilinkoff's Related Lives that focuses on the contribution of sacred biography to conceptions of community in the early modern Spain. In early modern England, Anne Dillon explores hagiography's role in religious identity expression through the English martyr Margaret Clitherow. ${ }^{78}$

Hagiography is also associated with the study of early modern writing of history. Following Michel de Certeau, individual or compilations of saints' lives are texts preoccupied with time, place, as well as the discourse of 'virtues'. Hagiography as form of history provides longevity and precedent for a community's behaviours and actions. At the same time, these texts suggest a network for their dispersal regardless of format. Hagiographies function to perpetuate a religious collective memory and universal past to maintain the existence of a Catholic community, especially when it fights against

Mundo predicado y retorica del exemplum en los Stglos de Oro (Amsterdam and Atlanta, GA: Rodopi, 1999).

${ }^{76}$ Jay Rubenstein, "Biography and Autobiography in the Middle Ages," in Writıng Medieval History, ed. Nancy Partner (London: Hodder, 2005), 22-41.

${ }^{77}$ One of the earlier studies is the essay collection. Autobiography in Early Modern Spain, eds. Nıcholas Spadaccinı and Jenaro Talens (Minneapolıs: Prısma Instıtute, 1988). Much of the recent literature focuses almost exclusıvely on Teresa of Ávila and gender identity as featured in her autobiography. On this topic, see Gillian W.T. Alhgren, Teresa of Avila and the Politics of Sanctity (Ithaca, NY. Cornell University Press, 1996); Alıson Weber, Teresa of Avila and the Rhetonc of Femintty (Princeton, NJ: Princeton University Press, 1990). On the study of gender through autobiography, an excellent piece 1s: Gaburella Zarr, "Gender and Religious Autobiography between the Reformation and the CounterReformation: Typologies and Examples," in Saints, Scholars, and Poltticians Gender as a Tool in Medieval Studies, eds. Mathılde van Dıjk and Renée Nip (Turnhout: Brepols, 2005), 227-40.

${ }^{78}$ Anne Dillon, The Construction of Martyrdom in the English Catholic Community, 1535-1603 (Aldershot· Ashgate, 2002) 
competing ideologies and virtue-based discourses found in other confessions. ${ }^{79}$ Saints' lives operate in the same sphere as works of history and liturgy, which sought to legitimise traditions and organıse time. ${ }^{80}$ Catholics saw such 'lives' as spiritually edifying works as well as histories, whether the saints' lives in Ribadeneyra's Flos sanctorum, or readings in the Breviary and the Martyrology.

Jesuits created and used communication networks to disperse texts to inspire piety and to offer religious instruction to Jesuits and lay Catholics alike. There has been a good deal of work, which explores the diffusion of books across regional and national boundaries. For instance, Clive Griffin investigates the transmission of Protestant ideas into Spain amongst French itinerant print-workers through Inquisitorial documentation. ${ }^{81}$ Scholars have also examined the Protestant Reformation and its relationship to nationalised print cultures. Yet they attempt to locate the underlying similarities and distinctions between a transnational religious phenomenon and its substantiation in local contexts. ${ }^{82}$ Distribution networks of texts included other media than print. As evident in the Society's use of handwritten as well as printed media, these networks overlapped and could share the same intermediaries. Yet they did not behave as co-dependents, since these epistolary cultures had existed long before the arrival of print. In his work on early

${ }^{79} \mathrm{Michel}$ de Certeau, The Writıng of History, trans Tom Conley (New York. Columbia University Press, 1988), 269-83, especially 272 "The Life of a Saint is inscribed within the life of a group, either a church or a community The text also implies a network of supports (oral transmission, manuscripts, or printed works) the Life of a Saint connects two apparently contrary movements It assures a distance with respects to origins (a long-established community is distınguished from its past through the deviation that the very representation of the past constitutes). But furthermore, its return to origins allows unity to be reestablıshed at a tıme when the group, through its development, runs the risk of being dispersed "

${ }^{80}$ See Ditchfield, Liturgy; idem, "Historia magistra sanctitatis?" Ditchfield notes the importance of seeing the considerable overlap between history and hagiography, a division ignored by nineteenthcentury historians

81 Clive Griffin, Journeymen-printers, Heresy, and the Inquisition in Sixteenth Century Spain (Oxford. Oxford University Press, 2005)

${ }^{82}$ See The Reformation and the Book, ed Jean-Françoıs Gilmont, trans Karın Maag (Aldershot Ashgate, 1998) 
modern Spain, Bouza investigates the persistence of handwritten communication cultures. ${ }^{83}$ Bouza explores the negotiation of media amongst early modern Spaniards, addressing print, written, and oral cultures. ${ }^{84}$ Another type of printed media, images, contributed to the spread of reformed and confessional ideologies and operated through oral cultures. ${ }^{85}$ The dissemination of books by printers and authors coexisted and employed other media networks to attract and to interact with readers.

Simultaneous to this process was the ordering of texts by authorities to create an ideal library for readers. Ecclesiastic authorities such as the Spanish Inquisition censored texts considered heretical to Catholic teaching. In fact, the Inquisition effectively controlled reading habits in early modern Spain. ${ }^{86}$ At the same time, there was a trend to fashion a "library without walls", a collection of accumulated texts meant for reading. ${ }^{87}$ An example of this library includes Conrad Gesner's accumulation of every Greek, Latin, and Hebrew text printed in his Bibliotheca universalis. ${ }^{88}$ While differing in purpose, the Jesuit Antonio Possevino's Bibliotheca selecta was a concatenation of what Catholics

${ }^{83}$ Fernando Bouza, Corre Manuscrito (Madrid: Marcial Pons, 2001).

${ }^{84}$ See Bouza, Communication, 1-15, 39-56.

${ }^{85}$ The work of Robert Scribner is important here, see Robert Scribner, "Oral Culture and the Diffusion of Reformation Ideas," History of European Ideas 5, no. 3 (1984): 237-56; idem, "Incombustible Luther: The Image of the Reformer in Early Modern Germany," Past and Present 110 (February 1986): 3868; idem, For the Sake of Simple Folk: Popular Propaganda for the German Reformation (New York: Oxford University Press, 1994).

${ }^{86}$ José Pardo Tomás, Ciencia y censura: la inquisición española y los libros cientificos en los siglos xvi y xvii (Madrid: Consejo Superior de Investigaciones Científicas, 1991); Virgilio Pinto Crespo, Inquisición y control ideológico en la España del siglo xvi (Madrid: Taurus, 1983). See also Index de l'Inquisition espagnole 1551, 1554, 1559, ed. J.M. de Bujanda (Sherbrooke, PQ and Geneva: Centre d'Études de la Renaissance and Librairie Droz, 1984); Index de l'Inquisition espagnole 1583, 1584, ed. J.M. de Bujanda (Sherbrooke and Geneva: Centre d'Études de la Renaissance and Librairie Droz, 1993).

${ }^{87}$ Chartier, Order of Books, 61-88.

${ }^{88}$ Paul Nelles, "Reading and Memory in the Universal Library: Conrad Gesner and the Renaissance Book," in Ars reminiscendi: Mind and Memory in Renaissance Culture, eds. Donald Beecher and Grant Williams (Toronto: Centre for Reformation and Renaissance Studies, 2009), 148-69. 
ought to read that corresponded with the Society's course of study. ${ }^{89}$ While distribution networks affected the availability of books, other structures affected the creation of libraries of permissible and forbidden texts.

Recent work on the history of reading provides some of book history's most innovative investigations. Earlier works on early modern Spanish reading practices focussed mostly on the reading of secular literature and assumed that only the educated ever read. ${ }^{90}$ Scholarship has moved towards finding the greater literacy amongst early modern Spaniards as well as their affinity for devotional literature, evident in Inquisitional records. ${ }^{91}$ The central underlying problem of the history of reading is the greater care spent on the content rather than the process of the practice. ${ }^{92}$ This problematic assumption is evident in histories of the book based solely on libraries and booksellers' inventories. Owners of books do not necessarily read them. In fact, people frequently borrow books or travel elsewhere to access them. ${ }^{93}$ At the same time, a persistent correlation made involves the assumption that people only read printed works, which is problematic due to the variety of early modern media, which incorporated

${ }^{89}$ Luigi Balsamo, "How to Doctor a Bibliography Antonı Possevino's Practice," in Church, Censorship, and Culture in Early Modern Italy, ed Giglıola Fragnito, trans Adrian Belton (Cambridge and New York: Cambridge Unıversity Press, 2004), 50-78

${ }^{90}$ Maxime Cheval1er, Lectura y lectores en la España de los stglos XVI y XVII (Madı1d Turner, 1976); Philippe Berger, Libro y lectura en la Valencia del Renacimiento, 2 vols (Valencia. Edicions Alfons el Magnànım, 1987) (1989): 65-96

${ }^{91}$ Sara T. Nalle, "Literacy and Culture in Early Modern Castıle," Past and Present 125, no. 1

${ }_{92}$ Robert Darnton, The Great Cat Massacre and Other Episodes in French Cultural History (New York Vintage Books, 1985), 222 "To pass from the what to the how of reading is a difficult step."

${ }^{93}$ Bouza discusses this in Communication, 57-71 See also Trevor J Dadson, Libros, lectores y lecturas Estudios sobre blbllotecas partıculares españolas del Siglo de Oro (Madrıd. Arco/Lıbros, 1998), Domınıque Julia, "Reading and the Counter-Reformation," in A History of Reading in the West, eds Guglielmo Cavallo and Roger Chartier, trans Lydia S Cochrane (Amherst, MA University of Massachusetts Press, 1999), 238-68 
reading practices of some kind. ${ }^{94}$ One solution to this dilemma is to examine the text as a visual artefact and explore how readers interacted with the text through investigating format, type, and illustrations. Another avenue for research involves the exploration of sites of reading and their appearance in culturally relevant contexts.

This study will examine the saints' lives in Ribadeneyra's Flos sanctorum, which provided narratives for early modern Catholics to assert a religious identity. Within this imagined religious community articulating confessional rectitude, I have found a hagiographical writer promulgating readers into participating in the observational emulation of the saints in the Flos sanctorum. In Ribadeneyra's conception, readers witnessed the piety featured in the text from which they appropriated the exemplary conduct of saints with the intent that they behaved as ideal Catholics. The social disciplining of Catholics through reading saints' lives also perpetuated another facet of confessional identity, namely the validity of the Roman church by illustrating its continuous existence from the apostolic age to the contemporary era. These outcomes are indicative of Ribadeneyra's participation in the Society's culture of saints who manifested in various ways. Ribadeneyra promoted these objectives through his own reading evident in the implied genealogy of texts that suggested the existence of continuities between his age and that of the apostolic church. Ribadeneyra not only imitated the saints he read within the texts, but also the ones who wrote the same works.

This thesis examines Ribadeneyra's transmission of a Catholic community through his Flos sanctorum in this midst of confessionalisation. How did hagiography

${ }^{94}$ Sara T. Nalle, "Printing and Reading Popular Religious Texts in Sixteenth-Century Spain," in Culture and the State in Spain: 1550-1850, eds.Tom Lewis and Francisco J. Sanchez (New York: Garland Publishing, 1999), 126-56; José Manuel Prieto Bernabé, Lecturas y lectores: La cultura del impreso en el Madrid del Siglo de Oro (1550-1650), 2 vols. (Merida: Editora Regional de Extremadura, 2004). 
assert Catholicism as a new confession while maintaining its sense of tradition? How did his version of the saints depict exemplary pious conduct for early modern Catholics? How did these cycles of sanctity gain longevity? What books did Ribadeneyra read in his promulgation of a confessional community of readers? Ribadeneyra not only had to distance himself from Protestant life-writers, but also had to situate himself within Catholicism's sacred history of which hagiography was part. In late-sixteenth century Spain, Ribadeneyra composed his Flos sanctorum in a place committed to the veneration of saints, to reading about their lives, and the refutation of any unorthodoxy. The first chapter examines the context that Ribadeneyra wrote his Flos sanctorum in early modern Madrid and Alcalá. While Ribadeneyra continued Lippomano and Surius's hagiographical tradition, Ribadeneyra's Flos sanctorum augmented his predecessors by incorporating liturgical reforms into his saints' lives. Ribadeneyra adjusted his Flos sanctorum so that it corresponded with Catholic practices apparent in the Gregorian calendar, the Roman Breviary, and the Roman Martyrology. Ribadeneyra concentrated his efforts on the entirety of Catholicism. Villegas and Ribadeneyra also included the lives of extravagantes in their Flos sanctorum. In particular, Ribadeneyra used the extravagantes for the promotion of local cults, beatified figures, as well as Jesuit exemplars. Ribadeneyra situated the Society within early modern Catholicism by integrating his order into hagiographies.

Chapter two explores Ribadeneyra's printed marginalia in the Flos sanctorum that reveal the books he read as a Catholic historian. Ribadeneyra also made his reading habits clear in the prologues to his Flos sanctorum as well as in his other writings. For Ribadeneyra, Lippomano and Surius had initiated a new approach to hagiography, which 
he actively continued. Ribadeneyra also acknowledged the influence of other contemporary sacred historians, such as Caesar Baronius and his Annales ecclesiastici. I found that Ribadeneyra constructed a Catholic community through reading about the confession's tradition and legitimate connections with the apostolic church.

The practices of seeing exemplary conduct was evident amongst early modern Jesuits. Francis Xavier's letters encouraged other Jesuits to become missionaries, while Ribadeneyra's Vita Ignatii provided the pivotal virtues for every Jesuit. The final chapter explores the culture of observational emulation found in the Society and its relationship with reading. Texts became especially important after Xavier and Ignatius's deaths, since their exemplary lives required observation through reading instead of simply seeing their conduct in person. The increased reliance on observational emulation through texts was also important in the Society's age of rapid expansion under Superior-General Acquaviva. The number of Jesuits made it impossible to observe exemplars in action. Other facets of visual cultures in the Society of Jesus appeared in its performance of religious drama, its commissioning of frescos depicting saints, and its highly ornate Baroque churches, especially the order's mother church in Rome, Il Gesù.

Ribadeneyra's composition of hagiographies is one facet of the Society's heavily visual culture. I have found that the composition of saints' lives, however, also enabled Ribadeneyra to integrate the order into Catholicism considering the Jesuits' relative recent appearance in early modern Christianity. He also adapted the genre to conform to the observational emulation in use by Jesuits.Ribadeneyra achieved this objective by following the practices of Lippomano and Surius. In the midst of the Council of Trent, Lippomano started the practice of gathering sacred biographies from their sources. Surius 
continued Lippomano's project but amended the work and removed any superfluous lives. Ribadeneyra began to write his life of Ignatius at approximately the same time that Surius worked on his hagiographical compilation. He also read Surius and Lippomano. Surius and Lippomano used their hagiographies as a proclamation of their Catholicism and as a refutation of Protestant heresy, something that resonated with Ribadeneyra. In his Flos sanctorum, Ribadeneyra situated himself within the Lippomano-Surius tradition of hagiography to continue an authentic compilation of glorified Catholic exemplars. To begin, we will explore who was Pedro de Ribadeneyra and how early modern Spain's cultures of religious books and hagiography influenced and impacted Ribadeneyra. 


\section{Figure 1: Political Map of Early Modern Spain}

Sources: J.H. Elliott, Imperial Spain, 1469-1716, new ed. (London: Penguin, 2002), 1617; DHEE s.v. 'Geografía Eclesiástica'; Helen Rawlings, Church, Religion, and Society in Early Modern Spain (Basingstoke: Palgrave, 2002), 60.

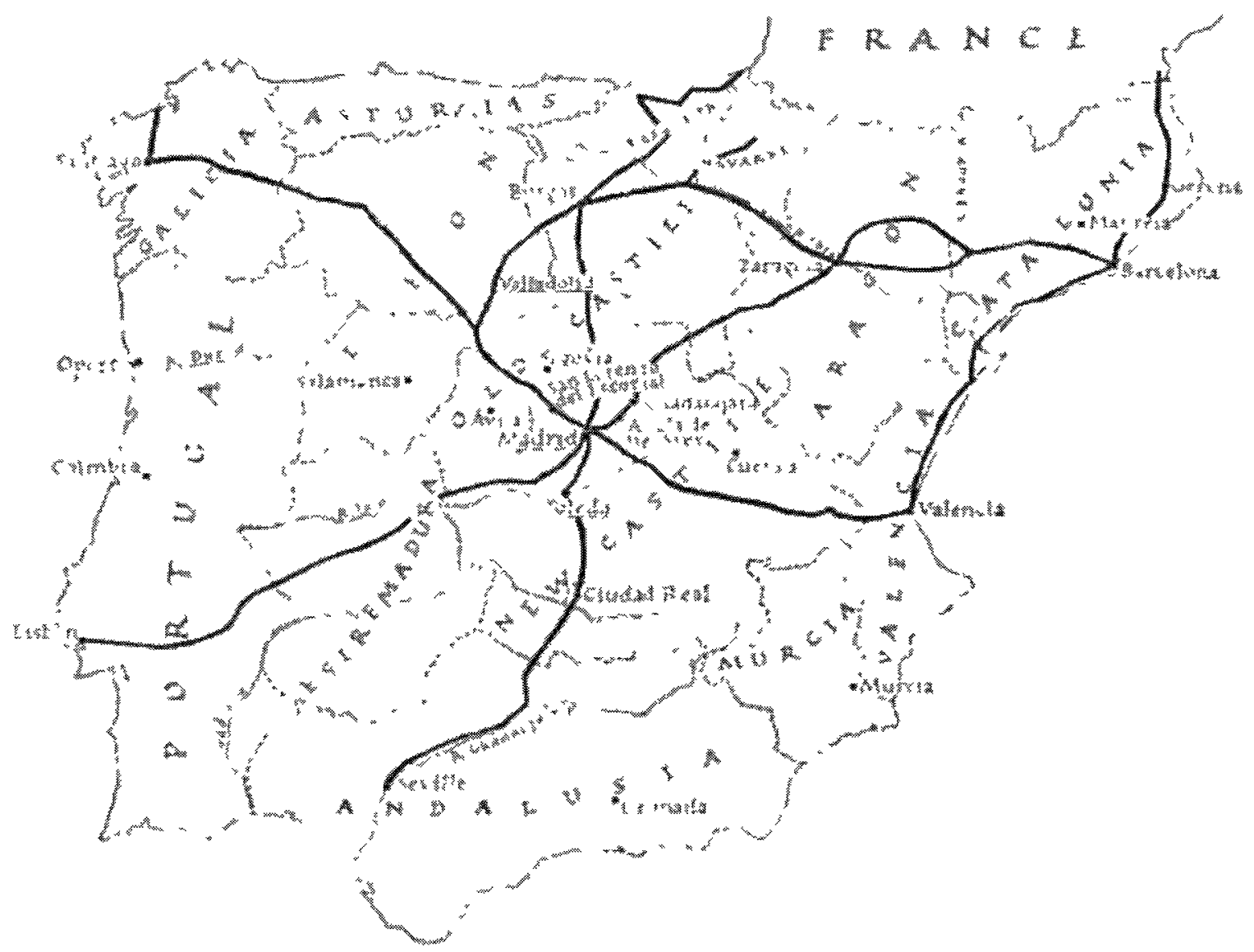

Black roads indicate the major routes in the sixteenth century.

Spain's ecclesiastic geography had eight provinces: Santiago, Burgos, Toledo, Seville, Granada, Valencia, Zaragoza, and Tarragona. The metropole of each province shared its name with the province. Each province was then divided into dioceses with the archdiocese housing the province's metropole. Toledo: All of New Castile and Murcia, most of Old Castile, north-eastern León (including Valladolid), Andalusia north of the Guadalquivir River, and western half of Asturias. Seat of the Primate of Spain. Santiago: Galicia, Estremadura, and the rest of León. Seville: The western half of Andalusia south of the Guadalquivir River. Granada: The eastern half of Andalusia south of the Guadalquivir River. Burgos: The eastern half of Asturias, northern Old Castile, the Basque Provinces, and Navarre. Zaragoza: Aragon and Ribagorza. Tarragona: Catalonia. Valencia: Valencia. 


\section{CHAPTER 1: RIBADENEYRA AND THE FLOS SANCTORUM}

Ribadeneyra was a writer of sacred biographies shaped by late medieval hagiographical tradition as well as its transformation during the sixteenth century. The changes to hagiographies were part of emergent confessional discourses in the later sixteenth century. His later life in Madrid was an interaction with early modern Spain's politics, its Catholicism, and its print culture. As well, his involvement in the Society of Jesus was also vital to understanding his work as a hagiographer and as an early modern Catholic, given that he spent seventy-one of his eighty-four years as a Jesuit. The aim of this chapter is to examine the context in which Ribadeneyra wrote and the way it influenced his contributions found in his hagiographical compilation, the Flos sanctorum.

Pedro Ortíz de Cisernos later renamed Pedro de Ribadeneyra, was born at the centre of Spanish religious life, Toledo. Ribadeneyra's father, Álvaro Husillo Ortíz de Cisneros, died in Ribadeneyra's youth. ${ }^{95}$ His mother Catalina de Villalobos had a close relationship with her only son that only increased after the death of Ribadeneyra's father. At a young age, he adopted the surname of his maternal grandmother, which derived from the town, Riba de Neira, in Galicia's Lugo province. Ribadeneyra's family were minor nobility in Toledo with access to the corridors of religious power in early modern Spain. Toledo was the metropole of the Archdiocese of Toledo, the seat of the Primate of Spain, a prestigious and powerful ecclesiastical office. The Archdiocese had authority over the majority of Castile and cities such as Madrid, Alcalá, Cuenca, and Valladolid

95 The subsequent biography of Ribadeneyra comes from numerous places: Bilinkoff, "Ribadeneyra," 180-83; DHEE s.v. Eusebio Rey "Ribadeneyra, Pedro de"; DHCJ s.v. M. Ruiz Jurado "Ribadeneira, Pedro de," 4: 3345-46; OCSL s.v. "Rivadeneyra, Pedro de". Specific episodes not mentioned in these accounts receive individual footnotes. 
(see Figure 1: Political Map of Early Modern Spain). If Valladolid and later Madrid were early modern Spain's political axes, Toledo was its sacred heart.

Due to Toledo's preeminent place within the Church, a multitude of ecclesiastical luminaries frequented the city. When Cardinal Alessandro Farnese the grandson of Pope Paul III visited Toledo in 1539, Ribadeneyra seized the occasion to make an impression on Farnese. While in the papal legate's palace where Farnese stayed, Ribadeneyra impersonated a palace page in order to get close to Farnese, since he wished to serve the cardinal. On the discovery of Ribadeneyra's gambit, Farnese offered Ribadeneyra passage to Rome as well as education there since the child's brazenness had impressed him. Once in Rome, Ribadeneyra received a top-rate education while working as Farnese's page. Ribadeneyra's life changed in 1540 , when he decided to abandon his position. Fearful of the consequences for his delinquency, he found asylum with Ignatius and his companions. ${ }^{96}$ At this time, Ignatius and others were in Rome petitioning Paul III to recognise the Society of Jesus. Drawn towards the Jesuit spiritual life, Ribadeneyra decided to stay with the Jesuits. Ignatius admitted him into the order shortly thereafter, although Ribadeneyra was only fourteen. The relationship between Ribadeneyra and Ignatius was close and continued until Ignatius's death in 1556.

As a Jesuit, there were four distinct periods in Ribadeneyra's life. The first was his time spent in Italy after his admission into the order. Until 1548, he travelled between Padua, Rome, and Venice. Though Rome was the administrative centre of the Society, Ribadeneyra was educated in Padua. ${ }^{97}$ In 1548 , he received an appointment in rhetoric at

\footnotetext{
${ }^{96}$ O'Malley, First, 36.

${ }^{97}$ Ribadneyra, Confessiones, 1:95-101.
} 
the Jesuit College in Palermo. ${ }^{98}$ By July 1553, Ribadeneyra was back in Rome where he stayed until $1555 .{ }^{99}$ In that year, Ignatius sent Ribadeneyra on a mission to the Spanish Netherlands and Cologne to elucidate the Society's rule the Constitutions to the Jesuit houses there. ${ }^{100}$ The year 1555 marked the next period of his life, spent mostly in the Low Countries. With the exception of time spent in England during the reigns of Mary I and Elizabeth I, Ribadeneyra continued to travel between Rome and the Spanish Netherlands until $1560 .^{101}$

As Ribadeneyra wandered across Europe, his reputation as a preacher increased. In 1560, Superior General Diego Laínez made Ribadeneyra the Provincial General of Tuscany, which initiated the third period in Ribadeneyra's career as a Jesuit: his return to Italy. During this time, Ribadeneyra travelled throughout northern Italy and to Rome. ${ }^{102}$ By October 1561, Laínez transferred Ribadeneyra to Sicily with a lengthy stopover in Naples. His time in Sicily lasted until 1565, when the order recalled him to Rome. ${ }^{103}$ His recall coincided with Laínez's death and Francis Borgia's appointment as SuperiorGeneral. He stayed in Rome from July 1565 to February $1566 .^{104}$ And until 1570 ,

${ }^{98}$ Ibid. 1:101-3. These letters dated from May 1551 to August 1552 confirm his presence in Palermo

${ }^{99}$ Ibid. 1:103-23.

${ }^{100}$ O'Malley, First, 336.

101 Ribadneyra, Confessiones, 1:123-336. According to his letters, between October 1555 and November 1556, he travelled between Brussels, Tournai, Flanders, Antwerp, and Ghent. By January 1557, he was in Florence. He then stayed in Rome between February and October of that year. In November, he was travelling back to Belgium when he posted a letter from Milan. He stayed in Brussels between December 1557 and July 1558. After which, he travelled to England, where he posted letters from London between December 1558 and February 1559. By April 1559, however, Ribadeneyra had returned to Brussels, where he stayed until May 1560.

102 Ibid. 1:336-419.

103 Ibid. 1: 419-597. At that time, he did not leave Sicily, but travelled between Palermo, Monreale, Messina, and Syracuse.

${ }^{104}$ Ibid. 1: 597-602. 
Ribadeneyra wandered between northern Italy and Rome. ${ }^{105}$ Soon after the election of the fourth Superior General Everard Mercurian, Ribadeneyra returned to Spain due to failing health. ${ }^{106}$ This move from Italy to Spain signalled the final period in his active life based in Spain. Between 1574 and 1577, Ribadeneyra traveled within Spain. ${ }^{107}$ After April 1577 , he remained in Toledo, with only a short trip to Jesús del Monte. ${ }^{108}$ Unhappy about his exile from Italy, he constantly petitioned Mercurian to return there; however, the order's officials ignored Ribadeneyra's requests. Ribadeneyra eventually moved to Madrid in 1583. Other than the occasional trip to Alcalá, he stayed in Madrid until his death in $1611 .^{109}$

The decision to stay in Madrid enabled Ribadeneyra's writing career to continue and to expand. This vocation began in the late 1560 s when General Francis Borgia commissioned Ribadeneyra to compose a life of Ignatius, as the Society required an official biography of their founder. At the same time, Borgia requested the removal of Ignatius's Autobiography from circulation since Borgia considered it inappropriate for popular consumption. The Autobiography had only circulated as a manuscript, with additions and corrections to it by Ignatius's scribe Luis Gonçalves da Câmara and the Society's administrative muscle, Jeronimo Nadal. ${ }^{10}$ While unspecified, Borgia's motivations might have been similar to Teresa of Ávila's desire to have the Discalced Carmelites' Rules and Constitutions printed. Borgia, akin to Teresa, could have disliked

\footnotetext{
${ }^{105}$ Ibid. 1:603-724. Places he travelled to include Florence, Siena, Brescia, Padua, Venice, Ferrara, Bologna, Modena, Parma, and Milan.

${ }^{106}$ There are no extant letters between 1570 and 1574.

${ }^{107}$ Ibid. 1: 724-56. He traveled between Barcelona, Madrid, Toledo (his hometown), Segovia, Seville, and Cordoba.

${ }^{108}$ Ibid. 1: 757-836, 2:14-38.

${ }^{109}$ Ibid. 2: 38-254. His correspondence declines in frequency after 1589 .

${ }^{110}$ DHSJ s.v. R. Ruiz Jurado, "Nadal, Jerónimo," 3: 2793-96; Gilmont, Écrits, 28-29; Ignatius, "Acta Patris Ignatii," 331-37.
} 
the fluidity of these circulating manuscripts as well as the arbitrary omissions and additions to these texts by well-intentioned members of the order. ${ }^{11}$ Ribadeneyra wrote to Nadal in 1567 to discuss the circulation of the Autobiography and the text's 1mperfections. While earlier in the year, he explained that his life of Ignatius followed Gonçalves's manuscript and any other writings about the Society's founder Ribadeneyra even celebrated the text's circulation. ${ }^{112}$ Later that year, however, Ribadeneyra noted that other Jesuits accumulated any relevant manuscripts of Ignatius's life to avoid any contradiction with published works, the divergences in the accounts stemmed from Ignatius's failing memory due to old age. ${ }^{113}$

By 1572, Ribadeneyra completed the life, the Vita Ignatı Lotolae Later, at the behest of General Acquav1va, Ribadeneyra revised and translated his biography of Ignatius, which appeared in Castilian in 1583 and remained in print subsequently. Ribadeneyra's life of Ignatius had seven Castilian and six Latin editions between 1572

${ }^{111}$ Bouza, Communicatıon, 33

${ }^{112}$ Pedro de Ribadeneyra, "To Jerónımo Nadal, Frascat, 29 June 1567," in Eplstolae Hieronym Nadal (Madrid. Augustıno Avrıal, 1902), 3 489-90 MHSI 21 "Agora estoy en Frascada para entender en lo que V R tanto dessea, que es en sciurr la uida de nuestro bendito $P$ Ignatio Hámelo mandado N P yo lo he aceptado muy de buena gana tengo gusto y inclınación á ello, aunque, por mı flaqueza de cabeça, me cuesta trabajo Confio en N S que se a de seruirdello, si me da salud y tiempo para ello, porque temo que passados estos dos meses auré de boluer á estar en Roma por la necessidad que los collegios tienen, aunque á mı pobre juızıo todo se auía de posponer á esto Scııo en latín mediano, sın affectatıón nı barbarıa Pienso scriurr 4 libros Scriuo esto á VR, primero por su consolación $2^{\circ}$, porque me ayude con sus oraciones, y de los collegios por donde passare $\mathrm{Y}$ sepa que las 12 missas que V R ha offrecido al scriptordesta obra me han anımado mucho y me anımará más saber que los otros Padres hazen lo mismo $3^{\circ}$, para que V.R me scriua particularmente lo que ha notado en los dichos y hechos de N P, y lo que le paresce que acerca desta historia se deue guardar, para que, ya que no está presente para endereçar y corregir lo que se haze, ayude en la ausencia con lo que se puede Lo $4^{\circ}$, para que V R procure de executar lo que ya N P ha mandado, y, á lo que creo, scritpo, á los prouınciales, etc, y es que reccojan buenamente lo que scriuió el P Luıs Gonçález, óqualquiera otro scripto de la uıda de N P, y lo tengan ellos y no permıtan que se lea, nı ande por las manos de los nuestros nı de otros, pues, siendo cosa imperfecta, no conuiene que estorueódesmınuya la fee de lo que más cumplidamente se scriue "

113 Pedro de Ribadeneyra, "To Jeronimo Nadal, Frascat1, 24 October 1567," in Eptstolae Hieronymı Nadal (Madrıd Augustıno Avrıal, 1902), 3540 "El recoger los scrıptos del P Luys Gonçales sobre la uıda de N P no nasció de mí, sino de estos Padres que lo acordaron á N P y á Su Paternidad le parescıó bien, porque publıcándose lo que se scriue, no paresciesse que ay diuersıdadó contradıçıon, ó esto no tuuiesse tanta auctorıdad como lo que se scriuó cası por boca de N P, el qual aunque en la substançıa fue fidelísımo, en los partıculares de algunas cosas es corto, y en la relaçıón de los tıempos ya á la postre de su uejez le faltaua la memoria" 
and $1611^{114} \mathrm{He}$ also wrote the lives of the subsequent Superıor Generals Laínez and Borgia Of the single lives, Borgia had two editıons, Laínez had an edition, while the compilation of Jesuit lives had two editions ${ }^{115}$ Between the first pinting of Ribadeneyra's Flos in 1599 and his death in 1611, the sacred biographies of Jesuits ceased to be printed as autonomous editions Instead, Ribadeneyra integrated them into the Flos sanctorum

In addition, Ribadeneyra also composed a biography of the Toledan laywoman Estefanía Manrique de Castilla and wrote his own autobiography modeled on Augustıne's Confessions These two texts, however, were never printed and circulated in manuscript ${ }^{116}$ Other works include a consolatory treatise for Spanıards after the defeat of the Armada, a refutation of Machiavellı's Prince, and an ecclesiastic history of the Englısh 'schism' 117 Ribadeneyra's complation of saints' lives, the Flos sanctorum, came at the very end of his career, first published in Madrid in 1599 Madrid-based printers produced most of the first editions of Ribadeneyra's works, including his Jesuit biographies Subsequently printers across the Iberian Penınsula produced editions of his works (see Figure 2 The Geography of Production of Ribadeneyra's Works)

${ }^{114}$ See Appendix 2, Printed Works of Pedro de Ribadeneyra BCJ, 6 1726, Gilmont, Ecrits 7, BM $191,211,246-47,457,498,524-25, I B$ 15842-45, 15860, 15867, 15874, TM 564, 618, 674, 712-13

${ }^{115} B M 394,457, I B 15857,15860,15865-67, T M 534,564,618$

${ }^{116}$ Bilinkoff, "Ribadeneyra," 181

${ }^{117}$ Michel de Certeau, Mystic Fable, 2 vols, trans Michael B Smith (Chicago University of Chıcago Press, 1992), 1 250-51, Gilmont, Ecrtts, 32-33, 38-39, 269-76, O'Malley, "Historıgraphy", 6-7 Rıbadeneyra's printed works feature in Appendix 2 


\section{Figure 2: The Geography of Production of Ribadeneyra's Works}

Figures taken from Appendix 2. Other print centres not featured on this map: Antwerp (6); Lyon (2); Ingolstadt (1) and Naples (1).

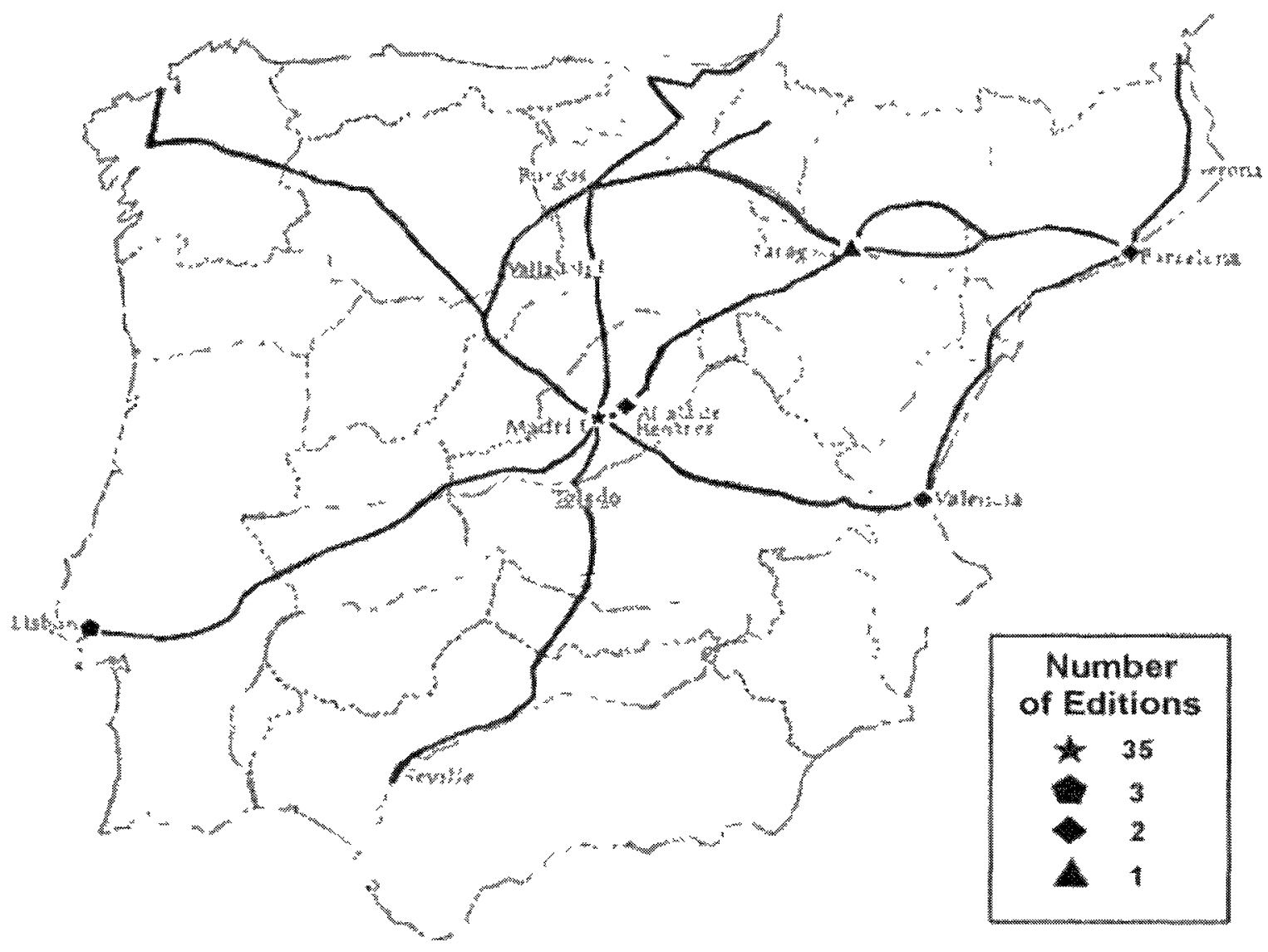

The collaboration of Madrileño printers with Ribadeneyra revealed the interconnectedness of early modern cultures of print and religion as well as their engagement with politics. The printer of Ribadeneyra's Flos sanctorum Luis Sánchez relied on the Spanish court and the hierarchical church for his business, evident in his setting up shop wherever Philip III installed the court, something that marks him as an establishment figure. By the late sixteenth century, the Sánchez printing house had become a fixture in Madrid. When the court moved to Valladolid in 1602, Sànchez established a press there as well though he did not cease print operations in Madrid. 
Luis's brother, Lucas, looked after affairs in Valladolid. Sánchez's Valladolid operations ended four years later when the court returned to Madrid. After Luis's death in 1627, control passed to his wife, Ana de Carasa (1627-1631), and then Luis and Ana's four children. ${ }^{118}$ Ribadeneyra, most likely, travelled in the same circles as Sánchez. His printing of Ribadeneyra's Flos suggests that the political and ecclesiastic elites approved of his approach to hagiography.

Ribadeneyra worked regularly with three Madrid printers: Alonso Gómez, Pedro Madrigal, and Luis Sánchez. After Ribadeneyra decided to remain in Madrid, Gómez printed Ribadeneyra's life of Ignatius and his Historia eclesiástica. While the affiliation between Gómez and Ribadeneyra ended in 1589, the previous year Ribadeneyra started a working relationship with Madrigal. The most prolific of Ribadeneyra's printers, Madrigal printed the Historia eclesiástica, the Tratado de la tribulación, the Tratado de la religión, the lives of Ignatius and Borgia, and even a collection of pre-1599 complete works. Madrigal's press also produced Villegas's Flos sanctorum in Madrid in 1588, 1589, 1592, 1593, and 1594. ${ }^{119}$ Madrigal's books were mostly Castilian, with the occasional Latin text in folio, octavo, and then quarto sizes. His output consisted of utilitarian works, a broad category including political decrees, educational manuals, as well as medical and legal texts. Ecclesiastic and devotional works especially ones by Jesuits held a prominent place within Madrigal's list. The number of devotional books printed was comparable to the volume of utilitarian works. ${ }^{120}$ Ecclesiastic texts included

118 Julián Martín Abad, La imprenta en Alcalá de Henares, 1502-1600, 2 vols. (Madrid: Arco/Libros, 1991), 1:117-18 ; TM, 24-25, 32-35, 41; DIE s.v. "Sánchez, Andrés", "Sánchez, Francisco", "Sánchez, Luis", "Sánchez, Luis (Ana de Carasa. Viuda de)", and "Sánchez, Luis (Ana de Carasa. Viuda de) [Heredera]".

${ }^{119}$ TM, 19-22, 28-31; DIE s.v. "Gómez, Alonso", "Madrigal, Pedro". Consult Appendix 1, under IB 19569, IB 19577, IB 19590, IB 19594, and IB19599

${ }^{120}$ Figures taken from Appendix 3, Books Printed by the Madrigal Print House of Madrid. 
Papal bulls, rules for religious orders, Council decrees, and theological treatises. Devotional works, meanwhile, were texts meant to encourage prayer, meditation, and religious fervor. Among these books were saints' lives, prayer manuals, and recollections from the lives of Christ and Mary.

Ribadeneyra and Madrigal's relationship ended in 1595. At that point, Ribadeneyra had paired up with Sánchez, who was responsible for the many editions of the Flos sanctorum, the Tratado de la religión, and a collection of all of Ribadeneyra's works. Sánchez constantly printed the Flos between 1599 and 1611; after production of the Flos's first and second parts in 1599 and 1601, it underwent additional print runs in 1604, 1609, and 1610. Even after Ribadeneyra's death in 1611, Sánchez continued to print works by Ribadeneyra.

While Sánchez and his dynasty printed an abundance of books in a variety of genres, religious texts predominated within his production. Most prevalent were devotional books, including saints' lives. In his pre-Valladolid era, the number of professional, ecclesiastic, and devotional works was almost equal. These books together constituted the majority of Sánchez's production. The Society of Jesus was the most represented order in Sánchez's operation at the time. The number of Castilian texts produced by Sánchez was double that of Latin ones. These tendencies continued even after Sánchez's operation diversified, when some of his printers again followed the court to Valladolid when Philip III moved it in 1602. The Valladolid branch of Sánchez's print house produced whatever the court required. As a result, most of what Sánchez printed in Valladolid was utilitarian and ecclesiastic works in Castilian. 
He also maintained a printing presence within Madrid, where he printed mostly Castilian devotional works in quarto-size, mostly by Jesuits and Mercedarians. The postValladolid period, meanwhile, continued the practices apparent at the onset of Sánchez's printing career. He produced few Latin works, instead issuing texts in the vernacular especially in larger formats: folio and quarto. While the majority of his production consisted of devotional and ecclesiastic texts, he printed works by members of various orders including the Jesuits, the Franciscans, and the Minims. ${ }^{121}$ Sánchez, however, contributed to the hagiographical culture of post-Tridentine Spain. He had printed Villegas's Life of Isidore (1592) and Lope de Vega's epic poem (1599) about the same holy man. ${ }^{122}$ Interestingly enough, the house of Madrigal printed the later editions of Lope de Vega's poem in 1602 and $1603 .{ }^{123}$

Ribadeneyra also had some interaction with the print culture of Alcalá, in particular, the printer Juan Iñiguez de Lequerica. Iñiguez issued a single edition each of the Tratado de la tribulación and the Historia eclesiástica in 1593. While Iñiguez was an active printer in Alcalá from 1570 to 1599, he also twice worked in Madrid (1583-4 and 1599). No Alcalá printer of this era printed an edition of Ribadeneyra's Flos. For Villegas, an edition printed by Andrés Sánchez de Ezpeleta (no relation to the previous Sánchez family) appeared in 1609. Andrés assumed control of his father's print-shop in 1607 after his father's death. Justo's wife and Andrés's mother, however, retained control of the print house until her death in $1609 .{ }^{124}$

\footnotetext{
${ }^{121}$ Figures taken from Appendix 4, Books Printed by the Sánchez House of Madrid.

${ }^{122} B M 398$ (Villegas) and 664 (Lope de Vega).

${ }^{123} B M 827$.

${ }^{124}$ Martín Abad, Alcalá (1502-1600), 1:127-33; TM, 31-32; DIE s.v. "Iñiguez de Lequerica, Juan", "Sánchez Crespo, Justo", "Sánchez Crespo, Justo (viuda de)", and "Sánchez de Ezpeleta, Andrés".
} 
Ribadeneyra was one of many hagiographers writing in early modern Spain. According to Raphaël Carrasco's figures and analysis, printing of hagiography between 1560 and 1629 increased constantly. This volume of hagiographies indicates the wide dissemination and demand for hagiographies in Spain. While Madrid printed eighty-three editions, the other cities produced less than a third of Madrid's amount: Barcelona (thirty), Seville (twenty-seven), Toledo (twenty-six), Valencia (twenty-five), Valladolid (twenty-three), and Salamanca (twenty-two). By way of comparison, Alcalá only produced eleven editions at that time. ${ }^{125}$ Behind Madrid, Barcelona printed the most hagiographies in Spain, followed by Seville, Toledo, Valencia, Valladolid, and Salamanca. The other centres when taken together have approximately double the output of Madrid. As evident in the production of hagiograhies, early modern Spain lacked a centralised print culture. In comparison, France had a centre of printing in Paris while Venice occupied a similar role in Italy. Interestingly, there is a noticeable variation in production levels when comparing print-runs in twenty-year durations. Returning to Carrasco's statistics, between 1560 and 1579 only twenty-five hagiographies appeared. Between 1580 and 1599 , production more than tripled to seventy-nine. Finally, between 1600 and 1619 , the number of first editions doubled to $161 .{ }^{126}$

Production of Flos reflected this general tendency of increased hagiographical book production. Earlier versions of the Flos sanctorum that predated Villegas and Ribadeneyra also had numerous editions. The most popular rendition compiled by the Hieronymite monks Gonzalo de Ocaña and Pedro de la Vega had nineteen print-runs

\footnotetext{
${ }^{125}$ Raphaël Carrasco, "Loin des enfers: littérature hagiographique et propagande dans l'Espagne classique (XVIe et XVIIe siècle)," in Enfers et damnations dans le monde hispanique et hispanoaméricain, eds. Jean-Paul Duviols and Annie Molinié-Bertrand (Paris: Presses universitaires de France, 1996), 380-81.

${ }^{126}$ Carrasco, 370.
} 
between 1516 and $1580 .^{127}$ The Flos was not a static text, but underwent perceived rehabilitation or revision by various theologians. The Franciscan Martín de Lillio revised the Flos of the Hieronymites Ocaña and Vega. One Zaragoza edition appeared on Spain's Index of Prohibited Books. ${ }^{128}$ Of these earlier Flos sanctorum, printers in Zaragoza, Barcelona, Alcalá, and Seville produced most of them, which were widely dispersed along the common sixteenth century routes for trading and for travelling. The volumes of hagiographies produced do not betray a predominant print-centre, since the editions ranged from one to ten throughout the sixteenth century (see

${ }^{127}$ Figures taken from Appendix 1.

${ }^{128}$ Index de 1551, 1554, 1559, 671; Index de 1583, 1584, 947. Both have the same entry: "Flos sanctorum, impresso en Zaragoça, año de 1556." While no Flos from that year or city exists in my findings, Bujanda points to a contemporary description of that Flos as "añadidas más de cincuenta hystorias que ningún otro [Flos sanctorum] ni en el de Zaragoza se pone" (Index de 1551, 1554, 1559, 599; Index de $1583,1584,480-81)$. 
Figure 3: Geography of Production of Castilian Flos Sanctorum not by Ribadeneyra or by Villegas). This tendency contrasts with the common assumption of increased centralisation in early modern Spain. Fragmentation was the norm and was apparent in Iberian print centres. 
Figure 3: Geography of Production of Castilian Flos Sanctorum not by Ribadeneyra or by Villegas

Figures taken from Appendix 1. For clarification purposes, Alcalá had six editions, whereas Seville had seven. The featured print-centre south-west of Valladolid is Medina del Campo.

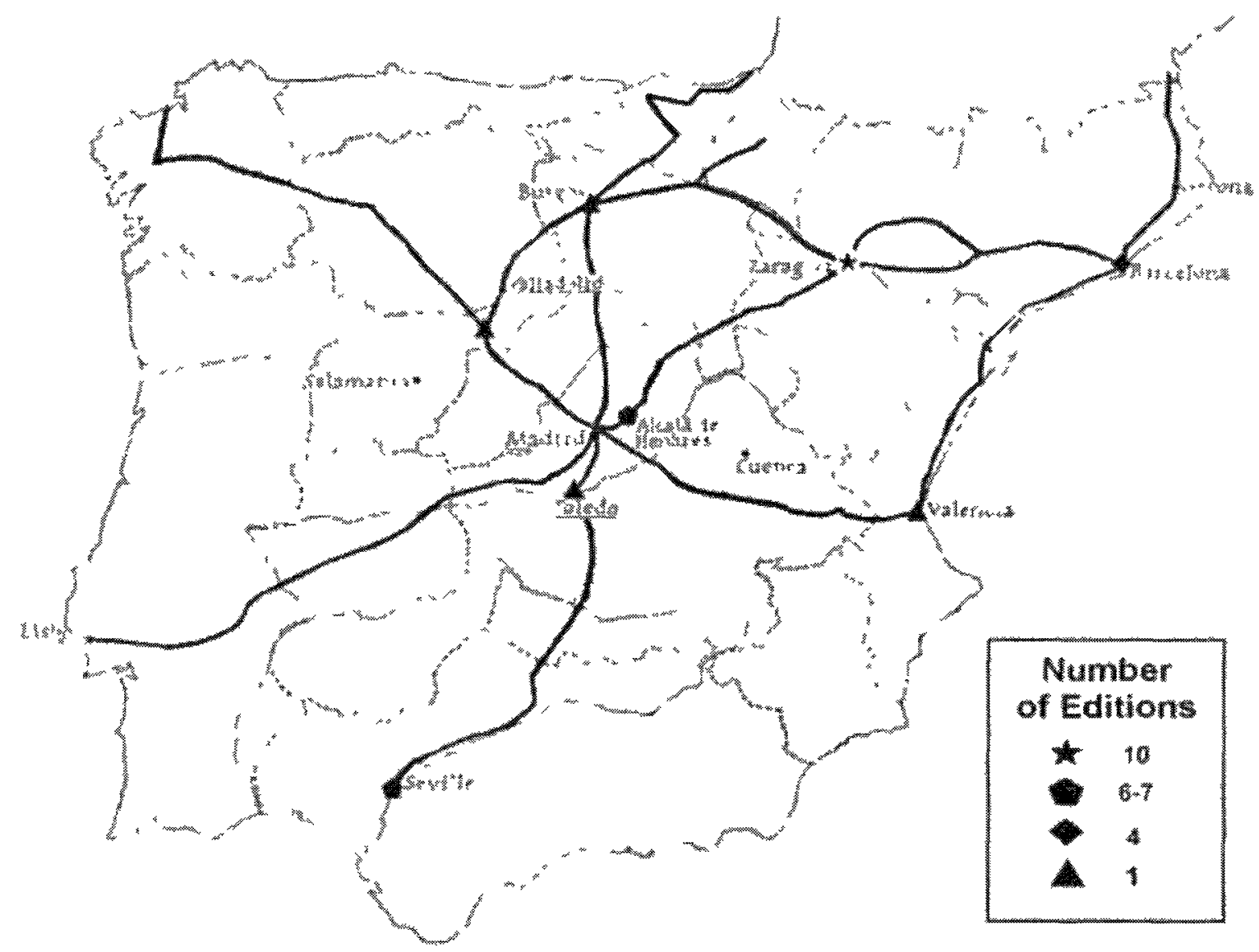


Figure 4: Geography of Production of Castilian Flos Sanctorum by Villegas and by Ribadeneyra

Figures taken from Appendix 1. For clarification purposes, those centres that produced five or less editions, their exact edition counts are Cuenca (5), Alcalá (2), and Huesca (1). Huesca is the print centre located northeast of Zaragoza.

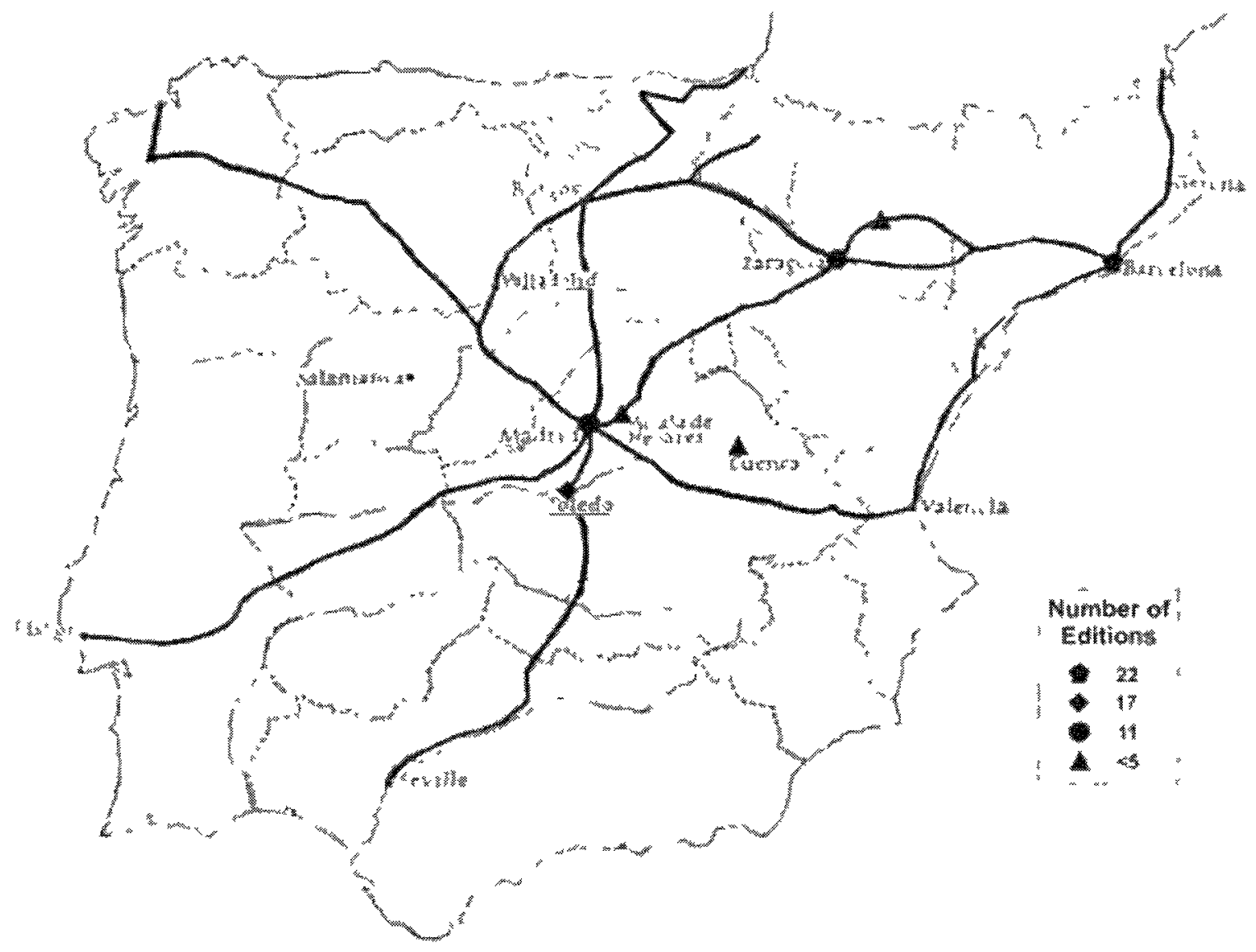

The first print-run of Ribadeneyra's Flos was in 1599, while Villegas' edition had appeared much earlier in 1580 . The work of both Ribadeneyra and Villegas was part of a movement towards the publication and the dissemination of saints' lives originating with Lippomano and Surius. The editions of Villegas and Ribadeneyra altered this course (see Error! Reference source not found.). Zaragoza and to a lesser extent Alcalá continued to print Flos sanctorum. Production expanded in Barcelona. Other print centres emerged 
as well including Cuenca, Toledo, and Madrid. When reviewing the geographies of production of Castilian Flos sanctorum, the print centres producing hagiographies became more centralised dependant on their associated kingdom and not on Madrid. Along with this development, there was also a noticeable trend in the formation of central and peripheral printers. For instance in the Crown of Castile, the producers of Flos sanctorum all work within New Castile. Madrid was the central print centre in Castile, while Cuenca, Alcalá, and Toledo were its tangential branches. At that time, Cuenca was a prosperous town due to its textile and agricultural enterprises. The Crown of Aragon, meanwhile, had printers in its most prominent cities: Zaragoza and Barcelona. The printers in an Aragonese university town, Huesca, were secondary producers of hagiographical texts. This trend reveals how Spanish printers began their consolidation of an industry and the means to disseminate religious texts such as the Flos sanctorum.

The Flos sanctorum was a popular compilation of saints' lives arranged according to the order of the liturgical calendar. Beginning in Lent, the Flos alternated between an episode in the life of Christ or Mary, a saint's life, the story of a community's acquisition of saintly relics, or the tale of a miraculous construction of a church, monastery, or cathedral. Different editions of the Flos sanctorum varied in length; for instance, Ribadeneyra's 1599 and 1601 compilation spanned approximately 1500 pages. Sixteenthcentury editions tended to feature woodcut illustrations, the quality of which varied. By the seventeenth century, however, the physical appearance of a Flos transformed. While Villegas's hagiographical collection continued to be image-intensive, Ribadeneyra's editions were without images. Yet Ribadeneyra did provide marginal citations of textual authorities (Figure 5 outlines the visual changes to the Flos sanctorum). 


\section{Figure 5: Various Flos Sanctorum}

Pedro de la Vega, Flos sanctorum: la vida de nuestro señor Jesu Christo y de su sanctissima madre y de los otros santos segun la orden de sus fiestas, rev. Martin de Lillio (Alcalá de Henares: Juan Brocar, 1558), 316v. Fol.

Yutio

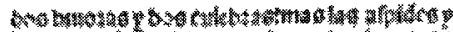

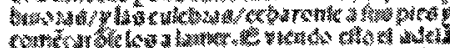
1.*.

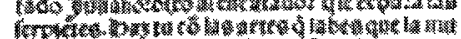
Hrar.

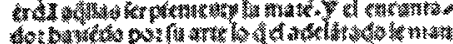

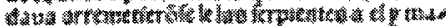

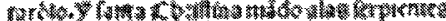
7 10 2.

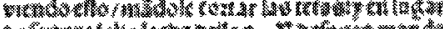

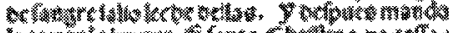



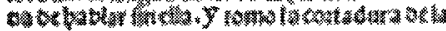

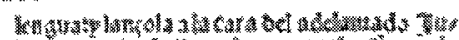

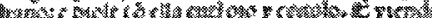

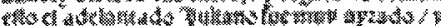
6. 然 14.

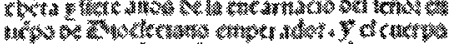
53.

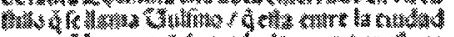

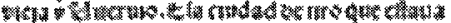
Acote of roc Y)

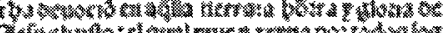

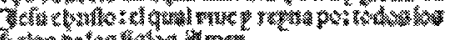

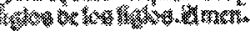

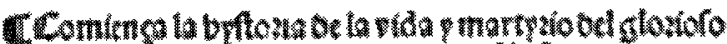

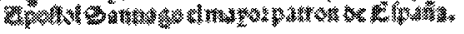

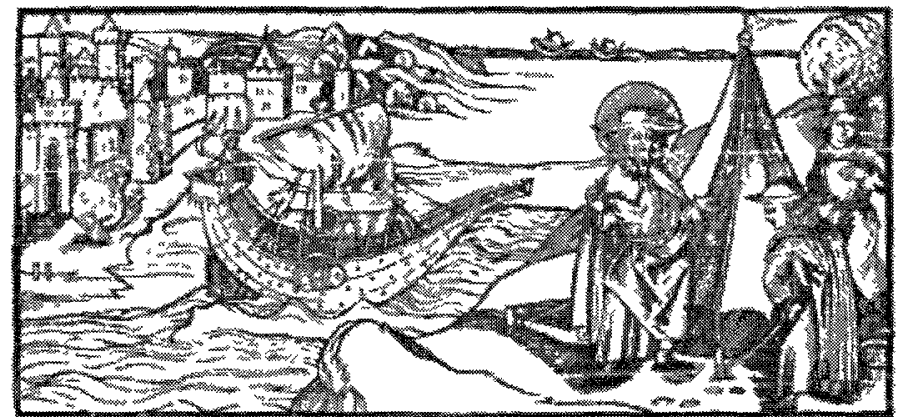

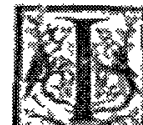

(3)

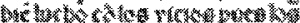

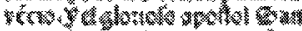

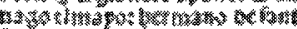

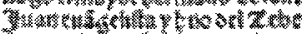

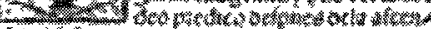

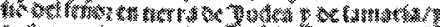




Fer w

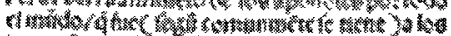
W

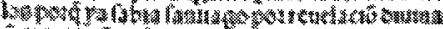
8

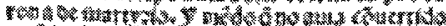
r. 14. 6.

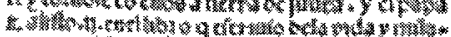

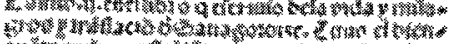

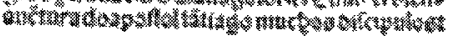

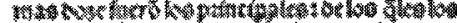

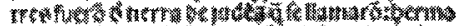

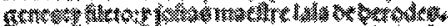

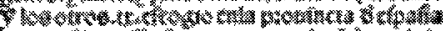

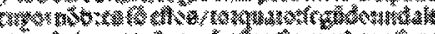

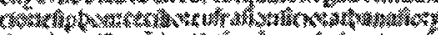

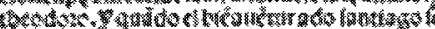



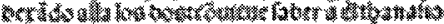

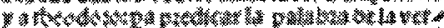
3.

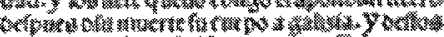

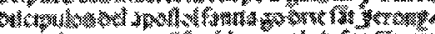

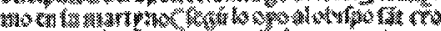

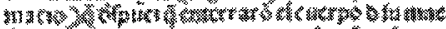
fro or tor 3. (1) 1.

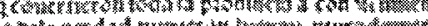
or 
Alonso de Villegas y Selvago Flos sanctorum y historia general, de la vida y hechos de Jesu Christo, Dios y señor nuestro, y de todos los santos (Madrid Pedro Madrigal, 1588), 238r Fol

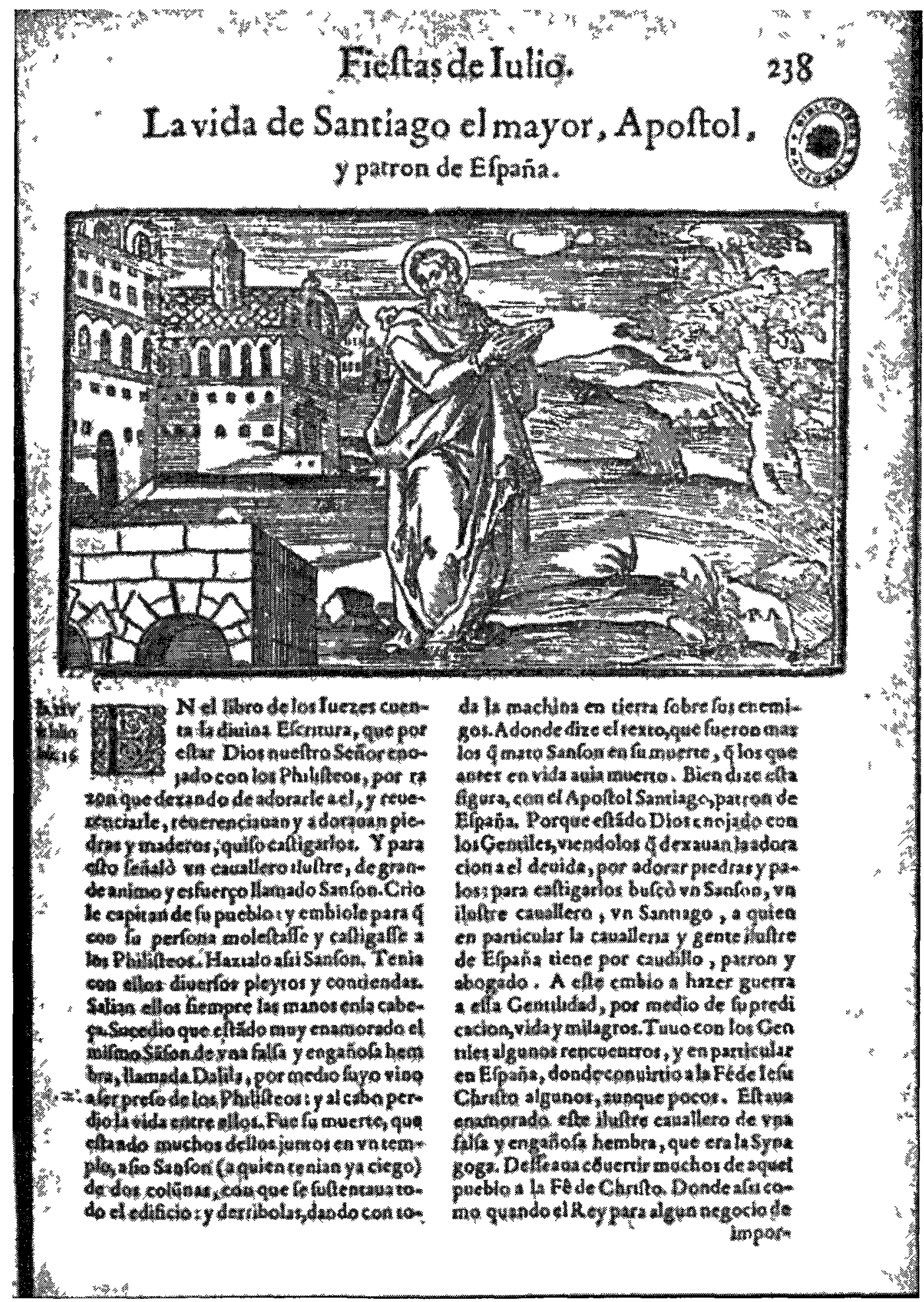


Pedro de Ribadeneyra, Segunda parte del Flos sanctorum, o Libro de las vidas de los santos (Madrid: Luıs Sánchez, 1601), 66. Fol.

\section{Flos Sanctorum.}

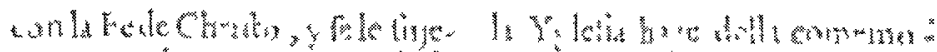

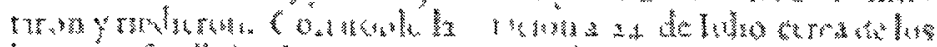
Ir y



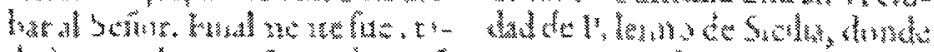



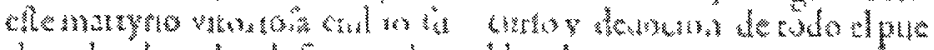

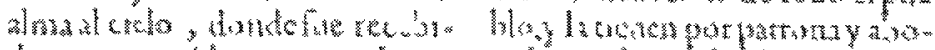

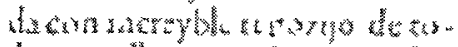
dos aquellor cortefins, yefir.

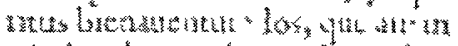

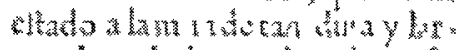



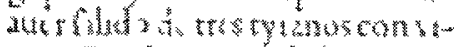

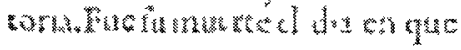



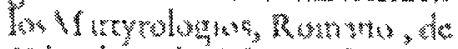

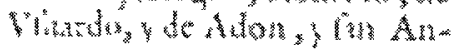

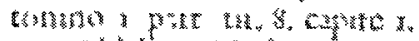

y Alidno Obro, you

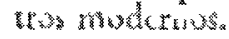
$(x)$

\section{LA VIDA DESAN. tiago el Mayor, Apoltol.}



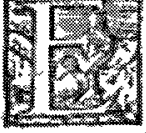

1. Cloruto Apoltal

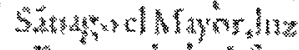

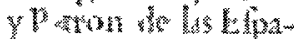



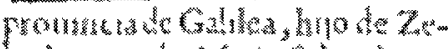
bedco.y de Mans Samb hemaro wayou de Can luan r.

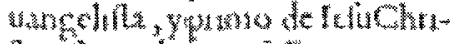

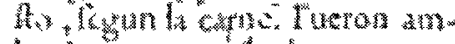


Whate Co plath d zabedeo, que

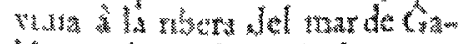
unea : y deua for pelcalor rico, Fics tenu nawio promo, crat

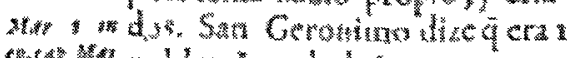

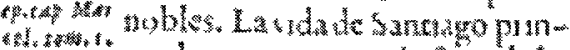

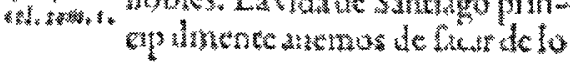

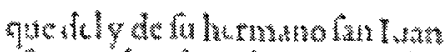

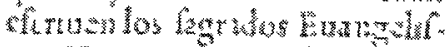

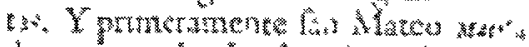

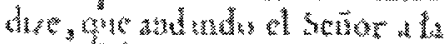

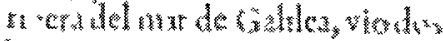
bermaxos, lingh y lisan, gue

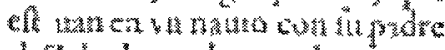

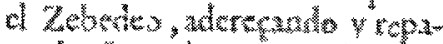

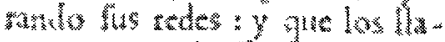

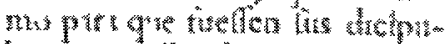
lox yque ells fieran and olde-

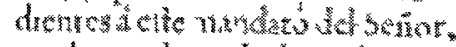



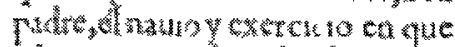

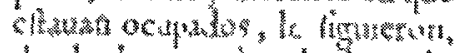

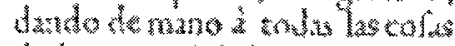
de la treras Aude Can Marcos, sary are 
Pedro de Ribadeneyra, Flos sanctorum; o, Libro de las vidas de los Santos (Madrid: Luis Sánchez, 1604), 573 Fol

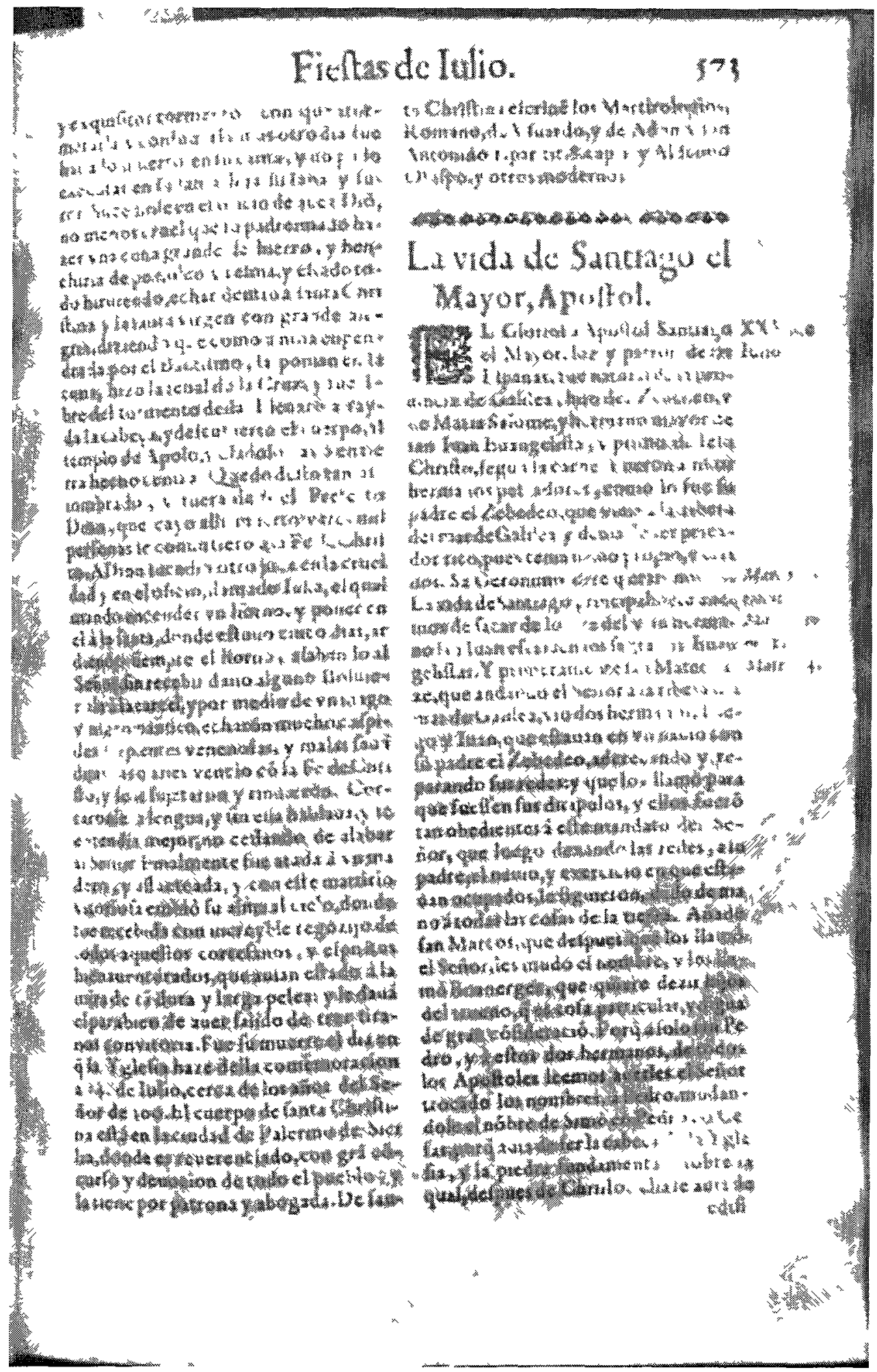


The form and function of Flos sanctorum provided insight into their intended audience. $^{129}$ In comparing the texts produced in Alcalá and Madrid between the midsixteenth century and early into the reign of Philip III, several transformations are apparent (Figure 5 starting on page 48 outlines the changes to the Flos sanctorum). Folio was the standard size of every Flos sanctorum printed during this era with each page arranged in two columns. Vega and Villegas's text used foliation (numbering each leaf), whereas Ribadeneyra employed pagination (numbering each page). There was a noticeable transition from Blackletter to Roman type in these texts. Vega's redactions of sacred biographies were in rotundas, evident in the 1558 and 1572 Alcalá editions. This type fell out of fashion in the mid-sixteenth century but persisted in Spain into the final decades of that century. ${ }^{130}$ Preliminaries in Vega's Flos sanctorum on the other hand were in Roman and italic types. ${ }^{131}$ Editions of Villegas and Ribadeneyra, meanwhile, used Roman and italic exclusively. ${ }^{132}$

Folio-sized volumes lacked the portability of a book printed in octavo. Due to their size, readers had to have sufficient space to adequately open and read these books, whether at the pulpit, in personal or institutional libraries, or seated at a sufficiently sized chair. ${ }^{133}$ An example of the latter site of reading features in El Greco's portrait of Fray Hortensio Félix Paravicino (1609). The painting had the Trinitarian brother sitting and

129 The idea of analysing form and function of texts derives from Paul Grendler, "Form and Function in Italian Renaissance Popular Books," Renaissance Quarterly 46, no. 3 (Autumn 1993): 451-85.

${ }^{130}$ Philip Gaskell, A New Introduction to Bibliography (Oxford: Clarendon Press, 1972 [1985]), 18.

fol. 3 .

${ }^{131}$ Vega, Flos sanctorum (1558), sig. * fol. 2-3; idem, Flos sanctorum (1572), sig. A fol. 2, sig. *

${ }^{132}$ An excellent discussion on the relationship between popular books and typology is Grendler, 459-61, 483-84. For types, see also: Gaskell, 16-25.

${ }^{133}$ Armando Petrucci, "Alli origini del libro moderno. Libri da banco, libri di bissacia, libretti da mano," Italia medioevale e umanistica 12 (1969): 295-313, 303-12. Petrucci discusses the change in book sizes, especially in the fifteenth century. While books had been larger and stationary, after the advent of print they became increasingly portable and corresponded with bodily porportion. A parellel change was from blackletter to Italian type, both developments attributed to the Venetian printer Aldo Manuzio. 
holding a closed folio volume while simultaneously grasping a smaller book. Paravicino used his finger as a page-marker for the reduced-format book, which provided a comparison of the difference in size of early modern reading material. ${ }^{134}$

The works also became less image-intensive, perhaps suggestive of the confidence printers had that the book would sell without any pictorial additions. ${ }^{135}$ Vega's editions had an elaborate title page and individualised representations that corresponded with pivotal saints' lives. The illustrations in Villegas's edition were mostly stock. For instance, the lives of James the Greater, Bartholomew, Andrew, and Thomas used the same image. ${ }^{136}$ Similarly, the lives of Peter and Paul shared a woodcut. ${ }^{137}$ Meanwhile, printers of Villegas's Flos sanctorum used an archetypical picture for Popes and bishops, such as the lives of Bonaventure and Augustine. ${ }^{138}$ Only John, Stephen, Thomas Aquinas, and Sebastian had distinct depictions. ${ }^{139}$ Villegas's own portrait also appeared earlier in the tome. ${ }^{140}$ Ribadeneyra's Flos lacked any pictorial depictions of saints. Only the title page of the 1609 edition had a depiction of the four Evangelists. ${ }^{141}$ While the Society's devotion relied heavily on visuality, some in the order felt that images were an intermediary between visibile and intangible things, and that needless use of images hindered meditation more than they helped. ${ }^{142}$ Villegas's redaction featured images but used Roman type, indicative of crafting a work that could be read aloud or

${ }^{134}$ El Greco, Fray Hortensio Félix Paravicino, 1609, Boston Museum of Fine Arts, El Greco of Toledo, by Jonathan Brown et al. (Boston: Little, Brown and Company, 1982), 2.

${ }_{135}$ Grendler, 458-59.

${ }^{136}$ Villegas, Flos (1588), 238r (James), 293r (Bartholomew), 392r (Andrew), 412v (Thomas).

${ }^{137}$ Ibid. 210 r (Peter), 214r (Paul).

${ }^{138}$ Ibid. 224r (Bonaventure), 298v (Augustine).

${ }^{139}$ Ibid. 92v (Sebastian), 126r (Thomas Aquinas), 417r (Stephen), 419r (John).

${ }^{140}$ Ibid. $19 \mathrm{v}$.

${ }^{141}$ Ribadeneyra, Flos (1609), title-page.

142 Directoria Exercitiontum Spiritualium (1540-1599), ed. Ignacio Iparraguirre (Rome: Monumenta Historica Societatis Iesu, 1955), 196, 301, 395. MHSI 76. See also: Nelles, "Seeing and Writing," 323. 
silently for edification. The inclusion of images corresponded with a popular, lay readershıp of saints' lives. Editions of Ribadeneyra's compilation were imageless and had Roman type aimed at a more professional audience, such as the clergy who would read the Flos aloud during preaching

The early editions of Ribadeneyra's Flos sanctorum featured a plethora of imitable saints who had lived from the first to the sixteenth centuries ${ }^{143}$ Sánchez printed the first and second parts of the Flos sanctorum in 1599 and 1601. Each part contained lives for half of the liturgical year. The 1604 edition combined these two halves in a single volume Sánchez also printed a companion volume, which featured saints named extravagantes. These lives circulated unofficially due to the saints' cults, which operated independently from Rome. The Bollandists' use of the word supports my assumptions on how Ribadeneyra employed 1t. ${ }^{144}$ Other Castilian texts corroborated Ribadeneyra's use of the word extravagantes. ${ }^{145}$ That said, Ribadeneyra's use of the term suggested the continued importance of the lives of extravagantes for Catholics, but also describes these accounts as removed from institutional devotion. By 1604, Sánchez possibly at Ribadeneyra's behest divided the Flos sanctorum into two distinct volumes, one for the canonical saints found withın the Breviary, the other for the extravagantes.

\footnotetext{
${ }^{143}$ For the entirety of saints that feature within every Flos sanctorum, please consult, Appendix 5 . Saints of Varlous Flos Sanctorum

${ }^{144}$ Acta sanctorum Junil (Antwerp Peter Jacobs, 1707), 4892 The Bollandists commented on Ribadeneyra's lıfe of Aloysıus Gonzanga "Ante Sacchınum tamen, praeter alıs, qui Vitam Ceparıanam varıas in linguas transtulerunt indidem extraxit compendium pauculıs adjectıs, lingua Hispana, Petrus Ribadineira, typisque Matrietensibus vulgavit anno MDCIX, post Vitas Sanctorum, quos appelat Extravagantes, qui extra ordınem Breviarı Romani tunc erant, quaemadmodum Extravagantes vulgo audiunt multae Constıtutiones Pontıficae, quia extra corpus Jurıs Canonicı vagantur"

${ }^{145}$ Aesop, La vida y las fabulas del Esopo (Antwerp. Plantin house, 1607), 188, Francisco Diago, Historta de la vida exemplar libros, y mverte, del insigne y celebre maestro $F$ Luys de Granada (Barcelona Sebastian de Cormellas, 1605), 51v For example, Aesop's fables were "Las fabulas extravagantes comiençan en esta orden" In one of Villegas's letters cited in a life of Luis de Granada, Villegas relates how he read extravagantes "yo tambien gasto buena parte del tiempo en leer en las vidas extrauagantes de los santos no canonızados, que es para mi lectura de grande edificacion y consolacion"
} 
Temporally, the majority of the saints included in Ribadeneyra's Flos lived during the first, third, and fourth centuries. Each century between the fourth and the eleventh centuries had between one and five saints. With the exception of the thirteenth century, each century subsequent to the eleventh possessed a single saint. Specific periods in church history had an increased number of saints in the Flos. The early centuries of Christianity's spread and the ongoing persecutions of Christians provided models for preachers and evangelists as well as martyrs. Meanwhile the institutionalisation of Christianity and the advent of Western monasticism witnessed the appearance of a different variety of holy men and women, namely persons who determined doctrine, governed the church, and withdrew from the world to contemplate divinity. These paths to sainthood supplemented the types modelled on early Christians. Moving forward in time, the thirteenth century was the era of the Crusades and the foundation of new religious orders, such as the Dominicans, the Franciscans, the Augustinians, and the Carmelites. The thirteenth century figures augmented the numbers of the church militant and the church triumphant. ${ }^{146}$ By the early seventeenth-century, Urban VIII's legislation of canonisation required recorded examples of theological orthodoxy, heroic virtue, and miracles after death (evidence of intercession). Apparent in the process of recognising saints was an increased emphasis on the observation of their exemplarity, especially

${ }^{146}$ Catechism, 94. "The Church triumphant is that most glorious and happy assemblage of blessed spirits and of those souls who have trumphed over the world, the flesh, and the devil, and are now exempt from the troubles of this life, are blessed with the fruition of eternal life. The Church militant is the society of all fathful still dwelling on earth, and is called militant, because it wages eternal war with those implacable enemies, the world, the flesh, and the devil. We are not, however, hence to infer that there are two Churches: they are two constituent parts of one Church." On the development of the mendicant orders and its desire to recreate apostolic life, see: $\mathrm{CH}$ Lawrence, Medieval Monasticlsm, $3^{\text {rd }}$ ed. (Harlow: Pearson, 2001), 238-78 
evident in early modern trals for canonisation that cross-examined witnesses. ${ }^{147}$ The varieties of saintly experience were diverse as seen in Ribadeneyra's Flos sanctorum.

With respect to type, the saints most heavily represented in the Flos sanctorum are the martyrs followed by members of the church hierarchy (popes, archbishops, and bishops). The vast majority of martyrs in Ribadeneyra's compilation had lived during the second and third centuries, the time of Diocletian's persecution of Christians. ${ }^{148}$ Many of the martyrs venerated as saints were amongst Christianity's earliest converts. Martyrs from other centuries were also included such as Hermenegild (sixth-century), Anastasius the Persian (seventh-century), and Peter of Verona (thirteenth-century). ${ }^{149}$ Thus, in Ribadeneyra's collection of saints' lives, the martyrs flanked the apostles, the nonapostolic evangelists, and other notable New Testament figures. Interestingly, few martyrs experienced canonisation after the resumption of canonization proceedings in $1588 .^{150}$

A noticeable number of the bishops and archbishops contained in the Flos were also martyrs. ${ }^{151}$ Their origins were geographically diverse; these martyred bishops were from England, France, the Levant, Italy, Poland, and Northern Africa. In addition, the early bishops of Rome featured extensively in the Flos sanctorum, most of whom were

147 Donald Weinstein and Rudolph M Bell, Saints and Soctety Two Worlds of Christendom, 1000-1700 (Chicago and New York: University of Chicago Press, 1982), 141-64. $135-47$.

${ }_{148}$ The martyrs of the nascent Church continued to be important in devotion Ditchfield, Liturgy,

${ }^{149}$ Butler, $1145,4 \cdot 39-40$, Gu1lermo Fatás, "La sant1dad y sus antecedentes Santos antıguos y santos anómalos," Revista de Histona Jerónimo Zurtta 85 (2010). 31-33 Hermenegll was a member of the Visigothic royal family in Spain, whose martyrdom initiated the change from Arianism to the Nicene Creed amongst the Visigoths Philip II asked Sixtus V to have Hermenegild canonised

150 Peter Burke, "How to be a Counter-Reformation Saint," in Religion and Society in Early Modern Europe 1500-1800, ed Kaspar von Greyerz, 45-55 (London George Allen \& Unw1n, 1984) I use the reprint found in The Counter-Reformation The Essential Readings, ed David M. Luebke (Malden, MA Blackwell, 1999), 131-39 Example of officially recognised early modern martyrs include Jan Nepomuk (murdered for refusing to divulge the secrets of a confession) and Fidelis of Sigmaringen

${ }^{131}$ of the twenty-five bishops and archbishops, ten were martyrs 
also martyrs. Thus with a handful of exceptions, every Pope from Peter to Damasus I (reigned 366-84) appeared withın the Flos ${ }^{152}$ After Damasus, the contınuity of the papacy developed in the Flos disintegrated and included only six popes after Damasus and none after the seventh century. ${ }^{153}$ Ignatius based the Society's spirituality and missionary work partially on the accounts of the church militant as well as figures from the New Testament.

The Flos houses the majority of the doctors of the Church considered saints for their noted contributions to theology. The Latin doctors (Gregory the Great, Augustine, Ambrose, and Jerome) had featured in the liturgical calendar as a double rite, the same as apostles and evangelists. Their Greek counterparts (John Chrysostom, Athanasius, Basil, and Gregory Nazianzus) did not appear in Roman rites unt1l Pius V included them in the revised Breviary. At the same time, Pius included Thomas Aquinas amongst these doctors and called them 'Doctors of the Church'. ${ }^{154}$ This practice continued with the inclusion of Bonaventure by Sixtus V. ${ }^{155}$ With that in mind, the importance of having the doctors in these redactions cannot be understated due to correlation between confession-

${ }^{152}$ Martyrologium, 499-599 Using the Roman Martyrology, every pope from Peter to Marcellus I (reigned 305/306, exiled 306/307) was a martyr, except for Dionysius (reigned 260 to 267) After that, the martyrology lists the popes from Eusebius to Damasus as the Roman Pope From that time, only Damasus and Sylvester I appears as popes and confessors Ribadeneyra did not have any lives for Sixtus I, Anterus, Dionysius, Eutychian, Eusebius, and Julius I Netther the Roman Martyrology nor Ribadeneyra's Flos sanctorum have any mention of Liberius (reigned 352 to 366) I consulted the Liber pontificalis for information and dates of the popes, I used the following translation Liber pontificalls, trans Raymond Davıs (Liverpool $\cdot$ Liverpool Unıversity Press, 2000), especially 1-31

${ }^{153}$ Liber ponttficalls, 31-95 The later popes represented within the Flos were Innocent I, Confessor (r 401/2-17), Leo I the Great (r. 440-61), John I, Martyr (r 523-6), Gregory I the Great, Doctor (r 590-604), Martın I, Martyr ( $\mathrm{r}$ 649-53/5), Leo II ( $\mathrm{r}$ 682-3) On the early modern pontıffs as saints, see Ditchfield, Liturgy, 212-69.

${ }^{154}$ Jean-P1erre Torrell, Saint Thomas Aquinas His Life and his Works, trans Robert Royal, rev ed, 2 vols (Washington, D C Catholic University of America Press, 2005), 1325 Boniface VIII had started this liturgical practice in 1295 with the Latın doctors.

${ }^{155}$ Competition between religious orders manifests when comparing the bestowal of the title 'doctor' onto Thomas Aquinas and Bonaventure Pius V was a Dominican, who included another Dominican, Thomas, into the milieu of the Church's superlatıve theologians Sixtus V, meanwhile, as a Franciscan worked towards the minor friar Bonaventure's placement amongst the other doctors A religious order's identity sought official recognition, while maintaining distınction 
building and explicit statements of doctrine. Apart from the elevation of Thomas Aquinas and Bonaventure to Doctors, no theologian underwent canonisation between 1588 when the practice resumed and $1757 .{ }^{156}$ According to Ignatius, both positive and scholastic theologians in conjunction with ecclesiastic counclls, canons, and constitutions revealed the purported divine truth of the Catholic church. ${ }^{157}$

Monks were also included in the Flos sanctorum. Two varieties of accounts on monks featured in the Flos sanctorum that resembled a history of western monasticism: eremitic and cenobitic lives. Hermits as practitioners of eremitic monasticism retreated to the real or the symbolic desert to depart from the world and to spend time in meditation and prayer. Cenobites were ascetics gathered in communities following a rule and led by abbots. ${ }^{158}$ The lives of hermits comprise those of Antony the Anchorite, Paul of Thebes, Hilarion, and Giles. ${ }^{159}$ Meanwhile, John Cassian and Sabbas were included as figures who formed religious communities and monasteries, which maintained the asceticism of the hermits. The lives of cenobites included the biography of Benedict of Nursia the composer of the Rule of St Benedict followed by that of Maurus, Benedict's first disciple. The narrative continued into the High Middle Ages with Romuald and Bernard of Clairvaux, who shared similarities to Cassian and Sabbas. Akin to Sabbas, Romuald as

${ }^{156}$ Burke, "Counter-Reformation Saint," 136-39.

${ }^{157}$ Ignatıus, Exercitıa Spintualıa, [363]. "Alabar la doctrına positıua y escholástıca, porque assí como es más proprio de los doctorspositıuos, assí como de Sant Hierónımo, SantAugustín y de Sant Gregorio el mouer los afectos para en todo amar y seruir a Dios nuestro Señor, assí en más propio de los escholástıcos, así como de sanctoThomás, san Bonventura Porque los doctorsescholástıcos, como sean más modernos, no solamente se aprouechan de la vera intellıgencia de la Sagrada Scriptura de los positıuos y sanctosdoctors, mas aun siendo ellos illuminados y esclarescidos de la virtud diuina, se ayudan de los conçılıos, cánones y constıtuçıones de nuestra sancta madre Yglesıa"

${ }^{158}$ On the beginnings of western monasticism, see Lawrence, 1-36 Ditchfield examines the aristocratic hermit as a saintly monk in Ditchfield, Liturgy, 148-80

${ }^{159}$ Butler, 1 101-2, 116-19; 9. 5-7, 10.146-47 While Paul of Thebes was Christianity's first hermit, Anthony is considered the father of Western Monasticism According to the traditional accounts, Antony buried Paul after his death with a garment given to Antony as a gift from Athanasius Hilarion, meanwhile, lived according to the example of Antony. Giles did not necessarily follow the example of the Desert Fathers, he was an early example of a hermit in Western Europe 
the founder of the Camaldolese Order was the founder of distinct monastic communities. Meanwhile, Bernard similar to Cassian was an abbot and theologian as well as promoter of his order the Cistercians. What separates Cassian and Sabbas from Romuald and Bernard was therr adherence to the Rule. While the Jesuits were not monks, these accounts pertaining to monasticism were important due to therr depiction of communities of religious men living together under a rule. While Jesuits did not live under a rule, the concept of community resonated amongst the early Jesuits. ${ }^{160}$

The presence of women in the Flos sanctorum revealed the early modern d1lemmas over female sanctity. ${ }^{161}$ While women featured in the accounts of martyrdom, they did not appear as frequently as men. ${ }^{162}$ Many of these female martyrs received the labels of virgins and martyrs to reinforce Ribadeneyra's conceptions of early modern Catholic gender norms that he wished to impart upon others The other female sants in the Flos, however, corresponded to the gendered expectations of the age. For example, Praxedes was a saintly virgin, whereas Monica's sanctity was solely contingent on being both a widow and the mother of another saint. In Monica's case, the Flos always describes her as the mother of Saint Augustine, as if her sanctity was contingent on her

${ }^{160}$ O'Malley, First, 335-45, 369. In comparison, Augustınians were canons regular, clerical communities rooted to a locality that follow a monastic Rule but involved themselves in public ministry. Domınıcans and Franciscans were mendicants, orders of friars dedicated to public minıstry They, however, travelled from place to place. Mendicants supported themselves through begging and refused to own property (though the laxity of these ideals became the fuel for controversies in the Late Medieval and Early Modern periods) With respect to religious organısation, the Society of Jesus were clerks regular. They akın to canons regular and mendicants were active participants in public ministry Similar to the mendicants, they were not necessarily tied to a specific area. While Polanco ransacked the rules of various orders when drawing up the Constitutions, they had a rule, but not a monastic one The aim of the Constitutions and to a certain extent the Regulae were to enable cohesion in the order, not uniformity

${ }^{161}$ On the religious gender norms of the age, see Alhgren, 6-31, Weber, 17-41.

162 The female saints in the Flos sanctorum were martyrs of the early Church, the majority from the third and fourth centuries In comparison, there were thirty-six accounts of male martyrs, while only twenty concerning female martyrs The difference between the martyrs of the first and the second centuries is minimal 
issue. ${ }^{163}$ The descriptors for Clare of Assisi, founder of the Poor Clares, also conform to a comparable standard. In the 1601 and the 1604 editions of the Flos as well as in the Breviary, she is listed as only a virgin. No description of her as a founder of a religious order ever appears. ${ }^{164}$ Ribadeneyra listed male founders of tertiary orders as founders, while he refused to apply the same name to female founders. For instance, Romuald appeared as the founder of the Camoldensians, an offshoot of the Benedictines. ${ }^{165}$ Similarly, Ribadeneyra named John Gualbert as the founder of the Benedictine-derived order the Vallumbrosans. ${ }^{166}$ For Ribadeneyra, women could be members of religious orders, but could not found them.

The other founders of religious orders were male and betrayed the relatively recent creation of orders. Gualbert and Romuald were active in the tenth and the eleventh centuries. Claire, Francis of Assisi, and Dominic were notable religious founders in the thirteenth century. The latest of the founders were Francis of Paola (of the Minims) and Ignatius from the fifteenth and the sixteenth centuries. The saints in the Flos sanctorum associated with an order were religious men and women from the High and Late Middle Ages: they lacked the lineage of monastic communities for example. The Dominicans had two saints (Thomas Aquinas and Peter of Verona), whereas the Franciscans had three (Bonaventure, Anthony of Padua, and Diego de Alcalá). From the Augustinians, founded in the thirteenth century, almost a millennium after Augustine's death in 430, there was a single saint, Nicholas of Tolentino.

\footnotetext{
${ }^{163}$ Ribadeneyra, Flos (1599), sig. ๆศศा 3r; idem, Flos (1604), sig. ๆศा $2 \mathrm{r}$.

${ }^{164}$ Breviarium, 18; Ribadeneyra, Flos (1601), sig. I 5v; idem, Flos (1604), sig. १ๆ 3r.

${ }^{165}$ Ribadeneyra, Flos (1599), sig. ๆTी 2v; idem, Flos (1604), sig. 9ा 1 $\mathrm{v}$.

${ }^{166}$ Ribadeneyra, Flos (1604), sig. १ๆ $3 \mathrm{r}$.
} 
In comparing the five editions of the Flos sanctorum printed during Ribadeneyra's lifetime (1599, 1601, the two 1604 works, and 1609), the more prominent saints' lives in these collections conform to the Roman Breviary of 1568, the Gregorian reforms to the calendar introduced in 1582, and the Roman Martyrology of 1584. Similar practices were evident in Villegas's Flos sanctorum. While the calendar of feast days in Ribadeneyra's 1599 edition contained errors, subsequent editions correctly conformed to the new Gregorian calendar. ${ }^{167}$ Saints that featured in the Martyrology but not in the Roman Breviary formed another tier of sanctity, the extravagantes. While extravagantes continued to be important in Catholic devotion, they were not a part of the official Catholic liturgy and lacked the pre-eminence of the saints within the Roman Breviary. Ribadeneyra and Villegas constructed a new hagiographical tradition based on postTridentine reforms while maintaining the Lippomano-Surius tradition. While Ribadeneyra considered Lippomano and Surius important hagiographical predecessors, he also included them amongst medieval martyrologies, the Roman Martyrology, and Caesar Baronius's Annales ecclesiastici as well as his annotations to the Roman Martyrology. Ribadeneyra's placement of his Flos sanctorum amongst the Tridentine liturgical works, Surius and Lippomano's hagiography, and ecclesiastic history were part of his efforts to construct a conception of the heirarchical Catholic church in the age of confessionalisation based on observation. ${ }^{168}$

${ }^{167}$ The calendar is found in Christopher Clavius, Opera mathematicorum, 5 vols. (Mainz: Johann Volmar, 1612), 5: 5-8. The erroneous Gregorian calendar featured in Ribadeneyra, Flos (1599), sig. ๆTf fol. 2-4. The remaining calendars are 1 dem, Flos (1601), sig \f fol. 5-7; tdem, Flos (1604), sig. 919 fol. 1-4.

${ }^{168}$ Ribadeneyra, Flos (1599), sig. 19 5v-6r, "Los Autores que he seguido en escriuir estas vidas, son los mas graues, y de mayor autoridad que ay, y conocidos, y recebidos por tales de toda la Yglesıa Catolıca, y los Martyrologios, Romano, de Beda, Vsuardo, y Adon. Tambien me he ayudado de los pradoss trabajos de Luis Lipomano, Obıspo de Verona, y del Padre fiay Lorenço Surıo, monge Cartuxo, varones en vida, doctrina, y zelo de la honra de los Santos, sıgnos de perpetua alabança y recordacion. Y no menos me he aporuechado de los Anales, y de las anotaciones sobre el Martyrologio Romano del ilustrissimo 
The developments in hagiography were apparent through an examination of saints venerated in the Province of Madrid. ${ }^{169}$ Most of the saints' lives in the Flos sanctorum by Vega, Villegas, and Ribadeneyra appeared consistently throughout the sixteenth century. The hagiographers added saints to their redactions, such as Villegas's inclusion of Gregory of Nazianzus and Michael as well as Ribadeneyra's insertion of Diego de Alcalá. These changes corresponded with Gregory's promotion to a Doctor of the Church and Diego's canonisation. ${ }^{170}$ Michael's cult had declined since the era of the Crusades, but he had a feast day unlike the other archangels Gabriel and Raphael. ${ }^{171}$ Quiteria, meanwhile, featured in Vega and Villegas's redactions but disappeared from them subsequently ${ }^{172}$ Another popular saint, Scholastica, never appeared in the compilations. In the 1604 supplement, these extravagantes formed a separate collection alongside the

Cardenal Baronıo al qual escogıo el Señor en estos nuestros tiempos tan calamitosos, para que con vn estudıo infatıgable, è increuble diligencia, empleasse la mayor y mejor parte de su vida, en la leccion de las vidas y libros de los Santos, y con maduro y acertado juyzio resucitasse algunas cosas que estauan sepultadas, obseruasse, y recogiesse otras esparzıdas, auerıguasse las dudosas, diesse luz à las escuras, è 1lustrasse la historia Ecclesiastica, con singular beneficio de la Republica Christiana"

${ }^{169}$ These community questionnaires can be found collected in Relaciones histónco-geográficoestadísticas de los pueblos de España hechas por iniciatıva de Felipe II Provincia de Madrid, eds Carmelo Viñas y Mey and Ramón Paz, 3 vols (Madrid Consejo Superior de Investıgaciones Científicas, 1949), 1 8-738 The list of saints derives from the questionnaires from the Province of Madrid Abdon and Sennen, Agatha, Andrew, Anna, Antony the Anchorite, Anthony of Padua, Athanasius, Augustıne, Barbara, Barnabas, Bartholomew, Benedict of Nurısa, Bernardino of Siena, Blasse, Bonaventure, Brigit, Catherine of Alexandria, Cecıllia, Cosmas and Damıan, Dıego de Alcalá, Domınıc, Eugene of Toledo, Four Crowned Ones, Francis, Gabriel, George, Gregory the Great, Gregory of Nazianzus, Gregory of Nyssa, Hippolytus of Rome, Ildephonsus of Toledo, Isidore of Seville, James the Greater, James the Lesser, John the Apostle, John the Baptıst, Joseph, Jude, Justus and Pastor, Luke, Mark, Martın of Tours, Mary Magdalene, Matthew, Michael, Nicolas, Pantaleon, Paul, Peter, Peter of Verona, Philip, Quiteria, Roche, Scholastica, Sebastian, Simon, Stephen, Sylvester, Thomas Aquinas, Turibius of Astorga, Valentıne, and Vincent of Zaragosa

${ }^{170}$ Butler, 1 16-19, 11 102, Burke, "Counter-Reformation Saint," 132, 138 Twenty-five years after Trent, the practice of canonisation resumed in the promotion of Didacus or Diego de Alcalá, a Franciscan laybrother active as a missionary in the Canary Islands One reason for this canonisation was the petitions made for Diego by Philip II Diego's intervention yielded a miracle favourable to Philip's son Gregory of Nazianzus's most celebrated contribution is his teachıngs on the Trinity akın to Basil the Great

${ }^{171}$ Peter Marshall and Alexandra Walsham, "Migrations of Angels in the Early Modern World," in Angels in the Early Modern World, eds Peter Marshall and Alexandra Walsham (Cambridge and New York Cambridge University Press, 2006), 11-12

${ }_{172}$ Butler, 5116 While her name appears in the Roman Martyrology, the detalls about her life are legendary For this reason, Ribadeneyra and Villegas might have dropped this saint from their roster, although her cult spanned Portugal, Spain, and southern France 
Flos sanctorum "because the holy church does not read about them in the Roman Breviary "173 The majority of the canonical saints and extravagantes were male of the 273 canonical saints' lives, thirty-nine were lives of santly women Meanwhile, Ribadeneyra's collection of extravagantes had fifty-two lives, fifteen focussed on female extravagantes Gregory of Nyssa only appeared in the extravagantes published in $1609^{174}$ The lives of Bernardino of Siena, Brigit, and Roche had featured in the Flos sanctorum of Vega and Villegas, but Ribadeneyra placed them amongst the extravagantes in 1604 and $1609{ }^{175}$ While extravagantes contınued as an acceptible form of saint veneration, they lacked the prestige and relatively universal devotion of saints in the liturgical works, such as the Breviary

Ribadeneyra's construction of a new approach to hagiography also encompassed the biographies of Jesuits Both the 1601 and the 1604 editions included the life of Ignatius of Loyola In 1601, he featured at the conclusion of the lives of those saints found in the Roman Breviary Ribadeneyra changed Ignatius's life in the 1601 Flos to include other miracles not present in both his Latın and Castilian Vita Ignatı Loiolae In the 1604 edition, however, Ignatius resided among the extravagantes Ignatius's canonisation proceedings had begun in 1595, with trials in Spain and Italy By 1602, Pope Clement VIII expressed concern about the veneration of Ignatius and Francis Xavier as saints or beatı as they had not yet even received beatıfication Indeed, they

\footnotetext{
${ }^{173}$ Ribadeneyra, Libro de las vidas de santos, cover page

${ }^{174}$ Butler, 1 64-66 Gregory advocated for a life built on imitation "to be Christian is basically to imitate God as this imitation is proposed to us in Christ, an imitation that is an assimilation to what God actually is" (65) He and Nazianzus were cenobites

${ }^{175}$ Butler, 5 107-8, 7 180-86, 8 162-64, Burke, "Counter-Reformation Saint," 133 Roche's cult existed since the fourteenth century, but lacked official recognition Sixtus V provided Roche with two optıons "elther to canonıse him or to oblıterate hım" By the early seventeenth-century, special masses were authorised for Roche Bernardino was a renowned Franciscan preacher in the fifteenth century, whereas Bridget was a foundress of Brigettınes
} 
respectıvely underwent beatıfication in 1609 and 1619 before the elevation of both to sainthood in $1622^{176}$ By 1609 , the biographies of five Jesuits were scattered amongst the extravagantes. Ignatius, Xavier, Francis Borgia, Aloysıus Gonzaga, and Stanıslaus Kostka These Jesuits also had individually assigned feast days indicatıve in part of their ongoing canonisations and beatificatıons. ${ }^{177}$ Thus, Ribadeneyra incorporated into his Flos sanctorum Jesuit 'saints' amongst early modern Catholic cults of saints. Other examples of a sanctified Society's integration into early modern religious life manifested in the seventeenth century included Catholics naming churches after Xavier, the dispersal of cults for Ignatıus and Xavier in Naples and Bavaria, or the sanctification trials underway for Ignatius, Xavier, Gonzanga, and Kostka ${ }^{178}$ Rubadeneyra's inclusion of recently canonised saints and non-canonical figures, however, was inconsistent for saints outside the order. Amongst the newly minted saints, Diego de Alcalá had featured in every edition since 1599, while Jacek Odrovaz and Raymund de Peñaforte emerged in the 1609 extravagantes. ${ }^{179}$ Of the recent beat, Ribadeneyra included Gonzanga and Kostka alone, while thee others never made an appearance. ${ }^{180}$

${ }^{176}$ Burke, "Counter-Reformation Saint," 133-34, Simon Ditchfield, "Coping with the Beatı Moderni'. Canonization Procedure in the Aftermath of the Council of Trent," in Ite inflammate omnia, ed Thomas M McCoog (Rome Institutum historicum Societatıs Iesu, 2010), 419-25 The process to canonise Francis began soon after his death in 1552, the venues for his trials were in India, Portugal, Spain, and Italy For an example of a falled canonisation, see Simon Ditchfield, "How Not to be a CounterReformation Saint The Attempted Canonization of Pope Gregory X, 1622-45," Papers of the Brittsh School at Rome 60 (1992) 379-422

${ }^{177}$ Burke, "Counter-Reformation Saint," 137, Ditchfield, "Copıng with the 'Beat Moderni'," 416 n 17, Ribadeneyra, Flos sanctorum (1609), sig 1 fol 4-5 For example, June $20^{\text {th }}$ for "B Luıs Gonçanga de la Compañía de Jesus", July $31^{\text {st }}$ for "B Padre Ignacıo de Loyola fundador de la Compañía de Jesus", August $14^{\text {th }}$ for "B Estanislao KosKa, de la Compañía de Jesus", September $30^{\text {th }}$ for "B Francisco de Borja, de la Compañía de Jesus", December $2^{\text {nd }}$ for "B Francisco Xavier Apóstol en la India, de la Compañía de Jesús" Gonzanga and Kostka were beatıfied in 1605 Ignatıus and Xavier underwent canonisation in 1622 along with Teresa of Avila, Isidore the Labourer and Philip Nerı Borgia was beatified in 1624, then canonised in 1670 Kostka and Gonzanga were canonised in 1726

${ }^{178}$ Burke, "Counter-Reformation Saint," 141-42, Ditchfield, "Coping with the 'Beatı Moderni,",

${ }^{179}$ Ditchfield, "Coping with the 'Beatı Modernı'," 418-19 Jacek (Jacinto) was a Polish Domınican canonised in 1594, while Raymund was part of the same order but a Spanish missionary He was canonised 
The Flos sanctorum genre first emerged in the fourteenth century in the Iberian Peninsula and was the progeny of the Legenda aurea. It was a compilation of saints' lives assembled by the Dominican friar Jacobus de Voragine in the thirteenth century. Medieval manuscripts of the Flos sanctorum were abridgements of the expansive Legenda aurea. They appeared in the Legenda's original Latin as well as Castilian, Catalan, and Portuguese translations. ${ }^{181}$ Such abridgements were common in late medieval culture and they attempted to organise and to make readily available whatever was considered worth knowing, a practice evident in margarita philosophiae, or 'the pearl of philosophy' ${ }^{182}$ By the fifteenth and early sixteenth centuries, these texts appeared infrequently in Latin, but had repeated printings in the vernacular. ${ }^{183}$ Attitudes towards Voragine's collection changed prior to the sixteenth century, most evidently in the transformation of the word 'legenda'. It had previously referred to anything read, but had become a pejorative term for anything unbelievable or unfit for belief. As a result, compilations of saints' lives from Voragine's tradition adopted other names, such as

in 1601. I looked for the other figure canonised prior to 1609 Francesca RomanaPonziani amongst the extravagantes but did not find her there. This practice was suggestive of Ribadeneyra's omission of female canonical saints and the extravagantes.

${ }^{180}$ The beati in question were (with date of beatification): John of Sahagún (1601), Colette Boylet (1604), Salvatore Horta (1606), Louis Bertran (1608), Margaret of Citta di Castello (1609). Of note, John and Colette received beatification prior to Kostka and Gonzanga. The Catholic church beatified Ignatius alongside Margaret as well as after Salvatore and Louis. Ribadeneyra selected the saints that featured in the Flos sanctorum intentionally.

${ }^{181}$ DHEE s.v. J. Vives "Flos sanctorum"; Baños Vallejo, Vidas de santos, 228-31; Billy Bussell Thompson, "'Plumbei cordis, oris ferrei:' la recepción de la teología de Jacobus a Voragine y su Legenda aurea en la Península," in Saints and their Authors, eds. Jane E. Connolly, Alan Deyermond, and Brian Dutton (Madison: Hispanic Seminary of Medieval Studies, 1990), 97-106; Reames, 11-15, 27-43.

${ }^{182}$ Christel Meier, "Organisation of Knowledge and Encyclopedia Ordo: Functions and Purposes of a Universal Literary Genre," in Pre-Modern Encyclopedic Texts, ed. Peter Binkley (Leiden: Brill, 1997), $109-11$.

${ }^{183}$ Baños Vallejo, Vidas de santos, 240-54. 
Trésor des prédicateurs (Treasure of Preachers), Lignum vitae (Tree of Life), and of course, Flos sanctorum ${ }^{184}$

Criticisms of Voragine and his Legenda aurea exploded in the sixteenth century, especially amongst humanists and Protestant reformers who focussed on the perceived fictions and exaggerations to the Legenda aurea. ${ }^{185}$ For example, humanist Juan Luis V1ves attacked Voragine's debasement of saintly narratives: "what an insult is this history of saints to blessed and Christian men, which is named the Golden Legend. What I do not know is why it is called golden, since it was written by a man with a mouth of iron, [and] a heart of lead." 186 Another example was Erasmus's satire of the genre from his colloquy The Young Man and the Harlot (1523), which retold the story of St Thaïs, a prostitute who repented and atoned for her sins. With acerbic wit, Erasmus's intent was to promote the preservation of chastity, albeit without the triteness of other hagiographical accounts ${ }^{187}$ For both, compilations of saints' lives such as the Legenda aurea had become problematic collections worthy of only derision or mockery.

Protestant reformers also had reservations about hag1ography, though some acknowledged its utılity for Chrıstian devotion. For Luther, these sentiments appeared in his preface to Georg Major's Lives of the Fathers (1544), a compilation of Lutheran-

\footnotetext{
${ }^{184}$ Reames, 61, Vega, Flos (1558), 1r; Vega, Flos (1572), 1r The title pages of Vega's editions included an image of the tree of life and in small letters lignum vitae

${ }^{185}$ Euan Cameron, Enchanted Europe Supersttton, Reason, and Religion, 1250-1750 (Oxford and New York Oxford University Press, 2010), 146-73, 196-210

${ }_{186}$ Juan Luis Vives, De disciplinis libris XII, septem de Corruptis Artibus, quinque de tradendts Disciplinis (Naples Typographra Simonia, 1764), 96 "Quam indigna est divis atque hominibis Christranis 1lla sanctorum historia, quae Legenda aurea nominatur, quam nescio cur auream appellent, quum scripta sit ab homine ferrel orls, plumbel cordis " The first printing of De disciplinis was 1531

${ }^{187}$ Desiderius Erasmus, "The Young Man and the Harlot," in Collected Works of Erasmus, vol 39, Colloques, trans Craig R Thompson (Toronto, Buffalo, and London University of Toronto Press, 1997), 382-86
} 
sanctioned saints' lives ${ }^{188}$ In his preface, Luther criticised the Legenda aurea, also known as the Legenda sanctorum, for its fables and its lies The preface's first sentence summarised his disdain

This text is not the worst of those other works of satanic fury, which they call histories, or indeed, the Legenda sanctorum. Many of which prove incorrect and which it allowed to be put aside (intending to be unquestionable in every way), and thus it destroyed stupid imaginings and impious lies so that certain true stories might be seen to be more coherant and useful. ${ }^{189}$

While Lutherans retained saints and the accompanying literature about their lives, they partıcularısed saints according to their confession. Lutherans did not pray to saints, but rather recalled them as exemplars of pious living In accordance with the Lutheran doctrine of sola scriptura, only figures from the Bible could have the title of 'saint' appear with their name such as Saints Peter or Paul. Persons absent from the Bible were still saintly and appropriate for the doctrine of the priesthood of all believers, but they lacked the official title of 'saint'. For instance, Lutheran texts referred to Thomas Aquinas or to Antony the Great in de-canonısed form. ${ }^{190}$ Lutheran hagiographies depıcted the confession-specific life of piety for Lutherans with exemplars. ${ }^{191}$ Good examples for Lutherans to follow in Major's Vttae patrum included the lives of Egyptian monks, such as Antony and Paul the Hermit. ${ }^{192}$

${ }^{188} \mathrm{Kolb}, 33-40$

${ }^{189}$ Martin Luther, "D Martinus Luther, pio lector1 salutem," in Georg Major, Vitae patrum in usum ministrorum verbi quo ad elus fien potuit reprugare (Wittenberg [Seltz], 1544), s1g A 1v "[I]nter cetera Satanicı furoris opera hoc non minımum est, quod historias, seu quas vocant, Legendas sanctorum, $\mathrm{q}[\mathrm{ue}]$ plurimas aboleverit, et quas extare passus est (haud dubre non volens), ita corruperit fabulis stultis et impiss mendaciss, ut veri multo sint similiores et utıliores gentıum quaedam fabulae"

${ }^{190}$ Kolb, 11-40, 139-58, Scribner, "Incombustible Luther," 39-46, 62-68, W1ess, 174-95

${ }^{191}$ Backus, Life Writing, 2-20, Kolb, 103-38 Compare with Melanchthon's Life of Luther Philip Melanchthon, "History of the Life and Acts of Dr Martin Luther," in Luther's Lives, eds Elizabeth Vandiver, Ralph Keen, and Thomas D Frazel (Manchester and New York Manchester Unıversity Press, 2001), 14-39

${ }^{192}$ Major, Vitae patrum, 64r-73r (Paul the Hermit), 108r-171r (Antony) Major contınued to refer to Antony as a saint 
Calvinists also criticised hagiography yet also retained saints and hagiography. The Calvinist definition of sainthood, like Luther's, derived from the New Testament. ${ }^{193}$ Calvinist saints were those set apart by God, persons saved through predestined salvation. According to Calvin, the elect and the sainted would never fall away from God. Lutherans believed that while people drift apart from God, the fallen were not removed from the godly community, rather God provided assurance for salvation. For Calvinists, God predestined salvation or damnation; once decided by the grace of God, the person could not alter or change their fate Calvinist saints remained exemplary figures worthy of emulation since this outward sanctity suggests, but does not prove, predestined salvation Calvinists continued to write hagiographies although the characteristics of saint changed. Calvinist 'saints' were that confession's founder and theologians. ${ }^{194}$ While Calvinist biographies focused on reformers, they also shared the Lutheran tendency to communicate exemplary lives. Catholics, Lutherans, and Calvinists thus retained a hagiographical culture, built upon modified definitions of sainthood.

Reformed criticisms of hagiography appear most notably in John Foxe's Acts and Monuments. In a brief prologue addressed to the reader, Foxe singled out the Legenda

${ }^{193}$ Saints are simply believers in Christ committed to living a devout life Implied in the use of this word is a separation between this 'Christian' community and all others For example, "Now as Peter went here and there among all the believers, he came down also to the saints living in Lydda" Acts 932 or "with authority received from the chief priests [the Sanhedrın], I [Agrıppa II, kıng of Judaea] not only locked up many of the saints in prison, but I also cast my vote against them when they were being condemned to death" Acts 26 10. Paul outlines who are saints, "The gifts [Chrıst] gave were that some [believers] would be apostles, some prophets, some evangelists, some pastors and teachers, to equip the saints for the work of ministry, for bulding up the Body of Christ, untıl all of us come to the unity of fatth and of the knowledge of the Son of God, to maturity, to the measure of the full stature of Christ" Ephesıans 4 11-13 All Biblical quotations come from The Oxford Annotated Bible (New Revised Standard Version)

${ }^{194}$ Backus, Life Writing, 126-38. 
aurea for criticism. ${ }^{195}$ Foxe fixated on the distortions to the narratives apparent in the Legenda aurea, likening the hagiographies to Homeric epic fictions.

Why do you not disappear with your Golden Legends, shameless trifler! I know that this book, as we all know it and even you yourself are not unaware, spreads the wondrous portents of falsehoods and the falsest imaginings such that I am even not willing to compare it to the tales of Homer. It is so lacking that, in truth, it has nothing in common with the holy and serious histories of the church. ${ }^{196}$

Foxe indicted the reader of the Legenda aurea as a participant in the Catholic church's debasement of the Christian fatth:

These and certain other miracles written about the saints and religious men are the proof, which are nearly all added to this Legendary and yet are known by us to have in no way been from that place, to such an extent that they are outlined in the Legendary of the Pope as highly suspect to the faithful ${ }^{197}$

Obviously, sacred biography by the early and mid-sixteenth-century inspired mockery and not devotion

Books about saints, however, played a role in everyday life for both the literate and non-literate. The late medieval production of hagiographical literature continued and flourished after the advent of printing. ${ }^{198}$ Preachers used saints' lives to provide examples of appropriate Christian virtue in their sermons. ${ }^{199}$ People heard the occasionally fantastic

${ }^{195}$ John Foxe, Actes and monuments of these latter and perlous days, (1563 edition), [online], (hriOnlıne, Sheffield), avallable from ' http //www hrionline shef ac uk/foxe/, [Accessed 2806 2011], 9-11 Only the 1563 edition has this Latın preface (I cannot find it translated anywhere)

${ }^{196}$ Foxe, 10 "Quinapage cum Aurea tua legenda, nugator impudens, quem ego librum, cum omnes eum scimus, nec ipse ignoras prodigiolıs mendaciorum portentıs \& vanıssimis vndique commentıs scatere, ne cum Homerı quidem fabulis conferre velım tantum abest ut cum vere ferıs graubusque ecclesiae historis quicquam commune habeat"

${ }^{197}$ Ibıd "Sunt praetor haec \& alıa quaedam de Sanctıs \& Diuıs conscripta miracula, quae propıus ad Legendam hanc accedunt, \& tamen nequaque eo loco apud nos habentur, ut Legendae ill Papisticae annumerentur, etram quae suspectissimae sunt fides"

${ }^{198}$ Manuel Peña Dıaz, "Relıgıosıdad y lıbros 'populares' en el sıglo XVI," in Polittca, relıgıón e ınquisıción en la España moderna, ed Pablo Fernández Albaladejo et al (Madrid Unıversidad Autonoma de Madrid, 1996), 529-47 especially 535-39 Peña Díaz discusses other popular relıgıous works in early modern Spain, such as books of hours as well as lives of Christ and Mary

${ }_{199}$ Lucien Febvre and Henr1-Jean Martin, The Coming of the Book, trans David Gerard, new ed (London Verso, 1997), 47-48 
tales of these saints read to them on feast days. Between 1575 and 1580, New Castilians advocated for numerous saints to protect them from various ailments and sufferings. The saints that received the greatest amount of community-based advocacy were Sebastian (protection against plague and pestilence) and Gregory of Nazianzus (vine pests). Other saints featured less prominently than Sebastian and Gregory, but still in significant numbers, such as Anne and Roche (both plague), Blaise (throat ailments), Catherine of Alexandria (plague, pests, and locusts), Antony the Great (cattle disease), Agatha (climatic conditions), and Pantaleon (vine pests). ${ }^{200}$ This tendency also manifested in the answers provided to Philip II's questionnaire for eighty communities within the Province of Madrid. Forty-four communities advocated for Sebastian, while thirty-four advocated for Gregory of Nazianzus. Other prominent saints in this region, advocated by six to fourteen communities, were Catherine of Alexandria and Agatha (six communities each), Blaise (eight communities), Antony the Great (nine), Anne (ten communities), and Pantaleon (fourteen communities). ${ }^{201}$ Meanwhile during 1597, Philip II proclaimed that devotion to saints should persist amongst the people of Madrid. The city "desir[ed] to calm [God's] wrath" by adopting "the saints, his friends as our advocates and our defenders"; in this case, they selected Anne and Roche as Madrid's "patrons and advocates in the presence of God, placating the divine wrath [we] have so justly

\footnotetext{
${ }^{200}$ Rawlings, 90.

${ }^{201}$ Relaciones histórico-geográfico-estadísticas, 1:8-738. I reviewed all 252 towns in the Province
} of Madrid that responded to Philip II's questionnaire. Here are a couple examples: Ibid. 79, 373. The community of Aravaca observe the "dia de San Gregorio Nacianceno se guarda por devocion del pueblo, e que guardan las dichas dos fiestas de San Pantaleon e San Gregorio por voto del escarabajuelo e arrevolvedor de las viñas, e San Pantaleon cupo por suerte que echaron en el dicho lugar." Or the community of Meco, "se guarda, y tienen voto de holgar el dia de señor San Sebastian y Nuestra Señora de la Concebcion, y que han oido decir a personas antiguas que se voto por pestilencia que hubo en la dicha villa...y que asimismo se huelga el dia de San Gregorio Nacianceno en la dicha villa, y se hace procesion por el pueblo, y han oido decir que se huelga por voto que se hizo por el mucho escarabajuelo que habia en las viñas, que se las comian al tiempo que echan el fruto." 
merited. ${ }^{202}$ Saints in books and as objects of veneration occupıed a notıceable place with the darly lives of Spaniards ${ }^{203}$

References from hagiographies appeared in correspondence and other writıngs. For instance, in María de Guevara's Desengaños de la corte, y mujeres valerosas (1664), she used the depictions of exemplary saints in the Flos sanctorum This essay counseled the eventual Charles II on increasing the status of Spain in Europe On charity, she wrote "one must imitate those who have had it, such as a certain Saint Isabel, queen of Hungary, whose alms were so great that she had to be restrained." ${ }^{204}$ For describing penitence, she advised "Saint Onofre left the empire and went out to the desert to do penance" and "Saint Jerome left his cardinal's hat and went to the desert to strike his breast with a rock, disillusioned with the world." ${ }^{205}$ Visual representations of saints also borrowed from hagiographical accounts An example appeared in Miguel de Cervantes's novel Don Quixote. When Don Quixote and Sancho Panza interacted with the transporters of saintly images, Quixote knew the saintly narratives of Saints George, Martin of Tours, James the Great, and Paul from memory indicating the pervasive

${ }^{202}$ Quintana, fol 385 “deseando aplacar su 1ra, juzgamos por medıo mas conueniente tomar los Santos, y amigos suyos por abogados, y defensores nuestros, y assi mouldos de particular confidencie, y deuocion que tenemos con la gloriosa Señora S Ana madre de la Virgen santıssıma Marıa madre de Dıos, y Señora nuestra, y al Glorıoso S Roque, cuyos contınuos mılagros nos han mostrado lo mucho qué ante la diuna Magestad puede su intercession, humildemente les suplicamos sean nuestros patronos y abogados en la presencia de Dios, aplacando la diuina ira tan justamente merecida " Underlıned sections featured in the above passage

${ }^{203}$ Saints were signifiers of community identities in sixteenth and seventeenth-century Spain, see José Ignacio Gómez Zorraquino, "Los santos patrons y la identidad de las comunidades locales en la España de los siglos XVI y XVII," Revista de Historia Jerónimo Zurtta 85 (2010)· 39-74

${ }^{204}$ Maria de Guevara, "Desengaños de la corte, y mujeres valerosas," in Warning to the Kings and Advice on Restoring Spain A Bulingual Edition, ed and trans Nieves Romero-Diaz, 64-111 (Chicago and London University of Chicago Press, 2007), 104-5 The quoted text is Romero-Diaz's translation The orıginal "imıtando en la carıdad a muchos, que la han tenıdo, como una S Isabel Reına de Hungría, que eran tantas las limosnas que hacía, que se las moderarton"

${ }^{205}$ Guevara, 106-7 The original "S Honofre dejo el Imperio, y se fue a hacer penitencia al desierto" and "S Jeronımo dejo el Capelo, y se fue al desierto a darse en los pechos con una piedra, desengañado del mundo" 
character of such accounts. ${ }^{206}$ The perceptions of santhood found within Flos sanctorum and other hagiographical collections were highly visıle in early modern Spanish books and society

Teresa of Avila offered some insights into this phenomenon. During her canonisation proceedings, one of the reported miracles was the cure of one of Teresa's servants through their devotion to a fragment of Teresa's writings. ${ }^{207}$ A saint's curative properties transferred to a relic, a piece of paper stained with ink. Hagiographical literature played a prominent role in Teresa's spiritual life and was a motivator for her to recommit to her religious life: "I therefore did not read [most books], but only the lives of saints. As I find myself so lacking to their service to God, [these saints' lives] seem to encourage and revive me. ${ }^{208}$ Not surprisingly, Teresa chose a Flos sanctorum for quotidian reading by the Discalced Carmelites. ${ }^{209}$

The correlation between earthly existence and the implementation of saintly virtue into Teresa's life deepened through discussing specific exemplars. On temptation during prayer, Teresa directed her readers to follow the example of Jerome: "Ignore the bad thoughts. Look also at those thoughts the devil placed into St Jerome['s mind] in the

${ }^{206}$ Miguel de Cervantes Saavedra, Don Quyote de la Mancha (Madrıd: Cupsa Editonal, 1977), 1017. "Y levantándose, dejó de comer y fue a quitar la cubırta de la primera imagen, que mostró ser la de San Jorge puesto a caballo, con una serpiente enroscada a los pies y la lanza atravesada por la boca, con la fiereza que suele decirse Descubrióla el hombre, y pareció ser la San Martín puesto a caballo, que partía la capa con el pobre. Rióse don Quıjote y pidıó que quitasen otro henzo, debajo del cual se descubrió la ımagen del Patrón de las Españas a caballo, la espada ensangrentada, atropellando moros y pisando cabezas . Luego descubrieron otro lienzo, y pareció que encubría la caída de San Pablo del caballo abajo, con todas las circunstancias que en el retablo de su conversión suelen pintarse "For comparatıve purposes, I used the following English translation* Miguel de Cervantes Saavedra, The Ingenious Hidalgo Don Quixote de la Mancha, trans. John Rutherford (London. Penguın, 2003), 874-5.

${ }^{207}$ Bouza, Communication, 38

${ }^{208}$ Teresa de Ávila, Libro de la vida (Madrıd Taurus, 1982), 220 “y así no los leía, sıno vidas de Santos, que, como yo me hallo tan corta en lo que ellos servían a Dios, esto parece me aprovecha y anıma."For comparatıve purposes, I used the following Englısh translation Teresa of Ávila, The Life of Saint Teresa of Avla by Herself, trans. J M. Cohen (London Pengun, 1957), 219.

${ }^{209}$ Egido, 64 
desert. ${ }^{1210}$ On general sanctity, she directed her readers towards the exemplars found in saints' lives:

Blessed is he who truly loves Him and always has Him by his side. Let us look at the glorious St Paul, from whose mouth [the name of] Jesus was never absent and who held it within his heart After I understood this, I have looked carefully into [the lives] of sants that were great contemplatives and they did not travel by another road St Francis portrays it through his wounds [his stigmata], [as does] St Anthony of Padua, St Bernard took delight in humanity, so did St Catherine of Siena, [as well as] many others that you, Lord, will know better than me. ${ }^{211}$

While modelling her behaviour upon the saints found in hagıgraphies, Teresa continued to venerate these intercessors as a route towards God. ${ }^{212}$ Teresa's treatment of saints as superlative embodiments of Christian virtue in addition to active intermediaries between God and the natural world was typical of early modern Spanıards Hagiographies disseminated these ideals through printed books.

Hagiographies represented an ideal religious life to Catholics. During and after Trent, saints and their lives experienced a normalisation. ${ }^{213}$ After Trent, parishes ideally adhered to centralised orthodoxy, while at the same time the papacy insisted that the parish was the centre of religious life. Canonisation halted abruptly with the Reformation

210 Teresa de Ávila, 101 "No haga caso de malos pensamientos Mire que también los representaba el demonio a San Jeronimo en el desierto " $\mathrm{Cf}$ Teresa of Avila, 80

${ }^{211}$ Teresa de Ávila, 165-66 "Bıenaventurado quien de verdad le amare y siempre le trajere cabe sí Miremos al glorioso San Pablo, que no parece se le caía de la boca siempre Jesús, como quien le tenía en el corazón Yo he mirado con cuidado, después que esto he entendido, de algunos santos, grandes contemplativos, y no iban por otro camino. San Francisco da nuestra de ello en las llagas, San Antonio de Padua; San Bernardo se deleitaba en la Humanıdad, Santa Catalına de Sena otros muchos que vuestra merced sabra mejor que yo " Cf Teresa of Ávila, 156

212 Teresa de Ávila, 193 "Tomaba santos devotos porque me librasen del demonıo Andabas novenas, encomendabame a San Hilarıón, a San Miguel Ángel, con quien por esto tomé nuevamente devocion, y otros muchos santos importunaba mostrase el Señor la verdad " Cf Teresa of Ávila, 187

${ }_{213}$ Cameron, 219-39, Certeau, The Mystlc Fable, $1242-51$ Certeau emphasises the increased normalisation (Certeau institutionalisation) of the Society of Jesus, evident in the devotional works becoming "less affective, more technical" (250) Certeau states this process is evident in the Society's depiction of Ignatius "as in the iconography in which the knight, the pilgiım, the refoimed priest wearing the Roman habit, and episodes similar to the Flos sanctorum were replaced by a founder in priestly robes, bearing like a monstrance, the texts of a law inspired by God The institution had become the true founder Whatever remained of the primitıve 'miracles' was there to prove that that institution was of 'our' spırıt" (251) 
Between 1523 and 1588, not a single saint and after 1588, no theologian and few martyrsaints underwent canonisation by the Roman Church. The majority of newly minted saints were male, Italian or Spanish, and noble clerics. These saints were most often founders of religious orders, missionaries, and pastors, which emphasised the Tridentine ideals of institutional organisation and proselytisation to heretics. ${ }^{214}$ Continued devotion to saints persisted, which manifested in either the creation of new cults or the resurrection of dormant civic cults of already-extant saints, such as Segovia's veneration of the eighth-century Castilian hermit, Fructus, or Ávila's devotion to the first-century missionary and martyr, Secundus of Abula. At the same time, holy persons not officially recognised by the Church assumed a similar place to saints in the local religious practices of Spaniards. Occasionally, these 'saints' received recognition and underwent canonisation. Examples of figures of local devotion that underwent canonisation included Julian of Cuenca (canonised 1594) and Isidore the Labourer for Madrid (canonised $1622) .^{215}$

The scouring of the hagiographical tradition initiated amidst the Council of Trent increasingly required textual sources verifying saintliness. Sainthood was not contingent on canonisation, but rather on the perpetuation of the memory of a saint's miracles and exemplary religiosity. Local cults did not depend on written confirmation, but on continued veneration. On the other hand, an officially recognised saint had to have some historical basis through evidence, whether saints' lives or sermons. All the saints we met

\footnotetext{
${ }^{214}$ Burke, "Counter-Reformation Saint, 131-39. During that time, however, unofficial cults were recognised. Ditchfield, "Coping with the 'Beati Moderni"" 419 n. 23.

${ }^{215}$ Sara T. Nalle, "A Saint for All Seasons: The Cult of San Julián," in Culture and Control in Counter-Reformation Spain, eds. Anne J. Cruz and Mary Elizabeth Perry, 25-50 (Minneapolis and Oxford: University of Minnesota Press, 1992), 26. The remainder of Nalle's essay examines this revival and the canonisation of Julian of Cuenca.
} 
above had hag1ographers: Secundus had Antonio de Cranca, Fructus had Juan de Horche, and Julian had several. ${ }^{216}$ Ribadeneyra's printer Sánchez printed Cianca's life of Secundus in $1595 .{ }^{217}$ Some of the printers of lives of Julian, most notably Toledo's Pedro Rodríguez and Cuenca's Juan Masselin, also printed Flos sanctorum. ${ }^{218}$ Focussing on Madrid's Isidore, Villegas wrote a sacred biography, while Lope de Vega composed an epic poem ${ }^{219}$ As such, canonisation and hagiographical literature certıfied saints long reverred in cults, but they did not create these exemplary figures

Ecclesiastıc authorities, however, maintained that Spanish Christians were not to believe in mythical and exaggerated aspects found in some saints' lives. The Toledan Provincial Councl of 1565 and 1566 in its direction to preachers promoted a hybrid of tradition and reform

Remind the people of the ecclesiastical customs, rites, and ceremonies that the Catholic Church uses they must abstain, however, from the [excesses] of fabulous stories, but they should not stop referring to the true [accounts] of the martyrs and the saints, admitted by the common consent of the Church. ${ }^{220}$

${ }^{216}$ Nalle, "Saint for All Seasons," 45 n 3, 48-50 The hagiographies mentioned are Antonio de Cianca, Historia de la vida, invención, milagros, y translación de San Segundo, primero obsipo de Avila (Madrid Luıs Sanchez, 1595), Juan de Horche, Historia de la vida de San Frutos, patrón de la Ciudad de Segovia y sus hermanos San Valentín y Santa Engracia (Valladolid C Lasso Vaca, 1610) Julıan's hagıographers include Francisco Escudero, Baltasar Porreño, Bartolomé de Segura, and J B Valenzuela Velázquez

${ }^{217} B M 469$

${ }^{218}$ Masselin printed parts of Villegas's Flos sanctorum in 1593 and 1594, Rodríguez produced volumes of the same complation in 1583, 1588, 1595 Rodríguez's father, Juan, began printing Villegas's Flos sanctorum in 1582 Consult Appendix 1, under BM 423 and 424, $I B$ 19547, 19551, 19566, 19596, 19602 , and 19605.

${ }^{219}$ Alonso de Villegas, Vida de Isıdro Labrador, cuyo cuerpo está en la iglesia parroquial de San Andrés de Madrd (Madrıd Luıs Sanchez, 1592), Lope de Vega Carpı, Isıdro (Madrid Lus Sánchez, 1599)

220 "Concılıo Provincıal de Toledo, año 1565 a 1566 Sesión III - De Reforma," in Colección de los Cánones y de todos los concllos de la Iglesia de España y América, ed Juan Tejada y Ramıro, 5 24360 (Madrid Pedro Montero, 1863), 5245 "Recomienden el pueblo las costumbres eclesiásticas, los ritos y las ceremonias que usa la 1glesıa catolica Absténganse, sin embargo, de las historias fabulosas, pero no dejen de referır oportunamente las verdaderas de los martıres y los santos, admitidas por común consentimiento de la iglesia" 
Such criticisms manifested in Don Quixote. A priest took exception with the distortion and manipulation of saintly narratives in religious plays:

Well, how about religious plays? What false miracles they invent, what apocryphal and misunderstood things they possess, attributing to one saint the miracles of another!...all to the detriment of truth and the undermining of stories, and even reproachful towards Spanish writers. ${ }^{221}$

Spanish Catholics continued to venerate saints and read hagiographies, but increasingly had little patience with pious fictions, however well-intended.

In Spain during the late-sixteenth century, hagiographers accounted for these criticisms and reformed saints' lives. By then, two types of Flos sanctorum appeared in print. One remained closely related to the Legenda aurea tradition such as Pedro de la Vega's Flos sanctorum, which had intermittent publication between 1516 and 1580 . Vega's redaction had no printings between 1558 and 1568. After the 1572 edition from Alcalá based on the 1558 text, printers from Seville produced all subsequent editions. ${ }^{222}$ The second trajectory emerged from Luigi Lippomano and Laurentius Surius's school of hagiography. As an Italian cardinal, hagiographer, and participant at Trent, Lippomano used his compilation to provide spiritually edifying saints' lives that expressed Catholic orthodoxy. Lippomano considered his collection an important confessional weapon; it included an inventory aimed at contemporary anti-Protestant polemic: "A catalogue of those things in the following saints' lives which uphold the truth of Catholic teaching

${ }^{221}$ Cervantes, Quijote, 524. "Pues ¿qué, si venimos a las comedias divinas? ¡Qué de milagros falsos fingen en ellas, qué de cosas apócrifas y mal entendidas, atribuyendo a un santo los Milagros de otro!...que todo esto es en perjuicio de la verdad y en menoscabo de las historias, y aun en oprobio de los ingenios españoles." Cf. Don Quixote, 445-46.

${ }^{222}$ Aragüés Aldaz, "Tendencias y realizaciones," 512-3, 521. Vega's Flos sanctorum had printings in $1516,1521,1540,1541,1544,1548,1551,1558,1568,1572,1578,1580$. 
and, as it were, fortify a powerful bulwark against the heretics of our time." ${ }^{223}$ The index enumerated points of Catholic doctrine that had met with Protestant objections such as good works, purgatory, the papacy, and saints themselves The insistence on doctrinal orthodoxy was abundantly evident in Lippomano's declaration that his collection included "expositions ..to crush the blasphemies and delusions of all contemporary heretics." By the time of the third volume's publication, Lippomano could note that it contained "the usual expositions against the madness of contemporary heretics." "224

Surıus, meanwhıle, was a German Carthusıan monk and hagiographer who revised Lippomano's works. He sought to affirm the hagiographical genealogy he shared with Lippomano and the necessity of affirming the authenticity of saints' lives:

On the true histories of the Saints, some from the volumes of Luig1 Lippomano, a very learned bishop, some from exceptional manuscript books, many of which having never before been published, are now collected together with the utmost faithfulness 225

At the same time, Surius included miracles stories within his redaction of saints' lives as an indication of the continued relevance of venerating them as intercessors. After the official church resumed their recognition of sainthood in 1588, saints' miracles served as evidence in their trials for beatification and canonisation. Lippomano and especially Surius initiated a new approach to Catholic hagiography that asserted confessional

${ }^{223}$ Lippomano, 1 sig a $1 \mathrm{r}$ "Catalogus earum rerum quae in sequentibus sanctorum vitis contra haereticos nostrı temporis pro catholicorum dogmatum ueritate astruuntur, atque velutı robustissimıs propugnaculis fulciuntur"

${ }^{224}$ Lippomano, 1. sig. A 1r, 2 sig a 1 r, 3 sig a $1 \mathrm{r}$ The subtitle from volumes one and two is "cum Scholıs elusdem omnium praesentıum haeretıcorum blasphemias et delyramenta profligantibus" Volume three, meanwhile, read "cum solitıs scholıs aduersus praesentium haeretıcorum insanıas" The remaining five volumes use variants from volumes one, two, or three

${ }^{225}$ I could not find copies of the original editions of Surius printed in Cologne between 1570 and 1575, but I found their title here Francis J Thomson, "The Popularity of Peter Skarga's Lives of the Saints," in For East is East Liber amicorum Wojclech Skalmowsk, eds Tatjana Soldatjenkova and Emmanuel Waegemans (Louvain Peeters, 2003), 124 n 21 "De probatis Sanctorum historiss, partim ex tomis Aloysil Lippomani, doctissimi eptscopi, partim etiam ex egregils manuscriptis codicibus, quarum permultae antehac numquam in lucem prodien, nunc recens optıma fide collectis" 
identity whıle refuting others. Their followers included the Spanısh hagiographers Villegas and Rubadeneyra ${ }^{226}$

Villegas used several titles for his compilation, including: "The Flower of the saints and general history of the life and deeds of Jesus Christ removing any apocryphal and uncertain things" and "The Flower of the saints and general history of the life and deeds of Jesus Christ, God and Our Lord, and of all the saints who are venerated and have a feast day in the Catholuc Church that conforms to the Roman Breviary, reformed by the decrees of the holy Councl of Trent, together with the lives of our saints of Spain, and of other extravagantes". ${ }^{227}$ V1llegas invoked ecclesiastic authority through recalling the Council of Trent and the official edition of the new breviary in 1568. Villegas also localised the collection since it mcludes Spanish saints while integrating Span into Roman Catholıcism. The term extravagantes has numerous meanings in Castilian, but Villegas and later Ribadeneyra use the word to describe saints not officially part of the liturgical calendar or not canonısed. ${ }^{228}$ Ribadeneyra continued Villegas's practice of separating official saints from extravagantes, but removed a section dedicated to Iberian saints. Instead, Rubadeneyra chose to include exemplary Jesuits amongst the extravagantes, a practice that began in 1604 .

$119-30$

${ }^{226}$ Aigraın, 322-28, Aragués Aldaz, "Tendencias y realızaciones," 519-22, Ditchfield, Liturgy,

${ }^{227} I B 19548,19560$

${ }^{228}$ Diccionano de la lengua castellana (Madrid Viuda de Francisco del Hierro, 1732), 3.699 "EXTRAVAGANTE adj Desreglado, sin órden, $\mathrm{n}$ metodo, raro y extraordınarı Lat Irregularis, Inordinatus, Inconsuetus, Exoticus Usado como substantıvo se toma por Constitucion Ecleslástica, ó Canónıca establecida por el Papa, assı dicha porque no estaba reducida, no colocada en el libro de las Decretales Lat Extravagans, Litterae extravagantes Se usa assimismo por el que no es del número, no tıene assientofixo, nı está computado, no incluıdo, ó incorporado con alguna compañıa, comunidad, ó clase de personas, ó estados, sino que libremente obra y exerce por sı y donde quiere su oficio, o cargo Superforaneus, superventens, inassignatus" 
In order to grasp the significance of Ribadeneyra's emphasis on exemplary Jesuits, it is useful to examine the history of the order's development in Spain. The Jesuits had established a noticeable presence in both Madrid and Alcalá by the middle of Philip II's reign. While the early companions of Ignatius were mostly Spaniards, the expansion of the Society in Spain was initially slow with the exception of university cities such as Alcalá. By the 1550s, however, the Society had some presence in Spain's major urban centres, such as Valladolid, Barcelona, Zaragoza, Toledo, and Medina del Campo amongst others. Salamanca, Valencia, and Alcalá accounted for half of the Society's Spanish recruits during Laínez's governorship (1558-1565). ${ }^{229}$ By the start of Everard Mercurian's governorship in 1573, the order had expanded its presence elsewhere in Spain even forming distinct provinces: Aragon (Aragon, Valencia, Catalonia, and Ribagorza), Castile (Galicia, Asturias, Basque Country, Navarre, Leon, and Old Castile), Toledo (New Castile, Extremadura, and Murcia), and Andalucía. For instance, there were consistent provincial populations for Toledo (400), Castile (360), Andalusia (200), and Aragon (150). By 1580, each province's population increased such as Toledo (480), Castile (500), Andalusia (260), and Aragon (200). ${ }^{230}$ By the end of Claudio Acquaviva's tenure (1581 to 1615), the Jesuit population in Spain had grown again: for instance, Toledo (570), Castile (613), Andalusia (600), and Aragon (390). ${ }^{231}$ While composing the Flos sanctorum, Ribadeneyra wished to integrate the Society into a confessional community through life-writing, whether on Ignatius, Borgia, Laínez, or the saints in the Flos sanctorum. Ribadeneyra never left Spain after the 1570s, but his earlier travels contributed to his use of hagiography as a rebuttal to Protestantism in the age of

\footnotetext{
${ }^{229}$ Astrain, 2:39-103; O'Malley, First, 52-55.

${ }^{230}$ Astrain, 3:178-79.

${ }^{231}$ Astrain, 4:753-54.
} 
confessionalisation, akin to what Surius and Lippomano had done in the 1560s and 1570s. Ribadeneyra refuted heresy through the lives that he wrote of a cavalcade of imitable and Catholic saints as Surius and Lippomano had done previously. Ribadeneyra, however, was also an avid reader of Surius, Lippomano, and other writers that contributed to his conception of a confessional community of readers that he promulgated in his Flos sanctorum. 


\section{CHAPTER 2: 'TOLLE, LEGE' AND CATHOLIC COMMUNITY}

Ribadeneyra's Flos sanctorum allowed its readers to incorporate not only the behaviour of the saints described, but also his practices as a hagiographer As a writer of saınts' lives and the translator of Augustıne's Confessions, Rıbadeneyra was well aware of the impact of reading upon Augustıne's religious development ${ }^{232}$ In one memorable instance, Augustıne heard a child's voice imploring him to read the Gospel

Augustine heard a voice singing that said and repeated many times "Take it and read, take and read" He took the book, understanding that God had sent it to him, opening 1t, he read the first chapter that he found In reading this sentence [Romans 13 13-4], a ray of light penetrated Augustine's heart, and all the darkness of his doubts vanished, and he was so changed, that he says the same with these words But by chance were I asked, why am I writing about the virtues and examples of the sants so that we may imitate them, have I written here about the vices and errors which in his youth Augustine had done, as these things should not be imitated, but loathed and detested? To this I respond, that I have done this in order to imitate St Augustine himself, who in the book of his Confessions portrays his life In it, he provides a picture of his habits and vices, he cries over them, and he asks the Lord to forgive them 233

Ribadeneyra not only related the 'tolle, lege' episode from Augustine's Confessions, but also inserted himself into the narrative as an imitator of Augustıne through recalling his virtues and his sins Ribadeneyra recreated within his text an act of contrition, which remained part of Catholic and Protestant devotional life ${ }^{234}$

\footnotetext{
${ }^{232}$ On reading and Augustıne's Confessions, see Stock, 23-121

${ }^{233}$ Rubadeneyra, Flos (1601), 264 "Oyo vna voz con vn cantar, que dezıa, y lo repetra muchas vezes Toma y lee toma y lee Tomo el libro, entendiendo q[ue] Dios se lo ma[n]daua, abriole, leyo el prımer capitulo que hallo En leyendo esta sentencia, vn rayo de lux penetro el coraçon de Agustın, y todas las timieblas de sus dudas desaparecieron, y quedo tan trocado, que el mismo dize de sı estas palabras Pero por ventura alguno pregu[n]tara, porque escriuie[n]do yo las virtudes y exemplos de los santos, para que los 1mitemos, he escrito aqui los vicios y errores, que en su mocedad tuuo san Agustin, los quales no se deuen imitar, sino aborrecer y detestar? A esto respondo, que lo he hecho principalmente, por imitar al mismo san Agustin, que en el libro de sus confessiones pinta su vida, y haze vn dibuxo de sus costumbres y vicios, y los llora, y pide de [e]1los perdon al Señor" See also Augustıne, Confessions, trans R S Pıne-Coffin (London Penguin, 1961), 177 The entire account is the culmination of Book 8 in the Confessions

${ }^{234}$ Please consult the following on the use of exempla Aragues Aldaz, Deus concionator, Peter Burke, "Exemplarity and Anti-exemplarity in Early Modern Europe," in The Western Time of Ancient History, ed Alexandra Lianerı (Cambridge Cambridge Unıversity Press, 2011), 48-59, Nigel F Palmer,
} 
Reading contributed towards an early modern Catholic community centred on the behavioural models found in these Catholic books after Trent. For Ribadeneyra, the acquisition of saintly exemplars in the Flos facilitated devotion, while reinforcing the concept of a Catholic community. At the same time, the hagiographical compilation served as a manual for subsequent hagiographers. After Ribadeneyra's death in 1611, the Jesuit Cristóbal López wrote in his life of Ribadeneyra that:

Such was his devotion to Christ our Lord and his holiest Mother as well as to the saints and angels that no day passed without him reading their histories, and afterwards he avidly reviewed what he had noted down of their virtues, taking from them the fruit needed to imitate them. And before he could write the Flos sanctorum, he read every day the Roman Martyrology; and after that, Cardinal Baronius's Annotatıons of it. Looking at the authors that the Cardinal had cited, it was apparent that the Cardinal had published the fruit of his devotion, as Ribadeneyra himself would later publish his lives, wellwritten and composed with such devotion, discretion, truth and wisdom. ${ }^{235}$

While writing was part of Ribadeneyra's piety, the imitation of the devotional reading of saintly works animated Ribadeneyra when he compiled the Flos sanctorum.

Akin to the genealogy of sanctity evident in his saints' lives, Ribadeneyra traced the lineage of religious writing from its inception in the apostolic church. He placed himself as both a hagiographer and a reader of saints' lives within this geneology. Saints possessed imitable conduct that they acquired in part through observing exemplary

\footnotetext{
"Exempla," in Medieval Latı, eds. F A.C. Mantello and A.G. Rigg (Washington, D.C.: Catholıc Unıversity of America Press, 1999), 582-88.

${ }^{235}$ Cristóbal López, "Vida del Padre Pedro de Ribadeneyra, Religioso de la Compañía de Jesús. En Madrid año de 1612" in Pedro de Ribadeneyra, Confessiones, eptstolae, altaque scrtpta tnedita, ed. Daniel Restrepo (Madrid: La editorial Ibérıca, 1923), 2: 460. "Fue su deuoción con Christo nuestro Señor y su Madre sanctíssima y con los sanctos y angeles de manera que nungun día se le passaua sin leer sus historias, y contaua despues con mucho gusto lo que auía notado de sus virtudes, sacando dellas el fruto que se ha de sacar para ymitarlas. Y antes que escriuiesse los Flos sanctorum, leía cada día el martyrologıo romano; y despues quel cardenal Baronıo hizo las annotaciones del, miraua los auctores quel cardenal alegana, que parece fue fructo desta su deuoción el sacar a luz, como despues sacó, sus vidas tan bien escritas y con tanta deuocion, discreción, verdad y prudencia."
} 
behaviour of others ${ }^{236}$ The Flos sanctorum provided the devout with accounts of saintly virtue that they could implement into their own lives, for example in prayer ${ }^{237}$ Through reading and writıng the history of Catholicism, Ribadeneyra constructed a confessional communty onented around cyclical exemplars of sainthood This hagiographer's library was a collection of works that delineated the orthodoxy, tradition, and imagined unıversalısm of early modern Catholıcısm ${ }^{238}$ It also situated his efforts as a hagiographer withın a larger traditıon of writıng saints' lives and sacred history

\section{Towards a History of Reading in Early Modern Spain}

Ribadeneyra's reading habits were those of a priest born into the minor nobility In early modern Spain, nearly all the clergy, qualified bureaucrats, merchants, the upper nobility (which excluded hidalgos) were literate, while only a third to half of the artisans, shop-keepers, and nicher farmers could read ${ }^{239}$ On average, however, the literacy rate was approximately ten to fifteen percent These percentages increased in cities, whereas towns and villages with less than 500 households had lower rates of literacy ${ }^{240}$ Men had a higher rate of literacy than women by the end of the sixteenth century, half of the male population was literate ${ }^{241}$ While European Protestants had higher literacy rates, the discrepancy between the estımates based on confessional lines has often been

${ }^{256}$ Ibid 472 "se hecha de ver esta discrecion en las vidas de los sanctos del Flos sanctorum de ambas partes, porque sabe aprobecharse de lo mas a proposito dellas y que mas puede edificar las almas de los que las leen, y dexar lo que le parece menos ymitable y que puede aprobechar menos Y lo mismo se vee en las vidas de nuestros sanctos Padres Ignacio, Laynez y Borja"

${ }^{237}$ Lopez, 483 "Hizo el Manual de oraciones para si y para la gente deuota, en el qual resume las vidas de los mas de los sanctos del Flos sanctorum, pidıendo a Dios sus virtudes"

${ }^{238}$ Compare with Chartier's conception of the library without walls Chartier, Order, 61-88

${ }^{239}$ R A Houston, Literacy in Early Modern Europe (New York and London Longman, 1988), 131

${ }^{240}$ Houston, 140-41

${ }^{241}$ Nalle, "Literacy and Culture", 67-72 Also compare, Prieto Bernabe, 1333 
exaggerated. ${ }^{242}$ The rates between confessions were proportional, but locality influenced the ability to read and write more than confession

Reading and writing were integral to Ribadeneyra's religıous vocation In the Imitation of Christ, a good religious should never be "entirely idle, but reading or writing, in prayer or in meditation, or else be engaged in some work for the common good.,243 Flos by Villegas or Ribadeneyra featured extensively in the libraries of clergy ${ }^{244}$ For instance, Antonio de Riaño y Viedma, the parish priest of Madrid's St Michael, had the Flos of both Villegas and Ribadeneyra. ${ }^{245}$ These texts, however, were not economical, yet this expense did not prevent their widespread use. ${ }^{246}$ In comparison, the cost of Surius's compilation was accessible only to the wealthy, but it was a source frequently consulted by sermon writers ${ }^{247}$

Other popular works of religious literature in Golden Age Madrid included the Bıble, Missals, Breviaries, Books of Hours, as well as the works of Teresa of Ávila, Luis de Granada, Augustıne, and Bonaventure ${ }^{248}$ Other than the Bible, Catholic clergy gravitated towards catechisms, confessional manuals, commentaries and sermons by the

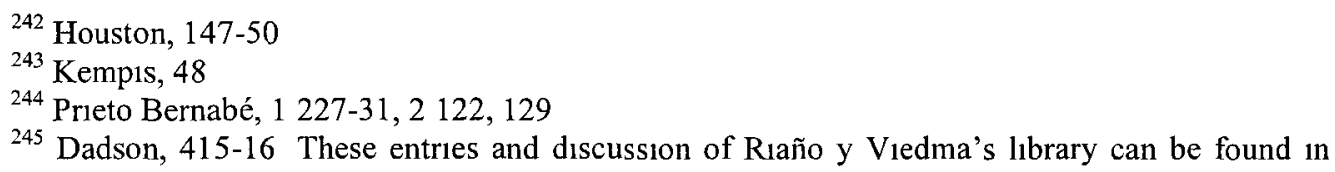
Dadson, 215-36, 416-17

246 Dadson, 415-17, 470-71, 475-78, 480, 485-86, 488, 490, 497, 504, Marcelin Defourneaux, Dally Life in Spain in the Golden Age, trans Newton Branch (London George Allen and Unw1n, 1970), 233-34 The numbers are estimates and betray the expense of some books For most of the seventeenth century, Villegas's Flos averaged around twenty reales if unbound for the work's first volume Ribadeneyra's work was only a few reales less expensive, averaging around fifteen reales The costs skyrocketed if the book was to be bound As a devotional book, it was a luxury compared to others of its kınd, especially when a liveable but sparse daily income was approximately two-and-a-half reales

Since the book inventories found in Dadson occasionally employ different monetary denominations, I w1ll state the exchanges I have used The base unit of coinage in Castıle is a maravédi The other units featured in Dadson were the ducat (=375 maravédıs) and the real (=34 maravédıs) A ducat is about equal to eleven reales In comparison, unbound saints' lives not by either Villegas or Ribadenerya cost between two and five reales, while a reader paid three reales for a loose-leaf Imitation of Christ

${ }^{247}$ Ditchfield, Liturgy, 126
${ }^{248}$ Prieto Bernabé, 1 200-27 
Church Fathers, the Imitation of Christ, and saints' lives Meanwhile, the laity preferred the Imitation, Books of Hours, catechisms, and collections of sermons ${ }^{249}$ The most piominent owners of religious books were booksellers, bureaucrats, nobles, and clergy 250 While the majority of the books owned by clei1cs were religious, their libraries also had numerous volumes of history, law, and other genres of writıng, such as fiction, essays, poetry, and drama ${ }^{251}$ Religıous books drifted between three prevalent and porous audiences of reading early modern clerical readers of religious books desired works of piety and devotion (as did the laity), texts for ecclesiastic professionals, such as liturgical manuals or apologetics, and works for broad audiences that discussed contemporary religious and political conflicts and affairs ${ }^{252}$

Trends in readership require more than the review of libraries' holdings A sixteenth-century Premonstratensıan Spanısh frıar, Tomás Quxada, remarked that

I do not go looking in the libraries

Of Archbishops, Dukes, or Marquises, For boastıng's sake assembled, just for looks, Since rarely do their owners ever read their books ${ }^{253}$

In addition, items from institutional and individual libraries only tell a fraction of the story At home, books read aloud offered spiritual comfort and entertainment Yet we cannot understate the religious element of reading since it enables another way of sharing

${ }^{249}$ Julia, 243-44, 251-66

${ }^{250}$ Prieto Bernabe, 1198

${ }^{251}$ Prieto Bernabe, 2102

${ }^{252}$ Paul Nelles, "Three Audiences for Religious Books in Sixteenth-Century France," in The Sixteenth-Century Religious French Religlous Book, eds Andrew Pettegree, Paul Nelles, and Philip Conner (Aldershot Ashgate, 2001), 256-85

253 Tomas Quixada, "Consulta," in Bartolome Villalba y Estaña, El Pelegrino Curnoso y Grandezas de España (Madrıd Miguel Ginesta, 1886), 168 I used thıs translation due to its pithıness Bouza, Communication, 65 "Que no me ando a buscar las librerias, / de Arzobispos, ni Duques, nı Marquesses, / que las tienen por sus fanfarronias / y leen en los libros pocas vezes," 
the 'fruit' of Christian piety. ${ }^{254}$ Teresa of Ávila's Autoblography discussed reading saints'

lives aloud. In her youth, she and her siblings would gather

we used to read the lives of saints together... as I saw the martyrdoms that the saints endured for God, it appeared to me that they bought therr passage to God very inexpensively. I wanted so much to die, not for any comprehensible love, but to acquire as rapidly as they had the great joy in heaven that I saw. 255

As found in Teresa's account, older brothers introduced the genre of saints' lives to female readers, a tendency echoed in the life-writing relationship between male confessors and female penitents. ${ }^{256}$ Sites of reading were not only libraries, but also public spaces as well as homes ${ }^{257}$

Another public space for reading was bookstores. For instance, Francisco de Quevedo addressing the reader of The Swindler admonished persons who read a book

${ }^{254}$ Chartier, "Leisure and Sociability," 104-6, 113-14, tdem, "Readıng Matter and 'Popular' Reading," 276-78

${ }^{255}$ Teresa de Ávila, 47-48 "juntabamonos entrambos a leer vidas de santos Como veía los martirıos que por Dios las santas pasaban, parecíame compraban muy barato el ir a gozar de Dios y deseaba yo mucho morır así, no por amor que yo entendiese tenerle, sino por gozar tan en breve de los grandes bienes que leia haber en cielo " Cf Teresa of Avila, 23-24

${ }^{256}$ On the relationship between confessors and penitents, see Bilınkoff, Related Lives The trope of the older brother reading a saint's lıfe appears in a manuscript life of Lucía de Jesús, cited from Antonıo Castillo Gomez, "La biblioteca interıor" experiencias y representatciones de la lectura en las autobiografias, memorias, y diarıos del Siglo de Oro," in La Memorta de los libros, eds Pedro M Cátedra and María Luısa López-Vidniero (Salamanca Instituto de Historia del Libro y de la Lectura, 2004), 223 "Olvidaseme de decır que en este mesmo tiempo y edad supe milagrosamente leer y escribır sin que nadie me enseñase [ ] En ocasión que el hermano mayor estaba leyendo en un Flos santorum para que le oyéramos los demás, y de que acabo de leer, dıje yo "Mas, ¿Qué vuelvo yo a leer lo que mi hermano ha leído?” Rıéronse de mí, diciendo que quitase allá, que cómo podía ser aquesto que yo decía Yo porfié a que me diesen el libro [ ], y leí con mucho desenfado lo que había prometıdo, y en otra cualquier parte de aquel libro o en otro cualquierıa. Pero nı por eso me daban crédito, antes me decían lo tenía de cabeza y que hacía que lo leía Yo, para verificar más esto, le pedía a un vecıno que me diese lección, diciéndole que me enseñase [ ] Hízolo a mi petición y viose que yo lo sabía [ ], quedando muy admirado, pero no haciendo de ello misterıo milagroso Debı́ de parecerles gracia natural, y a mí también me parecía lo mismo, no discurriendo más"

${ }^{257}$ Richard L Kagan, Lucrecia's Dreams Polttics and Prophecy in Sixteenth-Century Spain (Berkeley, CA, Los Angeles, and London Unıversıty of Calıfornıa Press, 1990), 23 -25 Kagan discusses the rich visual and aural culture of early modern Madrıd through the prophetess Lucrecia de León While the extent Lucrecia could read and write is not certain, she was knowledgeable about Spanish history (the Cid, Roderic, Charles V, Isabella and Ferdinand) and even Roman mythology. A lack of proficiency at reading and writıng does not suggest a culturally illiteracy, but she "learned a greal deal by keepıng her eyes and ears open" 
piecemeal: they read fragments of a book at a bookstore and eventually read the entirety of the work without buying it. ${ }^{258}$ Inventories of printed books also frequently farled to account for manuscripts, of which a rich culture existed in Golden Age Spain. ${ }^{259}$ Lope de Vega depicted this phenomenon, while criticising printing in "Fuenteovejuna":

Barıldo: Leonelo, printing is important

Leonelo: Without printing, many centuries have passed, and we do not see in this age of print

a St Jerome, or an Augustine emerging. ${ }^{260}$

Lope de Vega, through Leonelo, insinuated that print has not produced a writer of the same magnitude as Jerome or Augustine. ${ }^{261}$ An investigation of reading, therefore, required not only study of data from library inventories, but also a consideration of other sites of reading.

Reading silently, akin to Augustine's depiction of Ambrose in the Confessions, was a medieval practice that persisted after the advent of print. ${ }^{262}$ While both silent and audible reading contributed to a sense of Catholic community, they secured this identity in different ways. Pondering over texts in silence encouraged prayer, meditation, and self-examination, whereas audible reading encouraged community through shared

${ }^{258}$ Francisco de Quevedo, La vida del Buscón llamado Don Pablos (Salamanca: Consejo superior de investıgaciones cientıficas, 1965), 7. "Qve desseoso te considero Lector, o oydor (que los ciegos no pueden leer) ..pues ya le tienes en tu casa, sino es que en la del Librero le hojeas, cosa pesada para el, y que se auıa de quitar con mucho rıgor, que ay gorrones de libros, como de almuerços, y hombre que saca cuento leyendo a pedaços, y en diuersas vezes, y luego le zurze"

${ }^{259}$ Bouza, Corre, 27-83.

${ }^{260}$ Lope de Vega, "Fuenteovejuna," II, i, lınes 927-31. "Barıldo Leonelo, la impresión es imporante. / Leonelo Sin ella muchos siglos se han pasado, / y no vemos que en éste se levante / [blank lıne] / un Jerónımo santo, un Agustıno "I used the following editıon· Lope de Vega Carpıo, Fuenteovejuna, ed Donald McGrady (Barcelona. Crítıca, 1993)

${ }^{261}$ OCSL S V "Fuenteovejuna" Its first printing was 1619, whlle Lope de Vega had written it between 1612 and 1614 This statement is curnous given the number of saints canonised since 1588 as well as the discernible Iberian presence amongst them

${ }^{262}$ Augustine, 114 "He [Ambrose] was reviving his body with the food that it needed or refreshed his mind with reading When he read, his eyes scanned the page and his heart explored the meaning, but his voice was silent and still we found him reading like this in silence, for he never read aloud." On the history of silent reading, see· Paul Saenger, Space between Words the Origins of Silent Reading (Stanford, CA· Stanford University Press, 1997), 1-17, 83-99, 120-30, 165-82, 256-78 
discourse. ${ }^{263}$ In reading Augustine's Confessions, the narrative both comforted Teresa of Ávila and facilitated the improvement of the self through comparison with a revered figure. ${ }^{264}$ Reading was a multifaceted practice that negotiated between individual piety and collective identification with Catholicism and its universal conception of sainthood.

Ribadeneyra and the Jesuits generally were voracious readers. They favoured catechisms, spiritual biographies, polemical literature, along with devotional and meditative literature. ${ }^{265}$ Specific works that appeared frequently in Jesuit correspondence and writings include: Augustine's Confessions, the Imitation of Christ, Denis the Carthusian's De quatuor novissimis, Luis de Granada's Tratado de la oracion, Cassian's Conferences, the works of Bernard of Clairvaux, and Ludolph of Saxony's Vita Christi. ${ }^{266}$ Jesuits as readers were neither unquestioningly reverent nor unceasingly critical, but changed according to circumstance. ${ }^{267}$ Edification also derived from handwritten media, whether through notebooks or the voluminous correspondence which passed through the Society. Following Ignatius's practice of keeping notebooks, members of the Society also maintained their thoughts and meditations in both separate sheets and

${ }^{263}$ Leturia, 2: 302-17.

${ }^{264}$ Teresa de Ávila, 89-90. "En este tiempo me dieron las Confesiones de San Agustín, que parece el Señor lo ordenó...Yo soy aficionada a San Agustín, porque...haber sido pecador, que en los santos que después de serlo el Señor tornó a Si hallaba yo mucho Consuelo, pareciéndome en ellos había de hallar ayuda y que como los había el Señor perdonado podía hacer a mí...como comencé a leer las Confesiones, paréceme me veía yo allí. Comencé a encomendarme mucho a este glorioso Santo. Cuando llegué a su conversión y leí cómo oyó aquella voz en el huerto no me parece sino que el Señor me la dio a mí según sintió a mi corazón." Cf. Teresa of Ávila, 69.

${ }^{265}$ Lazar, 291-92.

${ }^{266}$ Leturia, 2: 279-86. Other widely-read works were: Antoninus Suma historiale, the letters of Catherine of Siena, mystical treatises by a myriad of authors (Francis of Assisi, Catherine of Siena, Henry Suso, and Hendrik Herp), Vincent Ferrer's De vita spirituali, as well as the theological works by Gerson, Aquinas, and Bonaventure. These selections only partially correspond with the texts featured in the Regulae, 257-59.

${ }^{267}$ Haugen, 967-85. Through the example of the French Jesuit Jacques Sirmond and his lectures on Vergil, Haugen explores how a reader used sources, in this case an epic poem, as a verifiable historical source and its later manifestation in Sirmond's career as an ecclesiastical historian. 
notebooks. ${ }^{268}$ The encouragement of community through texts in the Society of Jesus became instıtutionalised during the generalshıp of Claudio Acquaviva ${ }^{269}$

Amongst these genres, saints' lives particularly Ribadeneyra's Flos sanctorum maintained their popularity. ${ }^{270}$ Saints' lives and the Imitation of Christ continued to be the books frequently read by Jesuits ${ }^{271}$ In the Sptritual Exercises, Ignatius directed retreatants to ponder the lives of saints while eatıng since it dimınishes the sensual enjoyment of the food ${ }^{272}$ The Jesuit Constıtutions argued that books such as saints' lives should be read during mealtimes as they provide nourishment for the soul. ${ }^{273}$ The Ratıo studiorum, an outline of the Society's educational program, instructed professors to enthusiastically suggest spiritual reading most especially the lives of saints ${ }^{274}$ The most notable example in the Society, however, was Ignatius's reading of a redaction of saints' lives. This episode appeared in his Autobıography and Ribadeneyra later included it in his

${ }^{268}$ On notebooks, consult Ignatıus, "Acta Patris Ignatı," [11], Paul Nelles, "Libros de papel, libr blanchl, libri papyracel Note-takıng Techniques and the Role of Student Notebooks in the Early Jesuit Colleges," Archivum Historicum Socletatts lesu 76 (2007) 79-85, 95-102, idem, "Seeng and Writıng," 318-26. On letters, consult Friedrich, 14-29, Palomo, "Corregir letras," 60-74

${ }^{269}$ Leturia, 2 317-31

${ }^{270}$ Lazar, 305-7, Leturia, 2 273-83 Cf Leturia, 2279 "Pero hemos advertido que la recomendacion ıgnaciana no favorece a ningun autor determınado Es que escribe para todos los tiempos, y el Flos sanctorum del suyo, al que su alma tanto debia, mezclaba los grandes aciertos con defectos no menos grandes contra la critıca y el buen gusto Es interesante advertır que los catalogos de lecturas recomendables para uso de la Compañía de que haremos recuento mas adelante, recogen cuidadosamente las nuevas vidas de santos de Lipomano y de Surı que van en el siglo XVI reformando el viejo Flos sanctorum Desde el fin del siglo, son ya autores jestuias los que sacan las consecuencias del espiritu de los ejercitos editando sus propias collectiones hagiograficas en 1595 el P GP. Maffe1, en 1599 el P Pedro de Rıbadenerra, en 1607 el P Erıberto Rosweyde Es sabıdo que este ultımo prepara el camıno a la monumental coleccion de los Bolandos"

${ }^{271}$ Regulae, 257-58

272 Ignatıus, Exercitta Spirtualia, [215] "Otra vez, mientras come, puede tomar otra consideración, o de vida de sanctos, o de alguna pía contemplación, o de algún negocio spırıtual que aya de hazer, porque estando en la tal cosa attento, tomará menos delectación y sentımiento en el majar corporal "

${ }^{273}$ Ignatius, Constitutiones, III, 1, [85] "precediendo la bendición y siguiéndose la action de gracias, que todos deuen dar con la deuovión y reverencia convenıente, y entre tanto que se come, dándose alguna refection assímesmo al anıma, con leers algún libro pío más que difficil que todos puedan entender, y dél aprouecharse, o con predicar alguno en el tal tiempo"

274 "Ratto," 417 "Lectionem spiritualem, praesertım de sanctorum vitıs, vehementer commendet, contra vero non solum upse ab impuris scriptoribus, et omnıno in quibus sit alıquid, quod bonıs moribus nocere queat, ıuventutı praelegendıs abstıneat, sed ab ıısdem etıam extra scholam legendıs discıpulos, quam maxime potest, deterreat" 
life of Ignatius. ${ }^{275}$ Ribadeneyra described how Ignatius read the life of Christ and a Flos sanctorum, an incremental process that awakened Ignatius's piety:

It was at this very curious time when, accustomed to reading books of chivalry, and in order to pass the time in bed which his illness made long and annoying, Ignatius asked that they bring him some such vain book. God willed that they had no books in the house other than those of spiritual things, which were offered to him; which he accepted, more for entertainment than by inclination or devotion. They brought him two books, one on the life of Christ our Lord, and the other on the lives of saints, commonly called the Flos sanctorum. He began to read them, at first (as I said) to pass the time, then gradually out of love and pleasure. [...] Not only did he begin to enjoy them and to desire to imitate and to do what he had read, but they also changed his heart. ${ }^{276}$

Reading the lives of Christ and the saints thus sparked Ignatius's conversion. However, he had to first internalise the accounts and then imitate the conduct featured therein within his life.

The interaction between reading and the replication of saintly conduct reappeared in Rodríguez's Practice of Christian Perfection. Rodríguez was a contemporary of Ribadeneyra, both were early recruits into the Society. The Society was an institution built on multimedia; in it, reading and hearing texts promoted orthopraxy through following the example of saints and an orthodox Catholic community. Thus, Rodríguez recalling his lengthy career as a spiritual advisor and as a master of noices counseled his readers that

All the saints greatly recommend this spiritual reading. And the experience shows us well, how advantageous it is, since we have histories full of great

${ }^{275}$ Ignatius, "Acta Patris Ignatii," [5-7].

${ }^{276}$ Ribadeneyra, Vita Ignatı, [87] "Era en este tiempo muy curioso, y amıgo de leer libros de cavallerías, y para pasar el tıempo con la cama y enfermedad se le hazía largo y enfadoso, pidió que le truxessen algún libro desta vanidad Quiso Dios que no huviesse ninguno en casa, sıno otros de cosas espirituales que le ofrecieron; los quales él acetó, más por entretenerse en ellos que no por gusto y devoción. T[r]uxéronle dos libros, uno de la vida de Christo nuestro Señor y otro de vidas de Santos, que comúnmente llaman Flos sanctorum. Començó a leer en ellos, al prıncipı (como dixe) por su pasatıempo, después poco a poco por afición y gusto ..Y no solamente començó a gustar, mas también a trocársele el coraçón, y a querer imitar y obrar lo que leia." 
conversions to the Lord acted upon this path. This reading is such a pivotal and important medium for our advancement that the founders of religious orders came to order their religious to read spiritual things each day. These founders based this reading on the doctrine of the Apostle and the authority and experience of the saints...In the Company, we have a rule for spuritual reading, that says: Twice datly the brothers must set aside time to examine their conscience, and to prayer, meditation, and reading, with all diligence in the Lord. ${ }^{277}$

For Rodríguez, religious reading was the gateway towards the spiritual life. It allowed the reader to percerve the virtue of saints separated by time and space, devotional literature lessened the discrepencies between present and past to provide a universal code of sanctity. In turn, saints' lives also provided examples of piety imitated by readers, an example of the appropriation of sanctity through texts When considering the reading of Flos sanctorum, there was a contrast between the subjective acquisition of saintly virtue and its need for regulation. Saints' lives were empty texts until their readers assigned them divinity through language laden with religious identity. ${ }^{278}$ Rodríguez then placed the practice of reading saints' lives within the daily routine of Jesuit spiritual life and correlated reading with meditation, prayer, and self-reflection.

Rodríguez's discussion incorporated the senses into the acquisition of saintly exemplars through reading. He also included the types of reading found in Augustine's Confessions. Rodríguez advises his readers that

${ }^{277}$ Alonso Rodríguez, Exercicio de perfectón y virtudes cristianas, 3 vols (Seville Matras Cavijo, 1609-1616), 1:381-82 "Todos los santos encomiendan mucho esta leccion espiritual I la experiencia nos muestra bien, de cuanto provecho sea, pues tenemos llenas las historias de conversiones grandes, que a el Señor obrado por este camıno. I assi, por ser esta leccion un medio tan principal, 1 tan importante para nuestro aprovechamiento, los instituidores de las religiones, fundados en la doctrina del Apostol, 1 en la autoridad, 1 experiencia de los santos, vinieron a ordenar, que sus religiosos tuviessen cada dia leccion espirtual. .En la Conpañia, tenemos regla desta leccion espiritual, que dize * Todos cada dia dos vezes de el tiempo, que les fuere señalado, al examen de su conciencia, 1 a la oracion, meditacion, 1 leccion, con toda dilige[n]cia en el Señor *" When translatıng, I also consulted: Idem, Practtce of Christtan Perfection and Christzan Virtues, 3 vols, trans Joseph Rickaby (Chicago Loyola University Press, 1929) For more on Rodriguez, see DHSJ, J P Donnelly, "Rodríguez, Alonso (II)," 4 3394-95

${ }^{278}$ Certeau, Writing of History, 259-65; Chartier, Order of Books, 30-36 
It helps to often read and hear the lives and the examples of the saints, as well as consider their excellent and heroic virtues. The church suggests their virtues to us, to awaken us out of our tepidness so that we avord traveling as far as them. And this reading provides another advantage, if you want them with you when confused and humbled, considering the purity of life of the saints and seeing how far we are from achieving what they have ${ }^{279}$

In Rodríguez's discussion of two approaches to reading, he depicted the means for the fatthful to obtain orthodox models of behaviour as well as its association w1th Catholic community. Reading and hearıng the lives of saints facllitated the opportunity for the faithful to appropriate the virtues of the saints they had heard about and they were mindful of saints' failings. ${ }^{280}$ At the same time, the re-enactment of the qualities of saintly exemplars instituted a universalised code of conduct of an early modern confession that readers followed ${ }^{281}$

Similar approaches to the practice of reading featured in the writings of another Jesuit contemporary of Ribadeneyra, Francisco Arıas. In the prologue to the reader in his Book on the Imitation of Christ, Arias established that his book provided instances of Catholic virtue through Christ's life, which the example of the saints reinforced. ${ }^{282}$ This

${ }^{279}$ Rodríguez, $143-44$ "Para esto ayuda a ta[m]bien mucho leer, 1 oir las vidas, 1 exe[m]plos de los santos, 1 considerar sus virtudes excelentes, 1 heroicas 1 para esso nos las propone la 1 glesia, para que ya que no lleguemos a tanto, como ellos, a lo menos, nos anımenos, a salır de nuestra tibieza I trae esto otro provecho consigo quandaremos si quiera confundidos, 1 humıllados, considerando la pureza de vida de los santos, 1 viendo cuan lexos estamos nosotros de llegar a lo que ellos llegaron"

${ }_{280}$ Rodríguez, 1390 "S[an] Gregorio tratando desto, dize q[ue] la sagrada Escritura, 1 lo mismo podemos entender, de cualquiera otra leccion espiritual, es como ponernos un espejo dela[n]te de los ojos del alma, para q[ue] en el veamos nuestro interior Porque aí conocemos, 1 echamos de ver lo bueno, 1 lo malo q[ue] tenemos I cua[n]to aporvechamos, o cua[n] lexos vamos de la perfeccion $I$ cue[n]tan senos all algunas vezes los hechos admirables de los santos, para anımarnos a imitarlos, 1 para q[ue] viendo sus gra[n]des victorias, 1 triu[m]fos, no desmayemos en las tentaciones I trabajos"

${ }^{281}$ Palomo, "Corregir letras," 75-77, idem, "Disciplina cristıana," 127-36

${ }^{282}$ Francisco Arias, Libro de la imitacion de Christo nuestro Señor (Seville Clemente Hidalgo, 1599), title page, sig A fol 1 "en el qual se recogen los bienes que tenemos en Christo nuestro Señor, y se comunican a los que lo imitan. Y se proponen las virtudes del mismo Señor, en que los devemos imitar, sacadas del Evangelıo, y confirmadas con autoridades y exe[m]plos de santos Y saber, considerar bien los medıos, con que estos bienes se alcançan de Dios, y se comunican por Dios a las almas Pues esto es, lo que pretendemos en este libro Lo primero hazer vna summa y compendio conforme a nuestra capacidad de todos estos bienes espirituales, que tenemos en Christo, y que se nos dan por su virtud y merecimiento $\mathrm{Y}$ tambien explicar la naturaleza y calıudad de cada vna de las virtudes Theologales y Morales, y de las 
text was intended to assist mental prayer, which encouraged the reader towards virtue through imagining the life of Christ:

And this book will also treat of spuritual progress, and in it we urge the imitation of the virtues of Christ, and we teach how mental prayer ought to be practiced, to remove living and effectives desires from this imitation. And in it we urge the exercise of mortification, which removes vices and passions from the heart, which prevent the perfect imitation of Christ. All of which was like a disposition, to come in particular to treat the examples and deeds of Christ, and of the virtues of his holiest life and passion, which we have to follow and imitate: and of all the good things that we have in it, and which are communicated to us by means of this blessed imitation. ${ }^{283}$

In conjunction with mental prayer, Arias considered his book a complementary tool to assist in ministries through reading aloud from the work in sermon or any other preaching. ${ }^{284}$ The imitation of holy exemplars practiced in early modern Catholicism was

operaciones y actos dellas. y para cada bra y exercicio de virtud traer todos, o los principales exemplos, que Christo en su vida y passion nos dıo de aquella virtud, y peracion virtuosa, que estan escritos en la historia Evangelica $Y$ no solamente los exemplos de Christo, que en comun mueven a las virtudes, y que estan tan claros y patentes en su vida, que luego se ofrecen a la consideracion de cada vno sino tambien los exemplos, que muy en partıcular enseñan, y persuaden las virtudes y actos dellas, y los que no se descubren luego a todos, sino que los santos Doctores en la exposicion de la historia Evangelica, y en los libros que an compuesto de varias materias espirituales, los an notado, y advertıdo con la copıosa y singularıssima luz, que Dios les á dado para entender la Escritura sagrada, y sufrir, y ponderar las virtudes, que Christo en quanto hombre exercitó en el mundo, y los exemplos que dellas escrivieron los sagrados evangelıstas $\mathrm{Y}$ aunque es verdad, que de esta materia, que es de los bienes que tenemos en Christo, y de los exemplos, que nos dio para cada virtud, an tratado todos los santos y todos los varones sabıos, que an escrito libros espirituales tocando y explicando desta materia, vnos vnos puntos, y otros notando, y declarando otros a proposito, de lo que yvan trata[n]do en sus libros' mas recoger todos estos bienes en particular, y ponellos delante de los ojos, para poder sin largo estudio, y sin muchos trabajo, sino con brevedad y facilidad sabellos y co[n]siderallos, y aplicar todos los exemplos de Chrısto, q[ue] estan en el eva[n]gelıo, a cada virtud, y peracion virtuosa, para q[ue] el que dessea aquella virtud, y procura alcançalla, vea juntos todos los hechos, con q[ue] Christo la enseña, y persuade"

${ }^{283}$ Ibid sig A 2r "Y viene tambien este libro a proposito del que compusimos del aprovechamiento espiritual, porque en el exhortamos a la imıtacion de las virtudes de Christo, y enseñamos como la oracion mental se á de ordenar, a sacar desseos vivos y eficaces desta imitacion $\mathrm{Y}$ en el exhortamos al exercicio de la mortificacion, con el qual se quitan del coraçon los vicios y passiones, que impiden la perfecta imitacion de Christo. todo lo qual fue como vna disposicion, para venır en particular a tratar de los exemplos y hechos de Christo, y de las virtudes de su santissima vida y passion, que devemos seguir y imitar y de los summos bienes que en el tenemos, y se nos comunican por medio de esta santa imitacion."

${ }^{284}$ Ibid sig. A fol 3 "Servira tambien, para que los varones de Dios que se dan al exercicio santo de la oracion me[n]tal y meditacion y contemplacion de las cosas divinas, te[n]gan delante de los ojos materia copıosissima, que meditar .Fuera desto, a muchos minıstros de la palabra de Dios podra ser alguna ayuda, para que quando en sermones y platicas quiera[n] declarar los mysterios de Christo, que es la materıa ordınarıa, de que se deve tratar en los sermones, tengan mas a la mano la inteligencia de los tales 
facilitated by reading books both silently and aloud In turn, the consumption of texts promoted an idea of community based on doctrinally-correct conduct Reader prologues, which featured extensively in Jesuit writings, were ideal sites for exploring religious reading

\section{$\underline{\text { Reading Ribadeneyra and the Flos sanctorum }}$}

The reader prologues of Ribadeneyra's writıngs corroborated the relationship between reading, appropriation of behaviour, and confessional identity In his life of Ignatius, Ribadeneyra noted that the actions and endeavours of the Society's founder will be heard as well as read, and then known by Jesuits and non-Jesuits alıke ${ }^{285}$ Ribadeneyra correlated an epistemology of exemplars through reading and hearing sants' lives Through the interaction with this text, the memory created an image of Ignatius's life through which his virtues become accessible to the reader, who will then imitate them ${ }^{286}$ For Ribadeneyra, the reader used this sacred biography as a memory aid so that they could recreate in their minds an exemplary Catholic life At the same time, Ribadeneyra absolved himself from any fault in this process of recollection, which echoed the Spiritual Exercises ${ }^{287}$

mysterios, sacada de la divina Escritura, y de la Theologia escholastica, y de la doctrina de los santos, y juntamente la aplicacion dellos a las costumbres, y vida Christıana"

${ }^{285}$ Ribadeneyra, Vita Ignatıl, 64 "Ay tambien otra razon que haze mas ligero este mı trabajo, y es el desseo grande que entıendo tienen muchos de los de fuera y todos vosotros, hermanos mios muy amados, teneis mas crecido, de oyr, leer y saber estas cosas"

${ }^{286}$ Ibıd 67 "Otra ay, que es mas domestica y propıa nuestra, que es de seguir e imıtar a aquel que tenemos por capitan Porque debemos tomarle por espejo de nuestra vida, y procurar con todas nuestras fuerzas de seguirle, de suerte, que, si por nuestra imperfeccion no pudieramos sacar tan al vivo y tan al propio el retrato de sus muchas y excelentes virtudes, a lo menos imitemos la sombra y rastro dellas $\mathrm{Y}$ por ventura para esto os sera $\mathrm{m} 1$ trabajo provechoso y tambien gustoso y agradable, pues el deseo de imitar haze que de contento el oyr contar lo que imitar se desea, y que sea tan gustoso el saberlo, como es el obrarlo provechoso"

${ }^{287}$ Ibid "Procurare, pues, renovar la memoria de su vida tan exemplar, que ya parece que se va olvidando, y de escribirla, si no como ella merece, a los menos de tal manera que ni el olvido la sepulte, ni el descuydo la escurezca, nı se pierda por falta de escritor" See also Nelles, "Seeıng and Writıng," 320-23 
Ribadeneyra's life of Ignatius was a pivotal text for Jesuit spırituality It provided a memorial to the Society's earliest saint, positioned as part of Ribadeneyra's conception of a community of authentic and Catholic believers united against all heresy These histories provided confessionally-appropriate conduct but also facilitated an emotional engagement with the reader, who will then be inspired to imitate the vurtues he or she remembered. ${ }^{288}$ This process of virtue-aquisition was gradual. As the reader recalled more exemplars, they undertook a pilgrimage by travelling "on the road to Christian perfection", which is an imitation of Christ. ${ }^{289}$ Ribadeneyra's religious community turned towards the early church, one based on "the principles of the primitıve Church" and built on "the patience and strength of the saintly martyrs." 290 Ribadeneyra's conception of Catholics as martyrs encompassed his Jesult brethren including the members of the Society put to death during Elizabeth I's reign. ${ }^{291}$

Reader prologues and dedications were suggestive of the work's readers as well as Jesuit patronage networks. ${ }^{292}$ Ribadeneyra's prologues called "to the Christian and

${ }^{288}$ Ibıd 736 "Escriviendo la vida de nuestro B P Ignacio y contınuándola hasta su dichoso tránsito, de industria he dexado algunos partıculares exemplos de sus virtudes, que me pareció que, leydos a parte de la historia se considerarían mas atentamente y se arraigarıan mas en la memoria y moverían mas el afecto de los que los leyessen, col el desseo de imitarlos"

${ }^{289}$ Ibid "Y por esta causa, en este quinto y ultımo libro ire recogiendo y entresacando algunas Flos de singulares virtudes que en el vimos y conocimos muchos de los que oy somos vivos No quiero dar la razón porque cuento algunas cosas menudas, pues escrivo a mis hermanos y relıgıosos de la Compañía de Jesús, que nınguna cosa del padre a quien dessean imitar les parecerá pequeña Especialmente, que no se debe tener en poco lo poco, si con ello se alcanca lo mucho, y en el camino de la perfección quien menosprecia lo baxo cerca está de aver de lo alto, y por el contrarı, Christo nuestro Señor no ensena que el que es fiel en lo que es poco, también lo será en lo que es mucho"

${ }^{290}$ Ribadeneyra, Histona ecclesiastıca, sig $\uparrow 5 \mathrm{v}$ "la paciencia y fortaleza de los santos martyres y finalmente el estrago, confusion y assolamiento de vn Reyno noble, Catolico, poderoso, y que con grande lo a luego a los principios de la primitiua Yglesia tomo la fe"

${ }^{291}$ Ibid sig $+8 \mathrm{v}$ "Entre estos que han muerto por Fe en tiempo de Isabel, los principales han sido algunos Padres de nuestra Compaña, Ingleses de nacion los quales quisıeron ser antes apuros tormentos descoyuntados y muertos, que apartarse vn pelo de la confession de la verdad Catolica "

292 Baldwin, 297-303 
benign Reader" and "to the pious Reader". ${ }^{293}$ His patrons, meanwhlle, were members of the Spanish royalty or nobility. ${ }^{294}$ The patrons of the Flos sanctorum were Margaret of Austria (the 1599, 1601, and 1604 editions), the Infanta Margaret (the 1604 edition with the extravagantes), and the Duchess of Feria, Jane Dormer (the 1609 edition). Even works without any obvious patrons signified a similar relationship between the writer and the printer, since the latter agreed to produce books likely to have a profit. For instance, the Plantin house of Antwerp would not have printed two editions of Ribadeneyra's catalogue of Jesuit writings if there was not a market for it. $^{295}$ The same applied for Ribadeneyra's Vita Ignatı that also lacked a patron, but nonetheless had thirteen editions throughout Europe. ${ }^{296}$ Villegas did not always have dedications to nobles, but had extensıve printings. In the 1588 edition, Villegas dedicated the Flos sanctorum to Philip II, while the 1609 edition lacked a dedication. For Villegas, reading saints' lives was akin to the creation of a cognitıve image representing the good and evil withın confessional discourse. ${ }^{297}$ While secular and official histories in early modern Spain were either for the fatherland or for a person, a simular division existed in the Flos sanctorum by Villegas

${ }^{293}$ Ribadeneyra, Flos (1599), sig q9 1r, 801. "Al Christıano y benigno Lector", "Al pradoso Letor" In his other works, Rubadeneyra maintains the same language, here are some examples: idem, Historia ecclesiastica, sig $\uparrow 5 \mathrm{r}$, "El Avtor al Christiano y piadoso Lector", idem, Tratado de la Religion, sig. $\dagger \uparrow 3 r$, "Al Christiano y piadoso Lector" In the preface to his life of Ignatius, Ribadeneyra describes a Jesult community: ıdem, Vita Ignatı, 64, "A los hermanos en Christo caríssimos de la Compañía de Jesus"

${ }^{294}$ Ribadeneyra's patrons are usually indicated on the title-pages of his writings Examples include Prince Philıp (later Philıp III) for the Histona ecclésıastica and his ant1-Machiavellian treatıse Tratado del principe cristiano as well as Maria of Austria for his Tratado de Tribulacion.

${ }^{295}$ Pedro de Ribadeneyra, Illustrium scriptorum religionis Societatis Iesu catalogus (Antwerp: Plantın, 1608); tdem, Catalogus scriptorum religionis Socletatts Iesu (Antwerp Plantın, 1613)

${ }^{296}$ In the period between the first Latın printing in 1572 and his death in 1611, there were six Latin editions and seven Castilian editions and it was printed in Venice, Madrid, Lyon, Ingolstadt, and Antwerp The Gómez (Alonso then his widow) printıng house of Madrid between 1583 and 1586 produced four editions including one Latin and Castilian edition each in 1586.

${ }^{297}$ Villegas, Flos (1588), sig \ 1r. "Y como biua image[n] representa a los presentes las vidas de los passados, y sus hechos buenos y malos, hazıe[n]do á todos ciertos, de que si obraren bien, eternizara sus nombres, y los porna en la lista y catalogo de los famosos y sı mal, que no por esso se oluidara dellos, sino q[ue] publicara sus malas obras, para que sean conocidos de todos los presentes y por venır, y tenidos en lo que por ellas merecieren Y si la historia en comun trae al mundo tan importante prouecho, quanto mayor, y mas importante le traera la hıstoria partıcular de vidas de santos." 
and Ribadeneyra. ${ }^{298}$ Villegas's sacred biographies corresponded to distinct categories according to religious practıce and nationality including a dedicated section on Spanish saints. Ribadeneyra, meanwhile, did not group the lives in the same way. His Flos sanctorum included saints in the Breviary, the extravagantes, as well as the lives of exemplary Jesuits. Villegas continued the practice of writing histories for the fatherland, while Ribadeneyra focused more on creating confessional narratives and his order's integration into Catholicism Ribadeneyra's work was a sacred history and an ecclesiastic history since Ribadeneyra used saints as an exploration of devotion as well. ${ }^{299}$

Ribadeneyra, meanwhile, equated sacred letters with devotional works, as reading the lives of saints enabled the acquisition of a repository of conduct consistent with confessional discourse. Moreover, this practice also distinguished believers from heretics based on the practice of reading and on adherence to norms of behaviour for Catholics. ${ }^{300}$ These saints' lives contributed to the social disciplining of Catholics and asserted the centrality of the Roman Church. The belief in Rome as the centre of the apostolic and universal church was part of a distnnctly Catholic ideology. Yet many Catholics felt little if any attachment to Rome, behaving instead as Catholics according to civic, regional, and religious regulations imposed upon their community. The Roman Church as the "head and master of the others" was the fount of institutional imitation; all other

${ }^{298}$ Richard L. Kagan, Clio and the Crown The Politics of History in Late Medieval and Early Modern Spain (Baltımore: Johns Hopkıns Unıversity Press, 2009), 14.

${ }^{299}$ Ditchfield, "Thinking with the Saints," 571-73. Hagiography is one instance of sacred history, which can be simultaneously universal and local. In Ribadeneyra's case, the Flos sanctorum depicts Jesuit as well as Catholic devotions. An excellent case study that investigates the negotiation of Catholic, religious order, and regional identities through the copatronage controversy involving James the Greater and Teresa of Ávila, see Rowe.

${ }^{300}$ Ribadeneyra, Flos (1599), sig. Tा fol 2 "Demas desto, es vn fuerte escudo, y defensa contra los infieles q[ue] la contrastan, y vn martillo y cuchillo contra los hereges, cuyos errores y desatınos con nunguna cosa se co[n]uencen mejor, $\mathrm{q}[\mathrm{ue}]$ con los exemplos de los Santos Porq[ue] es mas excele[n]te modo de enseñar con obras, q[ue] con palabras y las obras de los Santos son santas, y contranas en todo y por todo á los disparates y desuarıos de los hereges. $\mathrm{Y}$ assı para conuencerlos, é interpretar las cosas dudosas, y lugares dificıles de las diunas letras, es gran luz la vida y exe[m]plos de los Santos" 
Churches whether in Smyrna, Leon, Vienna, or France were subservient to Rome ${ }^{301}$ Ribadeneyra's mention of Smyrna revealed a certain millennalism through alluding to the Book of Revelation's discussion of the Seven Churches and the Second Coming. The Church of Smyrna was the community that would suffer persecution. ${ }^{302}$ Ribadeneyra did not elaborate on the status or the role that the other Churches would play in this religious transformation. Instead, all Catholic eyes should look to Rome for spiritual leadership.

Elsewhere, Ribadeneyra contrasted the reading of hagiographies with biographies of emperors or non-Christian philosophers. In the consumption of worldly texts, the reader remained anaemic, whereas to ingest a saint's life through reading nourishes the soul:

Or again, we mixed in straw with the grain, and our speeches with wonderful examples of the saints, and we would deliver a long sermon to the people full of delicate concepts, but very far from the life of the Saint that we were discussing. And if the Lord with the flame and the fire of his spirit, does not illuminate and inflame the heart, nor guide the pen of the writer, all his words would be dry and cold, and after reading them, the Reader is left so dry and cold, and so out of substance and fruit, as if he had not read the life of a saint, but of an Emperor, or a pagan phlosopher, and not achieved the main aim that one ought to have in writing the lives of the Saints. ${ }^{303}$

${ }^{301} \mathrm{Ib} 1 \mathrm{~d}$. sig 9 9 $2 \mathrm{v}$ "Pues para nosotros que son las vidas de los Santos, sino vn dechado, y vn espejo, que deuemos tener siempre delante de nuestros ojos, para mirar en el nuestras fealdades y vicios, y emendarlos, y las heroycas virtudes dellos, para despertar nuestra tıbieza, é imitarlos? Por todos estos respetos la santa Yglesia celebra las memorias de los Santos con tanto cuydado y piedad Pero no solame[n]te la Yglesıa Romana, q[ue] es la cabeça y maestra de las demas, tuuo este cuydado, sino ta[m]bie[n] otras la imitaro[n], como la de Esmirna, y las de Leo[n] y Viena de Fra[n]cia"

${ }^{302}$ Revelation 2 8-11. The Society had founded a residence in Smyrna by 1623, part of the order's mission in Greece, please see DHSJ s v C Capızzı, "Grecia," 2 1809-11.

${ }^{303}$ Ribadeneyra, Flos (1599), sig. ๆๆ 3v "Otras, que mezclamos en ellas nuestra paja con el grano, y con los exemplos maraullosos de los $\mathrm{Sa}$ [n]tos nuestros discursos' y aunque propongamos al pueblo vn largo sermon, lleno de delicados conceptos, pero muy agenos de la vida del Santo que tratamos. Y s1 el Señor con la lumbre y fuego de su cspırıtu, no alumbra é inflama el coraçon, y rıge la pluma del escritor, todas sus palabras son secas y frias y despues de auerlas leydo, queda tan seco y frio el Lector, y tan sin xugo y fruto, como si no huviera leydo la vida de vn Santo, sino la de vn Emperador, ó de vn Filosofo Gentıl: y no se consigue el fin principal que se deue tener en escreurr las vidas de los Santos "Rıbadenerya had earlıer described the dangers of writıng saints' lives haphazardly as a detriment to the reader who wishes to learn more about Catholic virtue. This passage is one of the many contrasts Ribadeneyra was makıng For hım, the hagıographer must be dilıgent and studious 
The act of reading provided the soul consolation, asserted a religious identity, and enabled the communication of proper conduct. The practice itself was imitative and initiated spiritual transformations. Rıbadeneyra recalled Ignatius's conversion through reading a Flos sanctorum and then placed it among other transformations facilitated by books. One example was the account of the Roman noblemen and noblewomen who forfeited their worldly existence to become Christian martyrs after reading Athanasius's Life of Antony. Another was Giovanni Colombini's transformation from a Sienese gentleman into a founder of the Jesuati and its monasteries after reading a life of Mary of Egypt. ${ }^{304}$ Ribadeneyra wished to show the transformative power of hagiography, the ability of sacred biography to trigger a volte-face towards piety and living an orthodox life.

The discrepancies between readers manifested in their printed marginalia The use of marginalia was common enough for Cervantes to lampoon it in the prologue of Don

${ }^{304}$ Ibid sig 9 fा fol. 4 "Pero no ha sido el menor motıuo para lleuar adela[n]te esta empresa, el acordarme q[ue] nuestro bienaue[n]turado Padre Ignacio, Padre y fundador de n[uest]ra mınma $\mathrm{Co}[\mathrm{m}]$ paña de Iesus (á cuyos pechos, por partıcular miserıcordıa del Señor, yo me crie) siendo soldado, y sumıdo en la vanıdad del mundo, abrió los ojos del alma, y se conurtıo á Dıos, por leer las vidas de los Santos; aunque al principio las leya mas por entretenımıento, que por deuocion $\mathrm{Y}$ el saber, que el leer la vida de S[an] Antonıo Abad, escrita por S[an] Atanasıo, fue causa que en Roma muchos caualleros, y señoras nobrlissımas, diessen de mano á todo regalo de la carne, y pompas del siglo, y tomando habıto relıgıoso, se crucificassen con Chrısto, como lo escriue S[an] Geronımo, alabando á santa Marcela biuda, por auer sido la prımera que con su exemplo mouı á las demas Y que S[an] Iuan Columbıno, cauallero Senes, por leer la vida de santa Maria Egypciaca, se entrego con ta[n] grande feruor al seruicio del Señor, q[ue] vino á fundar la relıgion de los que Ilaman Iesuates, en Italıa, donde florece, y tiene muchos monesterios El saber esto ha sido grande estımulo para mı floxedad, y alıuıo para mi poca salud porque espero que alguna alma descaminada, leyendo lo que yo escrulere, y tocada co[n] la mano del Señor, entrará en cammo, y le tomará por su guia, y por su luz y alomenos que será prouechoso para mı, el obedecer á la voz de Dios, y tomar este trabajo por solo zelo de su gloria, y ho[n]ra de los Santos, ornamento de la Yglesia Catolica, vtılıdad de los fieles, y confusion de los hereges y para edificar mi alma con leer y escriuır vidas tan preciosas y admirables y que si viniere la muerte me tomará en buena ocupacion, y los mismos Santos me alcançara[n] perdon de mis pecados, por este pequeño seruıcıo que yo les pretendo hazer. Y assı debaxo de la sombra y proteccion dellos, y confiado en la dıuına mıserıcordıa, é ınuocando el espiritu y fauor del Señor, te[n]damos las velas, y entremos en esta nauegacion, con esperança de llegar al puerto desseado" 
Quixote. ${ }^{305}$ Sixteenth and seventeenth-century readers distrusted books. ${ }^{306}$ The ambivalence towards books perhaps encouraged printers to include notes printed in the text's margins. ${ }^{307}$ While Pedro de la Vega's Flos lacked any marginalia, Villegas and Ribadeneyra's redactions included printed text in the margins. Villegas had some citations, while Ribadeneyra revealed a tendency towards exhaustive research, which recalls the anecdote about how he chased down Baronius's footnotes. Marginalia had different purposes, but in the compilations they were annotations and summaries. For Villegas and Ribadeneyra, marginal annotations served as textual authorities through providing references to Scripture as well as classical or historical works. Summaries, meanwhile, abridged and contextualised the text's narratives to assist the book's reader. ${ }^{308}$ While Villegas's marginalia was annotative and summarising, Ribadeneyra's were strictly annotative. These notes in the margins provide a list of sources authenticating Ribadeneyra's Flos sanctorum. Simultaneously negotiating religious tradition as well as the humanist call to return to the sources, Ribadeneyra places his redaction of saints' lives within the corpus of sacred history from its apostolic origins through his citations. ${ }^{309}$ The engagement with history was not new to Ribadeneyra, since the completition of the Jesuit spiritual exercises required it. The director leading the exercises had to maintain a journal of the exercitant's contemplation, a journal that provided a basis for further enlightenment by ample contextualisation of the exercitant's

${ }^{305}$ Cervantes, Quyote, 13-15. Cf. Don Quixote, 14-16.

${ }^{306}$ Adrian Johns, The Nature of the Book Print and Knowledge in the Making (Chicago: University of Chicago Press, 1998), 1-57.

${ }^{307}$ Willaam H. Sherman, Used Books Marking Readers in Renatssance England (Phıladelphu: University of Pennsylvanıa Press, 2008), 5-15.

${ }^{308}$ William W.E. Slights, Managing Readers Printed Marginalia in English Renatssance Books (Ann Arbor, MI: Unıversity of Michıgan Press, 2001), 19-60, especially 25-26; Carmen Peraita, "Marginalizing Quevedo: Reading Notes and the Humanistic Persona," in Reading Notes, eds. Dirk Van Hulle and Wim Van Mierlo (Amsterdam and New York: Rodopı, 2004), 37-60.

${ }^{309}$ Sherman, 73-76. 
thoughts and sins. ${ }^{310}$ Marginalia portrayed what an author had read, a practice consistent with ecclesiastical writers and therr use of marginalia and citations, such as the Jesuit Athanasius Kirscher and the Oratorıan Baronius ${ }^{311}$ Ribadeneyra's citations provided proof of his efforts to integrate his compilation of saints' lives into the history of Catholıcism and Christianity after Protestant criticısms about sources This process is similar to Ribadeneyra's inclusion of exemplary Jesuits amongst official saints and extravagantes

\section{Ribadeneyra as Reader}

Ribadeneyra, as a Catholic reader, followed the lists of works to read and to avoid according to the protocols of confessional discourse The church encouraged the production of numerous editions of the infamous Index librorum prohıbitorum to inform Catholics about heretical texts. Louvain issued the first index in the 1540 s, followed by subsequent editions from Italy and Spain throughout the early modern period. ${ }^{312}$ Instead of listing heretical texts, members of the Society produced indexes of works meant to be read. One example is the Btbliotheca selecta of Antonio Possevino, first printed in Rome in 1593, a compendium of Catholic orthodoxy found in books ${ }^{313}$ A bibliographical

${ }^{310}$ Ignatıus, Exercitıa Spirttualıa, [2] "La segunda es, que la persona que da a otro modo y orden para meditar o comtemplar, deue narrar fielmente la historia de la tal comtemplatión o meditación, discurriendo solamente por los punctos con breue o sumaria declaración, porque la persona que contempla, tomando el fundamento verdadero de la historia, discurriendo y raciocinando por sí mismo, y hallando alguna cosa que haga un poco más declarar o sentır la historıa, quier por la racioncınacion propıa, quier sea en quanto el entendımıento es illucidado por la virtud dıuına, es de más gusto y fructo spirıtual, que si el que da los exercicios hubiese mucho declarado y ampliado el sentido de la historia, porque no el mucho saber harta y satısfaze al ánıma, mas el sentır y gustar de las cosas internamente"

${ }^{311}$ Anthony Grafton, The Footnote A Cunous History (Cambridge, MA Harvard University Press, 1997), 148-76 A good summary of Baronius's contributions to historiography is Cyriac K Pullapilly, Caesar Baronius Counter-Reformation Historian (Notre Dame, IN, and London Notre Dame Unıversity Press, 1975), 144-77

${ }_{312}$ Two of the better overviews of Inquisitional control of books can be found in Pardo Tomás, 21-45, 49-66, Pinto Crespo, 97-124, 137-46

${ }^{313}$ DHSJ s v M Scaduto, "Possevino, Antonıo," 4 3201-3, Antonio Possevino, Bibliotheca selecta (Rome Typographica Apostolıca Vatıcana, 1593) 
enterprise that encouraged Catholics to engage with books, it followed the Society's Ratio studiorum and provided a comprehensive catalogue on the liberal arts, medicine, law, philosophy, and theology. Possevino envisioned bibliography as a means to decipher and reveal the history of Catholicism through books, to which he included his Jesuits brothers. The desire to compile texts into inventories was a discernible practice in sixteenth and seventeenth-century Europe. The practice was not the exclusive domain of religion, such as Conrad Gesner's Bibliotheca universalis that sought to compile every Latin, Greek, and Hebrew book printed since the fifteenth century. ${ }^{314}$

Ribadeneyra's marginalia as a bibliographical enterprise received greater credibility through the inclusion of two books in his "universal library": Johannes Trithemius's De scriptoribus ecclesiasticis and Sixtus of Siena's Bibliotheca sancta. ${ }^{315}$ While present in Ribadeneyra's Flos, these works were never mentioned or cited in Villegas's redaction. Trithemius was a Benedictine monk of the fifteenth and sixteenth century that compiled a list of religious authors and their biographies as well as titles. Trithemius's labours were far more exhaustive than any similar medieval catalogue. ${ }^{316}$ Sixtus, meanwhile, was a Dominican scholar who compiled a list of sacred writers and their texts, while criticising Protestant misuse of these authors such as the Church Fathers. Sixtus's indictment concerned the Protestant ignorance of chronology, which he

${ }^{314}$ Elizabeth L. Eisenstein, The Printing Press as an Agent of Change: Communications and Cultural Transformations in Early-Modern Europe, 2 vols. (Cambridge: Cambridge University Press, 1979), 1:97-98; Nelles, "Reading and Memory," 154-59. Traditionally, historians have portrayed Gesner and his Protestantism as the antithesis of the Catholic Possevino. Instead of relying on such a binary, I wish to suggest that compiling bibliographies was an emerging practice in early modern Europe.

${ }^{315}$ The entire listing of books can be found in Appendix 6: The Annotations from Ribadeneyra's Flos Sanctorum. For comparative purposes, the marginalia from Villegas features in its own appendix, Appendix 7: The Annotations from Villegas's Flos Sanctorum.

${ }^{316}$ Noel L. Brann, The Abbot Trithemius (1462-1516): The Renaissance of Monastic Humanism (Leiden: Brill, 1981), 204-28; Eisenstein, 1979, 1:94-95. See Johannes Trithemius, De scriptoribus ecclesiasticis (Basel: Amerbach 1494). 
tried to illuminate in his bibliographical work ${ }^{317}$ The Jesuit Robert Bellarmine also participated in a project similar to Sixtus though on a reduced scale ${ }^{318}$

For Ribadeneyra, his saints' lives and his marginalıa mediated between the biobibliographical exhaustiveness of Trithemius and Sixtus's preoccupation with chronology ${ }^{319}$ Akın to the genealogy of virtue apparent when comparing the lives of saints and Jesuits, Ribadeneyra created a lineage of texts upon which he built his exemplary lives ${ }^{320}$ This ordering of time and books was inherent to the structure of the Flos sanctorum itself through its adherence to the liturgical year The tracing of textual predecessors resembled the determination and in some cases creation of heredities found in limpienza de sangre or trajectories of James the Greater's impact on Spanısh history ${ }^{321}$ During Mercurian's tenure as Superior-General, the Society's admittance of conversos became a polarısing affair within the order and indicative of European preoccupations with genealogical constructions ${ }^{322}$ Ribadeneyra, himself, was not concerned with these

317 Irena Dorota Backus, Histortcal Method and Confessional Identity in the Era of the Reformation (Leiden and Boston Brill, 2003), 212-18 See Sixtus of Siena, Btbliotheca santa (Venice Francesco Francesc1, 1566)

${ }^{318}$ Backus, Historical Method, 227-32

${ }^{319}$ Ribadeneyra, Flos (1599), sig Tif 5r "Al qual comunme[n]te yo segurre, principalmente en lo que toca a los años, y trempo en que cada Santo viuio y murı, porque me parece q[ue] ha puesto mas cuydado y dilıgencia que otros, en aueriguar la Chronologia de los tiempos"

${ }_{320}$ This concept of genealogy derives from Gabrielle Spiegel, "Genealogy Form and Function in Medieval Historical Narratıve," History and Theory 22, no 1 (February 1983) 43-53 The practice also manifested in early modern historiography For instance, see Ditchfield, Liturgy, 287-327, Anthony Grafton, What was History? The Art of History in Early Modern Europe (Cambridge Cambridge University Press, 2007), 141-65 The preoccupation with genealogy and history is another manifestation of the confessionalisation of time Ditchfield, Liturgy, 320 "this importance of the accuracy of dates to discussions of saints' feasts helps to explain just why chronology occupied such a central place in Tridentıne history writıng"

${ }^{321}$ Rowe, 37-38, Katherine Ellıott van Liere, "The Moorslayer and the Missionary James the Apostle in Spanish Historiography from Isidore of Seville to Ambrosio de Morales," Viator 37 (2006) $519-43$

${ }^{322}$ Astrain, 3 589-97, Bangert, History of the Soclety, 61, 97-101, Maryks Astrain and Bangert report the changes from pro to anti-converso attitudes in the Society, but Maryks examines the causes or the developments of this policy Maryks illustrates the support for conversos to join the Society in the tenures of Ignatıus, Laynez (of converso descent), and Borgia Ignatıus's admınistratıve muscle, Nadal, also had Jewish heritage At a town he stayed at, its Jews asked Nadal to become therr Rabbi due to his fluency 
earthly ties, but with spiritual lineages that bridged the Society with the early Church ${ }^{323}$ Through his Flos sanctorum, Ribadeneyra sought to make saints' lives conform to a sense of orthodoxy through expunging anything dissonant with Catholicism, whether by well-intentioned Catholics or heretics ${ }^{324}$ When he described his citation of souices, Ribadeneyra directed the reader to consult the books printed by the Typographia Vaticana, the printing operation associated with the Vatican Library The main concern, however, of Ribadeneyra's history was to direct the reader towards orthodox virtue through the imitation of the lives of saints ${ }^{325}$

A parallel to Possevino's bibliographical project, Ribadeneyra by means of marginalia provided a list of books to be read by the fatthful At the same time, the unıversal library also created a sense of confessional tradition through a universal history The reading and writing of history was an integral part of Jesuit education and spiritual life, whether reading or lecturing on Roman and ecclesiastic histories as well as

at Hebrew and Jewish background' During Mercurian's time as Superior-General is when the discord in the order accelerated over the admittance of conversos into the Society and saw the start of ant1-Judaic discrimination The next Superior, Acquaviva, also promoted the anti-converso agenda and forbade conveiso novices by the late-1580s Maryks also illustrates the dissenting voices in the order against such polıcies including Ribadeneyra, Antonıo Possevino, and Juan de Marıana

${ }^{323}$ Maryks, 189

${ }^{324}$ Ribadeneyra, Flos (1599), sıg If $3 \mathrm{r}$ "Siempre se ha tenido en la Yglesıa Catolica por ocupacion de mucha loa y estıma, el escriuir vidas de Santos, assi por las grandes vtılidades que de la leccion dellas se deriua[n] en todos los que las leen con desseo de aprouecharse, como por las muchas y gra[n]des dificultades que se ofrecen a qualquiera que las prete[n]de bien escriur Especialmente que muchos hereges procuraron sembrar sus falsedades en las vidas de los Santos y tambien algunos Catolicos, o por sus interesses, o por su zelo indiscreto, fingieron y mezclaron otras, indignas de la piedad Christiana"

${ }^{325} \mathrm{Ibid}$ sig qf $5 \mathrm{r}$ "Y el alegar sus obras, y citar los lugares, sera segun la impression Romana en folio, de la Typographia, o empre[n]ta Vaticana Y porque no es mi intento principal en esta historia, abarcar, nı referır todo lo que esta escrito de los Santos, sino escoger y entresacar las cosas ciertas y aueriguadas, y las que mas nos pueda[n] mouer a la imitacion de los mismos Santos, cuyas vidas escriuimos, dexare algunas cosas, que aunque esten muy recebidas entre la gente comun, no me parece que estan tan bien fundadas, ni con tanta autoridad, que yo las pueda afirmar" A case study on the Typographica Vaticana involving the printing of Baronıus's Ecclesiastic Annales, see Peter J A N Ruetbergen, "Printing Baronıus's Annales Ecclesiastıcı (Rome, 1588-1607)," Quaerendo 13, no 2 (1983) $87-102$ 
composing the annals of the Society or its sacred biographies ${ }^{326}$ After 1588, Superior General Acquaviva decreed that members of the order could produce only sacred histories As in the case of the Jesuit Jerónımo Román de la Higueia, fa1lure to comply with Acquaviva's mandate implied that the work was not printed and potentially had only a limited curculation ${ }^{327}$ These situations however weie negotiable evident in a case from Rıbadeneyra's writıng career The local Jesuit Superıor refused Rıbadeneyra permıssıon to publish his Historia eclesiastica due to its potential promotion of heretical ideas despite the history's aggressive ant1-Anglicanısm As a result, Ribadeneyra assembled an advisory committee (that also rejected 1t), before writing to Acquaviva explainıng his situation Acquaviva responded by granting his permission for the book to be produced Afterwards the brothers who had decried the work complemented Ribadeneyra and his historical contribution ${ }^{328}$ The preoccupation with religious history in the Society of Jesus included many genres, such as scriptural commentary, secular histories, epistolary collections, martyrologies, chronicles, and hagıographies Sacred histories by Jesuits had to negotiate between the order's authorities and the Jesuit writer

Broadly, the works in the margins of the Flos sanctorum are divisible into two categories The first category is the utılitarian texts that supported Jesuits in their ministries, in education, and in their institutional lives, such as scriptural commentary, as well as collections of letters and sermons The second vanety is historical works that provided not only examples of doctrine in practice, but also the long-standing traditions across time These categorisations are porous since books can serve several functions,

\footnotetext{
326 Nelles, "Historia," 144-55

${ }^{327}$ Kagan, Clio and the Crown, 259-61 A lack of printing does not cause limited circulation It is the disobeying of a superior of the Society that thwarts enthusiasm for a work to be read by other Jesuits

${ }^{328}$ Bilınkoff, "Ribadeneyra", 192-93
} 
such as the Bible, which is a work of history, theology, and devotion. Ribadeneyra through his employ of these different genres created a universal library depicting the universal history of the universal Church albeit in the Flos sanctorum's marginalia. As a writer of officially and unofficially sanctioned saints' lives, Ribadeneyra not only contributed to this creation of an all-encompassing Catholic history but also a sense of community built upon a common spiritual heritage.

The text that preceded all others was the Bible. As a source, the Bible featured extensively in the Flos sanctorum's lives of biblical figures while references to it abounded in the hagiographies of non-biblical saints. Works of biblical commentary usually accompanied many of Ribadeneyra's scriptural annotations and references. Preachers consulted commentaries to assist in their composition of sermons and interpretation of the Bible. Examples included the commentaries by Bede, Jerome, John Chrysostom, and the Jesuits Juan Maldonado and Alfonso Salmerón. ${ }^{329}$ With respect to the Flos sanctorum, Villegas employed the exegetical texts of Jerome, John Chrysostom, Gregory the Great, and Bede. For Gregory, Villegas refered to the pope-saint's Magna Moralia, which was also an exegesis on Job. The genealogy in Villegas's compilation included writers that spanned the fourth to the eighth centuries.

Ribadeneyra, meanwhile, manufactured a consistent timeline of Biblical commentators into the sixteenth century, a practice extended to other facets of this universal history and library. The Jesuit started with Villegas's list and then extended it in both directions. Ribadeneyra began his genealogy with Origen of Alexandria (second and

${ }^{329}$ Prieto Bernabé, 1:233, 236. Commentaries, however, do not appear in the books read by Madrileños in the Golden Age. Only Chrysostom's commentaries appear amongst those frequently read due to its inclusion in a popular opera omnia. The Bible was also very popular and was printed in early modern Madrid in numerous editions. Reading and writing based on the works of the Church Fathers were common practice in the Society, see Nelles, "Du savant au missionnaire," 682-87. 
third centuries) and culminated it with the sixteenth-century commentaries of Martin Luther (listed as Aretius Catharus) as well as the Jesuits Alfonso Salmerón and Juan Maldonado. ${ }^{330}$ While Ribadeneyra created a relatıvely seamless and text-based timeline, there was an extensive void between the periods of Bede and Anselm (see Figure 6, starting on page 118). Ribadeneyra also used more frequently the commentaries of Bede, Jerome, Chrysostom, Maldonado, and Salmerón, perhaps indicative of the works he perused with greater intensity. An institutional identity also emerged from this genealogy through situating the Society within a written tradition that extended back to the New Testament. This long-standing practice included the commentaries of the nascent Church as well as its doctors.

Ribadeneyra, Villegas, and preachers read collections of sermons as a supplement to commentaries as they provided preachers ideas for their own sermons. Sermons also served as models of pious living for readers who were not preachers. Villegas used the compilations of sermons by Basil the Great, Ambrose of Milan, John Chrysostom, Leo I, and Peter Damian. With the exception of Peter Damian (active in the eleventh century), Villegas used the texts by figures of the fourth and fifth centuries. Chrysostom and Peter Damian had also featured in Surius's compilation. Ribadeneyra took Villegas's foundation and expanded upon it to craft a genealogy that began with Origen of Alexandria in the second century and ended with Bernard of Clairvaux in the twelfth. ${ }^{331}$

${ }^{330}$ Hans R Guggisberg, Sebastian Castello, 1515-1563 Humanist and Defender of Religious Tolerance in a Confessional Age, trans Bruce Gordon (Aldershot Ashgate, 2003), $94 \mathrm{n} 81$ The name Aretıus Catharus, or Virtuous Pure, was a pseudonym for Martın Luther.

${ }^{331}$ The entıre list Origen of Alexandria, Eusebius of Emesa, Gregory Nazianzus, Basıl the Great, Gregory of Nyssa, Ambrose of Milan, John Chrysostom, Augustıne, Peter Chrysologus, Maxımus of Turın, Leo I, Gaudentius of Brescia, Fulgentius of Ruspe, Sophronıus, Nicetas the Paphlagonıan, Peter Damian, and Bernard of Clarrvaux 
Examples of frequently-read collections of sermons included ones by Chrysostom, Augustine, and Ambiose 332

While Ribadeneyra maintained the chronology for the commentaries into the sixteenth century, he handled sermons differently The preachers most frequently employed by Ribadeneyra were of the fourth and the fifth centuries Amongst the anthologies of sermons, Ribadeneyra used none after Bernard In part, the lack of sermons after the twelfth century was perhaps indicative of the Jesuits' desire to return to a style of preaching not practiced since late Antınquity and the early Middle Ages, evident in the preponderance of texts from the fourth and the fifth centuries These centuries were also the age of defining orthodoxy in Christianity through the Seven Ecumenical Councils starting with Nicaea in 325 Ribadeneyra through the inclusion of texts depicted the traditions that Jesuits and Catholics ought to adopt while recalling an age of a universal Church definıng orthodoxy

The other practical variety of texts was epistolary compilations, important to Jesuit religious life through their predominant place in institutional affairs Letters were meant to edify and encourage other Jesuits, the most famous example was the dispersal and consumption of Francis Xavier's correspondence ${ }^{333}$ Letters were comparable to biographies as epıstolary collections read in their entirety as they relate to the letter writer's life ${ }^{334}$ Villegas employed two collections of letters in his Flos sanctorum, those of Jerome and Dorotheus of Gaza Ribadeneyra's Flos does not feature Dorotheus, but akin to the collections of sermons, the texts were mostly from fourth and the fifth century

${ }^{332}$ Prieto Bernabe, $1231-32,236$ Only Augustme's sermons were printed outright, Ambrose, Augustıne, and Chrysostom's featured in complete works by theır respectıve authors Augustıne in early modern Spain was frequently printed

${ }_{333}^{334}$ Lazar, 305 Friedrich lists printed compilations of Jesurt letters, 35-37

334 Palomo, "Corregir Letras," 361-69 
writers. Moreover, Ribadeneyra's genealogy of letters only extended from the first to the seventh centuries spanning Ignatius of Antioch until Gregory the Great. ${ }^{335}$ Ribadeneyra's reading habits reflected trends of sixteenth and seventeenth-century Spain, when the letters of Augustine, Gregory the Great, and Jerome were quite popular. ${ }^{336}$ Numerous Jesuits produced editions of religious letters, such as for Jerome (Peter Canisius and Andreas Schott) and Paulinus of Nola (Herbert Roseweyde and Fronton du Duc). ${ }^{337}$ As evident from these texts, Ribadeneyra created genealogies that reified their place within a tradition, such as the continuity of biblical commentaries into the sixteenth century. These genealogies also justified genres of texts, such as correspondence and sermons, as a component that contributed to orthodoxy through Ribadeneyra's consumption of fourth and fifth-century writers of letters and sermons.

While the genealogies of professional works lend themselves to easy categorisation, the histories are much more difficult to assess due to the considerable overlap between genres of historical writing. History did not refer exclusively to a critical inquiry of the past; it included other narratives, such as sacred and secular biographies. These approaches coalesced into a universal history of Christianity through Ribadeneyra's construction of genealogies of texts, which constructed a sense of religious tradition. In turn, these works constituted a universal library for the universal Church that began with the Bible and its depictions of the primitive church. The genealogy of historical texts assembled by Ribadeneyra created a selective continuum spanning church

\footnotetext{
335 Ribadeneyra read the epistolary collections of Ignatius of Antioch, Hyginus, Cyprian, Athanasius, Jerome, Paulınus of Nola, Augustıne, Severus Sulpıcıus, Innocent I, Attıcus, Celestıne I, Prosper of Aquitaine, Hilary of Arles, and Gregory the Great.

336 Prieto Bernabé, 1:233, 238-39. While Jerome and Augustine's letters were printed as standalone tomes, Gregory's letters only appeared in his complete works.

${ }^{337}$ Bertrand, 896, 903, 908 .
} 
history from the first to the sixteenth centuries. The gaps in texts and in saints were medieval in particular those from the High Middle Ages While Ribadeneyra never mentioned any contempt for the writings of this era, Baronius in his Annales ecclestastict described the period starting with $900 \mathrm{CE}$ as a "dark age" due to the lack of available writings providing light. ${ }^{338}$ Apart from scripture, texts from the early centuries of the Church employed by Ribadeneyra were works of Roman historians and early Christian theologians such as Hippolytus of Rome. ${ }^{339}$ Four distinct clusters of histories existed in this universal library of Catholic history that imitated Roman authors cited by Ribadeneyra: chronicle (Tacitus), general history (Cassius Dio), biography (Suetonius), and martyrology (Hippolytus of Rome).

The chronicle cluster modelled on Tacitus's Annals was rigidly chronological and focused on an institution or a locality from the entity's foundation until the present day of the author. ${ }^{340}$ Both Villegas and Ribadeneyra employed the chronicles by Datius of Milan and the Dominican Antonino de Pierozzi. ${ }^{341}$ Independent of Ribadeneyra, Villegas used

${ }^{338}$ Cesar Baronıus, Annales Ecclelastıci, 10 vols (Rome Typographıca Vatıcana, 1588-1602), 10. 647 "En incipit annus Redemptorıs nongentesımus, tertı Indictionıne notatus, quo \& nouum inchoatur saeculum, quo fuı asperitate ac bonı sterilitate ferreum, malıq[ue] exundantıs deformitate plumbeum, atque inopia sciptorum appellari consueuit obscurum "Baronius's Annales explore the history of the hierarchical church from its inception to 1198 . While Ribadeneyra's Flos sanctorum initially dates from 1599, this conception of Baronius would not be unknown to Rubadeneyra as part of the milieu of sacred historians. Ribadeneyra obviously followed Baronius's chronology closely $1.232-47$

${ }^{339}$ For an overview of Hippolytus of Rome and his writıngs, consult Moreschını and Norell,

${ }^{340}$ Sarah Foot, "Finding the Meanıng of Form $\cdot$ Narrative in Annals and Chronicles," in Writung Medieval History, ed. Nancy Partner (London Hodder, 2005), 88-108 Foot's prece was engaging, succinct, and helpful guide to differentrating between annals and chronicles The confusion abounds due to the lack of consistency in naming these works. Keeping pace with Foot, the chronicle makes some attempts at correlatıng the sequential events, whereas the annal conveys contınuity for its own sake History expands upon the chronicle to form an expansive interpretation of the past All of these historiographies possess narratıve, especially when read in their entırety While histories eventually end, chronicles and annals can perpetuate These approaches to history only require another chronicler or annalist to attach the events of subsequent years The preoccupation with time and the creation of tradition and identity through text resonate with this investigation.

${ }^{341}$ Jean-Chrétien-Ferdınand Hoefer, Nouvelle biographie générale depuis les temps les plus reculés jusqu'à nos jours, 46 vols (Parıs' Firmın Didot Frères, 1853-66), 12 753-54, John Bernard Walker, 
the chronicles of the Augustinian Onofrio Panvinio and Marcantonio Sabellico. ${ }^{342}$ While Villegas's selections betrayed a preference for writers of recent memory, Ribadeneyra opted for the genealogical route. The Jesuit's textual lineage finished with Baronius's Annales ecclesiastici. Apart from the chroniclers already mentioned, Ribadeneyra read a myriad of chronicles, which he incorporated into the Flos sanctorum. His genealogy of this historical genre included Byzantine, mendicant, and popular medieval chronicles. ${ }^{343}$ Ribadeneyra also read contemporary chroniclers, such as Morales. Ribadeneyra's reading habits echoed those of early modern Spaniards evident in his adoption of the practices found in the favoured chronicles by Baronius and Morales. ${ }^{344}$ One discernible omission is Jerome's chronicle, an intercessor between Eusebius and Prosper of Aquitaine. ${ }^{345}$ While the Jesuits had their own chronicle by Polanco, no Jesuit annals or chronicles featured in Ribadeneyra's saints' lives, perhaps because it remained unpublished in Ribadeneyra's lifetime. ${ }^{346}$ Another Jesuit, Pierre Madur, had edited Antonino's Chronicle. ${ }^{347}$ The

The "Chronicles" of Saint Antoninus: A Study in Historiography (Washington, D.C.: Catholic University of America, 1933), 3-18, 37-52. Datius of Milan was a sixth-century Archbishop of that city, the manuscript history attributed to him (Ribadeneyra and Villegas also do the same) was of much later provenance. Antonino de Pierozzi or Antoninus of Florence (1389-1459) was a Dominican friar, well known for his confessor manuals and his chronicle.

${ }^{342}$ Peter Godman, The Saints as Censor: Robert Bellarmine between Inquisistion and Index (Leiden: Brill, 2000), 125-29; Margaret L. King, Venetian Humanism in an Age of Patrician Dominance (Princeton: Princeton University Press, 1986), 425-27. Marcantonio Sabellico (1436-1505) was a noted humanist historian based in Venice. Onofrio Panvinio (1529-1568) was a Roman historian and librarian to Cardinal Farnese as well as an Augustinian friar. While Panvinio had been the preeminent chronicler of the Church, the Jesuit Bellarmine had revealed Panvinio's errors and criticised Panvinio's chronology.

${ }^{343}$ Ribadeneyra read the Byzantine chronicles of Nicephoros I of Constantinople and George Cedrenus. He also preferred the chronicles of the Dominicans (Antonino de Pierozzi) and the Franciscans. The popular medieval chronicles include the ones by Eusebius, Prosper of Aquitaine and Marianus Scotus.

344 Prieto Bernabé, 1:233, 324.

345 A discussion on the continuity between the chronicle tradition of Eusebius-Jerome-Prosper followed by Orosius then Bede and Isidore of Seville, see Michael I. Allen, "Universal History 300-1000," in Historiography in the Middle Ages, ed. Deborah Mauskopf Deliyannis (Brill: Leiden and Boston, 2003), 23-35.

${ }^{346}$ Polanco's Chronicon was the first work published by the Monumenta historica Societatis Iesu in 1894. Juan-Alfonso de Polanco, Vita Ignatii Loiolae et rerum Societatis Jesu historia, 6 vols. (Madrid: Typographorum Societas, 1894-98). MHSI 1, 3, 5, 7, 9, 11.

${ }^{347}$ Bertrand, 899. 
Society was scarcely sixty-years old when Ribadeneyra's Flos first appeared in 1599.

The rise of church history was perhaps part of Acquaviva's interest in promoting the Society's written culture. It also indicated a concerted effort to integrate the Society into early modern Catholicism.

Meanwhile, the grouping of general histories mimicked Cassius Dio's Roman History. These works were also chronological and preoccupied with institutions as well as localities. Yet Cassius-inspired histories, dissimilar from chronicles, sought to explore the motivations of historical persona akin to Thucydides. ${ }^{348}$ Notable examples of this historiographical approach by Jesuits include Juan de Mariana's Historiae de rebus Hispaniae and Ribadeneyra's history of the English 'schism'. ${ }^{449}$ From this historical genre, both authors used the histories of Eusebius, Pseudo-Hegesippus, and Nicephorus Callistus Xanthopulus. Surius also employed Eusebius and Pseudo-Hegesippus in his compilation of saints' lives. Dates for the majority of the historians cited and read by Ribadeneyra ranged from the third to the eighth century. ${ }^{350}$ Ribadeneyra did not read any general histories from the eighth to the fourteenth century, either indicative of the changes in historiography or his assessment of this type of history from that period. The tendency towards reading Byzantine histories persisted through the appearance of Nicephorus, whose Ecclesiastic History was a popular work in early modern Europe and

348 Rosamond McKitterick, History and Memory in the Carolingian World (Cambridge: Cambridge University Press, 2004), 40-50. Cassius Dio was not a widely available Roman historian in the Middle Ages, the preference was for Livy, Sallust, Suetonius, and Tacitus. For Christian and Jewish history, meanwhile, medieval readers preferred Pseudo-Hegesippus, Eusebius, Jerome, and Prosper of Aquitaine. For 'Barbarian' history, the historians widely circulated included Bede, Paul the Deacon, and Gregory of Tours.

${ }^{349}$ DHCJ s.v. N. González, "Mariana, Juan de," 3: 2506-7; Bertrand, 897; Juan de Mariana, Historiae de rebus hispaniae libri $x x$ (Toledo: Pedro Roderigo, 1592). Mariana also compiled an annotated edition of Isidore of Seville's writings.

${ }^{350}$ Walter Goffart, The Narrators of Barbarian History (Princeton, NJ: Princeton University Press, 1988), 8. The listing is as follows: third to fifth centuries (Eusebius, Pseudo-Hegesippus, Paul Orosius, and Theodoret of Cyrus), sixth to eighth centuries (Procopius, Bede, and Paul the Deacon), fourthteenth (Nicephoros), and sixteenth (Fernando del Castillo). 
widely available. ${ }^{351}$ Another bestselling general history read by Ribadeneyra was Fernando del Castillo's History of the Order of Preachers, again pointing towards a preference for mendicant literature and also widely-read by contemporaries. ${ }^{352}$ Cast1llo's History was also indicative of a late sixteenth-century trend to compose histories of the orders in Spain, a practice evident in the Dominicans, Hieronymites, and the Benedictines ${ }^{353}$ Ribadeneyra's reading practices fused texts popular amongst early modern Spanish readers, key medieval works, as well as Byzantine and mendicant ecclesiatical histories.

Biographical expositions of a noted figure comprised the third cluster of religious history, Suetonius in his On the Twelve Caesars established the practice of collecting together numerous biographies Reading Tacitus, Cassius Dio, and Suetonius by a Jesuit were surprising given their absence from Jesuit education ${ }^{354}$ Hagiographies also borrowed from these Suetonian biographies. Autobiographies were also an outgrowth of Suetonius-inspired biography, the most-notable early example was Augustine's Confessions. ${ }^{355}$ That work, along with Bonaventure's Life of St. Francis, and Gregory the Great's Llfe of St. Benedict from the Dialogues were frequently read in late-sixteenth

${ }^{351}$ On the popularity of Nicephorus, see Franco Mormondo, "Pestılence, Apostasy, and Heresy in Seventeenth-Century Rome," in Plety and Plague From Byzantium to the Baroque, eds Franco Mormondo and Thomas Worcester (Kırksville, MO. Truman State Unıversity Press, 2007), 264-71.

${ }^{352}$ Prieto Bernabé, 1321

${ }^{353}$ Roest, 290-305; Bruce Taylor, Structures of Reform The Mercedarian Order in the Spanish Golden Age (Leiden and Boston. Brill, 2000), 418. Also, mendicant orders had long used history (whether general histories or chromicles) and hagiography as the basis of their historical memory

${ }^{354}$ Prieto Bernabé, 1310 . Leonardo Brunı, "The Study of Literature," in Humanist Educational Treatises, ed and trans. Craig W Kallendorf (Cambridge, MA, and London Harvard University Press, 2002), 109, "Ratıo," 387, 395 Jesuits were to read an expurgated Thucydides, Gregory Nazıanzen, Basıl the Great, and Chrysostom in Greek, while in Latın, they were to read Caesar, Sallust, Livy, Curtıus, and Vergil Brun, meanwhile, had advocated for the same Latın authors from the Ratlo, but had also included Tacitus Golden Age Spaniards did not read Cassius, but read Suetonius and Tacitus as a supplement to the reading of Caesar, Sallust, Livy, Curtıus, and Vergil

${ }^{355}$ Frazıer, 20-21; Heffernan, 3-37; Rubensteın, 24-27 
century Spain. ${ }^{356}$ While the practice of reading and writing lives was crucial within the Society, these texts were not only popular amongst Jesuits but were an important part of their spiritual edification. ${ }^{357}$ In addition to Ignatius's autobiography, the lives of Ignatius by Rubadeneyra, Giampietro Maffei, and Daniello Bartoli were important reading in the pious development of Jesuits. Ribadeneyra's life-writing output was extensive through translating Augustine's Confessions as well as writing his own autobiography, the lives of women (such as Doña Estefanía Manrique de Castilla), saints in the Flos sanctorum, and other Jesuits. ${ }^{358}$

Both Ribadeneyra and Villegas cited Possidius's Life of St. Augustine, Simon Metaphrastes's compilation of saints' lives, and Surius. ${ }^{359}$ Both also made reference to Bonaventure's Life of St. Francis, Dietrich of Apolda's Life of St. Dominic, and the lives by Giovanni Garzoni. ${ }^{360}$ The reliance upon Possidius, Metaphrastes, Bonaventure, and Dietrich is of some significance, as these texts were also used by Surius. Ribadeneyra's tendency to read genres of text based on a genealogical schema was also practiced with biographies especially when compared with Villegas. In addition to the aforementioned texts, Ribadeneyra broadened his reading to provide a sense of continuity, a sense of tradition amongst these sacred biographies. Amongst individual lives, Ribadeneyra supplemented his reading with Gregory of Nyssa, John the Deacon of Rome, Antonio

${ }^{356}$ Prieto Bernabé, 1.231, 234, 238.

${ }^{357}$ Lazar, 292, 305-7.

${ }^{358}$ Bllınkoff, Related Llves, 33-35, 39, 42-45; idem, "Rıbadeneyra", 181, G1lmont, Écrlts, 32-33, 272-76, O'Malley, "Histollography," 4-8 In addition to his life of Ignatius, Ribadeneyra also wrote the lives of Jesuits individually (Ignatius, Laynez, Borja, and Salmerón) and as part of the Flos sanctorum (Ignatıus, Xavier, Gonzanga, Kostka, and Borja). The amount of lives written in the first century of the Society is astonishing!

359 An excellent overview of Simon Metaphrastes's life and work as well as hagiographical redactions prior to Metaphrastes can be found in Christian Høgel, Symeon Metaphrastes Rewritıng and Canonization (Copenhagen Museum Tusculanum Press, 2002), 21-88, 127-34

${ }^{360}$ Frazier, 169-219, 395-414. Garzoni was a prolific life-writer with at least thirty lives attributed to him including Augustıne, Catherıne of Alexandria, Domınic, Gregory the Great, John the Apostle, and Thomas Aquinas He also attempted to distance his sacred bıographies from those of Jacobus de Voragine 
Pızamano, Morales, and Baronıus ${ }^{361}$ While Ribadeneyra had cited a Life of St. James by Isidore of Seville, it was a chapter from Isidore's De virts illustribus. ${ }^{362}$ Apart from Surius and Metaphrastes, other collections of lives read by Ribadeneyra included Lippomano and Gregory the Great's Dialogues ${ }^{363}$ Ribadeneyra thus created a textual lineage that spanned most of the church's history, including the sixteenth century as evident in the works by Morales, Baronıus, Lippomano, and Surius Similar tendencies noted previously also manıfested here, most notably the reading of Byzantine biographers (Metaphrastes, Gregory of Nyssa) as well as the works of the mendicant friars (Pızamano, Bonaventure, Dietrich, and Garzonı). The medieval content, however, had minimal exposure. A notable omission from Ribadeneyra's list of hagiographical compilations was Voragine's Golden Legend ${ }^{364}$

The final cluster evident in this universal historical library was martyrological, a list of holy persons that included brief descriptions of their lives, deaths, and contributions to spiritual life ${ }^{365}$ Ribadeneyra began his genealogy of the genre with Hippolytus of Rome's Book of the Seventy Disciples, which provided the names and terse

${ }^{361}$ Bertrand, 907; Christian, 250, Frazier, 453-54, M A Lapôtre, "La Souper de Jean Diacre," Melanges d'archeologie y d'historre 21 (1901). 313-14; The Brill Dictionary of Gregory of Nyssa s v Pierre Maraval, "Chronology of Works," 164, Pullapilly, 210 The specific lives in question are Gregory's life of Gregory Thaumaturgos, John the Deacon of Rome's life of Gregory the Great, Antonio Pizamano's life of Thomas Aquinas, Morales's life of Justus and Pastor, and Baronius's life of Ambrose The first printing of Morales's vita was in 1568 from Alcalá by Andres de Angulo A Jesuit, Fronto Ducaeus, had edited the complete works of Gregory of Nyssa Baronius's life of Ambrose featured in his complete works

${ }^{362}$ The following is the life of James the Great found in Isidore of Seville, "De ortu, \& obitu Patrum," in Opera, 2 vols (Madrid. Imprenta Real, 1599), 1 sig †252 "Iacobus filius Zebedaeı, frater Iohannis, quartus in ordine, duodecim tribubus quae sunt in dispersione gentıum scripsit, atq[ue] Hispaniae $\&$ occidentalıum locoru[m] gentibus Euangelıum praedicaut, \& in occasu mundi lucem praedicationıs inrudit Hic ab Herode Tertrarcha gladıo caesus occubuit Sepultus in Marmarıca "

${ }^{363}$ While the Dialogues only features one biography (the life of St Benedict), Gregory's work is a series of expositions on the saints and their virtues reflecting similar tendencies in later redactions

${ }^{364}$ Thompson, 105-6.

${ }^{365}$ Michel Sot, "Local and Institutional History (300-1000)," in Historiography in the Middle Ages, ed Deborah Mauskopf Deliyannis (Brill Leiden and Boston, 2003), 92-94 Sot situates them as an offshoot of Eusebius's Chronicle 
descriptions of the disciples. His choice in martyrologies reflected the development of the genre becoming based on historical narratives and increasingly descriptive Early modern Spanish readers favoured Isidore's martyrological De ortu et orbitu Patrum as well as the Roman Martyrologies, whether edited by Baronius or not. ${ }^{366}$ Villegas in his Flos sanctorum only used the Roman Martyrology printed in 1585. Jesuits were also interested in vernacular martyrologies, evident in Peter Canisius's German translation. ${ }^{367}$ This genre differed from the others through its lack of Byzantine and mendicant friar sources as well as having a widely dispersed genealogy. From Hippolytus onwards, Ribadeneyra included in his textual lineage: Gregory of Tours's On the Glory of the Martyrs, Isidore, Bede, Ado, Usuard, Francesco Maurolico, and the sixteenth-century Roman Martyrologies ${ }^{368}$ The lack of martyrologies from the ninth until the sixteenth century that spanned the period between Usuard and Maurolico's martyrologies could be the result of the immense popularity of Usuard's text in the intermittant period. ${ }^{369}$ Akin to the other historical genres, Ribadeneyra formed a broadly-scoped history infused with a tradition

366 Prieto Bernabé, 1·238, 240, Moreschını and Norellı, 2 530-32, Van Liere, 523-26. Prieto Bernabé does not specify which Roman Martyrology (the one edited by Baronius or not) as the most frequently read Isidore of Seville's Fathers of the New Testament and On the Lives and Deaths of Saints were sections of his De ortu et orbitu Patrum, a brief list of saints' deeds and deaths Early modern Spaniards would have read this work in the popular opera omnıa of Isidore.

${ }^{367}$ DHCJ s v P. Begheyn, "Canisius, Pedro," 1: 633-35, Gilmont, Écrits, 218-19. Canisius was also a life-writer, most notably of saints Fridolın, Ida, Beatus, as well as Maurıce, Ursus, and their companions.

${ }^{368}$ On Gregory of Tours, consult Raymond van Dam's introduction in Gregory of Tours, Glory of the Martyrs, trans. Raymond van Dam (Liverpool: Liverpool University Press, 1988), 1-17, especially 5-8 On Bede and Ado, see Henrı Quentın, Les martyrologes historiques du moyen âge (1908 Reprınt, Darmstadt. Scientia Verlag Aalen, 1969), 17-18, 47-56, 465-81 On Usuard and his use of previous martyrologies such as Jerome, Bede, and Ado, refer to Jacques Dubois, Le martyrologe d'Usuard Texte et commentaire (Brussels. Socıété des Bollandıstes, 1965), 41-52, 103-37 Francesco Maurolico was a Benedictine mathematician who used his knowledge to compose a martyrology, first published in 1567 Edward Rosen, "Maurlico's Attıtude toward Copernicus," Proceedings of the American Philosophical Soclety 101, no. 2 (April 1957) 189 On the Roman Martyrologies 1ssued in the late-sixteenth century and its antecedents, see Ditchfield, Liturgy, 43-52

${ }^{369}$ Quentin, 675-77 The sheer volume of extent copies of Usuard's Martyrology is suggestive, but not indicatıve, of its popularity 
formed by a textual geneaology. In turn, the creation of this tradition as well as a collection of orthodox texts fostered a religious community of readers.

These assembled works facilitated the creation of a confessional identity amongst Jesuits and Catholics by providing a universal library. This universal library without walls held volumes of scriptural commentary, epistolary collections, as well as sacred histories. History was a guide to confessional conduct as well as a guide to sanctity and saints' cults. Through the Flos sanctorum's marginalia, Ribadeneyra showed his readers the works he consulted and the writings that he imitated in composing his sacred biographies. As a result, readers imitated the reading habits of the hagiographer as well as the pious behaviour of a hagiography's saint. In turn, the communication networks facilitated by multimedia promoted and reified a sense of community. The result was not a single identity but several overlapping identities of Catholics that negotiated sacred spaces, biographies, and communities. In the case of Ribadeneyra, he was a member of numerous confessional reading communities, whether as a Castillian, a Madrileño, or a Jesuit. At the same time, Ribadeneyra created a sense of continuity between the early Church and post-Tridentine religious life by crafting a sense of religious tradition. Ribadeneyra included himself in the practice of crafting sacred history for an early modern community of Christians who felt that their confession was an authentic continuation of the apostolic church. All other confessions were heresies that distorted divine truth. Just as an angelic voice had told Augustine to "take it and read", Ribadeneyra incited the Flos sanctorum's readers to do the same and to replicate the practices embedded within the text. 
Figure 6: Textual Geneologies of Flos sanctorum based on Appendices 6 and 7

\section{Biblical Commentaries}

\begin{tabular}{|c|c|c|}
\hline Villegas & Ribadeneyra & Centuries \\
\hline $\begin{array}{l}\text { Jerome. Commentaries } \\
\text { John Chrysostom. Commentaries } \\
\text { Gregory the Great. Moralityor a } \\
\text { Commentary on Job } \\
\text { Bede. Commentaries }\end{array}$ & $\begin{array}{l}\text { Origenof Alexandria, Commentaries } \\
\text { Victorinus of Poetovio, Commentaries } \\
\text { Hilary of Poitiers, Commentaries } \\
\text { Ambrose of Milan, Commentaries } \\
\text { Rufinus, Commentarius in symbolum } \\
\text { apostolorum } \\
\text { Jerome, Commentaries } \\
\text { John Chrysostom, Commentaries } \\
\text { Theodore the Interpreter, Commentaries } \\
\text { Augustine, Commentary on John } \\
\text { Pseudo-Dionysius the Areopagite, On the } \\
\text { Letter to John } \\
\text { Primasius, Commentaries } \\
\text { Gregory the Great, Moralityor a } \\
\text { Commentary on Job } \\
\text { Bede, Commentaries } \\
\text { Anselm, Commentaries } \\
\text { Theophylact of Ohrid,Commentaries } \\
\text { Rupert of Deutz, O.S.B., Commentaries } \\
\text { Euthymius Zigabenus, Commentaries } \\
\text { Thomas Aquinas, O.P. Commentary on } \\
\text { John } 21 \\
\text { Nicholas of Lyra, Commentaries } \\
\text { Aretius Catharus[=Martin Luther], } \\
\text { Commentary on } 2 \text { Corinthians } \\
\text { Alfonso Salmerón, S.J., Commentaries } \\
\text { Juan Maldonado, S.J., Commentaries }\end{array}$ & $\begin{array}{l}1^{\text {st }}-2^{\text {td }} \\
3^{\text {td }}-4^{\text {th }} \\
4^{\text {th }} \\
4^{\text {th }} \\
4^{\text {th }}-5^{\text {th }} \\
4^{\text {th }}-5^{\text {th }} \\
4^{\text {th }}-5^{\text {th }} \\
4^{\text {th }}-5^{\text {th }} \\
4^{\text {th }}-5^{\text {th }} \\
5^{\text {th }}-6^{\text {th }} \\
6^{\text {th }} \\
6^{\text {th }}-7^{\text {th }} \\
7^{\text {th }}-8^{\text {th }} \\
11^{\text {th }}-12^{\text {th }} \\
11^{\text {th }}-12^{\text {th }} \\
11^{\text {th }}-12^{\text {th }} \\
11^{\text {th }}-12^{\text {th }} \\
13^{\text {th }} \\
13^{\text {th }}-14^{\text {th }} \\
15^{\text {th }}-16^{\text {th }} \\
16^{\text {th }} \\
16^{\text {th }}\end{array}$ \\
\hline
\end{tabular}

\section{Sermons, Orations, and Homilies}

\begin{tabular}{|l|l|l|}
\hline & Origenof Alexandria.Sermons & $1^{\text {st }}-2^{\text {nd }}$ \\
& Eusebius of Emesa, Book of Homilies & $4^{\text {th }}$ \\
& Gregory Nazianzus, Orations & $4^{\text {th }}$ \\
& Basil the Great, Sermons & $4^{\text {th }}$ \\
Ambrose of Milan.Sermons & Gregory of Nyssa,Sermons & $4^{\text {th }}$ \\
& Ambrose of Milan, Sermons & $4^{\text {th }}$ \\
John Chrysostom. Sermons & John Chrysostom. Orations & $4^{\text {th }}-5^{\text {th }}$ \\
& John Chrysostom. Sermons & $4^{\text {th }}-5^{\text {th }}$ \\
Leo I. Sermons & Augustine. Sermons & $4^{\text {th }}-5^{\text {th }}$ \\
& Peter Chrysologus,Sermons & $4^{\text {th }}-5^{\text {th }}$ \\
& Maximus of Turin, Sermons & $4^{\text {th }}-5^{\text {th }}$ \\
\hline
\end{tabular}




\begin{tabular}{|l|l|l|}
\hline & Gaudentius of Brescia, Sermons & $4^{\text {th }}-5^{\text {th }}$ \\
& Fulgentius of Ruspe,Sermons & $5^{\text {th }}-6^{\text {th }}$ \\
& Sophronius, Sermons & $6^{\text {th }}-7^{\text {th }}$ \\
& Nicetas the Paphlagonian,Sermons & $10^{\text {th }}$ \\
& Peter Damian, O.S.B.,Sermons & $11^{\text {th }}$ \\
& Bernard of Clairvaux, O. Cist., Sermons & $11^{\text {th }}-12^{\text {th }}$ \\
\hline
\end{tabular}

\section{$\underline{\text { Letters }}$}

\begin{tabular}{|l|l|l|}
\hline \multirow{5}{*}{ Jerome. Letters } & Ignatius of Antioch. Letters & $1^{\text {st }}-2^{\text {nd }}$ \\
& Hyginus. Letters & $2^{\text {nd }}$ \\
& Cyprian.Letters & $3^{\text {rd }}$ \\
& Athanasius. Letters & $4^{\text {th }}$ \\
& Jerome. Letters & $4^{\text {th }}-5^{\text {th }}$ \\
& Paulinus of Nola.Letters & $44^{\text {th }}-5^{\text {th }}$ \\
& Augustine. Letters & $44^{\text {th }}-5^{\text {th }}$ \\
& Severus Sulpicius. Letters & $4^{\text {th }}-5^{\text {th }}$ \\
& Innocent I. Letters & $4^{\text {th }}-5^{\text {th }}$ \\
& Atticus. Letters & $4^{\text {th }}-5^{\text {th }}$ \\
Dorotheus of Gaza. Letters & Celestine I. Letters & $4^{\text {th }}-5^{\text {th }}$ \\
& Prosper of Aquitaine. Letters & $4^{\text {th }}-5^{\text {th }}$ \\
& Hilary of Arles.Letters & $5^{\text {th }}$ \\
& Gregory the Great.Letters & $6^{\text {th }}$ \\
\hline
\end{tabular}

The Universal History of Catholicism

\begin{tabular}{|c|c|c|}
\hline $\begin{array}{l}\text { Pseudo-Hegesippus, De exicidio } \\
\text { Hierosolymitano }\end{array}$ & $\begin{array}{l}\text { Tacitus, Annals } \\
\text { Suetonius, Lives of the Caesars } \\
\text { Cassius Dio, Roman History } \\
\text { Hippolytus of Rome, Book on the } \\
\text { Seventy Disciples } \\
\text { Eusebius of Caesarea, Chronicle } \\
\text { Eusebius of Caesarea, Ecclesiastic } \\
\text { History } \\
\text { Gregory of Nyssa, Life of Gregory } \\
\text { Thaumaturgos } \\
\text { Pseudo-Hegesippus, De exicidio } \\
\text { Hierosolymitano } \\
\text { Prosper of Aquitaine, Chronicle } \\
\text { Paul Orosius, Historyagainst the Pagans } \\
\text { Theodoret of Cyrus, Religious History } \\
\text { Augustine, Confessions } \\
\text { Possidius, Life of Augustine } \\
\text { Procopius, De Bello Gothico } \\
\text { Datius of Milan, Chronicle }\end{array}$ & $\begin{array}{l}1^{\text {st }}-2^{\text {nd }} \\
1^{\text {st }}-2^{\text {nd }} \\
2^{\text {nd }}-3^{\text {rd }} \\
2^{\text {nd }}-3^{\text {rd }} \\
3^{\text {rd }}-4^{\text {th }} \\
3^{\text {rd }-4^{\text {th }}} \\
4^{\text {th }} \\
4^{\text {th }} \\
4^{\text {th }}-5^{\text {th }} \\
4^{\text {th }}-5^{\text {th }} \\
4^{\text {th }}-5^{\text {th }} \\
4^{\text {th }}-5^{\text {th }} \\
4^{\text {th }}-5^{\text {th }} \\
5^{\text {th }} \\
6^{\text {th }} \\
\end{array}$ \\
\hline
\end{tabular}




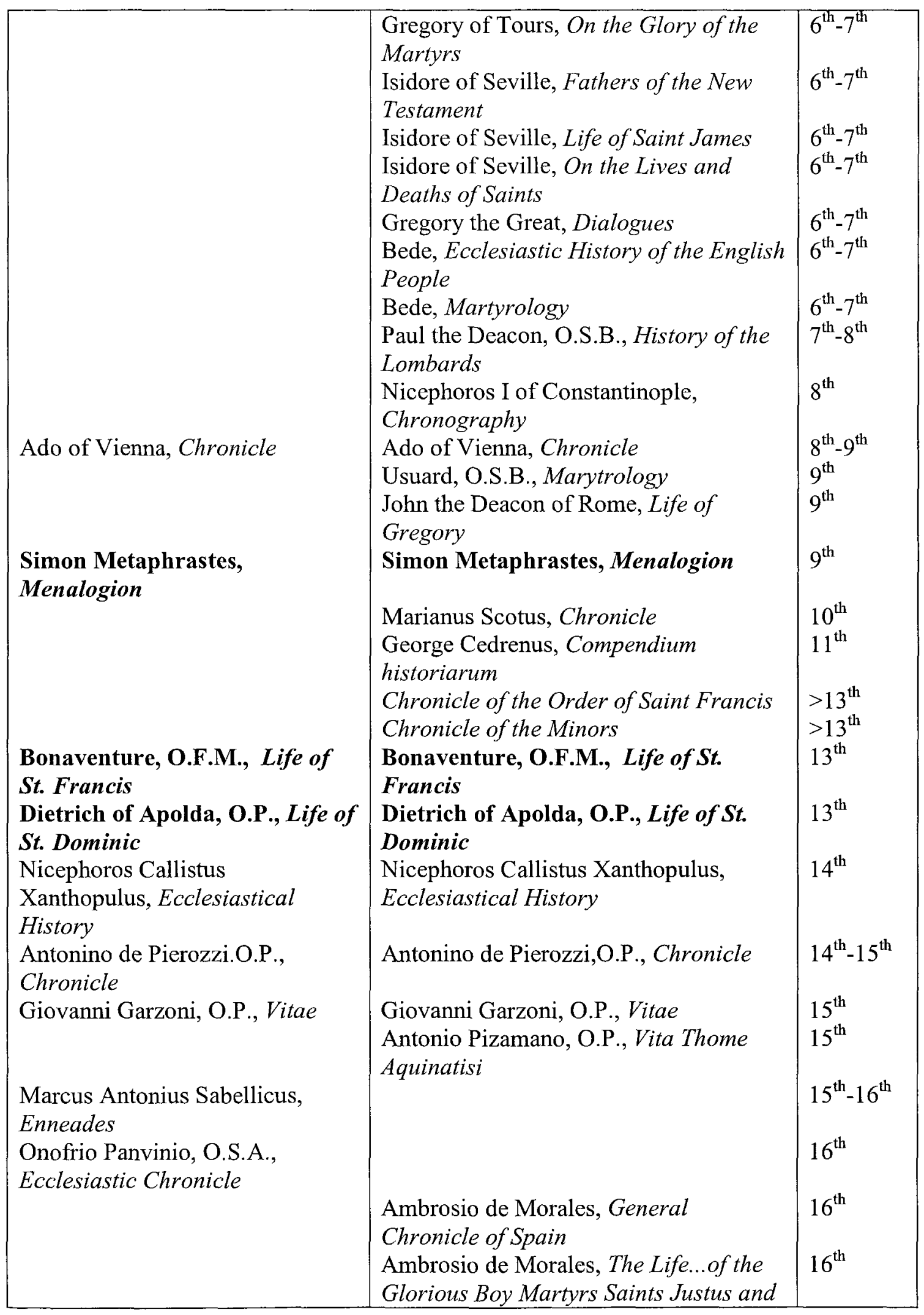




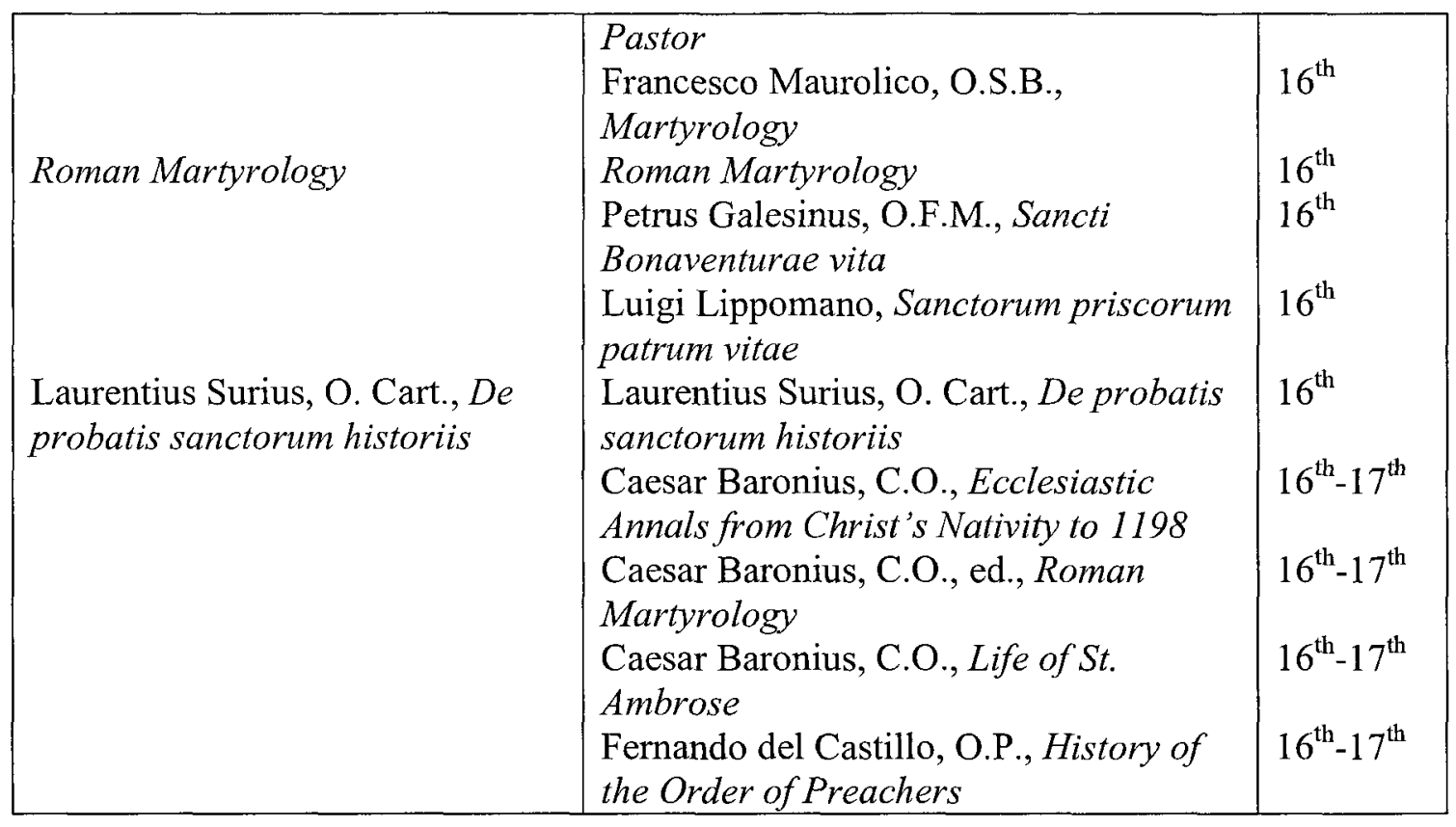




\section{CHAPTER 3: THE SAINT AS EXEMPLAR IN EARLY MODERN CATHOLICISM}

Saints and exemplary Jesuits permeated Ribadeneyra's writings. They functioned

as models of religious conduct, asserted community, and promoted a strong Catholic

identity. Saints were part of God's plan for humanity and for the Church. They combated

heresy and lead Christians to God through the example of their holy actions:

This fact is true, as I have said, of the providence and plan of the Lord, to provide assistance and help to those in the greatest need by opposing a Simon Magus with a St Peter, Prince of the Apostles, an Arius with an Athanasius; a Nestorius with a Cyril; Jovinian, Vigilantius, and Helvidius with a Jerome; Mani and Pelagius with an Augustine, and other enemy heretics with other brave leaders and protectors. The writers of ecclesiastical history rightly observe that the same day that Pelagius was born in England to pervert and darken the world with his errors, in Africa, on that very day, that great sun of the Catholic church, Augustine, was born to undo the darkness of an evil and wicked heretic with his radiance and brilliance. When the Albigensians and other even more depraved heretics disturbed the peace of God's church, and the thorns of vices and evils were fully grown and had drowned the good seed cast by the heavenly Sower, he sent into the world those two seraphim and leading lights of heaven, Saints Dominic and Francis. For Him, His children, and disciples, they resisted the heretics, uprooted errors, corrected sins, and reformed habits. They illuminated and sanctified the universe with their admirable example and doctrine, as did the Holy Fathers and as do presently his children. ${ }^{370}$

As apostles, Church Fathers, and founders of religious orders, saints were manifestations of virtue. They also provided exemplars for Catholics, evident in the constant contrast

370 Ribadeneyra, Vita Ignatıl, 315-17. "Esto es propı (como he dicho) de la providencia y conejodel Señor, socorrer y ayudar a la mayor necessıdad y oponerá Simón Mago un san Pedro, príncipe de los Apóstoles a Arrıo, un Atanasıo, a Nestorio un Cirılo, a JovınıanoVıgılancio y Elvidıo un Gerónımo, a Manes y Pelagio un Augustıno, y a otros hereges enemigos otros valerosos capitanes y defensores Los escritores de la historıa eclesı́stıca con mucha razón advirtıeron que el mismo día que en Inglaterra nacıó Pelag1o para prevertır y escurecer con sus errores el mundo, ese mismo día nació en Africa aquel gran sol de la Yglesıa Católica, Agustıno, para deshacer con sus rayos y resplandor las tınieblas del malvado y perverso herege Quando los Albigenses y otros hereges más desapoder[da]mente turbaban la paz de la Yglesia de Dios y las espınas de los vicios y maldades estaban más crecıdas y ahogavan la buena semılla que avía sembrado el sembrador celestıal, embı́ al mundo aquellos dos serafines y lumbreras del cıelo, santo Domıngo y san Francisco, para que por sí y por sus hıos y dicípulos resistiesen a los hereges, desarraigasen los errores, corrigiesen los pecados, reformassen las costumbres, alumbrassen y santificasen el universo con su admirable exemplo y dotrına, como lo hizieron los Santos Padres y hasta ahora lo hazen sus hijos" 
between orthodoxy and heresy. Saintliness was also continuous, apparent in the genealogy of sanctity Ribadeneyra expounded. This began with Peter and the Apostles followed by the Church Fathers, culminating in the founders of the mendicant orders. Ribadeneyra also attempted to place Jesuits within this cycle of saintly emulation. When defending the publication of a life of Diego Laínez, Ribadeneyra argued that "if [Jesuits] examine the deeds of father Laínez with care and consideration, they will find things so admirable, akin to the things of the other saints of the Society, and perchance more imitable." 371 By the 1590 s, Ribadeneyra casually refers to notable deceased Jesuits as 'saints' (santos). ${ }^{372} \mathrm{He}$ expresses similar sentiments in discussing the life of Francis Borgia: "I understood that it mattered to the world to represent his admirable and heroic virtues, and the unintentional glory that would follow from many imitating his life and using his examples." ${ }^{373}$ In sum, Ribadeneyra's accounts of holy men and women sought to integrate the pious actions of Jesuits within early modern Catholicism and provided models of confession-appropriate conduct. Ribadeneyra not only gave examples, but also a comprehensive model for acquiring saintly conduct, akin to a behavioural manual. ${ }^{374}$

While the use of saints as exemplars affected Catholics broadly, it also encouraged individual devotion. For example in his Confessions, Ribadeneyra was remorseful about his "most serious fault [of] not trying to imitate the examples of the

\footnotetext{
${ }^{371}$ Pedro de Ribadeneyra,"To Gıl González Dávıla, 20 April 1591," in Ribadeneyra, Confessiones, 2: 121-22 "si se miran las cosas del P[adr]e Laynez con atención y ponderación, se hallarán tan admirables, como las de los otros santos de la Coma, y por ventura más imitables, [a list of Laínez'svirtues and deeds] y por sola ella para imprimirse su vida."

${ }^{372}$ Fatás, 14-15. The word santo derives from Roman law and its conception of sacer (which became sanctus then santo), a person set apart from society who can be killed by anyone but not in Roman relıgıous rituals.

${ }^{373}$ Pedro de Ribadeneyra, "To Juan de Borja, Acalá, 6 May 1589," in Rubadeneyra, Confessiones, 2:111-12. "Entendiendo yo lo que importaba al mundo representarle sus admirables y heroycas virtudes, y la gloria accidental que se le seguiría de que muchos la imitasen y se aprovechasen de sus exemplos"

${ }^{374}$ Teófano Egido explores John of the Cross in seventeenth-century haglographies becomıng incorporated into the practice of serving as a model for saintly conduct. Egido, 66-78
} 
saints whose lives I write, and to draw into my soul (by your grace and with the intercession of the saints) a perfect portrait of their admirable virtues." 375 He described his devotion in language similar to producing a visual representation of the saints. The reader of the Flos sanctorum would have had the opportunity to observe saintly virtue through reading, visual representations in art, or through the dramatization of saints' lives. ${ }^{376}$ In his Confessions, Ribadeneyra related the emotional experience of these saints' lives, "since all of the saints' lives that I have written caused this effect [emotionally overwhelmed] in me, but much more will it be caused by the lives of our blessed father Ignatius and of our fathers [Diego] Laínez and Francis Borgia., ${ }^{377}$ While Ribadeneyra's saintly acumen was lacking, the leaders of the early Society exuded sanctity, which other Jesuits came to know and then implement into their own lives:

As I met them and very much tried, they were my friendly and most loving Fathers [Ignatius, Laínez, and Borgia]. I am so certain and faithful a witness of their holy lives and bound by many reasons to imitate their lives, but I never would have written lives for the others, when I compare my life so unlike theirs. Others have taken advantage of what I have written, and that they irrigate their fields with the examples of these holy men [santos varones], while I remain as land parched and burnt bearing no fruit. I fear, I shake, and I tremble that you have to punish me for it, and that the same holy Fathers do not recognise their son. ${ }^{378}$

${ }^{375}$ Pedro de Ribadeneyra, "Confessiones," in Ribadeneyra, Confessiones, 1:85. "Pero en lo que más me remuerde la conciencia, y conozco más graue culpa es en no auer procurado ymitar los exemplos de los sanctos cuyas vidas he escrito, y sacar en my alma (con vuestra gracia e intercesion de los sanctos) vn perfecto retrato de sus admirables virtudes"

${ }^{376}$ Bangert, History of the Society, 59-60, 72-76; Boeck1, 979-95; Chipps Smith, 29-55. On Jesuit theatre, Bruna Filippi, "The Orator's Performance: Gesture, Word, and Image in Theatre at the Collegio Romano," in Jesuits II, 512-29. On Golden Age Spanish preaching and its connection with theatre, please see: Hilary Dansey Smith, Preaching in the Spanish Golden Age (Oxford: Oxford University Press, 1978), $5-28$.

${ }^{377}$ Ribadeneyra, "Confessiones," 1:85. "y puesto caso que qualquiera de las vidas de los santos que he escrito causa este affecto en my, pero mucho mayor le causan las de nuestro beato Padre Ignacio y las de los Padres Laynez y Francisco de Borja."

${ }^{378}$ Ibid. 1:85-86. "Porque como los conocí y traté tanto, y fueron mis cordiales y amantíssimos Padres, y soy tan cierto y fiel testigo de su sancta vida, y obligado por tantos títulos a ymitarlas aunque nunca las huuiera escrito para los otros, quando considero la mía tan desemejante de la suya, y que otros se aprobechan de lo que yo he escrito, y que riegan sus campos con los exemplos destos sanctos varones, y yo 
Ribadeneyra promulgated a model for readıng saints' lives that was imperfect, apparent in the admittance of his fallures Ribadeneyra's Confessions was not meant for broad crrculation, but was a written work of individual penance emulatıng Augustıne's autobiography of the same name In his printed lives, however, Ribadeneyra encouraged a tradition of observational emulation within his sacred biographies for contemporary Catholic culture Imitation acquired through the senses and purported by Ribadeneyra was based on the recognition that God has sanctified the actions of contemporaries here and now In turn, texts transmitted this piety with contemporary models of disciplined behavior through a readıly perceptıble repertorre of santly actıon, such as preaching, confession, and conversion ${ }^{379}$

\section{Catholicism and Saintly Imitation}

Saints provided a template from which Christian virtue could be moulded and formed In the process of confession-building, Catholics drew upon late-medieval practices, while at the same time negotiatıng the ecclesiastical reforms of Trent In fact, Jesuits accommodated Roman rituals to local practices For example, every Jesuit student of theology "should have the [decrees and canons of the] Counc1l of Trent and a volume of the Bible and should be familiar with these texts" ${ }^{380}$ Yet when preaching and delivering sermons,

they should strive for the edification of the people, which differs from the scholastic method, they should seek to learn the vernacular language well, to be prepared and have on hand the most useful things for the ministry, and to

\footnotetext{
me quedo como tierra seca y requemada sin fructo, temo, tremo y tiemblo que me aueys vos de castigar por ello, y que los mismos sanctos Padres no me conozcan por hijo "

${ }^{379}$ Palomo "Corregir letras," 60-69, idem, "Disciplina cristiana," 127-36

380 "Ratıo", 377 "Tridentınum Concilum omnes theologi habeant, et Bibliorum volumen, quorum lectıo sit ıllıs famılıarıs"
} 
have available all the suitable means to perform this task better and for the increased fruitfulness of souls. ${ }^{381}$

According to Tridentine doctrine, saints were not only intercessors but they served as models for the ideal Christian life and conduct. ${ }^{382}$ The desire to emulate saints again manifested itself in the naming of a child at baptism. If a child received a saint's name, it would prompt that child to model their life on their namesake. ${ }^{383}$

This tendency remained scattered throughout Tridentine liturgical texts such as the Breviary. In an oration to St Francis in the Breviary, the text correlated pious conduct with salvation: "as a result of imitating [Francis], may we come to despise earthly things and always rejoice in the sharing of his heavenly gifts." 384 The prayer to Thomas implied attaining perfection through replicating his saintly life. ${ }^{385}$ Finally, one of the readings for Augustine depicted his foundation of a religious community of godly men living and worshipping together that sought to recreate the apostolic way of life. ${ }^{386}$

The correlation between saints and Jesuit religious life also drew upon latemedieval precedents. In Thomas à Kempis's Imitation of Christ, saints were meant to be

\footnotetext{
${ }^{381}$ Ignatius, Constitutiones, IV, viii, [120]. "Assímesmo se exercitarán en el predicar y leer en modo conueniente para la edifcación del pueblo, que es diverso del scholastico, procurando tomar bien la lengua, y tener uistas y a la mano las cosas más útiles para esta officio, y ayudarse de todos medios conuenientes para majorhazerle y con más fruto de las animas." Cf. Constitutions, 201.

${ }^{382}$ Canons and Decrees, 216. "through the saints the miracles of God and salutary examples are set before the eyes of the faithful, so that they...may fashion their own life and conduct in imitation of the saints and be moved to adore and love God and cultivate piety"

${ }^{383}$ Catechism, 194. "this similarity of name [to a saint] will stimulate to the imitation of [the saint's] virtues and the attainment of his holiness; and we should hope and pray that he who is the model of our imitation, may also, by his advocacy, become the guardian of our safety and salvation." The Catechism has numerous mentions of people and saints as 'models of imitation', for instance, Catechism, 390: "We also honour our parents by the imitation of their good example: to study the life of another, as a model for imitation is the highest mark of esteem."

${ }^{384}$ Breviarium, 902. "ex eius imitatione terrena despicere, et coelestium donorum semper participatione gaudere."

${ }^{385}$ Breviarium, 750-51. "Deus, qui Ecclesiam tuam beati Thomae Confessoris tui mira eruditione clarificas, et sancta operatione foecundas...et quae docuit, intellectu conspicere, et quae egit, imitatione complere."

${ }^{386}$ Breviarum, 871. "Quo tempore familiam instituit religiosorum, quibuscum victu communi eodemque cultu utens, eos ad apostolicae vitae doctrinaeque disciplinam diligentissime erudiebat."
} 
a constant fixture in the lives of lay and religious persons alike. It was the only book Jesuits were allowed to own. ${ }^{387}$ For example, on feast days "good spiritual exercises should be renewed, and the prayers of the Saints implored more fervently than ever., ${ }^{388}$ Kempis implored Christians to regard saints as persons in possession of an imitable sanctity modelled on Christ's life. Christians must "[c]onsider the glowing example of the Holy Fathers, in whom shone true religion and perfection...How countless and constant were the trials endured by Apostles, Martyrs, Confessors, Virgins, and all those others who strove to follow in the footsteps of Christ. ${ }^{389}$ Kempis's spiritual exercises taught Christians how to contemplate the lives of saints and provided instruction in the implementation of saintly virtue in everyday life.

While a hierarchy of saints existed, a lesser saint's contribution to Christian life was not refuted as "[a]nyone, therefore, who disparages one of the least of My Saints, in no way adds to the glory of a greater by so doing, for small and great alike are $\mathrm{My}$ creation. ${ }^{390}$ Saints were especially helpful in the formation of conduct for religious men and women: "[t]hey were given for an example to all Religious and they should encourage us to advance in holiness." ${ }^{391}$ Kempis, moreover, bemoaned the spiritual laxness of his time, while celebrating the formation of new religious orders to increase devotion through respecting a Superior's authority, following the order's rule, and fervent

${ }^{387}$ O'Malley, First, 264-66; Regulae Societatis Iesu, 258. "Thomas de Kempis de imitatione Christi, et aliquot ex eiusde[m] auctoris opusculus."

${ }^{388}$ Thomas Kempis, The Imitation of Christ, trans. Leo Sherley-Price (Harmondsworth: Penguin, 1956), 49 .

${ }^{389}$ Ibid. 45.

${ }^{390}$ Ibid. 175 .

${ }^{391}$ Ibid. 46. 
prayer. $^{392}$ The initial recruits of an order as well as its founder according to Kempis were to be "holy and most perfect men, who fought valiantly, and trampled the world under their feet."393 Kempis's call for spiritual renewal resonated with the early Jesuits especially Ignatius.

\section{The Society of Jesus and Saintly Imitation}

Amongst the texts written for the nascent society by its founder Ignatius of Loyola were directives for devotion to saints and the use of hagiographies within Jesuit spiritual life. In the Society's spiritual manual, the Spırttual Exercises, Ignatius suggested that retreatants read the Imitation of Christ, the Gospels, or the lives of saints for spiritual edification. ${ }^{394}$ In that work's additional material, Ignatius incorporated pieces from saints' lives into his list of Christ's mysteries. ${ }^{395}$ Elsewhere in the Exercises, he quoted from the Life of Saint Bernard from an earlier Flos sanctorum. ${ }^{396}$ The Autobıography, meanwhle, also outlined the important role hagiography had in Ignatius's religious transformation. Ignatius did not write this work but recited it from memory to a scribe, Gonçalves, who collected and assembled Ignatius's thoughts. During Ignatius's convalescence from his battle injuries, there were no "false and worldly books that were known as tales of chivalry" present for Ignatius to read. Instead, his attendants provided him two books:

\footnotetext{
${ }^{392}$ Ibıd 46-47. "How deep was the fervour of all Religious at the foundation of their Order' How great was therr devotion in prayer, and their zeal for virtue! How strict was their observance of the Rule' What respect and obedience to the direction of a Superior flourished in those days "'

${ }^{393}$ Ibld 47

${ }^{394}$ Ignatıus, Exercitıa Sptrttualıa, [100] "Para la segunda semana, y así para adelante, mucho aprouecha el leer algunos ratos en los libros De ymitacione Xpıo de los Euangelıos y de vidas de sanctos" See also Leturia, 2 273-82

395 Ibıd [310] "DE LA 12 aPARICIÓN: Aparesció a Joseph ab Arımatía, como píamente se medita y se lee en la vida de los sanctos"

${ }^{396}$ Ibıd [351] "y sı vee que es su deuıdoseıuıcio, o a lo menos no contra, deuehazer per diametrum contra la tal tentación, iustaBernardumeıdemrespondetem Necpropter te incepı, necpropter te finıam "The underlined text is the quotation from the life of Saint Bernard, which featured in an earlier Flos sanctorum Ibıd [351 n 1] "Hanc sententıam legere potuit Ignatius in opere Flos sanctorum In Vida de San Bernarndo hoc modo exprimitur "Ni por ti lo commence, ni por th lo dexare" "
} 


\section{Ludolph of Saxony's Life of Christ and a collection of saints' lives in Cast1lian ${ }^{397}$ After}

reading these works, Ignatius decided to implement the conduct of saints into his life in particular modeling himself on Domınic and Francis ${ }^{398}$ When Ignatius journeyed towards Manresa, he examined his conscience by meditating on the Life of Saint Andrew As a result, Ignatıus adopted Andrew's ascetıcısm ${ }^{399}$ While Ignatıus often used saints' lives to inform his conduct, his mystical encounters with saints asserted their continued importance as intercessors in everyday religious life ${ }^{400}$

997 Ignatıus, “Acta Patris Ignatı,', [6] "Y porque era muy dado a leer libros mundanos y falsos, que suelan llamar de Caballerias, sintiendose bueno, pidio que le diesen algunos dellos para pasar el tıempo, mas en aquella casa no se hallo ninguno de los que el solıa leer, y ası le dieron un Vita Christı y un libro de la vida de los Santos en romance "Whıle Ignatıus's autobıography does not specify the name of the collection of saints' lives, Hieronymo Nadal in 1561 suggested that Ignatius had read a Flos sanctorum Jeronımo Nadal, "Adhortatıones Complutenses 1561," in Fontes narrative de S Ignatio de Loyola et de Societatls Iesu Inituls, ed Candido de Dalmases (Rome Monumenta Hıstorica Societatıs Iesu, 1951), 2 [4] MHSI 73 "Incomıncio adunque dalhora a star meglı $1 \mathrm{~N}$ Ignatıo, et essendo gia in convales[c]entia, domando un libro de cavallerie per legger, et non vi si trovo in casa nesun libro tale, nel quali si soleva occupar, solamente sı trovo un Vita Chrıstı del Cartusiano et un libro dı Vite dı Santı che sı chiama Flos Sanctorum in vuolgar spagnolo"

${ }^{398}$ Ignatıus, "Acta Patris Ignatı1," [7] "Porque, leyendo la vida de nuestro Señor y de los santos, se paraba a pensar, razonando consigo ¿que seria, si yo hiciese esto que hizo $S$ Francisco, y esto que hizo $S$ Domıngo? Y ası discurria por muchas cosas que hallaba buenas, proponiendose siempre a si mismo cosas dıficultosas y graves, las qualesquando proponıa, le parecia hallar en sı facilidad de ponerlas en obra Mas todo su discurso era decir consigo S Domingo hizo esto, pues yo lo tengo de hacer S Francisco hizo esto, pues yo lo tengo de hacer "Pedro de Leturia also compares Ignatıus's use of Francis and Dominic as exemplars with Nadal's belief that Onuphrius was another, see Leturia, 1 100-11 This episode did not feature within Ribadeneyra's biography on Ignatıus In fact, the original Latın edition made no mention of the Flos sanctorum Ribadeneyra, Vita Ignatıl, 86-7

${ }^{399}$ Ibıd [24] "Y ası le vino al pensamıento la hıstorıa de un santo, el qual, para alcançar de Dios una cosa que muchos deseaba, estuvo sin comer muchos dias hasta que la alcanço" Thıs passage comes from "Opus Flos Sanctorum, quod exstat in archivo Loyolaeo narrat hoc de Sto Andrea Apostolo" Ibid [24 n 2] Cf Ribadeneyra, Vita Ignatul, 119

${ }^{400}$ Ignatıus, "Ephemeris," 98 "De ay a vn rato, pensando por donde comencarıa y acordandome que a todos Sanctos, encommendandome para que rogasen a nuestra Señora y a su hijo porque ellos me fuesen intercesores con la Sanctissima Trinıdad, con mucha deuociony intension me cubrı de lagrimas, y ası me fuy para confirmar las oblıgaciones pasadas, interloquendo muchas cosas, rogando y poniendo por intercesores a los angeles, sanctos padres, apostoles y discipulos, y a todos los sanctos, etc para nuestra Señora y su Hijo hize la confirmacion vltımada a la Sanctıssıma Trınidad delante de toda su corte celestıal, dando gracias con mucho intenso afecto, prımero a las personas dıuınas, despues a nuestra Señora y a su $\mathrm{H}_{1 j o}$, despues por los angeles, sanctos padres, apostoles, discipulos, a todos sanctos y santas y a todas personas que para esto me avian ayudado" 
Whether through saints or other Jesuits, the imitation of virtue and good conduct was an important facet of Jesuit spiritual lıfe. ${ }^{401}$ The Jesuit Constıtutıons frequently discussed this regulation of behaviour For example, older Jesults established a model of good conduct for the order's younger members "because to move forward in virtue is assisted greatly by the good example of the older members that encourages the others to imitate them. ${ }^{, 402}$ In Canisius's Catechism, a brief discussion encouraged the imitation of saints and celebration of their feasts ${ }^{403}$ Observing examples of virtue complemented other components of life in the Society best seen in the Jesuit engagement with religious art and architecture for spiritual edification. ${ }^{404}$ This communication of exemplary virtue also occurred at Mass, a social institution that experienced standardization after Trent. ${ }^{405}$ During Mass, the priest would read from saints' lives to expand upon the lessons from his sermon or to celebrate a saint's feast day. ${ }^{406}$ Wh1le the saints provided superlative examples of Catholic virtue, the priest was a source of idealised confessional conduct:

${ }^{401}$ Aragués Aldaz, Deus concionator, 25-30

${ }^{402}$ Ignatius, Constitutiones Socletatis Iesu, III, 1, [91] "Porque para passar adelante en las virtudes ayuda mucho el buen exemplo de los más antıguos que anıme a los otros su imitación "Cf Constitutions, 161.

${ }^{403}$ An entire section of the Catechism focuses on "In what way do we worship and invoke saints before God?", Canısius, 81-101 The discussion on the imitation of sants appears in idem, 100-1 "Isidorvs libro primo de Ecclesiastıcis officijs, capite trigesimoquatro Festiuitates Apostoloru[m], seu in honore martyrum solennitates, antıqui patres invenerationis mysterio celebran sanxerunt, vel ad excitandam ımitationem, vel vt mentis eorum consocremur, atq[ue] orationıbus adıuuemur ita tamen, vt nullı martyrm, sed ipsi Deo martyrum offeramus, quanıus in memorijs martyru[m] constituamus altarı Quis enim antistitu[m], in locis sanctorum corporu[m]] assistens altarı, alıquando dixit, Offerımus tibı Petre, aut Paule, aut Cypriane? Sed quod offertur, offertur Deo, qui martyres coronault, apud memorias eorum, quos coronauit, quo ex ipsorum locorum amore maır affectus exurgat ad auge[n]dam charitatem, \& in illıs, quos imitarı possumus, \& in illo quo adiuuante possimus Colimus ergo martyres eo cultu dilectionis \& societatis, quo \& in hac vita coluntur sanctı homines Dei, quorum cor ad talem pro Euangelica veritate passionem paratum esse sentımus Sed illos tanto deuotıus, qua[n]to securıus post certamina omnia superata, quanto etiam fidentiore laude prae dicamus iam in illa vita feliciores victores, quam in ista adhuc vsque pugnantes"

${ }^{404}$ Balley, Renalssance and Baroque, 5-22, David M Kowal, "Innovation and Assımılation The Jesuit Contribution to Architectural Development in Portuguese India," in Jesuits, 480-504

${ }^{405}$ To describe and to conceptualise the mass as a social institution derives from John Bossy, "The Mass as a Social Institution, 1200-1700," Past and Present 100, 1 (1983) 29-61

${ }^{406}$ Smith, Preaching, 29-59 
those [men] that should be ordained are to be instructed in reciting the Mass, not only with the utmost understanding and interior devotion, but also with a good exterior manner, for the edification of those who hear the Mass. All members of the Society should use as much as possible the same ceremonies, conforming to the extent that the diversity of regions permits, to the Roman usage as the most universal and particularly in its embrace by the Apostolic See. $^{407}$

Similarly, while the sermon's content was integral to the religious experience, the preacher must also exhibit fitting conduct in the delivery of the sermon.

Preacher and sermon alike instructed the audience, especially in the Jesuit colleges. $^{408}$ In this letter, Ignatius explained to Antonio Brandano that preaching contributed to the development of a good Christian life. Ignatius compared the fervent preaching of the Society and its bountiful harvest with the scholastics' comparative famine due to the insufficient time spent providing moral improvement. Mass was also a site for mystic visions. Ignatius recounts that in the midpoint of the service, "[i]n these times I felt the visitations in an imprecise manner, they fixated...at times, on the saints or specific ones, there were many tears." ${ }^{409}$ Mass was not only an ideal venue to disseminate these saintly virtues through the senses for the purposes of spiritual edification, but a site for instituting a Catholic 1dentity amongst members of the congregation. ${ }^{410}$

Corresponding with Mass's spiritual offerings, Ignatius encouraged the communication of sanctified conduct through works and writings. The external conduct

\footnotetext{
${ }^{407}$ Ignatius, Consttutiones Societatis Iesu, IV, vi11, [119-20]. "se ayan de ordenar, se instruyan en el dezır la missa, ultra de la intellıgencia y deuoción interna, con buen modo exterıor, para la edıficación de los que oyen, usando todos los de la Compañía unas mismas ceremonias en quanto se puede, conformándose en ellas, quanto la variedad de las regıones suffriere, al uso romano, como a más unıuersal, y specialmenteabraçado por la sede apostólıca "I used Ganss's translation here. Constıtutıons, 201

${ }^{408}$ Ignatius of Loyola, "To Antonio Brandano, Rome, 1 June 1551," in Ignatius of Loyola, Epistolae et instructıones (Madrid Gabriel López del Horno, 1905), 3. 510 MHSI 28 "A estos exercicios se puede ayuntar el del predicar en los collegıos; porque como después de la buena vida, vna de las partes que más ayudan al próximo (á lo que muy specialmente se ordena la Compañía) es la del predicar, parecía á [Ignacio] que no poco fruto se sacarıa si los scolares se exercitassen en predıcar"

${ }_{409}$ Ignatıus, "Ephemeris," 119-20. "En estos tıempos sentía las visitaciones indiferenter, termınándose. quando en los sanctosavn particularmente, con muchas lágrımas"

${ }^{410}$ Aragués Aldaz, "Deus concionator," 69-77, 86-92
} 
of Jesuits augmented by words was a great force for instituting social discipline. It was important for Jesuits "to be a good example of Christian virtue and integrity, trying to edify through good deeds more than words amongst those whom you have dealings with." ${ }^{, 411}$ Ignatius, however, placed limits on the comparisons Jesuits might make between themselves and saints. It would be an error to say things such as "He knows more than St Augustine', 'He is another St Francis or greater', or 'He is another St Paul in his virtue or sanctity’..912 He also chastised Juan de Tejeda a Franciscan friar and one of Borgia's initial spiritual directorsfor some of Tejeda's assertions. When Tejeda asserted his superiority to Francis of Assisi, Ignatius considered Tejeda irreverent for not only contrasting himself with Francis but also for comparing living persons with saints. ${ }^{413}$ In Ignatius's refutation of Tejeda and other reformers, Ignatius drew on the saintly precedent of the Desert Fathers featured in John Cassian's Conferences. ${ }^{414}$ Tejeda and the reformers had desired to increase time spent in prayer, but Ignatius refuted their claims with the precedent of Desert Fathers: their daily hour of prayer and its organisation. ${ }^{415}$

\footnotetext{
${ }^{411}$ Ignatius, Constitutiones Societatts Iesu, VII, 1v, [182] "ser le buen exemplo de toda honestidad y uirtudChristiana, procurando no menos sino más edıficar con las buenas obras que con las palabras los con quien se trata." Cf Constitutions, 281.

${ }^{412}$ Ignatius, Exercitta Spirttualia, [364] "Debemos guarder en hazer comparaciones de los que somoviuos a los bienauenturados passados, que no poco se hierra en esto, es a saber, en dezır: éste sabe más que santAugustín, es otro o más que san Francisco, es otro san Pablo en bondad, sanctıdad"

${ }^{413}$ Ignatıus of Loyola, "Judicium de quibusdam opınombus, quae falso revelationes credebantur," 1n Eplstolae et instructiones (Madrid Gabriel López del Horno, 1911), 12 647. MHSI 42 "En la qual primeramente parece ay desacato en comparer los viuos y mortals con los sanctos, y tal en especial como san Francisco"

${ }^{414}$ Ibid. 12: 651-52 "Veyse por exemplo de los sanctos Padres anacoretas que comúnmente tení[an] oraciones que no llegauan á vna hora, como se vey en Cassiano que t[antos] psalmosdezían de vna vez, etc , como en el officio público y horas ecclesiástıcas se pratıca "Cassian was also widely-read in Latın in early modern Madrıd and in the order Bernabé, 1·235, Leturıa, $2282-96$

415 By 1549, the date of this letter, both Nadal and Juan-Alfonso Polanco assisted Ignatius in legislatıng and running the Society This conflıct between Ignatıus and the reformers (Tejeda, Andrés de Oviedo, and Françoıs Onfroy), who ran in the same circles as Borgia are indıcatıve of the constant flux in the early decades of the Society The order had to deal with parties who wished to indulge in devotional excesses, such as potentially fatal fasting and hour upon hour spent in prayer The circle around Ignatius opted for a middle way, avoıding the harsh ascetic practices that left Ignatıus with permanent alments See also: Leturia, 2 193-217
} 
Ignatius, while favouring a tangible Society dedicated to works, created a simultaneous 'silent society', where the basis of the order's identity, community, and social discıpline were texts. ${ }^{416}$ Written instructions encouraged and ordered a Society that propounded ideals of orthodox conduct to its brethren. Letters in both Latin and the vernacular from the Jesuit provinces circulated widely to assist in the spiritual edıfication of other members of the Society. ${ }^{417}$ The provincial was to send letters quarter-annually to both the Jesuit institutions within his province as well as to Rome. These letters transmitted recent occurrences in the province, such as the number of conversions and the building of new institutions. They also provided living exemplars through the accounts of other Jesuit deeds akin to hagiographies. Embedded within Ignatius's use of saints as exemplars was the assertion of a distinct Jesuit identity as missionarıes, preachers, and otherwise saintly men. These ideals received support through life-writing, whether saints' lives or letters from missionaries.

Jesuits used saintly precedent to depict not only the orthodoxy of the Society, but also its place within Catholic religious life. Polanco positioned the Jesuit order's identity within the broader realm of Catholic devotion:

some saints have notable qualities that are wanting in others, and the same is true for religious orders, thus [Ignatius] wanted the Company to have a quality, which would be equal to that of any of the other orders, even if they

\footnotetext{
${ }^{416}$ Bouza, Communication, 32

${ }^{417}$ Friedrich, 6-20, O’Malley, First, 63, Palomo, "Corregır letras," 67-79; Ignatius, Constıtutıones
} Soctetatıs Iesu, VIII, 1, [109-110] "Para que las nueuas de la Compañía puedan communicarse a todos, seguirásse la forma siguiente Los que son debaxo de un prouıncial de diuersas casas o collegios, escriuan cada principıo de quarto meses una letra que contenga solamente las cosas de edificación en la lengua vulgar de la prouincia, y otra en latín del mesmo tenor, y embíen la una y la otra duplicada al prouncial, para que embíe la una copıa latına y uulgar al general con otra suya, donde diga lo que ay notable o de edificiación que no tocan los partıculars, y la otra haga copıer tantas vezes, que baste para dar notıcia a los otros de su prouıncia En caso que se perdiesse mucho tiempo en embiar al prouncial estas letras, pueden los locales y rectores embiar al general derechamente sus cartas latına y vulgar, y la copia al prouncial También el prouincial, quando le pareciesse, puede cometer a algunos de los locales que aursen a los demás de su prouincia, embrandoles copras de la que escriuen al prouncial" 
have other qualities that we cannot have, although we may try to equal them in some things, such as in poverty And our Reverend Father [Ignatius] wished our quality to be obedience ${ }^{418}$

The virtues of saints were equated with those of religious orders as specific saints embody and exude a specific desırable quality into believeıs Simılarly, religıous orders have specific traits that they wish to share with others The discussion of obedience stressed the Jesuits' submission to papal authority ${ }^{419}$ While much separated Catholics from other confessions, a confessional identity amongst Catholics manifested in their continued devotion to saints, the ongoing importance of religious orders, and the doctrine of the primacy of the pope Jesuits formed an identıty built upon a religious community modeled on saints

Saintly practices were incorporated into the spiritual behaviour as well as the everyday life of Jesuits In Nadal's Instructions, he provided a catalogue of appropriate books to be held at the colleges and provided certain guidelines for texts that should be read For example, Jesuits used the Martyrology at vespers for reading or preaching ${ }^{420}$ Amongst the books recommended by Nadal are the collection of saints' lives by Surıus and Lippomano, the Imitatıon of Christ, Ignatıus's letter on obedience, the Society's quarterly letters, the works of the Church fathers, in addition to the letters and the life of

${ }^{418}$ Ignatius, "To Antonı Brandano," 3509 "desseaua que assı como en vnos santos ay preeminentias que no hay en otros, y en vnareligion lo mismo respeto de otra, que assidesseaua en la Compañia huulessevnapreexcellentia, con que se igualasse a qualquiera de las otras congregaciones, teniendo ellas otras que la nuestra no puede tener, aunque pueda en alguna ygualarse, como en la pobreza, y querı nuestro Rdo Padre que esta nuestra fuesse la obediencia"

${ }^{419} \mathrm{Ibid}$ "y paia esta teniamos mas obligacion, por el voto de mas que tienen los Padres, de obediencia al summnopontıfice, y porque no pueden scusarse para no cumplır alguna obedientıa"

${ }^{420}$ Hieronymo Nadal, "Instructiones (1562)," in Epistolae Hieronym Nadal (Madrid Gabriel Lopez del Horno, 1905), 4448 MHSI 27 "Vesperı, absoluta lectione vel praedictione, legatur martyrologium vulgarıter" 
Catherine of Siena ${ }^{421}$ The Socıety's thırd Superıor-General Francis Borgia suggested that on the feast day of a saint the religious person must "read [the saint's] life and see to the repetition of that virtue, and endeavour to imitate their life, by doing some acts of this virtue that day" 422 These tendencies permeated the Society's educational institutions For example, professors encouraged students to compose poems based on the events from a saint's life ${ }^{423}$ In the rules for students at Jesuit colleges who did not belong to the order, these students must revere the saints sincerely as well as maintaining equal interest in learnıng, virtue, and integrity in their lives ${ }^{424}$ In the Jesuit colleges, social discipline centered on models of saintly behaviour

A Jesuit contemporary of Ribadeneyra, Alonso Rodríguez, discussed the saintly discipline expected of the devout Rodríguez wrote his Practice of Christian Perfection for a Jesuit audience based on his long carrer as a spiritual advisor and as a master of novices The work's audience expanded to include devout readers not in the Society of Jesus In the Practıce of Christıan Perfectıon, Rodriguez suggested

Mother Church puts before us examples of the saints and celebrates their feasts If you wish to take examples that come nearer home, look to your brethren born of the same mother from the same religious order and society Fix your eyes on Father Ignatius, on a Francis Xavier and Francis Borgia, on

${ }^{421}$ Ibıd 4 448-49 "Historia sanctorum, Lipomanı vel Surı cum annotationıbus ad margınem Epıstolae alıquae S Hieronymı, nonnullae etıam S Gregorı, S Ambrosı et S Augustını Opera alıqua deuota B Augustını, et sermones alıquı eiusdem, et deuota opera S Bernardı Nonnulla deuota opera S Bonauenturae Gerson, de imitatione Christı, vulgarı etıam lingua, opera etiam alıqua deuota elusdem Epistolae S Catharinae Senensis et vita eius Omnes has epistolas et opera prouincialis seligi curabit per ıdoneum alıquem, ıpse vero iudicium etıam suum illiu s selection adhibebit an recte habeat Epistola Patrıs Ignatı de obedientıa, quam misıt ad collegıum conımbricense, legı poterıt, quum leguntur regulae "

${ }^{422}$ Francisco de Borja, Tratados Espirituales (Barcelona J Flos, 1964), 480 "Leer su vida y ver en que virtud se señalo mas, y procurer imitarle, hacienda algunos actos de aquella virtud entre dia"

${ }_{423}$ "Ratıo", 428 "Affigantur carmina scholae parıetıbus alternis fere mensıbus ad aliqeum celebriorem diem exornandum, vel magistratus promulgandos, vel alıa quapiam occasione, selectıssima quaeque a discipulis descripta quales narrations, ut reı gestae ab alıquot divorum "

424"Ratıo", 447 "Sincerum anımum purumque conservare, ac divınıs legıbus summa dılıgentıa obtemperare nitantur ceterisque sanctıs persaepe atque ex anımo se commendant In rebus denıque atque actionıbus ommibus ita se gerant, ut facile quivis intelligat, eos non minus virtutum vitaeque integritatis esse, quam literarum doctrinaeque studiosos" 
an Edmund Campion, and similar others that you know. Try to imitate them. $^{425}$

The role of the religious community was to facilitate this imitation of saintly virtue, whether within the tangible society at colleges, novitiates, professed houses, or the silent society dispersed through books and letters read. In describing how Jesuits should behave, Rodriguez used a common metaphor for reading and excerpting based on a saint's recommendation:

The blessed saint Antony the Great advised the same and he said, that the religious travel, as good bees, picking the little flowers of all to make their honey. From one modesty, from another silence, from another obedience, and from another indifference, as well as resignation: in each one we have that the saint radiates the most for us to imitate. So we read what the person did and how they became such a great saint. ${ }^{426}$

The pursuit of saintly conduct is not contingent on location, but rather on the observation of virtue through reading a saint's life or observing holy men and women. ${ }^{427}$

For Rodríguez, saints' lives made religious virtue accessible to readers. Whether derived from the Gospels or later sacred biographies, these texts provided case studies in

${ }^{425}$ Rodríguez, 142 "la Iglesıa nuestra madre nos pone dela[n]te el exemplo de los santos, 1 celebra fiesta dellos. I si lo queress tomar de mas cerca, mirad los exemplos de vuestros hermanos, nacidos de un mısmo vientre, de una misma relıgıon, $1 \mathrm{Co}[\mathrm{m}]$ pañıa; poned los ojos en un padre Ignacıo, en un Francisco Xavier, 1 Francisco de Borja, en un Edmu[n]do Campiano, 1 enotros semejantes que sabeis Procurad de imitarlos"

${ }^{426}$ Ibıd 1 70-1 "Pues a esto venımos a la relıgion, I poco nos aprovechará estar en ella, sı no hazemos aquello a q[ue] venımos Porq[ue] no haze santos el lugar, si no la vida religıosa, 1 perfecta Dize esto mu bien S[an] Agustın, en un sermon que haze a los religosos, q[ue] moravan en el desierto Ecce in soltudine sumus in heremo sumus, locus tamen no factt sanctos, sed operatıo bona locum sanctificabit \& nos Vers aqui hermanos mios estamos en la soledad, ya dexamos el mundo, 1 estamos en la religion. Pero el lugar no haze santos a sus moradores, sı no las obras buenas, la vida relıgıosa, essa hara santo el lugar, 1 a nosotros tanbien"

${ }^{427}$ Ibıd 160 "Lo mısmo aconsejava el bienaventurado san Antonıo abad, I dezıa, que el religioso a de andar, como buena aveja, cogiendo las florecitas de todos, para hazer su miel, de uno la modestra, de otro el silencio, de otro la paciencia, de otro la obediencia, 1 de otro la indiferencia, 1 resignacion' en cada uno avemos de mirar aquello, en que mas resplandece, para imitarlo Assi leemos, que lo hazıe el, 1 con esso vino a ser tan grande santo" 
particular virtues ${ }^{428}$ For example, Rodriguez used the Life of Saints Pachomius and Palemon to depict the faultiness of pride ${ }^{429}$ Rodriguez also advocated for the imitation of saints to obtain humılity ${ }^{430}$ While saints were historical figures worthy of emulation, their sanctity was unobtanable and warranted contınued veneration by Catholics, whether lay or religıous Catholic could approach Christıan perfection through recreating the lives of saints in therr quotidian affairs.

\section{Surius, Saints' Lives, and Imitation}

Jesuit directives encouraged the reading of Surius's compilation in their culture of hagiography-based observational emulation. ${ }^{431}$ Both Ribadeneyra and Villegas mention and cite Surius in their respective Flos sanctorum Villegas held Lippomano and Surius in high esteem. For example, Villegas described Lippomano as the the "most learned .most religious, no less eloquent, and erudite," while Surius's saints lives were "very serious, very authentic, and true.", ${ }^{332}$ For Ribadeneyra, Surıus and Lippomano occupied an elevated position amongst hagıgraphıcal writers as revered authorities; Ribadeneyra included them amongst the martyrologies by Bede, Usuard, and Adon as

${ }^{428}$ Ibid 1 385-86 "Hugo de Santo Victor trae vn exemplo de un siervo de Dios, que por revelacion fue amonestado, que dexasse la leccion de estas cosas, 1 leyesse las vidas, 1 martirios de los santos, 1 otras cosas llanas, 1 devotas, con lo cual aprovechó mucho"

${ }^{429}$ Ib1d 2170 "Milagros hazıa aquel mo[n]ge, de quie[n]se escrive en la vida de San Pacomı, 1 Palemon, que andava sobre las brasas, sin quemarse, en pero de aquello mismo se ensobervecio, 1 tenia en poco a los otros, 1 dezia de s1 mismo, este es santo, que anda sobre las brasas sin quemarse, cual de vosotros hara otro tanto? Corrigiole san Palemon " viendo que era sobervia, 1 al fin vino a caer miserablemente, 1 acabar mal Llena está la Escritura, 1 las hıstorias de los santos de semejantes exenplos"

${ }^{430}$ Ibid 2228 "Pues a esta perfeccion de humildad avemos de procurar llegar I no se nos haga esto inpossible, porque con la gracia de Dios, dize san Augustın, no solamente a los Santos, sino al Señor de los Santos podemos imitar sı queremos porque el mismo Señor dize, que aprendamos del "

${ }^{431}$ Nadal, "Instructiones,"4 448-49 "Historia sanctorum, Lipomanı vel Surıl cum annotatıonibus ad marginem "Regulae, 257 Included amongst the books to be read as a supplement to Scripture "Vita sanctorum Aloysı Lipomanı Vitae sanctorum Surı" See also Palomo "Corregir letras," 60-69, tdem, "Disciplina cristiana," 127-36

${ }^{432}$ Villegas, Flos (1588), sig | $3 \mathrm{v}$ "De los autores y lugares que he referido, todos muy graues, muy autentıcos, y verdaderos, recoligieron, y compusieron sus grandes volumines, el dotıssimo Obispo Lippomano, y el relıgıosıssımo, y no menos eloquente y erudito fray Laurencı Surı"” 
well as the Roman Martyrology. ${ }^{433}$ Surius's compilation focused mostly on miracles, but it also promoted saintly imıtatıon of virtues that varied from saint to saint ${ }^{434}$ In Surius's collection, saints based their conduct on Christ's example and through observing religious men and women. They then themselves became objects of imitation

For saints, Christ was the constant paragon to follow. Starting with the apostles and incorporating subsequent generations of holy men and women, Christ established for his followers the religion's doctrine and ideal life. For instance in Surius's work, he argued that Peter and Paul's holiness manifested through the recall and replication of the life of Christ*

I remember you, O Peter, and I am struck dumb. I think about you, O Paul, and I am moved to being overwhelmed with tears. I do not know who will I talk to, or who will I speak with about your notable torments. How many prisons did you sanctify? How many chans did you glorify? How many torments did you endure? How many insults did you tolerate? In what way did you transport Christ? In what manner did you enrich churches with preaching? Deeds are blessed by your speech Your members spattered with blood on account of the Church. You imitated Christ in all things without weakness. Your voice echoes through every land, your word to the ends of the earth ${ }^{435}$

${ }^{433}$ Ribadeneyra, Flos (1599), sig ๆ $5 \mathrm{v}$ "Los Autores que he seguido en escriurr estas vidas, son los mas graues, y de mayor autoridad que ay, y conocidos, y recebidos por tales de toda la Yglesia Catolica, y los Martyrologios, Romano, de Beda, Vsuardo, y Adon Tambien me he ayudado de los piadoss trabajos de Luıs Lipomano, Obıspo de Verona, y del Padre fray Lorenço Surı, monge Cartuxo, varones en vida, doctrına, y zelo de la honra de los Santos, sıgnos de perpetua alabança y recordacion "

${ }^{434}$ Ditchfield, Liturgy, 124

${ }^{435}$ Surius, 6 646 "Meminı tul, Petre, et obstupesco Recordor tul, Paule, et mente emotus opprimor lacrymis Quid enim dicam, aut quid loquar, vestras contemplans afflictiones, nescio. Quot carceres sanctificastıs? Quot catenas decorastis? Quot tormenta subistis? Quot maledicta tolerastıs? Quomodo Christum portastıs? Quomodo praedicatıone Ecclesias laetıficastıs? Sunt benedıcta vestrae linguae instrumenta Sanguine conspersa sunt membra vestra propter Ecclesiam Vos sine defectu imitatı estıs Christum in omnibus In omnem terram exılt vester sonus, et verba vestra in fines orbis terrae "Surius used John Chrysostom's Homily of St Peter On Chrysostom, preaching, and homilies, see Claudio Moreschinı and Enrico Norellı, Early Christıan Greek and Latın Literature A Literary History, trans Matthew J O'Connell, 2 vols (Peabody, MA Hendrıckson Publishers, 2005), 2 149-53 
Other Biblical figures underwent sanctification by duplicatıng the life of Christ According to Surius, Stephen's virtue was his imitation of Christ, not another saint ${ }^{436}$ At the same time, the mendicant founders also saw Christ's life as a path they ought to follow For instance, Dominic wanted to sacrifice his life for the salvation of others, echoing Christ's crucifixion ${ }^{437}$ Francis, meanwhile, taught his followers not to worship him, but to be devoted to Christ According to the life of Francis, the saint imitated Christ's life "Francis also taught his disciples to follow with discrimination, and to follow[prudence], the charioteer of the virtues, not he who praises the flesh, but what Christ taught, whose most holy life Francis closely followed as being the example of perfection "438 In these hagiographies, saints emulated the life of Christ in order to regulate their personal conduct, and as a result achieved salvation for themselves as well as others

Dominic appropriated examples from the lives of sants, such as those he read in Cassian's Conferences ${ }^{439}$ A manual for living a spiritual life through developing the invisible and interior self, the Conferences provided examples of this practice through

\footnotetext{
${ }^{436}$ Surıus, 12 449-50 "Quam praeclara bonorum serıes, quam dulcıs laetıtiae successıo' Ecce enım celebritatem ex celebritate, et gratıam pro giatıa suscipımus Heıı nos excepit convivıo reı um omnum Dominus, hodıe excipıt Domını ımıtator"

${ }^{437}$ Ibıd 8117 "Nec minus paratus erat pro salute proxımorum ponere anımam, Chrıstum in hoc imitarı gestiens" Surius based his account on the Life of Dominic by Dietrich of Apolda, one of several Dominican friars composing the life of Dominic for commemorative and liturgical purposes, such as PetrusFerrand, Constant of Orvieto, and Humbert of Romans See Bert Roest, "Later Medieval Institutional History," in Historiography in the Middle Ages, ed Deborah MauskopfDeliyannis, 277-315 (Brill Leiden and Boston, 2003), 292

${ }^{4,8}$ Surıus, 10135 "Docuit insuper eos discretıonem sequi, ut aurıgam virtutum, non eam quam caro suadet, sed quam edocult Chrıstus, culus sacratıssımam vitam expressum constat esse perfectionıs exemplar"

439 Ibid 8111 "Habitum igitur Canonicae religionıs indutus extrinsecus servus Christ1 Dominıcus, per Deı gratıam novum homınem intrınsecus induit, moxque in Del timore ad totıus sanctitatıs studium conversus, in seipso prius exprimere curavit, quod erat alıos postea docturus Satagens igitur perfectorum imitarı vestıgia, et ad virtutum fastıgıa contendere, novitius Canonicus solicite de antıquis semitis inquirebat, ut sciret quae esset via bona, ut ambularet in ea Unde librum 1llum, qui Collationes Patrum inscribitur, studiose legendum susceptt, deditque operam, ut lecta, intelligentia comprehenderet, affectu sentıret, effectu et re ipsa fortiter exequeretur"
} 
Cassian's interaction and observation of Egyptian monks. Cassian realised that Christian perfection was attained through monastic vocation and discipline. ${ }^{440}$ Right conduct was an ongoing process and invited the participant to emulate sanctity through reading the life of Christ and any of the institutional church's saints. ${ }^{441}$

In turn, the imitators became the imitated. For example, the life of Thomas Aquinas stressed that Thomas read and meditated upon Cassian's Conferences as Dominic had. ${ }^{422}$ Yet Thomas also encouraged emulative behaviour since he was "an example, therefore, given to us...if we want to aspire to perfection. ${ }^{, 443}$ The formation of conduct occured through study of the life of the saint in question, but also through books, since Thomas

frequently read the Conferences with pleasure. Indeed by observation of subtle things his emotions grew gradually warmer, and he was easily able to focus and excite the contemplation of divine things. And in this, he followed St Dominic, who in reading the same book was greatly delighted, and was inspired and moved towards a greater perfection of life. ${ }^{444}$

Imitation continued as long as there were universal and localised exemplars. In the case of Thomas, Christ was the model of sanctity above all others, while Dominic provided a

\footnotetext{
${ }^{440}$ Moreschini and Norelli, 2:433-34.See also, Steven D. Driver, John Cassian and the Reading of Egyptian Monastic Culture (New York and London: Routledge, 2002), especially 45-58, 107-18.

${ }^{441}$ Reading, hearing, and writing were important practices in Augustine's spiritual life. An excellent study that investigates these interconnected processes (especially reading) is: Brian Stock, Augustine the Reader: Meditation, Self-Knowledge, and the Ethics of Interpretation (Cambridge, MA: Harvard University Press, 1996).

${ }^{442}$ Breviarium, 751. "Collationes Patrum assidue pervolutabat; et nullum fuit scriptorum genus, in quo non esset diligentissime versatus." Italics are mine.

${ }^{443}$ Surius 3:76. "Exemplum igitur dedit nobis...si velimus ad perfectionem aspirare."

${ }^{444} \mathrm{Ibid}$. 3:82. "libenter solitus fuerit aliquid in Patrum Collationibus lectitare, ne ex rerum subtilium speculatione affectus eius nonnihil tepesceret, possetque se rursus facilius ad divina contemplanda colligere et erigere. Et in hoc quidem S. Dominicum sectatus est, quem eius libri lectione constat magnopere fuisse delectatum, et ad magnam vitae perfectionem incitatum atque promotum."
} 
more immediate and knowable rendition. A similar connection was evident in the relationship between Bonaventure and Francis, the bond between disciple and founder. ${ }^{445}$

Notably, saints provided exemplars of piety and devotion One description of Dominıc refered to him as an "example of sanctity"or as an "admirable [man that] provoked others by an illustrious example", which "he encouraged by words, and he summoned by example." ${ }^{\$ 46}$ The portrayals of Francis employed suggestive language for the purposes of imitation, for instance

Therefore Francis, the Most Profound Servant and Friend, founder and leader of the Order of Friars Minor, avowed of poverty, the very image of patience, harbınger of truth, the mirror of sanctity, and the model of perfection of all the Gospels, blessed by heavenly grace from the lowest methodically progressed to arrive at the highest ${ }^{447}$

The use of evocative descriptors such as 'pattern', 'mirror of sanctity', 'example of perfection', cast Francis as a template for the Christian life, but also as a model for how this life could be reflected and gazed at. This process of emulation for a saint was methodical and required ongoing contemplation and consideration. Thus, we see that Surius described three related processes of sanctified behaviour First, the individual used Christ's life as a guide to living in a Christian and sanctified manner. Second, saintliness derived from earthly models either through first-hand observation or through reading.

\footnotetext{
${ }^{445}$ Ibıd 7263 "Iam intellıgıs, Pater beatıssıme, quod et per te planıus intelligebas, quis qualısve fuerıt Bonaventura, de quo agımus, culus vita et exemplıs, beatı Franciscı relıgı ıllustrata, et doctrına "

446 Ibid 8 110, 112. "intuentesque praeclaro provocavit exemplo et verbis hortabatur, et exemplıs invitabat Equidem felıcem dixerım electrum Deı Dominıcum, quı tantı pontıficıs et virı Apostolici meruerit societate et amicitia decorarı, a quo dubium non sit, illum sanctitatis exempla et religıonis institutiones hausisse"

${ }^{447}$ Ibıd 10176 "Franciscus 1gitur, Servus et Amıcus Altıssımı, Ordınıs Minorum fratrum institutor et dux, paupertatis professor, patientiae forma, veritatıs praecox, sanctitatis speculum, et totius Evangelıcae perfectionıs exemplar, superna praeventus gratıa, ordınate progressu ab infimıs pervenit ad summa "In his compilation of saints' lives, Surius included most of Bonaventure's life of Francis of Assisi Surius excluded Bonaventure's last chapter on the miracles of Francis The life in Surlus is found in Ibid 10 112-79 I compared it with Bonaventure "Vita Franciscl," in Acta sanctorum Octrobris, 2 742-98 (Parıs and Rome Victor Palme, 1866) The chapter on Francis's miracles appears in $\imath$ dem, 783-98
} 
Finally, the devout emulation of Christ and the saints transformed a pious person into an example eventually followed by others. For Surius, these three processes were especially important in religious orders with their emphasis on community and cyclical emulation of holy predecessors. When Ribadeneyra wrote his lives of Jesuits after reading Surius's redaction, most of the first generation of the Society had died. To perpetuate the virtue and the piety of these non-canonised Jesuit 'saints' required something tangible and visible, namely a book.

\section{$\underline{\text { The Saint as Exemplar in Ribadeneyra's Flos Sanctorum }}$}

\section{Ribadeneyra on the Founders Dominic and Francis of Assisi}

Saintly virtue and the call to imitate such virtuous behaviour were recurrent themes in Ribadeneyra's hagiographical accounts of the founder-saints. Dominic, for example, during a famine sold off his goods including his books so that the acquired money could be used for the poor, since that was "the example of many young saints who also sold their estates to remedy the poor." ${ }^{448}$ The tendency towards finding exemplars and then following them presented itself when Dominic read Cassian's Conferences, which was for Dominic, a "paragon to obtain the virtues and stamp onto his soul the perfection of the Desert Fathers, which are represented in this book." ${ }^{449}$ For Ribadeneyra, reading hagiography was a part of the process of sanctification. As evident in Dominic's reading of Cassian, a saint was inscribed in a cycle of reading and saintly imitation into which the reader is drawn. The reader then perpetuated the continuity between saintliness

\footnotetext{
${ }^{448}$ Ribadeneyra, Flos sanctorum (1601), 112. "Y aviendo sucedido vna grande hambre, vendió las alhajas de su casa, y los libros de su estudio, para remediar las necessidades de la ge[n]te pobre y miserable; quedando en su pensamiento rico, por verse con los pobres pobre: y por el exemplo del santos moço muchos vendieron también sus haziendas, para remedio de los pobres"

${ }^{449}$ Ibid. 113. "Leya en este tiempo con mucha atención el libro de las Colaciones de Casiano, tomá[n]dole por dechado, para sacar virtudes del, y para estampar en su alma la perfección de los santos Padres del yermo, que en aquel libro se representan"
} 
and texts. Through Dominic, Ribadeneyra provided another example of the process of saintly imitation.

Ribadeneyra used Francis as an example of the importance of communicating these saintly exemplars during sermons. Preaching for Francis was a time for penance since "he often told his faults in the sermon, so that the congregation looked down on him" but he would also transition "towards other things more admirable but imitable, they were a certain indication of his great zeal and profound humility." ${ }^{450}$ The closing paragraph of Ribadeneyra's vita imparted the exceptional holiness of Francis as well as the necessity to replicate Franciscan virtue: "Let us all have great devotion to this most holy Patriarch. Let us imitate (in the manner that our weakness will allow) his heroic virtues. Let us be humble." also apparent amongst the Franciscans. In writing his life of Francis, Bonaventure "has stamped upon us and others who read it, the examples of virtue more divine than human, which this Seraph [Francis] radiated onto the world." depictions of saintly virtue were their emulation by Catholics witnessing the acts upon the page. Observible exemplars were internalised through making their mark upon the soul based on Ribadeneyra's use of imprimir and estampar.

The propagation of saintly conduct in these lives from the Flos sanctorum was embedded within an emergent Catholic identity. When Dominic arrived to engage with the Albigensians and convince them of their erroneous beliefs, the result as described by

${ }^{450}$ Tbid. 421. "Y quandopredicaua, muchas vezesdezía sus faltas en el sermón, para q[ue] le menospreciassen: y hazia otras cosas más admirables que imitables, que eran indicio cierto de su gran feruor, y humildad profundíssima."

${ }^{451}$ Ibid. 437-38. "Tengamos todos gran deuociónco[n] este santíssimo Patriarca. Imitemos (en la manera q[ue] nuestra flaqueza pudiere) sus heroycas virtudes. Seamos humildes."

${ }^{452}$ Ibid. 409. "q[ue] en escreuir esta vida tuuo san Buenauentura, para que se impriman en nosotros, y en los que la leyeren, los exemplos de virtudes, mas diuinos q[ue] humanos, con que este Serafín resplandeció en el mundo." 
Ribadeneyra was "that an enemy of the Catholic faith became a son of the church." 453 Part of this Catholic identity formation was contingent on the imitation of Dominic's or of the converted heretics' conduct. This re-enactment enabled Catholics to perform good works since "in imitation of Dominic, some rich Catholics were moved to found other similar [religious] houses." ${ }^{454}$ Dominic's conduct also prompted non-Catholics to convert. Dominic through "his most holy life, and heavenly doctrine, and many miracles that God had done through him... had converted almost a hundred thousand misguided and lost souls to the true and Catholic religion."455 In Ribadeneyra's life of Dominic, there was a constant reiteration of 'Catholic religion' or the 'true church' in order to accentuate the perceived disintegration of Christendom, while at the same time affirming the continued existence of an authentic and apostolic church.

Similar references to the 'true' or 'Catholic' religion or church appeared in Ribadeneyra's life of Francis in tandem with the implementation of saintly virtue in daily life. For example, Pope Innocent III's dream about Francis combined the rescue of the church in crisis with the exemplary sanctity of Francis:

When the Supreme Pontiff was sleeping one night greatly preoccupied by the calamities affecting the Church, he saw in his dreams the basilica of St. John Lateran, where he lived, threatened with great ruin andcrash to the ground. In this dream, a poor and rejected man put his shoulder under the basilica, and supported it. He understood by divine instinct that this poor man was none other than the glorious saint Francis, who by his examples and teaching has

\footnotetext{
${ }^{453}$ Ibid. 113. "La primera noche que llegaron á tierra de hereges [theAlbigensians], acertó á serlo el huésped de la posada: trauó platicas con él sobre las cosas de la religión, y fueron tan eficaces las razones que le dio, que de enemigo de la Fe Católica, le hizo hijo de la Yglesia."

${ }^{454}$ Ibid. 115. "Y á imitación suya se mouieron algunas personas ricas y Católicas á hacer otras casas semejantes"

${ }^{455}$ Ibid. 115. "La suma de [e]stos trabajos fue, que con su vida santíssima, y dotrina celestial, y con muchos milagros que el Señor obro por él, conuirtió casi cien mil almas erradas y perdidas, á la verdadera y Católica religión."
} 
sustaned the church of God, as he has sustained it in his lifetime, and as his blessed sons now sustain the church. ${ }^{456}$

Ribadeneyra's life of Francis correlated the love of God with obedience to the Catholic church in Rome as another expression of this nascent Catholic identity, since "Francis urged [other Friars Minor] by the love of God for holy poverty, patience, and to die for the faith of the holy Roman church. ${ }^{, 457}$ In the account of Francis, Ribadeneyra suggested that Catholics had to support the Papacy and the Roman church. Catholics also had to be prepared to suffer martyrdom for their confession.

The correlation between Catholic identity formation and readers deepened when the inclusion of Jesuit 'saints' was considered, especially when juxtaposed with the analysed lives of Francis and Dominic. As founders of the mendicant orders, Francis and Dominic initiated changes to medieval Christian life in the thirteenth century. While the Society of Jesus was not the same type of order, Ignatius occupied a similar place to Francis and Dominic within the Flos sanctorum. The later inclusion of other Jesuits as 'saints' only confirmed Ribadeneyra's desire to emulate the older religious orders and to situate Ignatius in the tradition of religious founders, such as Francis and Dominic. ${ }^{458}$ Jesuit

${ }^{456}$ Ibıd 416 "Porq[ue] acostá[n]dose el sumo Po[n]tificevna noche co[n] gra[n]des cuydados de las calamıdades q[ue] padecía la Yglesia, vıo en sueños, q[ue] elte[m]plo de san Iua[n] de Letrán, donde el habitaua, amenazaua gran ruyna, y se venía al suelo, y q[ue] un pobrezito y desestımado ho[m]bre ponía sus hombros debaxo del, y le suste[n]taua y por diuıno instınto ente[n]dió, que este pobrezito era el glorioso san Francisco, que por sus exe[m]plos y dotrinaauía de suste[n]tar la Yglesia de Dios, como la suste[n]tó en su vida, y ahora la suste[n]ta por sus bie[n]aue[n]turados hijos"

${ }^{457}$ Ibid 435 "Después los exortó al amor de Dios, de la santa pobreza, y paciencia, y á morır por la Fe de la santa Yglesia Romana"

${ }^{458}$ O'Malley, First, 93 "When in 1537 the companions of Parıs first began to preach in the Veneto, however, they did so in the open air and in the streets - a practice that continued throughout the period I am considering and that accounts for a great amount of the preaching in which the Jesuits engaged They believed they were thereby imitating the practice of Jesus, his disciples, and Paul They preached, therefore, in the streets, in public squares and markets, in hospitals, in prisons, aboard ships in dock, in fortresses, on playing fields, in hospices and hostels, in confraternities When Jesuits preached in sites like these, they were imitating their predecessors, the friars of the mendicant orders, but they also introduced the practice into localities where it had not been known and, as they saw it, imbued it with a new zest" 
readers imaged by Ribadeneyra as idealised saintly emulators endeavoured to sanctify

their own behaviour, since:

How many children, and how glorious, has this most holy Patriarch [Dominic] had? From saint Thomas Aquinas, light and master of the entire Catholic church; to saint Peter Martyr, protector of the Faith and knife of the heretics; to saint Hyacinth, a mirror of holy confessors; to saint Vincent Ferrer, Apostle of his time; to saint Antoninus, Archbishop of Florence, paragon of holy prelates... and to many other blessed sons and daughters, who in number and virtue shine in the Holy Catholic church, like stars in the sky. ${ }^{459}$

Jesuit readers of the Flos would have recognised Ignatius as a Patriarch and the other 'saints' featured in the 1609 edition, such as Xavier, Borgia, Gonzanga, and Kostka as the issue of a distinct Catholic identity. With the exception of Dominic, Aquinas, and Peter Martyr, the Dominicans in this passage (Hyacinth, Vincent Ferrer, and Antoninus) appeared alongside the Jesuits and the other extravagantes. ${ }^{460}$ This practice was another perpetuation of the cycle of the sanctity transmitted between founder and followers. It was also indicative of the Jesuits' attempt to integrate the order within early modern Catholic conceptions of saintliness.

\section{Ribadeneyra on the Doctors Thomas Aquinas, Bonaventure, and Augustine}

Ribadeneyra recalled the monastic community that Augustine founded and operated "according to the way of life and the rule that the Holy Apostles followed...more

\footnotetext{
${ }^{459}$ Ribadeneyra, Flos (1599), 133. "Que de los hijos tantos y tan gloriosos; que ha tenido este santíssimo Patriarca? A vn santo Tomas de Aquino, luz y maestro de toda la Yglesia Católica; á un san Pedro Mártyr, amparador de la Fe, y cuchillo de los herejes; á vn san Iacinto, espejo de santos Confessores; á vn san Vicente Ferrer, Apóstol de su tiempo; á vn san Antonino Arçobispo de Florencia, dechado de santos Prelados...y á tantos otros bienaue[n]turados hijos e hijas, q[ue] en número y virtud resplandecen en la santa Yglesia Católica, como estrellas en el firmamento?"

${ }^{460}$ Butler, 4: 30-31, 5: 13-15; Burke, "Counter-Reformation Saint," 137; Ditchfield, "Coping with the 'Beati Moderni'," 418-19. Hyacinth (Jacek in Polish, Jacinto in Castilian) was canonised in 1594. Antoninus of Florence or Antonino de Pierozzi became an official saint in 1523, while Vincent underwent canonisation in 1455. Burke states that between 1588 and 1767, the Franciscans had a nun and seven friars canonised, while the Dominicans had three nuns and four friars, and the Jesuits had six.
} 
by example, than by regulations.."461 Through apostolic imitation, Augustine created a religious life and an identity based on saintly exemplars. At the same time, Augustine created a religious community that was not bound to a rule, something that resonated with the Society. In turn, future religious turned to Augustine to construct their own religious lives and identities through his example. Ribadeneyra contrasted the thirteenthcentury foundations of the Augustinians, the Servites, and the Dominicans as an illustration of the founders' emulation of Augustine's life:

By which, the holy and enlightened order of the Hermits of St Augustine (in which there has always been the most learned men of an exemplary life) was the daughter of this blessed Father. Of all the numerous Canons regular, all flowed from this fount. The Servites recognise St Augustine as their master, and serve under his rule, followed by many and very distinguished monastic members. And the great Patriarch St Dominic was a Canon regular of St Augustine. Dominic gave to his illustrious order the Rule of this saint under which he himself had lived. And by observing it, Dominic arrived at the perfection that he achieved. ${ }^{462}$

Through this iteration of an imitative genealogy, Ribadeneyra placed the Society of Jesus within a framework of saintly imitation.

Repeatedly in the Flos sanctorum, a saint living in an era of discord sought to reproduce the life and the practices of a holy predecessor. This process began with Christ and only ended with the Second Coming. As the apostles emulated Christ, the cycle of saintly imitation persisted in a variety of forms. Examples in Ribadeneyra's Flos sanctorum included his association of Augustine with the apostles, Dominic with

\footnotetext{
${ }^{461}$ Ribadeneyra, Flos (1601), 269. "y edifico dentro de la Yglesiavnmonesterio de Clerigos, segun el modo y regla que dexaron los santos Apostoles y mas con su exemplo, q[ue] con preceptos."

462 Ibid. 282 "Porque la sagrada y esclarecida orden de los Ermitanos de san Agustin (en la qual siempre ha auido, y ay, varones doctissimos, y de vida exemplar) en hija de [e]ste B. Padre. Las religiones de los Canonigos reglares, que son muchas, todas manaron de [e]sta fuente La de los Serutas reconoce á san Agustın por su maestro, y milita debaxo de su regla y tras muchas y muy insignes monacales, y militares Y el gran Patriarca santo Domingo fue Canonigo reglar de san Agustın, y dıo á su ıllustrıssıma orden la regla de [e]ste Santo, en la qual el mismo auıviuıdo; y por la obseruancia de [e]lla llegado á la prefecio[n] que llegó "
} 
Augustine, or Ignatıus with Dominic. Imitatıon of virtue was not from a single source, but involved numerous saintly individuals. Augustine modelled his conduct on the apostles. According to Ribadeneyra, Augusitne also mimicked Ambrose of Milan's abilıty as a preacher and a writer, which moved Augustine towards excellence in recitıng the liturgy and composing theological and doctrinal texts. ${ }^{463}$ Holy men and saints served as examples of an ideal Christian life whether the rhetorician Victorinus or St Antony the Anchorite:

Simplicianus had told Augustine about Victorinus's conversion to our holy Faith. Victorinus had taught rhetoric in Rome, so successfully that he was publicly recognised with a public statue. When he was old and proficient in all disciplines, he left paganism, and turned his eyes and heart to the Lord. This example awakened in St Augustine a desire to imitate him. He was also inspired by the life of St Antony the Abbot.Until that time, he had not heard anything about Antony's life. Augustine was told by the noteworthy African gentleman from his region named Ponticianus about two gentlemanly servants of the Emperor. After reading the life of Antony in the city of Trier, they had renounced all worldly things They became monks, giving themselves entirely to serving the Lord. ${ }^{464}$

Through the integration of Christian virtue from saints and holy men, Augustine underwent sanctification as an instance of salvation through works. Ribadeneyra envisioned readers of saints' lives as a way of influencing others through their engagement with his Catholic model of saintly imitation.

In the Flos sanctorum, the practice of reading featured routinely within Ribadeneyra's cycle of saintly imitation. The spiritual progression made by Augustine

${ }^{463}$ Ribadeneyra, Flos (1601), 259-60 On Augustıne's copious writıngs. Ibıd. 275ff.

${ }^{464} \mathrm{Ib} ı d$ 261. "Porq[ue] Simplicianoco[n]tó á Agustın la co[n]uersion á nuestra santa Fé de Vıctorino, que auı enseñado Retorıca en Roma, y alcançado en ella, que se le pusıessepublicamente estatua y siendo ya viejo, y en todas las cie[n]ciassapientıssimo, auıadexado la Ge[n]tilidad, y buelto los ojos y el coraçon al Señor y con este exemplo se encendıo San Agustın, co[n] desse de imıtarle. Tambıen le esforço, el auerle refendo vncauallero principal Afrıcano, y de su tıerra, llamado Pontıcıano, la vida de san Antonıo Abad (de la qual hasta aq[ue]lla hora no auı tenıdo notıcia alguna) y q[ue] dos caualleros criados del Emperador, leyendola en la ciudad de Treuerıs, auranrenu[n]ciado todas las cosas del sıglo, y hechose religiosos, y entregadose enteramente al seruicio del Señor" 
was facilitated through replicating the behaviour of holy men and women and through visual performance and written media. For instance, Augustine abandoned the Manicheans through the intervention of a Catholic writer: "And having read a dispute, that a Catholic, named Elpidius, had had with [the Manicheans], Augustine began to despise that sect." ${ }^{465}$ Spiritual epiphany emerged through both good conduct and good reading. In the Augustinian examples that Ribadeneyra employed, what assured his status as a saintly doctor were the practice of reading, Catholic virtue, and the dissemination of theology

In turn, Augustine served as an example for others to follow. For example, Thomas Aquinas appropriated the exceptional from Augustine whose life was a manual for saintliness:

Especially the scholastics, who examine, deliberate, and fathom with the weight of reasonthe truths of holy theology, have Augustine as their guide and teacher. And most of all, the angelic doctor St Thomas [Aquinas], was clothed in the spirit and teachings of St Augustine in such a manner, that it seemed to have transformed him, so that he drank it and soaked it in like a sponge. Thus one can understand that given the greatness of the Master, so too was the discipline just as great. ${ }^{466}$

Ribadeneyra emphasised the ongoing imitation of their predecessors' conduct and piety.

The entry into this cycle of duplicating the lives of saints through reading was evident in Ribadeneyra's lives of doctors and founders. A continued and sustained invocation of saintly figures in church history existed for the thirteenth-century mendicant doctors Thomas and Bonaventure. Reading constituted a crucial component of Thomas and

\footnotetext{
${ }^{465}$ Ibıd 259 "Y auıendoleydovna disputa, que vn Catolıco, llamado Elpídıo, auıa tenıdo co[n] ellos, come[n]ço á despreciar aquella secta"

${ }^{466}$ Ribadeneyra, Flos (1599), 275 "Especialme[n]te los Escolastıcos, que examınan, apura[n], y pesan con el peso de la razon, las verdades de la santa Teologia, le tienen por su guia, y maestro $\mathrm{Y}$ principalmente el Doctor Angelico santo Tomas, se vistıo del espiritu y dotrina de S[an] Agustın, demaneı, que parece auer se transformado en el, y beuidola, y empapadose en ella, como vna esponja de donde se puede entender, quan grande fue el Maestro, pues tan grande fue el dicipulo "
} 
Bonaventure's sanctity The circulation of writings enabled the formation of a community through communicating doctrine and ideals of Catholic conduct. For instance, in the life of Bonaventure, Ribadeneyra related the episode of Thomas's visitation to Bonaventure:

Another tıme, St Thomas went to visit St Bonaventure. There he found Bonaventure writıng the life of St Francis, his father. Thomas did not wish to interrupt or to hinder Bonaventure Leaving Bonaventure, Thomas said Let us leave the saint that labours for another. ${ }^{467}$

This passage portrayed the transmission of sanctity through texts and the imitative relationships amongst religious men. Anyone who read or observed the life of a sant became a witness and a participant in early modern Catholic mimesis. ${ }^{468}$ For Thomas, Bonaventure writing Francis's life indicated the sanctity of the subject and its author. This episode also appeared in detail in Ribadeneyra's life of Thomas. ${ }^{469}$ While the narrative differed little from that found in Bonaventure's life, Ribadeneyra explicitly stated that the purpose of hagiography was to encourage its readers towards sanctity. Bonaventure's writings set aflame the will and moved the reader towards virtuous living. ${ }^{470}$ The shared holiness of the doctors was also enumerated through the description

${ }^{467}$ Ribadeneyra, Flos (1601), 26 "Otra vez ye[n]do á visitar santo Tomas á S[an] Buenauentura, halló que estauaescriuiendo la vida de san Francisco su padre, y no le quiso interrumpir, mi estoruar, antes le dexó, dizıendo Dexemos al Santo que trabaje por otro Santo"

${ }^{468}$ Francisco Zurbarán, Saint Bonaventure refers Saint Thomas Aquinas to the Saviour, 1629, Kaiser Friedrich Museum, The Paintings of Zurbarán, by Martın S Soria (New York Garden City Books, 1953), 48 These themes appear in Zurbarán's paintıng that features Bonaventure's study with its volumes by Jerome and Augustıne (amongst others). Behınd a screen, however, is an image of a crucifix that Bonaventure shows Thomas Exemplarly Christianity requires the imitation of Christ and the saints.

${ }^{469}$ Ribadeneyra, Flos (1599), 370 "y assi se visitauan y comunicauan como verdaderos y santos hermanos: y vndia yendo santo Tomas á visitar á S[an] Buenauentura, y halla[n]do que estaua ocupado en escreuir la vida de su padre S[an] Francisco, no le quiso inquietar, antes se boluı sin verle, diciendo. Dexemos al santo trabajar por otro santo Porque como el era tan santo, conocía bie[n] la santıdad de Buenauentura, el seruicıo que se hazeá nuestro Señor en escriurr las vidas de los Santos, para que otros las ımiten, quando se haze de la manera que lo hizo S[an] Buenauentura en la vida que escriuio de S[an] Francisco"

${ }^{470}$ Ribadeneyra, Flos (1601), 30 "Lo qualodia se echa bien de ver en los muchos y doctıssimos libros q[ue] dexó escritos; en los quales resplandecen todas estas virtudes, y co[n] vnadotrına celestıal vn fuego de amor diuıno, q[ue] alu[m]bra el entendımiento de los q[ue] los lee[n], y abrasa la volu[n]tad, y los enternece y mueueestrañamente " 
of their piety and fraternal relationship. The mention of brotherhood bolstered the representation of these behavioural models as builders of religious communities.

At the same time, the nature of this imitation involved not only saints far removed from the thirteenth century, but the emulations of contemporaries. Examples of these practices included the mimicking the lives of their order's founders or using contemporaries as a basis for imitation. Ribadeneyra emphasised equally the importance of reading and writing in a doctor's life. Through the reading of Cassian's Conferences, Thomas imitated his order's founder. Dominic read the same text to inspire religiosity and to acquire models for orthodox behaviour:

the Saint stopped, and responded with great silence, forbearance, and suffering. Without being distraught or opening his mouth to complain, he provided every example of humility and gentleness... With this same humility he came to read frequently and attentively the Conferences of the Holy Fathers written by Cassian, imitating in this way his father, St Dominic, and making use of this reading for his spirit and progress, as a novice should. .This same humility shines through admirably in that singular modesty with which St Thomas treated the other saints and doctors of the church in his writings. He venerated the doctrine of the masters as well as explaining and making obvious whatever was unclear and uncertain. ${ }^{471}$

In Ribadeneyra's conception he wished to impart on the readers of the Flos sanctorum, Catholic identity and conduct were the culmination of the emulation of a sanctified predecessor or contemporary's behaviours, whether through reading or writing.

Yet a doctor also had to foster the religious community through exemplary piety. Bonaventure's sanctity was evident in his teaching, his governance of the Franciscans, his

${ }^{471}$ Ribadeneyra, Flos (1599), 377 "el Santo calló, y respondı con vn silencio grande, paciencia, y sufrimiento, sin alterarse, nı abrir su boca para quexarse, dando en todo exemplo de humıldad y mansedumbre D[e] esta misma humildad procedia el leer ta[n] amenudo, y co[n] ta[n]tocuydado las Colaciones de los santos Padres, escritas por Cassiano, imita[n]do en esto á su padre Sa[n]to Domıngo, y siruie[n]dose de la lecio[n] d[e] ellas, para su espiritu y aprouechamie[n]to, como vnnouicio lo pudiera hazer .Esta misma humildad respla[n]deceadmirableme[n]te en aq[ue]lla modestia singular, co[n] $q[u e]$ $\mathrm{Sa}[\mathrm{n}]$ to Tomas trata en sus escritos á los otros santos y Dotores de la Yglesia, reuere[n]cia[n]do su dotıına como de maestros, y exponıe[n]do y da[n]do bue[n] sentıdo á lo q[ue] esta escuro y dudoso " 
wisdom, and the devout life he led. ${ }^{472}$ With Thomas, his external comportment betrayed his holiness, as when "every [classmate] laid eyes on [Thomas] for his nobility, his intelligence, and much more for his example and for the dignified and spiritual modesty he radiated." ${ }^{, 73}$ Thomas and Bonaventure through their outward demeanour revealed the inner sanctity that encouraged their religious communities towards pious and orthodox conduct. Ribadeneyra's life of Thomas depicted this convergence of sacred qualities and the interconnectedness of pious reading and virtuous conduct. Sanctity was not singularly contingent on good works, such as charity, prayer, or asceticism. In the case of mendicant doctors, reading texts enhanced and reinforced devotion and corroborated the doctor's piety. In this description of Thomas by Ribadeneyra, the concatenation of ideal conduct and of textual practices was made plain:

He fled from chatter and conversation. He gave much to prayer and the rest of his time he spent reading, listening, studying, and meditating with great attention upon what he had read and heard...From here, all of the friars began to look at him through different eyes. They began to esteem the ability and aptitude of Thomas, as well as to venerate his virtue and composure. His brothers understood that the great knowledge he displayed was more a communication from heaven, than acquired through study. For it seemed to them that without the special aid and favour of God, it would have been impossible for a human mind to have reached the point of wisdom that he had achieved, in such a brief time. ${ }^{474}$

${ }^{472}$ Ribadeneyra, Flos (1601), 29. “Auie[n]do pues gouernado S[an] Buenaue[n]tura muchos años su sagrada religion, y floreciendo ella por su gouierno, y el santo por la vida admirable, y dotrina excelente, y prudencia singular, de que Dios le auia dotado."

${ }^{473}$ Ribadeneyra, Flos (1599), 363. "Con el grande viuo ingenio q[ue] tenia, apren[n]dio de tal manera aquella cie[n]cias, $\mathrm{q}[\mathrm{u}] \mathrm{e}$ dexó muy atrasá todos sus co[n]dicipulos, y dio muestras de lo que con el tiempo auia de ser. Todos ponian los ojos en el, por su nobleza, por su ingenio, y mucho mas por su exemplo, y por la graue y alegre modestia con que resplandecia."

${ }_{474}$ Ibid. 368. "Huya de platicas, y de conuersaciones. Dauase mucho á la oracion, y todo el resto del tiempo gastaua e leer, oyr, estudiar, y meditar con grande atencion, lo que auialeydo, y oydo...De aqui come[n]çaron todos los frayles á mirarle con otros ojos, y á estimar la habilidad y suficiencia de Tomás, y reuere[n]ciar su virtud y compostura, y entender, que aquella tan gran cie[n]cia q[ue] mostraua, era mascomunicacion del cielo, q[ue] adquirida por estudio, por parecerles que no era possible, que ningu[n] ingenio humano, en ta[n] breue tiempo, huuiesse podido llegar á aquel pu[n]to de sabiduria que el tenia, sin particular socorro y fauor de Dios." 
While Ribadeneyra wrote about the importance of divine inspiration to Thomas, his reading of books and human learning were also important to Ribadeneyra's conception fo Thomas's sanctity. Thus, Ribadeneyra normalised the practices for santly doctors associated with texts such as reading. It enabled them to enter into the sequence of imitation which spanned the present and the apostolic church. Another way of emulating sanctity was through the observation of saintly contemporaries.

\section{Ribadeneyra on the Apostles Peter, Paul, John, and James the Greater}

Reform movements of the sixteenth century often invoked the early church as a template for Christian sanctity and church governance. In the midst of increasing confessionalisation, the apostolic church served as a historical construct employed as a source of ecclesiastic precedents and tradition as well as foil to the perceived decadence and decline of the present. Ribadeneyra depicted apostolic saints as models of conduct. He also used the apostles' lives with the exception of Paul and James the Greater to assert specific components of Catholic identity: Peter as the founder of the Roman church and John as the sacred historian.

With respect to imitation, Ribadeneyra excluded Paul from his litany of apostolic saints. This omission could be due to Paul's status as an apostolic late-comer, since he was not one of the original twelve. ${ }^{475}$ Though early modern Catholics maintained the importance of Paul within the corpus of saints, Ribadeneyra nonetheless sought to exclude Paul from the process of observational emulation found in the Flos sanctorum. ${ }^{476}$

${ }^{475}$ In his vision on the road to Damascus, Christ called Paul an apostle. After which, Paul referred to himself as the apostle of the Gentiles The ambiguity of his apostolic title is evident in his first letter to the Corinthians, where he defends his appointment as an apostle by Christ but also suggests his inferiority to the earlierapostles due to his part in Stephen's death, see. Acts 9. 1-9, Romans 11 13, Galatians 28,1 Corinthians 91 ff, 159.

${ }^{476}$ O'Malley, First, 73 The decision to exclude Paul from the litany of imitable saints by Ribadeneyra is baffling since the Society viewed Paul as their model for the minıstry. Nadal had stated: 
Meanwhile, Ribadeneyra treated Paul's feast day companion Peter as a worthy model of behaviour. The source of Peter's sanctity, according to Ribadeneyra, was the saint's innate virtue as well as his imitation of Christ. ${ }^{477}$ Peter as an apostle continued this legacy of imitation through following the example of Christ especially through crucifixion. For example as Peter was nailed upon his cross, it provided "an opportunity to imitate Christ", so that Peter "could match the beloved and immense love with that torment and death on the cross, with which the same Lord himself on another Cross had given his life for him. ${ }^{\$ 478}$ Ribadeneyra likened Peter's death to the consummation of a pilgrimage (peregrinacion), itself a re-enactment of a historical and a religious event. ${ }^{479}$ In the process, Ribadeneyra depicted Peter as the founder of the Christian religion and the head of the entire church, whose "spiritual jurisdiction is more widespread and extensive today, that ever was his temporal power. ${ }^{480}$ While reform played an active role in early modern Catholicism, it coexisted with the affirmation of religious and ecclesiastical traditions such as pilgrimages and recognition of the pope as a spiritual authority. Also apparent in Ribadeneyra's account of the apostolic church was the beginnings of an observational approach to imitation. Through the observation of Christ's life and passion, the apostles acquired a template of sanctified action.

"Paul signifies for us our ministry." Ribadeneyra does not provide any justification in his letters or elsewhere in the Flos sanctorum.

${ }^{477}$ Ribadeneyra, Flos (1599), 681. "lo qual no se lee de otro santo, ni aun de Christo nuestro Redentor: porque en esta parte quiso que su sieruo se aue[n]tajasse mas, é hiziesse mayores milagros, no por su virtud, sino por la de su Señor."

${ }^{478}$ Ibid. 689. "Alli le desnudaron, y enclauaron en la Cruz, con inestimable gozo y alegria del beatissimo Apostol, por la merced que recebía del Señor, dandoleocasion de imitarle, y co[n] aquel tome[n]to y muerte de Cruz corresponder de la manera que podia al amor entrañable, é inmenso, con q[ue] el mismo Señor en otra Cruz auia dado su vida por el.

${ }^{479}$ Ibid. "De [e]sta manera acabó el curso de su peregrinacion el Principe de los Apostoles San Pedro, imitando con su muerte la muerte; y con su Cruz la Cruz de Christo"

${ }^{480}$ Ibid. "y plantando la Religion Christiana, y regandola con su sangre en aquella ciudad que en aquel tiempo era señora del Imperio, y despues por la Catreda y sucession de San Pedro, auia de ser cabeça de todos los fieles que estan derramados por el vniuerso siendo mas estendida y dilatada por la juridicion espiritual que agora tiene, que jamas lo fue por la potestad te[m]poral." 
Ribadeneyra's depiction of Peter made a discernible assertion of Catholic identity by invoking Peter as the founder and the leader of the church. In particular, Ribadeneyra described the first pope as a "unique and universal Shepherd of [Christ's] church" ordained by Christ. After Christ's ascension to Heaven, "Peter started to exercise his office....when the Apostles and all disciples were all together in the Cenacle; he proposed to them as head [a replacement for Judas]. ${ }^{, 481}$ Earlier in the account, Ribadeneyra conveyed the supernatural blessing bestowed upon Peter to lead the church:

it was Peter who God chose to be his Vicar on earth, and the sole and universal pastor of his entire church, and to whom the Lord gave the keys of the church's treasury, the dispensation of the inestimable price of his blood, and our redemption. As Peter was his worthy minister and shepherd, he was decorated with all the necessary graces and virtues. ${ }^{482}$

Throughout the life of Peter, Ribadeneyra usually referred to Peter as the "universal Shepherd" as a justification of the papacy's legitimacy. ${ }^{483}$ Ribaedeneyra used the apostles as the start of different lineages whether his depiction of John as a protodoctor of the church or his portrayal of Peter as standing at the beginning of a tradition of papal sovereignty. For Ribadeneyra, to be Catholic was to regard the Pope as the highest spiritual authority of this world. This "universal Shepherd" not only wielded authority over the Western church, but also the Eastern church since Peter had founded the Roman,

\footnotetext{
${ }^{481}$ Ribadeneyra, Flos (1599), 680. "y le hizo Pastor vniuersal de su Yglesia, y assicomençó á exercitar su oficio, luego q[ue] subioChristo nuestro Redentor al cielo, quando estando los Apostoles y dicipulos todos juntos en el Cenaculo, les propuso como cabeça, que eligiessen otro en lugar de Iudas, y cayó la fuerte sobre S[an] Matias, y fue contado en el numero de los dozeApostoles."

${ }^{482}$ Ibid. 679. "Finalmente Pedro fue á quien Dios escogio por su Vicario en la tierra, y por vnico y vniuersal Pastor de toda su Yglesia, y á quie[n] dio las llaues del tesoro della, y la dispensacion del precio inestimable de su sangre, y de nuestra redencion: y para que fuesse digno ministro y pastor suyo, le adorno de todas las gracias y virtudes que auia menester."

${ }^{483}$ While the "unique" component of Peter's title does not always appear, Ribadeneyra portrays Peter as the "universal Shepherd." Ibid. 684 and 686.
} 
Alexandrian, and Antiochean churches. ${ }^{484}$ Apparent in Ribadeneyra's life of Peter, the Catholic church was the unversal church and wished to reincorporate not only Protestants, but also Christians of the eastern churches, under the control of the Pope.

The construction of tradition through history reappeared with Ribadeneyra's list of places where Peter dispatched bishops and priests. The 1nventory differs little from the European countries considered Catholic. Italy, France, Spain and its European holdings, such as Sicily. Yet this endeavour extended outwards to include Africa and "other islands" mirroring the global Jesuit enterprise to save souls. ${ }^{485}$ Rubadeneyra portrayed Peter as the "universal shepherd" of the Catholic church who governed the faithful of the world from the site of Peter's martyrdom and the Papacy: Rome.

Pilgrimage also appeared in Ribadeneyra's account of James the Greater, the focus of the famous trek to Santiago de Compostela in Galicia that housed his relics. ${ }^{486}$ The pilgrimage to Santiago de Compostela persisted after the Protestant Reformations for Catholics who desired to attain penance. Akin to observational emulation through saints' lives, pilgrimages recreate historical events for the purposes of devotion. In turn, these practices routed in religious history contribute to conceptions of confessional identity.

${ }^{484}$ Ibıd 692 "Finalmente toda la YglesiaCatolica ha reconocıdo siempre, y reconoce á Pedro por pastor vnico y vnıuersal, y ha reuerte[n]ciado por Prımaciales y Patriarcales las Yglesias que fundó San Pedro, que son, la Romana, Alexandrina, y Antıchena"

${ }^{485}$ Ibıd 684. "Y assi S[an] Pedro boluiendo los ojos por todas ellas, y abraça[n]dolas con su vigılancia y cuydado pastoral, las proueyó de pastores, y embio por toda Italıa, Francia, España, Africa, Sicılia, y otras Islas, Obıspos y Sacerdotes que las enseñassen, y alumbrassen con los resplandores del Euangelıo "The Jesuts between 1540 and 1615 had founded numerous establishments across Europe, especially in Spain, Italy, Belgium, southern Germany, and France, as well as others in Poland and Latvia Outside of Europe, the Society had active missions in India, Africa, eastern Asia (especially China and Japan), Brazıl, and the Spanish colonies in the Americas and Asıa On these phenomena, see Bangert, History of the Society, 83-96, 142, 148-74. On the Asian mission in partıcular, see Florence Hsia

${ }^{486}$ Ribadeneyra, Flos (1601), 72. "El qual por varios sucessos y rebueltas estuuo muchos años secreto y escondıdo, hasta que el Señor le reuelo y edscibrio, y se trasladó á la ciudad de Compostela, donde es reuerenciad, no solamente de aquella prouınicia de Galızıa, y de todos los Reynos de España, sino tambien de las otras naciones de la Christianıdad, q[ue] vienen en romerıa á visitarle y venerarle, con gran deuocion y concurso como en el dia de su translacion, q[ue] se celebra á los 30 de Diziembre, mas largamente se dırá." 
Ribadeneyra, however, chose to emphasise the desirability of imitating his virtues and his continued presence as an intercessor:

Give us, our Lord, thanks for the intercession of the same Apostle, to imitate his praiseworthy virtues in such a manner that we may deserve in this life to be protected from our invisible enemies that on every side surround us, and in the other to enjoy the glory and the crown that he enjoys, and will enjoy forever and ever. ${ }^{487}$

Ribadeneyra's assertion of perpetual sainthood was related to seventeenth-century Spanish debates about James. Early seventeenth-century Spain dealt with the copatronage controversy, where churches, religious orders, and cities disagreed over the 'national' patron saint.

In some circles, James had become an irrelevant figure since a 'Moor-slayer' was unnecessary due to the end of the Reconquista more than a century earlier. Others felt that the veneration of James had to persist since he was tightly woven into Spanish and particularly Castilian history. In this midst, other parties suggested the elevation of Teresa of Ávila to co-patron saint of Spain, especially after her canonisation in 1622. The result was bitter discord over whether James, Teresa, or both were to be the patron saints of Spain. ${ }^{488}$ While he died in 1611 , Ribadeneyra sought to emphasise the saint's virtues rather than the more doubtful aspects of the received accounts of his life due to the perceived legendary nature of James's biography. James, unlike the other Apostles, did not feature extensively in the New Testament, hence the lack of canonical information for Ribadeneyra to construct a narrative. Yet Ribadeneyra also trumpeted James's triumphs

${ }^{487}$ Ibid. 74. "Denos nuestro Señor gracia por intercessio[n] del mismo Apostol, para imitar sus admirables virtudes, de tal manera, q[ue] merezcamos en ésta vida ser defendidos de nuestros enemigos inuisibles, que por todas partes nos cerca[n], y gozar en la otra de la gloria y corona q[ue] el goza, y gozará por todos los siglos de los siglos."

${ }^{488}$ Erin Kathleen Rowe, Saint and Nation: Santiago, Teresa of Avila, and Plural Identities in Early Modern Spain (University Park, PN: Pennsylvania State University Press, 2011), 20-106. 
against the Moors through saintly intercession. ${ }^{489}$ More importantly, Ribadeneyra employed James not necessarily as a model for confessional conduct, but as an affirmation of a distinctly Iberian tradition, tracing devotion in Spain back to the early church. $^{490}$

For James's older brother, John, Ribadeneyra depicted him as an exceptionally imitable saint. ${ }^{491}$ Throughout the hagiographical account, Ribadeneyra emphasised that John 'gives to us' a life and examples that should be internalised by Catholics. ${ }^{492}$ This exceptional piety began in youth, among John's brothers: "John is the first-born, is the paragon, and the model of all the others. ${ }^{, 493}$ Akin to James, Ribadeneyra presented John as an intercessor whose virtues and examples should be imitated to achieve Christian perfection. ${ }^{494}$ Brothers provided an enviroment for sensory-based imitation, whether the sons of Zebedee or Jesuits. Yet an equally important facet of John's imitible life was his creation of texts that document his observation of Christ's life, whether in his Gospel, Revelation, or his letters.

${ }^{489}$ Ribadeneyra, Flos (1601), 72-74.

${ }^{490}$ Rowe, 35-36. See also Katherine Elliott van Liere, "The Missionary and the Moorslayer: James the Apostle in Spanish Historiography from Isidore of Seville to Ambrosio de Morales," Viator 37 (2006): $519-43$.

${ }^{491}$ Mark 3:17. "James son of Zebedee and John the brother of James (to whom he gave the name Boanerges, that is, Sons of Thunder)." Cp. Ribadeneyra, Flos (1601), 67. "El Glorioso Apostol Sa[n]tiago el Mayor, luz y Patron de las Españas, fue natural de la prouincia de Galilea, hijo de Zebedeo, y de Maria Salomé, y hermano mayor de san Iuan Euangelista, y primo de Iesu Christo, segun la carne."

${ }^{492}$ Ribadeneyra, Flos (1601), 747. "Dandonos exemplo de la prontitud con q[ue] auemos de obedecer al Señor de todo lo criado, quando el nos llama, y nos propone alguna cosa de su seruicio como lo hizo S[an] Iuan, q[ue] por ser mas moço, y estar en la flor de su juue[n]tud, se deue estimar mas lo que hizo." Ibid. 755. "Mas como el era como vn Sol resplandecie[n]te, y diuino, con los rayos de su dotrina, y de su luz, deshazia las nieblas espessas de la ignorancia de aquella gente: y con los exemplos de su celestial vida, y con la dulçura, y santidad de sus costu[m]bres, y suauidad de su conuersacion, ablandaua, y atraía para Iesu Christo, á los que antes estauan tan lexos del, y biuia[n] en la sombra de la muerte." Ibid. 762. " $\mathrm{Da}[\mathrm{n}]$ do co[n] este hecho ta[n] ilustre exe[m]plo á los Perlados del cuydado y zelo q[ue] deue[n] tener de las almas de sus subditos: y e[n]seña[n]donos $\mathrm{q}[\mathrm{ue}]$ la verdadera penite[n]cia restituye al ho[m]bre la gracia $\mathrm{q}[\mathrm{ue}]$ por el pecado auia $\mathrm{p}[\mathrm{e}] \mathrm{dido} . "$

${ }^{493}$ Ibid. 751. "Iua[n] es el primogenito, es el dechado, y modelo de todos los otros"

${ }^{494}$ Ribadeneyra, Flos (1601), 768. "Encomendemonos con gra[n] deuocion á el, tomemosle por intercessor, imitemos sus virtudes y exemplos, y tentendamos, q[ue] pues la suma de la perfecion Christiana consiste en la caridad y enel amar, y ser amados de Dios" 
Both in person and through his texts, John disseminated Christian doctrine throughout the nascent church Ribadeneyra described the Gospel of John as an "evangelical history" ${ }^{495}$ When compared with the other evangelists,

When he wrote of Christ, and because Christ was both God and man, John had to declare (as a good historian) Christ's divinity and his humanity so that we would know who Christ was The other evangelists (as Sts Jerome and Augustıne said) wrote of the Lord, declarıng his humanity, his life, and the wonders he did in which God was revealed ${ }^{496}$

Ribadeneyra asserted that John's lıfe of Christ revealed both the divinity and humanity of the Son of God ${ }^{497}$ Subsequent sacred histories revealed the sanctity and the humanity of its subject, something implied by Ribadeneyra but never stated outright Reading, therefore, provides the integral gateway into the the cycle of imitation that began with Christ When direct observation was not possible, the sacred history provided a mirror of

${ }^{495}$ Ibid 753 "Esto es lo $q[$ [ue] hallamos en la historia Euangelıca de S[an] Iuan"

${ }^{496}$ Ibıd 758 "Porq[ue] como el escriue de Christo, y Christo es Dios y ho[m]bre, auia de declarar (como bue[n] historiador) su diuinidad, y su humanidad, para que supiessemos quien era Los otros Euangelıstas (como dize[n] S[an] Geronımo, y S[an] Agustın) escrıuen del Señor, declarando su humanıdad, su vida, y las marauillas que hizo, en las quales se mostraua Dios" The italıcs are my own

${ }^{497}$ Ribadeneyra listed his sources as Jerome's Against Jovintan and Augustıne's Thirty-Sixth Tractase on John That Tractase focuses on John 8 15-18 The 1dea of John's superlative portrayal of Christ's divinity appears in Augustine when compared with the other evangelısts Augustine, Tractates on the Gospel of John, trans John W Rettig, 5 vols (Washington, D C Catholic University of America Press, 1993), 181 "In the four Gospels, or rather the four books of the one Gospel, the holy Apostle John, not unjustly compared to an eagle because of his spiritual understanding, has elevated his preaching more highly and much more sublimely than the other three And in this elevation of his, he also wanted our hearts to be elevated For the three other evangelısts, as though they were walkıng on earth with the Lord, a man, sald few things about his divinity, but this [evangelıst], as if he loathed to walk upon the earth, as he thundered at the very beginning of his discourse, elevated himself not only above the earth and above all the circuit of air and sky, but also above even the host of angels and above the whole herrarchy of invisible powers [cites John 1 1-3] Harmonius to such a sublime beginning as this, he also preached the rest and he spoke about the divinity of the Lord as has no other man "

Jerome, meanwhile, explores this conception through Paul and John's letters Jerome discusses the impossibility of recreatıng Christ's divinely-inspired nativity, but we can imitate his life I think Ribadeneyra uses Jerome as an example of the inherent duality of saints, their possession of the divine, whıle being very human Jerome, "Liber duo adversus Jovinianum," in Patrologıae cursus completus Series latina (Parıs Vrayet, 1844-96), 23222 "Beatus quı Paulı simılıs erıt Felıx quı audıt Apostolum praecipientem, non igno scentem Hoc, inquit, volo, hoc desidero, ut imitatoresmeisitis, sicut ego Christ1 Ille virgo de Virgine, de incorrupta incorruptus Nos quia homines sumus, et natıvitatem Salvatoris non possumus imitarı, imitemur saltem conversatıonem Illud divinitatıs est et beatıudınıs, hoc humanae conditionis est et laboris Volo omnes homines similes mel esse, ut dum mei similes sunt, similes fiant et Christi, culus ego simılis sum [Cites 1 John 16$]$ " 
the sanctified life. The reader, akin to the apostle, became a witness to the life of Christ. $^{498}$

\section{Ribadeneyra on the Martyrs Sebastzan, Justus and Pastor, as well as Stephen}

Martyrs were important to Jesurts as essential constituents of the church militant. They frequently featured in the order's visual culture. ${ }^{499}$ Ribadeneyra placed the lives of martyrs within his formulation of saintly genealogies. Yet because of their disparity and diversity, martyrs posed a problem. Ribadeneyra maintained that forfeiting one's life for Christ was an important aspect of the religious calling. ${ }^{500}$ The sheer volume of martyrs, however, created a cluster of easily confused and nearly interchangeable narratives whether they were in martyrologies or in medieval hagiographical compilations such as the Legenda aurea ${ }^{501}$ For example, when comparing the variety of Flos sanctorum, there were an abundance of accounts on Eulalia of Barcelona and Eulalia of Meridia, both were often used interchangeably. Other examples included the lives of martyrs with 'Faust' in their name and the saturation of Felices. In our comparison of the contents of Villegas and Ribadeneyra's compilations, we can discern that the Jesuit was much more selective about the martyrs' lives they inserted.

${ }^{498}$ Palomo "Corregir letras," 60-69; idem, "Disciplina cristıana," 127-36

${ }^{499}$ For example, the Jesuits published a series of engravings based on the frescos of Santo Stefano Rotondo that featured the martyrs of the early church, such as Stephen, Ignatius of Antioch, and Catherine of Alexandra: see Norren

${ }^{500}$ Ribadeneyra, Flos (1599), sig ๆศ 6r, sig. ๆศๆ 1v "Vno de los mayores argumentos que tenemos los Christianos para confirmacion de nuestra santa religion, es, la de los bienauenturados, y fortissimos Martyres, que por ella dieron sus vidas Porque fueron inumerables hombres y mugeres, de todos estados, condiciones, edades, y naciones, y murieron con tan estraña y admırable constancia, que assombraron y vencieron al mundo, auiendo antes sido a tormentados con todos los generos de atrozissimos y exquisitos suplicios, que el demonio, y los tyranos sus ministros pudieron inuentar, y estos glonosos Caualleros de Christo los sufrieron con mas que humana pacie[n]cıa, fortaleza, y alegria . y á la santa Yglesia, que esta armada de vnesquadron de tan luzidos, y tan inuencibles soldados' y sin que nosotros nos corramos, y cubramos nuestro rostro de verguenca, viendo nuestra tibieza y floxedad; y que no bastan tan ilustres exemplos de virtud, $\mathrm{n}$ tan encendidas llamas de amor diuıno"

${ }^{501}$ This criticism has existed since the fifteenth-century amongst Italian humanists; the lives of martyrs that were not believeable were ill suited for imitation Moreover, if tangible relics could not be accurately placed, it also lessens the potential power of adoptıng the saint as exemplar. Frazier, 45-99. 
Martyrs' lives, however, revealed the subtleties of Catholic religious life, whether local or transnational. These texts illustrated the complex relationships between secular and spiritual rulers. For instance, the translation of Justus and Pastor's relics from Huesca to the boy-martyrs' birthplace of Alcalá in 1568 was an involved process. It required both a papal brief and an official order from Philip II depicting a negotiation of power between secular rulers and the papacy. As well, it revealed the city's willingness to maintain its collective past and to perpetuate the memory of relevant historical persona. ${ }^{502}$ Hagiographies about martyrs also illustrated the ongoing devotion to particular saints as intercessors. In the case of Sebastian, Christians called upon the saint to intercede and avert pestilence from ruining crops, indicating a continued practicality of saints in everyday lives. ${ }^{503}$ Also, Sebastian alone and in conjunction with George and Maurice were invoked as patron saints and defenders of the Roman or "universal" church against enemies of the faith. ${ }^{504}$ The hagiographies of martyr-saints were complex due to their dual perception as antiquated religious heroes and heroines as well as protectors of the faithful.

Ribadeneyra's life of Stephen, meanwhile, communicated a model of martyrdom based on both biblical and nonbiblical sources. Stephen was not only the first martyr of

${ }^{502}$ Ribadeneyra, Flos (1601), 151. "de donde el año de mil y quinientos y sesenta y ocho, co[n] breue del Papa Pio V y por mandado del Rey Catolico don Felipe II." On the relationship between the papacy and Philip II, consult: Ricardo García Carcel, "Las relaciones de la monarquía de Felipe II con la Compañía de Jesús," in Felipe II y el Mediterráneo, 4 vols., ed. Ernest Belenguer Cebrià, 2: 219-41 (Madrid: Sociedad Estatal para la Conmemoración de los Centenarios de Felipe II y Carlos V, 1999), especially 232-35.

${ }^{503}$ Ribadeneyra, Flos (1599), 225. "Tiene todo el pueblo Christiano mucha deuocion á este Santo, por los beneficios que por su intercession continuamente recibe de la mano del Señor, especialmente en tiempo de pestilencia, mostrandose piadoso á los que se le encomiendan y piden fauor."

${ }_{504}$ Ibid. 223, 225. "por orden del santo Pontifice Cayo, que á la sazon presidia en la Yglesia vniuersal...Entre los que quedaron fue San Sebastian, al qual dio San Cáyo Papa titulo de Defensor de la Fe, y es la primera vez que leemos auerse dado este tan glorioso titulo por la Sede Apostolica...Tambien es cosa antigua, que la Yglesia Romana inuoque el fauor del Señor contra los enemigos de la Fe, tomando por patrones á San Sebastian, á San Iorge, y á S[an] Mauricio" 
Christendom, but also "first in the list of the martyrs: because he was the first...that gave his life to Christ, and in faith, they dedicated and offered to the Lord the first fruits of the Martyrs, and Stephen, with his example, led the way to others." ${ }^{505}$ As other New Testament saints tend to do in the Flos, Stephen was portrayed as actively engaging in the imitation of Christ. ${ }^{506}$ In Ribadeneyra's conception of the early church, only the superlative exemplar (Christ) and other disciples would be imitated. Stephen's virtues might have died with him, but his martyrdom amplified his orthodox conduct: "patience and perseverance died with him as well as all the other most excellent virtues that we should seek to imitate. ${ }^{\text {507 }}$ Ribadeneyra created an ongoing succession of sancitified emulation through the recollection of Stephen.

In this examination of early modern saints, most were models for religious conduct, which in turn suggested a Catholic community assembled through re-enacting saintly behaviour. The ultimate exemplar was and continued to be Christ. The apostles followed the life of Christ and initiated a religious community based on it. Several types of saints based on individual apostles became the template for all subsequent imitation, which required the observation of the conduct of saints, whether through reading about them or witnessing their piety. Emulating the lives of saints was an assertion of a confessional Catholic identity in the late-sixteenth century, a cultural practice evident in

\footnotetext{
${ }^{505}$ Ribadeneyra, Flos (1601), 744. "por esso es llamado S[an] Esteuan Protomartyr, y primicerio de los Martyres: porq[ue] fue el primero...que dio la vida por Christo, y en el fe dedicaron, y se ofrecieron al Señor las primicias de los Martyres, y el con su exemplo abrió camino á los demas"

${ }_{506}$ Ibid. 743-44. "Imitando en esto al Señor de todo lo criado, que en la Cruz suplico al Padre eterno q[ue] perdonasse á los que le crucificauan: juzgando q[ue] hazia poco en seguir las pisadas de su Maestro, pues auia tan gran diferencia de su vida á la vida de Christo, y de muerte á muerte. Y es de creer, q[ue] el Señor oyó aquella oracion que salia de pecho tan encendido en su amor, y tan desseoso de imitarle: y que muchos de los que alliestauan, y le apedreaua[n], se conuirtieron, y alumbrados co[n] la luz del cielo recibieron la Fe de Christo, y murieron por ella."

${ }^{507}$ Ibid. 746. "la paciencia, y constancia con que murio, y todas las otras excelentissimas virtudes que nosotros deuemos procurar de imitar."
} 
the Society of Jesus. Changes to patterns of textual distribution accompanied this process. The circulation of saints' lives in manuscript had existed since Antiquity. What had changed was the mode of dissemination for hagiographies, which augmented extant networks with print media. 


\section{CONCLUSION}

While Christ remained the prime exemplar for Catholics, saints persisted as the paragons of confession-specific virtue. Apparent in Ribadeneyra's Flos sanctorum, sainthood began with the imitation of Christ, followed by the creation of cycles of sanctity forming an array of exceptional men and women. I used saintly archetypes cautiously due to the numerous emulations occurring simultaneously. To enter into the succession of sainthood, one had to observe Christian virtue. I believe that Ribadeneyra suggested two forms of observational emulation. The first involves direct sensory perception, such as when the apostles witnessed Christ's ministry and death. At the same time, texts provided access to religious observational emulation. Reading the lives of the deceased provided a parallel experience, which encouraged spiritual change. For example, Dominic and Francis of Assisi's entry into the religious life was facilitated by reading the life of Christ in the Gospels and the accounts of the Desert Fathers in Cassian's Conferences. Both of these approaches to the imitation of exemplars appeared in the lives Ribadeneyra devoted to doctors, apostles, martyrs, and founders studied in this thesis.

The practices of seeing exemplary conduct was evident amongst early modern

Jesuits. Francis Xavier's letters encouraged other Jesuits to become missionaries; meanwhile Ribadeneyra's life of Ignatius provided the pivotal virtues for every Jesuit. Texts became especially important after Xavier and Ignatius's deaths, since their exemplarly lives required observation through reading instead of simply seeing their conduct in person. The increased reliance on observational emulation through texts was also important in the Society's age of rapid expansion under Superior-General 
Acquaviva. The number of Jesuits made it impossible to observe exemplars in action. Other facets of visual cultures in the Society of Jesus appeared in its performance of religious drama, its commissioning of frescos depicting saints, and its highly ornate Baroque churches, especially the order's mother church in Rome, $I l$ Gesù.

Ribadeneyra's composition of hagiographies is one facet of the Society's heavily visual culture. I have found that the composition of saints' lives, however, also enabled Ribadeneyra to integrate the order into Catholicism considering the Jesuits relative recent appearance in early modern Christianity. Ribadeneyra achieved this objective by following the practices of Lippomano and Surius. In the midst of the Council of Trent, Lippomano started the practice of gathering sacred biographies from their sources. Surius continued Lippomano's project but amended the work and removed any superfluous lives. Ribadeneyra began to write his life of Ignatius at approximately the same time that Surius worked on his hagiographical compilation. He also read Surius and Lippomano. Surius and Lippomano used their hagiographies as a proclamation of their Catholicism and as a refutation of Protestant heresy, something that resonated with Ribadeneyra. In his Flos sanctorum, Ribadeneyra situated himself within the Lippomano-Surius tradition of hagiography to continue an authentic compilation of glorified Catholic exemplars.

In late-sixteenth century Spain, Ribadeneyra composed his Flos sanctorum in a place committed to the veneration of saints, to reading about their lives, and the refutation of any unorthodoxy. While Ribadeneyra continued Lippomano and Surius's hagiographical tradition, Ribadeneyra's Flos sanctorum augmented his predecessors by incorporating liturgical reforms into his saints' lives. Ribadeneyra adjusted his Flos sanctorum so that it corresponded with Catholic practices apparent in the Gregorian 
calendar, the Roman Breviary, and the Roman Martyrology. Ribadeneyra concentrated his efforts on the entirety of Catholicism. In the two decades after the publication of Ribadeneyra's Flos sanctorum in 1599, it appeared in French and Italian translations, traditional heartlands of early modern Catholicism. ${ }^{508}$ Villegas and Ribadeneyra also included the lives of extravagantes in their Flos sanctorum. In particular, Ribadeneyra used the extravagantes for the promotion of local cults, beatified figures, as well as Jesuit exemplars. Ribadeneyra situated the Society within early modern Catholicism by integrating his order into hagiographies, while also adapting the genre to conform to the observational emulation in use by Jesuits.

In the culture of reading saints' lives as a method of Catholic social discipline, Ribadeneyra's reading habits also legitimised his practices as a Catholic hagiographer. Early modern Catholicism emphasised a communal and universal history from the apostolic church to the present, a model that appeared in the Jesuit Canisius's Catechism. The community of Catholic readers built on Ribadeneyra's Flos sanctorum used the saints' lives for observational emulation and for tracing their history through ecclesiastical writers. For Ribadeneyra, Lippomano and Surius had initiated a new approach to hagiography, which he actively continued. Ribadeneyra also acknowledged the influence of other contemporary sacred historians, such as Caesar Baronius and his Annales ecclesiastici. I found that Ribadeneyra or a Flos's reader entered into a Catholic community through reading about the confession's tradition and legitimate connections with the apostolic church. As well, they participated and expressed this confessional identity through social discipline based on 'seeing' the lives of saints and then imitating them.

${ }^{508} B C J, 6: 1743-1754$ 
While the above findings are suggestive, more work is required. My first problem involves sources. While the increased digitization of texts has made sources more accessible, they are still gaps that archival work will lessen. Though incomplete, recently some of the original volumes of Surius's De probatis sanctorum have become available on Google Books, although too late for use here. I think additional consultation with the original editions of Lippomano and Surius's works would benefit my perceptions of their movement away from Voragine. At the same time, my work requires the increased study of the holdings in European libraries, such as Madrid's Biblioteca nacional de España and Archivo histórico, Paris's Bibliothèque nationale du France and Bibliothèque SainteGeneviève, as well as the Society's holdings in Rome. That said, my concerns are a future consideration and do not interfere with the findings of my study.

Any additional work on the Flos sanctorum has to encompass the entirety of its lives featured therein. While my selectivity covers countless themes in the history of early modern Catholicism, it excludes just as many. For instance, I think more can be made about the representations of women featured in these compilations of saints' lives. How did Ribadeneyra depict female saints? Did they conform to gender stereotypes? Was he different from other early modern hagiographers? As well, embedded within the compilation is a study of attitudes towards the early modern papacy through the accounts of sainted popes. While Catholics continued their commitment to the Roman church, how did Ribadeneyra portray the popes? Was there ambivalence towards the pontiff's authority? Also further comparative work is necessary on the extravagantes as well as Ribadeneyra's inclusion of Jesuits amongst them. 
Since Ribadeneyra's Flos sanctorum saw translation into French and Italian, a transnational comparison of the works in the seventeenth century would also hold much promise. Were the themes in Castilian depictions of Ribadeneyra's Flos sanctorum consistent in translations? Did these works become localised? Were saints' lives added, altered, or removed based on the locality? Analysing the Flos in this way would potentially illuminate the communication networks at play amongst Catholics in early modern Europe. The similarities in these hagiographies would indicate the 'universal' aspects of Catholicism, especially when compared with its localised components. In studying Catholic identity, I think that its variants and its continuities should take centrestage, especially through the Society of Jesus, which became by Superior-General Claudio Acquaviva's death in 1615, an international entity.

A discernible problem in the historiography is the apparent disappearance of Ribadeneyra's hagiographical work after the initial printings of the Bollandists' massive undertaking, the Acta sanctorum. The number of editions and translations of Ribadeneyra's Flos sanctorum reveal its continued popularity. Meanwhile the Bollandists' effort at collecting hagiographies and criticising their verity and their provenance spanned the seventeenth to the twentieth centuries, which survived even after the Society's suppression between 1767 and 1814. While largely ignored, Ribadeneyra's importence lies in being not only the Society's first hagiographer, but also as the writer of one of early modern Catholic Europe's most popular religious works. The popularity of his writings reveals the continued interest in saints amongst Catholics in early modern Europe. Even after the ascent of the Bollandists, Ribadeneyra remained popular in Spain into the mid-eighteenth century. The Dictionary of the Castilian Language, published in 
the eighteenth century, employs many of Ribadeneyra's works in its examples on vocabulary use, including his Flos sanctorum. ${ }^{509}$ While other confessions dismissed the miracles, relics, and intercessory nature of saints, Catholics through their reading of saints' lives remained devoted to these imitators of Christ by becoming witnesses to their example depicted on a page.

${ }^{509}$ Diccionario de la lengua castelleana, 3:6 [r. It used the Historia eclesiastica, his translations of Augustine's Confessions and Pseudo-Augustine's Soliloquies, the Flos sanctorum, and the Tratado de la tribulacion. 


\section{APPENDICES}

\section{APPENDIX 1: PRINTED FLOS SANCTORUM IN EARLY MODERN SPAIN}

\subsection{Flos before Lippomano and Surius}

Vorgaine, Jacobus de. La leyenda de los santos que vulgarmente flossantorum llaman. Burgos: Juan de Burgos, 1500. Fol. (IB 19699)

Flos sanctorum. Valencia: Jorge Costilla, 1514. $4^{\circ}$. (IB 8980)

Ocaña, Gonzalo de, [and Pedro de la Vega?]. La vida y passión de Nuestro Señor Jesucristo y las historias de las festividades de su Sanctissima Madre, con las de los santos apóstoles, mártires, confessores, y virgines. Zaragoza: Jorge Cocci, 1516. Fol. (IB 9725)

Flos sanctorum. Barcelona: Carles Amorós, 1519-20. Fol. (IB 8981)

Leyenda de los santos (que vulgarmente flossanctorum llaman) agora de nueva empremida. [Seville: Juan Valera de Salamanca, 1520-1]. Fol. (IB 8982 and 8983)

Vega, Pedro de la. Flos sanctorum. La vida de nuestro señor Jesu Cristo y de su Sanctíssima Madre, y de los santos, segun la orden de sus fiestas. [Zaragoza]: s.n., 1521. (IB 19220)

Flos sanctorum. Barcelona: Carles Amorós, 1524. 4. (IB 8984)

Vega, Pedro de la. La vida de nuestro señor Jesu Cristo y de su Sanctissima Madre, y de los santos, segun la orden de sus fiestas. [Zaragoza: Jorge Cocci,] 1527. (IB 19221)

Vega, Pedro de la. La vida de nuestro señor Jesu Cristo y de su Sanctíssima Madre, y de los santos, segun la orden de sus fiestas. Zaragoza: Jorge Cocci, 1533. (IB 19223)

Vega, Pedro de la. Libro que es llamado Vida de Jesu Christo y de sus sanctos. Seville: Juan Cromberger, 1540. Fol. (IB 19229)

Vega, Pedro de la. Flos sanctorum. La vida de nuestro señor Jesu Cristo y de su Sanctíssima Madre, y de los santos, segun la orden de sus fiestas. Alcalá de Henares: s.n., 1541. (IB 19230)

Vega, Pedro de la. La vida de Nuestro Señor Jesucristo y de su Sanctíssima Madre, y de los otros santos, segun la orden de sus fiestas. Rev. Pedro de la Vega. Zaragoza: Jorge Cocci, Pedro Bernuz, and Bartolomé de Nájera, 1541. (IB 19231) 
Vega, Pedro de la. La vida de Nuestro Señor Jesucristo y de su Sanctíssima Madre, y de los otros santos, segun la orden de sus fiestas. Rev. Pedro de la Vega. Zaragoza: Jorge Cocci, 1544. Fol. (IB 19232)

Vega, Pedro de la. Flos sanctorum. La vida de Nuestro Señor Jesucristo y de su Sanctissima Madre, y de los otros santos. Rev. Pedro de la Vega. [Alcalá de Henares]: Juan de Brocar, 1545. Fol. (IB 19233)

Flos sanctorum. Barcelona: Carles Amorós, 1547. 4 . (IB 8986)

Vega, Pedro de la. Flos sanctorum. La vida de Nuestro Señor Jesucristo y de su Sanctíssima Madre, y de los otros santos, segun la orden de sus fiestas. Rev. Pedro de la Vega. Zaragoza: Bartolomé de Nájera, 1548. Fol. (IB 19234)

Vega, Pedro de la. La vida de Nuestro Señor Jesucristo y de su Sanctíssima Madre, y de los otros santos, segun la orden de sus fiestas. Rev. Pedro de la Vega. Zaragoza: Bartolomé de Nájera, 1551. Fol. (IB 19235)

Leyenda de los santos que vulgarmente flossantorum llaman. Zaragoza: Pedro Bernuz, 1551. Fol. (IB 8988)

Vega, Pedro de la. La vida de Nuestro Señor Jesucristo y de su Sanctíssima Madre, y de los otros santos, segun la orden de sus fiestas. Rev. Pedro de la Vega. Zaragoza: Bartolomé de Nájera, 1554. Fol. (IB 19236)

Leyenda de los santos que vulgarmente flossantorum llaman. Toledo: Juan Ferrer, 1554. (IB 8989)

Vega, Pedro de la. Flos sanctorum. La vida de Nuestro Señor Jesucristo y de su Sanctíssima Madre, y de los otros santos. Rev. Martín de Lillio. Alcalá de Henares: Juan de Brocar, 1558. Fol. (IB 19237)

Vega, Pedro de la. Flos sanctorum. La vida de Nuestro Señor Jesucristo y de su Sanctíssima Madre, y de los otros santos. Rev. Martín de Lillio. Alcalá de Henares: Andrés de Angulo, 1566. Fol. (IB 19238)

Leyenda de los santos que vulgarmente flossantorum llaman. Rev. Doctor Corrasco. Alcalá de Henares: [Sebastián Martínez], 1567. Fol. (IB 8991)

Flos sanctorum. Seville: Juan Gutiérrez, 1568. Fol. (IB 8992)

Flos sanctorum. Seville: s.n., 1569. Fol. (IB 8993)

Vega, Pedro de la. Flos sanctorum. La vida de Nuestro Señor Jesucristo y de su Sanctíssima Madre, y de los otros santos. Rev. Martín de Lillio. Alcalá de Henares: Andrés de Angulo, 1572. Fol. (IB 19239) 
Vega, Pedro de la. Flos sanctorum. La vida de Nuestro Señor Jesucristo y de su Sanctíssima Madre, y de los otros santos. Rev. Gonzalo Millán y Mora. Seville: Juan Gutiérrez, 1572. Fol. (IB 19240)

Flos sanctorum. Barcelona: Jaime Cendrat and the Widow of Pere Montpesat, 1575.Fol. (IB 8994)

Vega, Pedro de la. Flos sanctorum General. La vida de Nuestro Señor Jesucristo y de su Sanctíssima Madre, y de los otros santos. Rev. Juan Sánchez and Pedro de Leguizamo. Medina del Campo: Francisco del Canto, 1578. Fol. (IB 19241)

Vega, Pedro de la. Flos sanctorum y leyenda de los sanctos. Seville: Alonso de la Barrera and Pedro de Pineda, 1579. (IB 19242)

Vega, Pedro de la. Flos sanctorum General. La vida de Nuestro Señor Jesucristo y de su Sanctíssima Madre, y de los otros santos. Rev. Francisco Pacheco. Seville: Francisco Díaz, [1580]. (IB 19243)

\subsection{Flos influenced by Lippomano and Surius}

Villegas y Selvago, Alonso de. Flos Sanctorum Nuevo, y Historia General de la Vida de Christo Señor Nuestro y de todos de los santos que reza y hace fiesta la Iglesia Católica. Zaragoza: Domingo de Portonariis, 1580. Fol. (IB 19546)

Villegas y Selvago, Alonso de. Flos sanctorum y historia general de la vida y hechos de Jesu Christo y de todos los sanctos de que reza y hace fiesta la iglesia católica, conforme al brevario romano. Toledo: Juan Rodríguez, 1582. Fol. (IB 19547)

Villegas y Selvago, Alonso de. Flos sanctorum y historia general, de la vida y hechos de Jesu Christo, quitadas algunas cosas aopcriphas y inciertas. Dirigido al rey nuestro señor don Philippe segundo deste nombre. Toledo: Juan Rodríguez, 1582. Fol. (IB 19548)

Villegas y Selvago, Alonso de. Flos sanctorum y historia general de la vida y hechos de Jesu Christo y de todos los sanctos de que reza y hace fiesta la iglesia católica. Zaragoza: Juan Soler, 1583. Fol. (IB 15549)

Villegas y Selvago, Alonso de. Flos sanctorum y historia general de la vida y hechos de Jesu Christo y de todos los sanctos de que reza y hace fiesta la iglesia católica, conforme al brevario romano. Toledo: Juan Rodríguez, 1583. Fol. (IB 19550)

Villegas y Selvago, Alonso de. Flos sanctorum, tercera parte. Toledo: Juan Rodríguez and Pedro Rodríguez, 1583. $8^{\circ}$. (IB 19551)

Villegas y Selvago, Alonso de. Flos sanctorum. [Toledo:] s.n., [1583]. Fol. (IB 19552) 
Villegas y Selvago, Alonso de. Flos sanctorum. Toledo: Juan Rodríguez, 1584. Fol. (IB 19553)

Villegas y Selvago, Alonso de. Flos sanctorum. Zaragoza: Simón de Portonariis, 1585. Fol. (IB 19554)

Villegas y Selvago, Alonso de. Flos sanctorum, vida y hechos de Jesu Christo. Barcelona: Damián Bages, 1586. (IB 19555)

Villegas y Selvago, Alonso de. Flos sanctorum, segunda parte y historia general. Zaragoza: Simón de Portonariis, 1586. Fol. (IB 19556)

Villegas y Selvago, Alonso de. Flos sanctorum segunda parte, y historia general en que se escribe la vida de la virgen y las de los sanctos antiguos. Toledo: Juan Rodríguez, 1586. (IB 19557)

Villegas y Selvago, Alonso de. Flos sanctorum. Barcelona: Francisco Trinxer, 1586. Fol. (IB 19558)

Villegas y Selvago, Alonso de. Flos sanctorum, segunda parte y historia general en que se escribe la vida de la virgen, y la de los sanctos antiguos, que fueron antes de la venida de muestro salvador. Barcelona: Juan Pablo Menescal, 1586. Fol. (IB 19559)

Villegas y Selvago, Alonso de. Flos sanctorum y historia general, de la vida y hechos de Jesu Christo, Dios y señor nuestro, y de todos los santos de que reza y haze fiesta la iglesia catholica confrome al brevario romano, reformado por decreto del sacto concilio Tridentino, junto con las vidas de los sanctos proprios de Espana, y de otros extravagantes. Toledo: Juan Rodríguez, 1587. (IB 19560)

Villegas y Selvago, Alonso de. Flos sanctorum. Barcelona: Hubert Gotard. 1587. Fol. (IB 19561 and 19562)

Villegas y Selvago, Alonso de. Flos sanctorum. Segunda parte. Zaragoza: Lorenzo de Robles and Diego de Robles, 1587. Fol. (IB 19563)

Villegas y Selvago, Alonso de. Addicion a la tercera parte del flos sanctorum. Barcelona: Jerónimo Genovés, 1588. Fol.(IB 19564)

Villegas y Selvago, Alonso de. Addicion a la tercera parte del flos sanctorum. Huesca: Juan Pérez de Valdivielso, Juan de la Cuesta and Gil Martínez Fanés, 1588. Fol. (IB 19565)

Villegas y Selvago, Alonso de. Addicion a la tercera parte del flos sanctorum. Toledo: Juan Rodríguez and Pedro Rodríguez, 1588. Fol. (IB 19566) 
Villegas y Selvago, Alonso de. Flos sanctorum nuevo, y historia general de la vida de Jesu Christo, Dios, y señor nuestro y de todos de los sanctos que reza, y hace fiesta la yglesia catholica. Venice: Félix Valgrisio and Angelo Tavano, 1588. (IB 19567)

Villegas y Selvago, Alonso de. Flos sanctorum y historia general de la vida y hechos de Jesu Christo. Barcelona: Hubert Gotard, 1588. Fol. (IB 19568)

Villegas y Selvago, Alonso de. Flos sanctorum y historia general, de la vida y hechos de Jesu Christo, Dios y señor nuestro, y de todos los santos de que reza y haze fiesta la iglesia catholica confrome al brevario romano, reformado por decreto del sancto concilio Tridentino, junto con las vidas de los sanctos proprios de Espana, $y$ de otros extravagantes. Madrid: Pedro Madrigal, 1588. Fol. (IB 19569)

Villegas y Selvago, Alonso de. Flos sanctorum, tercera parte. Barcelona: Damián Bages and Jerónimo Genovés, 1588. Fol. (IB 19570)

Villegas y Selvago, Alonso de. Flos sanctorum, tercera parte. Barcelona: Jerónimo Genovés and Jaime Cendrat, 1588. Fol. (IB 19571)

Villegas y Selvago, Alonso de. Flos sanctorum, tercera parte. Zaragoza: Pedro Puig and Juan de Escarrilla, 1588. Fol. (IB 19572)

Villegas y Selvago, Alonso de. Flos sanctorum. Toledo: Juan Rodríguez, 1588. Fol. (IB 19573)

Villegas y Selvago, Alonso de. Flos sanctorum. Zaragoza: Lorenzo de Robles y Diego de Robles, 1588. Fol. (IB 19574)

Villegas y Selvago, Alonso de. Flos sanctorum. Zaragoza: Pedro Puig, 1588. Fol. (IB 19575)

Villegas y Selvago, Alonso de. Flos sanctorum y historia general, de la vida y hechos de Jesu Christo, Dios y señor nuestro, y de todos los santos de que reza y haze fiesta la iglesia catholica confrome al brevario romano, reformado por decreto del sacto concilio Tridentino, junto con las vidas de los sanctos proprios de Espana, $y$ de otros extravagantes. Zaragoza: Lorenzo de Robles and Diego de Robles, 1588. Fol. (IB 19576)

Villegas y Selvago, Alonso de. Flos sanctorum quarta y ultimate parte. Madrid: Pedro Madrigal, 1589. Fol. (BM 318; IB 19577)

Villegas y Selvago, Alonso de. Flos sanctorum [segunda parte]. Barcelona: Pedro Gotard, $1589.8^{\circ}$. (IB 19578) 
Villegas y Selvago, Alonso de. Flos sanctorum, segunda parte. Toledo: Juan Rodríguez, 1589. Fol. (IB 19579)

Villegas y Selvago, Alonso de. Flos sanctorum, tercera parte. Toledo: Juan Rodríguez y Pedro Rodríguez, 1589. Fol. (IB 19580)

Villegas y Selvago, Alonso de. Flos sanctorum. Barcelona: Arnau Garrich, 1589. Fol. (IB 19581)

Villegas y Selvago, Alonso de. Flos sanctorum, quarta y ultima parte y discursos o sermones sobre los evangelios de todas las dominicas del año, ferias de quaresma $y$ de sanctos principales. Barcelona: Widow of Goetard-Sebastian Cormellas, 1590. Fol. (IB 19582)

Villegas y Selvago, Alonso de. Flos sanctorum, quarta y ultima parte y discursos o sermones sobre los evangelios de todas las dominicas del año, ferias de quaresma $y$ de sanctos principales. Barcelona: Widow of Jaime Cendrat, 1590. Fol. (IB 19583)

Villegas y Selvago, Alonso de. Flos sanctorum, quarta y ultima parte y discursos o sermones sobre los evangelios de todas las dominicas del año, ferias de quaresma $y$ de sanctos principales. Barcelona: Widow of Hubert Gotard, 1590. Fol. (IB 19584)

Villegas y Selvago, Alonso de. Flos sanctorum. Barcelona: Widow of Hubert Gotard, 1590. Fol. (IB 19585)

Villegas y Selvago, Alonso de. Flos sanctorum y historia general, de la vida y hechos de Jesu Christo, Dios y señor nuestro, y de todos los santos de que reza y haze fiesta la iglesia catholica confrome al brevario romano, reformado por decreto del sacto concilio Tridentino, junto con las vidas de los sanctos proprios de Espana, $y$ de otros extravagantes. Toledo: Widow of Juan Rodríguez, 1591. Fol. (IB 19588)

Villegas y Selvago, Alonso de. Flos sanctorum, tercera parte y historia general en que se escriben las vidas de sanctos extravagantes. Zaragoza: Lorenzo de Robles, 1591. Fol. (IB 19589)

Villegas y Selvago, Alonso de. Flos sanctorum. Madrid: Pedro Madrigal, 1592. Fol. (IB 19590)

Villegas y Selvago, Alonso de. Flos sanctorum, quarta y ultima parte y discursos o sermones sobre los evangelios de todas las dominicas del año, ferias de quaresma $y$ de sanctos principales. Barcelona: Noel Baresson, 1593. Fol. (IB 19592) 
Villegas y Selvago, Alonso de. Flos sanctorum y historia general, de la vida y hechos de Jesu Christo, Dios y señor nuestro, y de todos los santos de que reza y haze fiesta la iglesia catholica confrome al brevario romano, reformado por decreto del sacto concilio Tridentino, junto con las vidas de los sanctos proprios de Espana, $y$ de otros extravagantes. Barcelona: Sebastián de Cormellas, 1593. Fol. (IB 19593)

Villegas y Selvago, Alonso de. Flos sanctorum. Madrid: Pedro Madrigal, 1593. Fol. (IB 19594)

Villegas y Selvago, Alonso de. Flos sanctorum, quarta y ultima parte y discursos o sermones sobre los evangelios de todas las dominicas del año, ferias de quaresma $y$ de sanctos principales. Cuenca: Juan Masselin, 1593. Fol. (BM 423 and 424; IB 19596)

Villegas y Selvago, Alonso de. Flos sanctorum segunda parte, y historia general en que se escribe la vida de la virgen y las de los sanctos antiguos. Toledo: Juan Jaure, 1594. Fol. (IB 19598)

Villegas y Selvago, Alonso de. Flos sanctorum y historia general, de la vida y de hechos de Jesu Christo, y de todos los santos. Madrid: Pedro Madrigal, 1594. Fol. Lost. (BM 460; IB 19599)

Villegas y Selvago, Alonso de. Flos sanctorum. Barcelona: Pablo Malo, 1594. Fol. (IB 19600)

Villegas y Selvago, Alonso de. Fructus sanctorum y quinta parte de flos sanctorum, que es libro de exemplos, assi de hombres illustres en sanctidad, como de otros cuyos hechos fueron dignos de reprehension y castigo. Barcelona: Sebastián de Cormellas, 1594. Fol. (IB 19601)

Villegas y Selvago, Alonso de. Fructus sanctorum y quinta parte de flos sanctorum. Cuenca: Juan Masselin, 1594. Fol. (IB 19602)

Villegas y Selvago, Alonso de. Fructus sanctorum y quinta parte de flos sanctorum. Cuenca: Juan Masselin and Christiano Bernabé, 1594. Fol. (IB 19603)

Villegas y Selvago, Alonso de. Fructus sanctorum y quinta parte de flos sanctorum. Zaragoza: Lorenzo de Robles, 1594. Fol. (IB 19604)

Villegas y Selvago, Alonso de. Flos sanctorum, tercera parte. Toledo: Pedro Rodríguez, 1595. Fol. (IB 19605)

Villegas y Selvago, Alonso de. Flos sanctorum, quarta y ultima parte y discursos o sermones sobre los evangelios de todas las dominicas del año, ferias de quaresma 
$y$ de sanctos principales. Cuenca: Miguel Serrano de Vargas, 1599. Fol. (IB 19608)

Ribadeneyra, Pedro de. Flos sanctorum o libro de las vidas de los santos. Madrid: Luis Sánchez, 1599. Fol. (BM 646; IB 15877)

Villegas y Selvago, Alonso de. Flos sanctorum segunda parte y historia general en que se escribe la vida de la virgen. Barcelona: Juan Amello, 1600. Fol. (IB 19609)

Ribadeneyra, Pedro de. Segunda parte del Flos sanctorum, o libros de las Vidas de los Santos. En la qual se contienen las vidas de todos los Santos que reza la Iglesia Romana en los seys postreros meses del Año. Madrid: Luis Sánchez, 1601. Fol. (BM 791; JS 1548)

Villegas y Selvago, Alonso de. Flos sanctorum y historia general, de la vida y hechos de Jesu Christo, Dios y señor nuestro, y de todos los santos de que reza y haze fiesta la iglesia catholica confrome al brevario romano, reformado por decreto del sacto concilio Tridentino, junto con las vidas de los sanctos proprios de Espana, $y$ de otros extravagantes. Barcelona: [Sebastián de Cormellas], 1602. Fol. (Housed at the Bibliothèque Saint-Geneviève, Paris)

Villegas y Selvago, Alonso de. Flos sanctorum, quarta y ultima parte y discursos o sermones sobre los evangelios de todas las dominicas del año, ferias de quaresma $y$ de sanctos principales. Barcelona: Jaime Cendrat, 1603. Fol. (Housed at the Biblioteca de Catalunya, Barcelona)

Villegas y Selvago, Alonso de. Frvctvs Sanctorum, y qvinta parte de Flos Sanctorum. Cuenca: Luis Cano, 1604. Fol. (Housed at the Biblioteca Nacional de España, Madrid)

Ribadeneyra, Pedro de. Libro de Vidas de Santos, que communmente llaman Extravagantes; porque la santa Yglesia no reza dellos en el Breviario Romano. Madrid: Luis Sánchez, 1604. Fol. (BM 888; JS 1549)

Ribadeneyra, Pedro de. Segunda parte del Flos Sanctorum, o Libro de las Vidas de los Santos. En la qual se contienen las Vidas de muchos Santos de todos estados, que communmente llaman Extrauagantes. Madrid: Luis Sánchez, 1609. Fol. (BM $1068 ;$ IS 1550)

Villegas y Selvago, Alonso de. Flos Sanctorum: segunda parte: $y$ historia general en que se escrive la vida de la Virgen Sacratissima Madre de Dios, y Señora Nuestra y las de los santos antiguos que fueron antes de la venida de nuestro salvador al mundo. Alcalá de Henares: Andrés Sánchez de Ezpeleta [inside it lists the Widow of Justo Sánchez Crespo], 1609. Fol. (Julián Martín Abad, La imprenta en Alcalá de Henares (1601-1700), 116) 
Villegas y Selvago, Alonso de. Flos sanctorum. Segunda parte: Vida de Nuestra Senora $y$ de los Santos antiguos del Testamento Viejo. Toledo: s.n., 1609. Fol. (Cristóbal Pérez Pastor, La imprenta en Toledo, 466)

Ribadeneyra, Pedro de. Flos sanctorum o libro de las vidas de los santos. Madrid: Luis Sánchez, 1610. Fol. (BM 1114; JS 1541) 


\section{APPENDIX 2: PRINTED WORKS OF PEDRO DE RIBADENEYRA}

Vita Ignatii Loiolae Societatis Iesu fundatoris, libris quinque comprehensa. Naples: Giuseppe Cacchius, $1572.16^{\circ}$. (Gilmont, Écrits, 7)

Vida del padre Ignacio de Loyola fundador de la compañia de Jesus. Madrid: Alonso Gómez, 1583. 4. (BM 191; IB 15842)

Vida del padre Ignacio de Loyola de la compañia de Jesus. Madrid: Widow of Alonso Gómez, 1584. 8 . (BM 211; IB 15843)

Vida del padre Ignacio de Loyola fundador de la compañia de Jesus. Madrid: Widow of Alonso Gómez, 1586. $8^{\circ}$. (BM 246; IB 15844)

Vita Ignatii Loiolae qui religionem clericorum societatis Iesu institut.Madrid: Widow of Alonso Gómez, 1586. $8^{\circ}$. (BM 247; IB 15845)

Vita Ignatii Loiolae qui religionem clericorum societatis Iesu institut.Antwerp: Christophe Plantin, 1587. 16. (BCJ, vol. 6, 1726)

Historia ecclesiastica del scisma del reyno de Ingleterra. Antwerp: Christophe Plantin, $1588.8^{\circ}$. (IB 15846)

Historia ecclesiastica del scisma del reyno de Ingleterra. Barcelona: Jerónimo Genovés and Jaime Cendrat, 1588. $8^{\circ}$. (IB 15847)

Historia ecclesiastica del scisma del reyno de Ingleterra. Madrid: Pedro Madrigal, 1588. $8^{\circ}$. (BM 289 and 290; IB 15848 and 15849; TM 394 and 395)

Historia ecclesiastica del scisma del reyno de Ingleterra. Valencia: Pedro Patricio Mey, $1588.8^{\circ}$. (IB 15850)

Historia ecclesiastica del scisma del reyno de Ingleterra. Zaragoza: Pedro Puig and Widow of Juan de Escarrilla, 1588. $8^{\circ}$. (IB 15851)

Hystoria ecclesiastica del scisma del reyno de Inglaterra, en la qual se tartan las cosas mas notables que han sucedido en quell reyno tocantes a nuestra santa religion, desde que començo hasta la muerte de la reyna de Escocia. Lisbon: Antonio Álvares, $1588.8^{\circ}$. (IB 15852)

Historia ecclesiastica del scisma del reyno de Ingleterra. Madrid: Widow of Alonso Gómez, 1589. 8. (IB 15853; TM 422)

Hystoria ecclesiastica del scisma del reyno de Inglaterra, en la qual se tartan las cosas mas notables que han sucedido en quell reyno tocantes a nuestra santa religion, 
desde que començo hasta la muerte de la reyna de Escocia. [Lisbon:] Manuel de Lira, 1589. $8^{\circ}$. (IB 15854)

Tratado de la tribulacion. Madrid: Pedro Madrigal, 1589. $8^{\circ}$. (BM 315; IB 15855; TM 423)

Vita Ignatii Loiolae qui religionem clericorum societatis Iesu institut. Ingolstadt: David Sartorius, $1590.8^{\circ}$. (BCJ, vol. 6, 1726)

Vita Ignatii Loiolae qui religionem clericorum societatis Iesu institut. Lyon: Jean Gesselin, 1590. 16². (BCJ, vol. 6, 1726)

Tratado de la tribulacion. Barcelona: Jaime Cendrat, $1591.8^{\circ}$. (IB 15856)

Vida del padre Francisco de Borja, que fue duque de Gandia y despues religioso y tercero general de la compañia de Jesus. Madrid: Pedro Madrigal, 1592. $4^{\circ}$. (BM 394; IB 15857; TM 534)

Segunda parte de la historia ecclesiastica del scisma del reyno de Ingleterra. Alcalá de Henares: Juan Íñiguez de Lequerica, 1593. $8^{\circ}$. (IB 15858)

Tratado de la tribulacion. Alcalá de Henares: Juan Íñiguez de Lequerica, 1593. $8^{\circ}$. (IB 15859)

Vida del padre Ignacio de Loyola, fundador de la religion de la compañia de Jesus y de los padres maestro Diego Laynez, y Francisco de Borja. En las quales se continene su fundacion, progresso, y aumento, hasta el año de 1572.Madrid: Pedro Madrigal, 1593-4. Fol. (BM 457; IB 15860; TM 564)

Albert the Great.Tratado de las virtudes intitulado parayso del alma. Trans. Pedro de Ribadeneyra. Madrid: Pedro Madrigal, 1593. 16². (IB 213)

Pseudo-Augustine. Libros de las meditaciones y soliloquios y manual. Trans. Pedro de Ribadeneyra. Madrid: Widow of Pedro Madrigal, 1594. 16². (BM 426; IB 1364; TM 569)

Historia ecclesiastica del scisma del reyno de Ingleterra. Segunda parte de la historia ecclesiastica. Antwerp: Martin Nutius, $1594.1^{\circ}$ (IB 15862)

Segunda parte de la historia ecclesiastica del scisma del reyno de Ingleterra. Lisbon: Manuel de Lira, 1594. $8^{\circ}$. (IB 15863)

Tratado de la religion y virtudes que deve tener el principe christiano, para governor y conserver sus estados. Contra lo que Nicolas Machiavelo y los politicos deste tiempo ensenan. Antwerp: Widow of Christophe Plantin, 1594. $8^{\circ}$. (IB 15864) 
Vida del p.m. Diego Laynez que fve uno de los companeros del padre maestro Ignacio de Loyola en fundar la compania de Jesus y el Segundo preposito general della. Madrid: Widow of Pedro Madrigal, 1594. (IB 15865)

Vida del padre Francisco de Boria, que fue duque de Gandia, y despues religioso, y tercero general de la compañia de Jesus y de los padres. Madrid: Widow of Pedro Madrigal, 1594. (IB 15866)

Vida del padre Ignacio de Loyola, fundador de la compañia de Jesus y de los padres maestros Diego Laynez, y Francisco Borja. Madrid: Pedro Madrigal, 1594. Fol. (IB 15867; TM 618)

Historia ecclesiastica del scisma del reyno de Ingleterra. Madrid: Widow of Pedro Madrigal, 1595. (IB 15868)

Lasobras. Madrid: Widow of Pedro Madrigal, 1595. Fol. (BM 496; IB 15869; TM 672)

Tratado de la religion y virtudes que deve tener el principe christiano, para governor $y$ conserver sus estados. Madrid: Pedro II Madrigal, 1595. 4. (BM 497; IB 15870; TM 673)

Albertus Magnus, santo. Augustine, santo. Tratado de la tribulacion repartido en dos libros, en el primero se trata de las tribulaciones particulars y en el segundo de las generals que Dios nos embia y del remedio dellas. Madrid: Widow of Pedro Madrigal, 1595. (IB 15872)

Vita Ignatii Loiolae qui religionem clericorum societatis Iesu institut. Madrid: Pedro Madrigal, $1595.8^{\circ}$. (BM 498; TM 674)

Augustine. Las confessions del glorioso dotor de la iglesia san Augustin. Trans. Pedro de Ribadeneyra. Madrid: Juan de Montoya, 1596. 16². (BM 502; IB 1366; JS 1530; TM 678)

El libro quinto de la vida del padre Ygnacio de Loyola. Madrid: Juan Flamenco, 1596. $16^{\circ}$. (BM 524; IB 15874; TM 712)

Vidas del P. Ignacio de Loyola, P. Diego Laynez y P. Francisco de Borja. Madrid: Imprenta Real, 1596. 12. (BM 525; TM 713)

Pseudo-Augustine. Libros de las meditaciones y soliloquios y manualdel glorioso doctor de la iglesia san Agustin. Trans. Pedro de Ribadeneyra. Madrid: Luis Sánchez, 1597. (BM 556; IB 1367)

Tratado de la religion y virtudes que deue tener el principe christiano, para governor y conserver sus estados. Antwerp: Plantin House and Juan Moreto, 1597. $8^{\circ}$. (IB 15876) 
Flos sanctorum o libro de las vidas de los santos. Madrid: Luis Sánchez, 1599. Fol. (BM 646; IB 15877; TM 877)

Segunda parte del Flos sanctorum, o libros de las Vidas de los Santos. En la qual se contienen las vidas de todos los Santos que reza la Iglesia Romana en los seys postreros meses del Año. Madrid: Luis Sánchez, 1601. Fol. (BM 791; JS 1548)

Tratado de la Religion y virtudes que deve tener el Principe Christiano, para gouernar y conseruar sus estados. Contra lo que Nicolas Machiauelo y los Politicos deste tiempo enseñan. Madrid: Luis Sánchez, 1601. (BM 792; JS 1528)

Libro de Vidas de Santos, que communmente llaman Extravagantes; porque la santa Yglesia no reza dellos en el Breviario Romano. Madrid: Luis Sánchez, 1604. Fol. (BM 888; JS 1549)

Vida de Christo y de su Madre Santissima. Madrid: Luis Sánchez, 1604. Fol. (BM 889)

Obras del Padre Pedro de Ribadeneyra. Agora de nueuo reuistas y acrecentadas. Madrid: Luis Sánchez, 1605. Fol. (BM 919; JS 1495)

Tratado, en el qual se da razon del institvto de la Religion de la Compañia de Iesvs. Madrid: College of the Society of Jesus, $1605.4^{\circ}$. (BM 920; JS 1554)

Manval de Oraciones, para el vso y aprouechamiento de la gente deuota. Madrid: Luis Sánchez, 1607. 16². (BM 977)

Augustine. Las confessions del glorioso Dotor de la Iglesia San Agvstin. Trans. Pedro de Ribadeneyra. Valencia: Juan Chrysostomo Garriz, 1608. 16². (JS 1531)

Illustrium scriptorum religionis Societatis Iesv catalogus. Antwerp: Plantin House and Juan Moreto, 1608. $8^{\circ}$. (JS 1568)

Illustrium scriptorum religionis Societatis Iesv catalogus. Lyon: Jean Pillehotte, 1609. $8^{\circ}$. (JS 1569)

Relacion de lo que ha svcedido en el negocio de la Canonizacion del bienauenturado P. Ignacio de Loyola, fundador de la Religion de la Compañia de Iesvs. Madrid: Luis Sánchez, 1609. $8^{\circ}$. (BM 1067)

Segunda parte del Flos Sanctorum, o Libro de las Vidas de los Santos. En la qual se contienen las Vidas de muchos Santos de todos estados, que communmente llaman Extrauagantes. Madrid: Luis Sánchez, 1609. Fol. (BM 1068; JS 1550)

Flos sanctorum, o libro de las vidas de los santos. Madrid: Luis Sánchez, 1610. Fol. (BM 1114; JS 1541) 
Manual de oraciones, para el uso y aprovechamiento de la gente devote. Madrid: P. Lisao [but with Juan Flamenco's colophon], 1611. 16². (BM 1155; JS 1562) 


\section{APPENDIX 3: BOOKS PRINTED BY THE MADRIGAL PRINT HOUSE OF MADRID}

\begin{tabular}{|c|c|c|c|c|c|}
\hline \\
\hline \multicolumn{2}{|c|}{ Annual Production } & \multicolumn{2}{|c|}{ Format Production } & \multicolumn{2}{|c|}{ Linguistic Production } \\
\hline Year & Amount & Size & Amount Produced & Language & Amount \\
\hline 1586 & 5 & Folio & 67 & Castilian & 142 \\
\hline 1587 & 14 & Quarto & 50 & Latin & 42 \\
\hline 1588 & 7 & Octavo & 54 & & \\
\hline 1589 & 10 & Duodecimo & 6 & & \\
\hline 1590 & 25 & Sextodecimo & 5 & &. \\
\hline 1591 & 14 & \multirow{2}{*}{\multicolumn{2}{|c|}{ Ordinal Production }} & & \\
\hline 1592 & 16 & & & \multicolumn{2}{|c|}{ Stylistic Production } \\
\hline 1593 & 13 & Order & Number of Writers & Type of Work & Amount \\
\hline 1594 & 5 & Jesuits & 13 & Ecclesiastic & 27 \\
\hline 1595 & 5 & Dominicans & 7 & Devotional & 54 \\
\hline 1596 & 8 & Franciscans & 4 & Philosophical & 7 \\
\hline 1597 & 6 & Minims & 2 & Utilitarian & 73 \\
\hline 1598 & 12 & Benedictines & 2 & Classics & 2 \\
\hline 1599 & 12 & Augustinians & 2 & Entertainment & 6 \\
\hline 1600 & 14 & Carmelites & 1 & Secular Histories & 15 \\
\hline 1601 & 3 & D.Carmelites & 1 & & \\
\hline 1602 & 5 & Merceds & 1 & & \\
\hline 1603 & 7 & Carthusians & 1 & & \\
\hline 1604 & 3 & Cistericians & 1 & & \\
\hline s.a. & 1 & & & & \\
\hline Total & 189 & & & & \\
\hline
\end{tabular}

Ogea, Diego de. O.P. Recopilación de las cosas tocantes a la devoción del Rosario de nuestra Señora. Madrid: Pedro Madrigal, s.a.. Fol. (TM 976) ${ }^{510}$

\subsection{Pedro Madrigal Period: 1586-1594}

Advertencias que dan los Católicos Ingleses, á los Católicos de Francia del peligro en que están de perder la Religión, si admiten á la corona Príncipe herege. Madrid: Pedro Madrigal, 1592. $8^{\circ}$. (TM 510)

Capítulos generales de las Cortes de Madrid, que se començaron el Año de mil y quinientos y ochenta $y$ tres, $y$ se fenecieron el de ochenta y cinco. Madrid: Pedro Madrigal, 1587. Fol. (TM 350)

Capítulos generales de las Cortes del año ochenta y seys, fenecidas y publicadas en el de noventa. Madrid: Pedro Madrigal, 1590. Fol. (TM 436)

${ }^{510}$ I have placed this entry here due to its lack of an identifiable year. 
Capitulos generales de las Cortes del año de mil quinientos y ochenta y ocho. Madrid: Pedro Madrigal, 1593. Fol. (TM 545)

Concilium Limense. Celebratum anno 1583 sub Greogrio XIII. Madrid: Pedro Madrigal, 1591. $4^{\circ}$. (TM 480)

Demanda y oposición de don Baltasar Colombo de Cucaro, para la cesión que pretende del mayorazgo que fundó D. Christóbal, primer Almirante de las Indias. Madrid: Pedro Madrigal, 1590. Fol. (TM 441)

Haec sunt acta capitulo generalis Romae celebrati in conventu Sanctae Mariae super Minervam. Madrid: Pedro Madrigal, 1590. $4^{\circ}$. (TM 446)

Ley y Premática, en que se da orden sobre la conservación y aumento de los Pósitos, y distribución del pan dellos. Madrid: Pedro Madrigal, 1590. Fol. (TM 449)

Libro de las leyes, privilegios, y provisiones reales del honrado Concejo General de la Mesta, y cabaña Real destos Reynos. Madrid: Pedro Madrigal, 1590. Fol. (TM 450)

Libro de los privilegios y Leyes del illustre y muy honrado Conceio de la Mesta general, y cabaña Real destos Reynos de Castilla, León, y Granada. Madrid: Pedro Madrigal, 1586. Fol. (TM 335)

Ordenanças para Remedio de los daños e inconvenientes, que se siguen de los descaminados y arribadas maliciosas de los Navios, que navegan en las Indias ocidentales. Madrid: Pedro Madrigal, 1591. Fol. (TM 496)

Para que los alcaldes de Corte, que conocen de los negocios civiles. Madrid: Pedro Madrigal, 1587. Fol. (TM 364)

Pragmática, en que se da la orden y forma que se ha de tener y guardar, en los tratamientos y cortesías de palabra y por escrito. Madrid: Pedro Madrigal, 1586. Fol.(TM 341)

Pragmática en que se declara que leguas se han de entender leguas comunes y vulgares y no de las que llaman legales. Madrid: Pedro Madrigal, 1587. Fol. (TM 365)

Premática en que se da la orden que se ha de tener en el traer de los lutos en estos Reynos. Madrid: Pedro Madrigal, 1588. Fol.(TM 392)

Premática, para que ningún Abogado lo pueda ser en las causas que se trataren en el Consejo y otros tribunalesm en que su padre, hijo, o yerno, o cuñado fuera juez. Madrid: Pedro Madrigal, 1590. Fol. (TM454) 
Premática, en que se prohíbe el arrendarse los oficios de Escrivanos de Cámara, y Procuradorias, Recetorias y Escrivanias del Número. Madrid: Pedro Madrigal, 1590. Fol. (TM456)

Premática, en que se declara y amplia, la en que se prohibió arrendar oficios de Escrivanías, Receptorias, y Procuradurias, y se mandó los sirviesen por sus personas, $y$ tuviesen de patrimonio y hazienda propia la tercia parte del valor del oficio. Madrid: Pedro Madrigal, 1590. Fol. (TM457 and 458)

Premática, de los vestidos y trajes: la qual mandó el Rey nuestro señor se publicasse el año de mil quinientos y sesenta y tres. Madrid: Pedro Madrigal, 1590. Fol. (TM459)

Premática en que se permite a los Labradores, y otras qualesquier personas que labraren, puedan vender en pan cozido todo el pan en grano que cogieren y les sobrare, proveyda su casa, registrándolo ante la justicia, y poniéndoles el precio a cómo lo hubieren de vender. Madrid: Pedro Madrigal, 1590. Fol. (TM460)

Premática, En que se prohíbe a los naturales destos Reynos no anden en ábito de romeros y peregrinos: y se da la orden que han de tener para yr á alguna romería. Madrid: Pedro Madrigal, 1590. Fol. (TM461 and 462)

Premática, para que ningún Abogado lo pueda ser en las causas que se trataren en el Consejo y otros tribunales, en que su padre, hijo, o yerno, fuere juez, y tratándose ante un juez solo no pueda abogar padre, hijo, yerno, no cuñado de tal juez. Madrid: Pedro Madrigal, 1590. Fol. (TM463)

Premática en que se revoca la en que se permitió a los labradores, y a las demás personas que cogiesen trigo de las tierras que cultivasen que lo pudiessen vender en pan cozido. Madrid: Pedro Madrigal, 1591. Fol. (TM 500)

Premática en que se da la orden en el examen de los médicos, y cirujanos, y boticarios. Madrid: Pedro Madrigal, 1593. Fol. (TM 561 and 562)

Premáticas que han salido este año de noventa y quatro, publicadas en diez y nueue días de Enero del dicho año. Madrid: Pedro Madrigal, 1594. Fol. (TM610, 611, 612, 613, and 614)

Regla primitiva y Costituciones de los Carmelitas Descalços, confirmadas por nuestro muy santo Padre Clemente VIII. Madrid: Pedro Madrigal, 1592. $8^{\circ}$. (TM 531)

Relación de algunos martirios, que ne nuevo han hecho los herejes en Inglaterra, y de otras cosas tocantes a nuestra santa y católica religión. Madrid: Pedro Madrigal, 1590. $8^{\circ}$. (TM464) 
Relación de una gravíssima persecución, que un tirano de los Reynos de Japón, llamado Canbucodono, ha levantado contra los cristianos, en los años de 88 y 89 . Madrid: Pedro Madrigal, $1591.8^{\circ}$. (TM 502)

Relación de un Sacerdote Inglés, escrita a Flandes, a un caballero de su tierra, desterrado por ser católico. Madrid: Pedro Madrigal, 1592. $8^{\circ}$. (TM 532)

Siete Partidas comentadas por Gregorio López. Madrid: Pedro Madrigal, 1587. Fol. (TM 370)

Siguense las Constituciones, que se hizieron en el capitulo general de nuestra Congregación de Descalços Carmelitas, que se celebró en Madrid en la Pascua de Pentecostés. Madrid: Pedro Madrigal, 1590. $8^{\circ}$. (TM440)

Sumario de todas las gracias e indulgencias concedidas por nro santíssimo padre Sixto. Madrid: Pedro Madrigal, 1588. $8^{\circ}$. (TM 398)

Acosta, José de. S.J. Concilium Provinciale Limense, celebratum in civitate Regum. Madrid: Pedro Madrigal, 1590. $4^{\circ}$. (TM431)

Acuña, Hernando de. Varias poesías. Madrid: Pedro Madrigal, 1591. $4^{\circ}$. (TM472)

Álaba y Viamont, Diego de. El prefeto capitán, instruído en la disciplina Militar, nueva ciencia de la Artillería. Madrid: Pedro Madrigal, 1590. Fol. (TM432)

Aldana, Francisco de. Segunda parte de las obras, que se han podido hallar del capitán Francisco de Aldana. Madrid: Pedro Madrigal, 1591. $8^{\circ}$. (TM 475)

Alonso de Orozco. Guarda de la lengua... Moralizado y anotado con muchos lugares de la sagrada Escritura. Madrid: Pedro Madrigal, 1590. 12. (TM433)

Álvares, Manoel. S.J. De constructione octo partium orationis Liber. Madrid: Pedro Madrigal, $1587.8^{\circ}$. (TM 346)

-De Constructione Octo partium orationis Liber. Madrid: Pedro Madrigal, 1593. $8^{\circ}$. (TM 540)

Anglés, José.O.F.M. Flos thelogicarum quaestionum in secundum librum sententiarum nunc primum collecti, atque in lucem editi.Madrid: Pedro Madrigal, 1586. $4^{\circ}$. (TM 325)

Antonio, Francisco. S.J. Avisos para soldados y gente de guerra. Madrid: Pedro Madrigal, $1590.12^{\circ}$. (TM434)

Arias Dávila Puertocarrerto, Juan. Discurso...para estar a la Gineta con gracia y hermosura. Madrid: Pedro Madrigal, 1590. $8^{\circ}$. (TM435) 
Auger, Emondo. S.J. Catechismus hoc est, católica christianae iuventutis institutio. Madrid: Pedro Madrigal, 1592. Fol. (TM 513)

Avendaño, Alfonso de. O.P. Commentaria in Evangelium divi Matthaei. Madrid: Pedro Madrigal, 1593. Fol. (TM 542)

Baldesano, Guillermo. Historia sacra de la ilustríssima legión Tebea. Madrid: Pedro Madrigal, 1594. $4^{\circ}$. (TM 572)

Barros, Alonso de. Philosophia cortesana moralizada. Madrid: Pedro Madrigal, 1587. $12^{\circ}$. (TM 347B)

Blosio, Ludovico. O.S.B. Instrucción espiritual y regla breve del novicio espiritual. Madrid: Pedro Madrigal, 1587. 12.(TM 348)

Capilla, Andrés. O. Cart. Obras de D. Andrés Capilla Obispo de Urgel. Madrid: Pedro Madrigal, $1592.4^{\circ}$. (TM 516)

Centelles y Borja, Magdalena. Pro Magdalena Centelles atque Borja, Gandiae Ducissa contra Iacobum, Franciscum, atque Michaelem Centelles, atque dicti Iacobi haeredes. Madrid: Pedro Madrigal, 1594. Fol. (TM 577)

Cicero. Los deziseis libros de las Epístolas, o Cartas de M. Tulio Cicerón, vulgarmente llamadaas familiares. Madrid: Pedro Madrigal, 1589. $8^{\circ}$. (TM 410)

Cornejo, Pedro. Compendio y breve Relación de la Liga y Confederación Francesa. Madrid: Pedro Madrigal, 1592. $8^{\circ}$. (TM 520)

Cortés, Diego. Discursos del varón iusto, y conversión de la Madalena, con otras Flos Espirituales. Madrid: Pedro Madrigal, 1592. $8^{\circ}$. (TM 521)

Costero, Francisco. S.J. Libellus sodalitatis, hoc est, christianarum institutionum libri tres. Madrid: Pedro Madrigal, 1592. 16². (TM 522)

Ercilla y Zúñiga, Alonso de. Tercera parte de la Araucana. Madrid: Pedro Madrigal, $1589.4^{\circ}$. (TM 412)

_. Primera, Segunda, y Tercera Partes de la Araucana. Madrid: Pedro Madrigal, $1590.8^{\circ} .(\mathrm{TM} 443)$

García, Pablo. Orden que comúnmente se guarda en el Santo Oficio de la Inquisitión cerca del procesar en las causas que en el se tratan. Madrid: Pedro Madrigal, 1591. $4^{\circ}$. (TM 484) 
González de Mendoza, Juan. O.S.A. Historia de las cosas más notables, ritos, y costumbres del gran Reino de la China. Madrid: Pedro Madrigal, 1587. $8^{\circ}$.(TM 353)

Gracián Dantisco, Tomás. Arte de escribir Cartas Familiares. Madrid: Pedro Madrigal, 1589. $12^{\circ}$. (TM 413)

Guerra de Lorca, Pedro. Catecheses Myestagogicae pro advenis ex secta Mahometana. Madrid: Pedro Madrigal, 1586. $4^{\circ}$. (TM 331)

Guevara, Pedro de. Arte general para todas las sciencias, en dos instrumentos. Madrid: Pedro Madrigal, 1586. $8^{\circ}$. (TM 332)

- Escala del entendimiento: en la qual se declaran las tres Artes... de Gramática, Dialéctica, Retórica, y la universal, para todas las sciencias. Madrid: Pedro Madrigal, 1593. $8^{\circ}$. (TM 549)

Gutiérrez, Juan. Practicarum Quaestionum, super prima parte legum novae Collectionis regiae Hispaniae. Madrid: Pedro Madrigal, 1593. Fol. (TM 550)

Herrera y Tordesillas, Antonio de. Historia de lo sucedido en Escocia, é Inglaterra en quarenta y quatro años que vivió María Estuarda Reyna de Escocia. Madrid: Pedro Madrigal, 1589. $8^{\circ}$. (TM 415)

-Cinco libros... de la Historia de Portugal, y conquista de las Islas Açores, en los años 1582 y 1583. Madrid: Pedro Madrigal, 1591. 4 . (TM 486)

Juan deÁvila. Obras del padre maestro Iuan de Avila. Madrid: Pedro Madrigal, 1588. $4^{\circ}$.(TM 386)

La Marche, Olivier de. El caballero determinado. Madrid: Pedro Madrigal, 1590. $4^{\circ}$. (TM447)

Lasso de la Vega, Gabriel. Primera parte de Cortés valeroso, y Mexicana. Madrid: Pedro Madrigal, $1588.4^{\circ}$.(TM 388)

León Hebreo. La traduzión del Indio de los tres Diálogos de Amor de León Hebreo. Madrid: Pedro Madrigal, 1590. 4 . (TM448)

Loaísa y Girón, García de. Collectio conciliorum hispaniae, diligentia Garsiae Loaisa elaborata, eiusque vigilijs aucta. Madrid: Pedro Madrigal, 1593. Fol. (TM 551)

López de Montoya, Pedro. Los quatro libros del Mysterio de la Missa, con unas anotaciones en lengua Latina sobre el sagrado Canon. Madrid: Pedro Madrigal, $1591.8^{\circ} .(\mathrm{TM} 489)$ 
Lorenzana, Rodrigo de. Compendio de los casos ordinarios de conciencia de las materias Canónicas. Madrid: Pedro Madrigal, 1591. $8^{\circ}$. (TM 490)

Mendes de Castro, Manoel. De Annonis civilibus Lib. XI. Madrid: Pedro Madrigal, 1592. $4^{\circ}$. (TM 525)

Mendoza, Bernardino de. Comentarios... de los sucedido en las Guerras de los Payses baxos, desde el Año de 1567, hasta el de 1577. Madrid: Pedro Madrigal, 1592. $4^{\circ}$. (TM 526)

Moles, Juan Bautista. O.F.M. Dotrina e instrucción de novicios de nuevo recopilada y puesta en forma. Madrid: Pedro Madrigal, 1591. $8^{\circ}$. (TM 492)

-Memorial de la provincia de San Gabriel, de la orden de los frayles Menores de Observancia. Madrid: Pedro Madrigal, 1592. 4. (TM 527)

Monterroso y Alvarado, Gabriel de. Práctica civil y criminal y instrucción de escrivanos: dividida en nueve tratados. Madrid: Pedro Madrigal, 1587. Fol.(TM 358)

- Prática civil y criminal, y instrucción de escribanos. Madrid: Pedro Madrigal, 1591. Fol. (TM 494)

Mora, Juan de. Discursos morales. Madrid: Pedro Madrigal, 1589. 4 ${ }^{\circ}$ (TM 417A and 417B)

Navarro, Antonio. O.P. Tomus primus Sermonum de Sanctis, quos sequens folium indicabit. Madrid: Pedro Madrigal, 1593. $4^{\circ}$. (TM 554)

Núñez de Avendaño, Pedro. De exequendis mandatis regum Hispaniae, quae rectoribus civitatum dantur. Madrid: Pedro Madrigal, 1593. Fol. (TM 555)

_. Quadraginta responsa quibus quam plurime leges regiae explicantur, atque illustrantur. Madrid: Pedro Madrigal, 1593. Fol. (TM 556)

Oseguera, Diego de. Estacionario de la Creación y Redención del Mundo. Madrid: Pedro Madrigal, $1593.8^{\circ}$. (TM 560)

Ovando Mongollón de Paredes, Francisco. O.F.M. Breviloquium in quartum librum magistri sententiarum. Madrid: Pedro Madrigal, $1587.4^{\circ}$.(TM 359)

Padilla, Pedro de. O.C. Grandezas y excelencias de la Virgen señora nuestra. Madrid: Pedro Madrigal, $1587.8^{\circ}$. (TM 362)

Padilla, Francisco. Oratorio real. En que se contienen muchas Oraciones, Cánticos, y Psalmos muy convenientes para rezarlos el Rey nuestro Señor por sí y por sus vasallos. Madrid: Pedro Madrigal, 1592. 12 . (TM 528) 
Pérez de Moya, Juan. Manual de contadores. Madrid: Pedro Madrigal, 1589. $8^{\circ}$. (TM 420)

Ramírez, Jerónimo. De Raptu Inocentis Martyris Guardensis, libri sex. Madrid: Pedro Madrigal, $1592.4^{\circ}$. (TM 530)

Ribadeneyra, Pedro. S.J. Historia ecclesiastica del scisma del reyno de Ingleterra. Madrid: Pedro Madrigal, 1588. $8^{\circ}$. (BM 289 and 290; IB 15848 and 15849; TM 394 and 395)

Tratado de la Tribulación. Madrid: Pedro Madrigal, 1589. $8^{\circ}$. (BM 315; IB 15855; TM 423)

—. Vida de P. Francisco de Borja. Madrid: Pedro Madrigal, 1592. 4. (TM 534)

Vida del P. Ignacio de Loyola. Madrid: Pedro Madrigal, 1593. (TM 564)

-Vida del P. Ignacio de Loyola, fundador de la religión de la Compañía de Jesús: y de los Padres Maestros Diego Laynez, y Francisco de Borja. Madrid: Pedro Madrigal, 1594. Fol. (TM 618)

Ríos, Gregorio de los. Agricultura de Iardines, que trata la manera que se han de criar, gobernar, y conservar las plantas. Madrid: Pedro Madrigal, 1592. $8^{\circ}$. (TM 533)

Roa Dávila, Juan. Apologia de Iuribus principalibus, defendis, atque moderandis iuste. Madrid: Pedro Madrigal, 1591. Fol. (TM 504)

De suprema Dei providentia, atque praedestinatione, Libri tres. Madrid: Pedro Madrigal, 1591. Fol. (TM 505)

Sabuco, Miguel. Nueva filosofia de la naturaleza del hombre, no conocida ni alcançada de los grandes filósofos antiguos. Madrid: Pedro Madrigal, 1587. $8^{\circ}$. (TM 369)

- Nueva filosofia de la naturaleza del hombre, no conocida ni alcançada de los grandes filósofos antiguos. Madrid: Pedro Madrigal, 1588. $8^{\circ}$. (TM 396)

Simón Abril, Pedro. La gramática griega escrita en lengua Castellana, para que desde luego puedan los niños aprender la lengua Griega.Madrid: Pedro Madrigal, 1587. $8^{\circ}$. (TM 371)

Apuntamientos, de cómo se deven reformar las dotrinas: y la manera del enseñallas, para reduzillas a su antigua entereza y perfición. Madrid: Pedro Madrigal, 1589. $4^{\circ}$. (TM 425) 
Solórzano, Bartolomé Salvador de. Libro de caxa y manual de cuentas de mercaderes, y otras personas. Madrid: Pedro Madrigal, 1590. $4^{\circ}$. (TM468)

Tasso, Torquato. Jerusalem libertada. Madrid: Pedro Madrigal, 1587. $8^{\circ}$. (TM 373)

Valdés, Francisco de. Diálogo militar... En el qual se trata el oficio de Sargento mayor. Madrid: Pedro Madrigal, 1590. $8^{\circ}$. (TM469)

Vargas Manrique, Luis de. Christados o libro de los hechos de Christo. Madrid: Pedro Madrigal, $1589.8^{\circ}$. (TM 428)

Vasconcelos, Pedro Alfonso de. De harmonia rubricarum iuris canonici prima, et secunda pars. Madrid: Pedro Madrigal, 1590. 4 ${ }^{\circ}$ (TM470)

Villegas y Selvago, Alonso de. Flos sanctorum y historia general, de la vida y hechos de Jesu Christo, Dios y señor nuestro, y de todos los santos de que reza y haze fiesta la iglesia catholica confrome al brevario romano, reformado por decreto del sancto concilio Tridentino, junto con las vidas de los sanctos proprios de Espana, $y$ de otros extravagantes. Madrid: Pedro Madrigal, 1588. Fol. (IB 19569; TB 402)

-Flos sanctorum quarta y ultimate parte. Madrid: Pedro Madrigal, 1589. Fol. (BM 318; IB 19577; TM 430)

-Flos sanctorum. Madrid: Pedro Madrigal, 1592. Fol. (IB 19590)

- Flos Sanctorum quarta y última parte, y discursos, o sermones, sobre los Evangelios de todas las Dominicas del año. Madrid: Pedro Madrigal, 1593. Fol. (TM 566 and 567)

_. Flos Sanctorum, y Historia General, de la vida de y hechos de Iesu Christo...y todos los Santos. Madrid: Pedro Madrigal, 1594. Fol. (TM 624)

\subsection{Widow of Madrigal (Maria Rodriguez Rivalde) Period: 1595-1604}

Bulas Apostólicas concedidas a los Hermanos de la Orden y Hospitalidad de San Juan de Dios, las quales valen en España, en las Indias y en todas partes donde esta vinieren los hermanos de dicha Hospitalidad. Madrid: Pedro Madrigal, 1596. Fol. (TM686)

Contemptus mundi, o Menosprecio del mundo. Madrid: Pedro Madrigal, 1596. $16^{\circ}$. (TM694)

Contemptus mundi, ó menosprecio del mundo.Madrid: Pedro Madrigal, 1599. $16^{\circ}$.(TM 847) 
Libro de las leyes, privilegios, y provisiones reales del Honrado Concejo de la Mesta, y cabaña Real destos Reynos. Madrid: Pedro Madrigal, 1595. Fol. (TM650)

Libro de los annales de los niños que han sido baptizados en la Iglesia de San Ginés. Madrid: Pedro Madrigal, 1599. Fol.(TM 851 bis)

Las siete Partidas comentadas por Gregorio López. Madrid: Pedro Madrigal, 1595. (TM677)

Ordenaciones provincials para el buen gobierno de las provincias de los Descal[c]os de S. Joseph y S. Pablo. Madrid: Pedro Madrigal, 1597. Fol. (TM744)

Premática en que se prohibe a qualesquier personas, así naturales destos Reynos, como estrangeros, que traxeren o metieren en ellos qualesquier libros impressos, no los puedan vender sin que primero sean tassados. Madrid: Pedro Madrigal, 1598. Fol.(TM 810)

Premática en que se manda Guardar las Leyes en que se prohibe matar terneras y terneros, y se acrecientan las penas contra los que las hizieren matar, o mataren. Madrid: Pedro Madrigal, 1598. Fol.(TM 811)

Premática que han salido este año de mil quinientos y noventa y ocho, publicadas en veynitiquatro dias del mes de Iulio del dicho año. Madrid: Pedro Madrigal, 1598. Fol.(TM 812 and 813)

Premática y nueva Orden para el conocimiento y determinación de las causas civiles y criminales dada a los Alcaldes desta Corte. Madrid: Pedro Madrigal, 1600. Fol.(TM 954 and 955)

Premáticas que han salido este año de mil y seiscientos, publicadas en tres dias del mes de junio del dicho año. Madrid: Pedro Madrigal, 1600. Fol.(TM 956 and 957)

Premáticas que han salido este año de mil y seyscientos, publicadas en veynte y siete días del mes de otubre del dicho año. Madrid: Pedro Madrigal, 1600. Fol.(TM 958 and 959)

Acevedo, Alfonso de. Commentarionum iuris civilis in Hispaniae Regias Constitutiones... Tomus secundus. Madrid: Pedro Madrigal, 1595. Fol. (TM626)

. Commentariorum Iuris Civilis in Hispaniae Regias Constitutiones, tres primos libros novae Recopilationis complectens. Tomus Primus. Madrid: Pedro Madrigal, 1599. Fol.(TM 826)

. Commentariorum continuatio ad Leges Regias nunc denuo post Recopilationem Regiam in curijs \& extra constituas. Madrid: Pedro Madrigal, 1600. Fol.(TM 901) 
Amoraga, Pedro. O.Min. Libro intitvlado Instrucción del Pecador, en dialogo. Madrid: Pedro Madrigal, 1602. $4^{\circ}$. (BM 805)

Ángeles,Juan de los. O.P. Lucha Espiritual y Amorosa entre Dios y el Alma, en que se descubren las grandezas y triunfos del amor, y se enseña el camino excelentíssimo de los afectos. Madrid: Pedro Madrigal, 1600. $8^{\circ}$.(TM 930)

Antonio, Francisco. S.J. Consideraciones sobre los misterios del altíssimo sacrificio de la Missa. Madrid: Pedro Madrigal, 1596. $4^{\circ}$. (TM681)

-Consideraciones sobre los Mysterios del Altissimo sacrificio de la Missa. Madrid: Pedro Madrigal, 1598. $4^{\circ}$. (TM 764)

Ávila y Padilla, Agustín de. O.P. Historia de la fundación y discurso de la Provinçia de Santiago de México de la Orden de Predicadores, por las vidas de sus varones insignes, y casos notables de la Nueva España. Madrid: Pedro Madrigal, 1596. Fol. (TM683)

Aviles, Francisco de. Nova Diligens, ac Perutilis Expositio Capitum, seu legem Praetorum, ac Iudicum syndicatus regni totius Hispaniae. Madrid: Pedro Madrigal, 1597. Fol. (TM 717)

Baldesano, Guillermo. Historia sacra de la ilustríssima Legión Tebea. Madrid: Pedro Madrigal, 1596. $4^{\circ}$. (TM684)

Cortés, Jerónimo. Libro de phisonomia natural y varios secretos de la naturaleza. Madrid: Pedro Madrigal, 1598. $8^{\circ}$. (TM 780)

- Lunario Nuevo, perpetuo y general y Pronostico de los tiempos, universal. Madrid: Pedro Madrigal, 1598. $8^{\circ}$.(TM 781)

Cresuelo, José. S.J. Historia de la Vida y Martyrio que padeció en Inglaterra, este año de 1595, el P. Henrique Valpolo. Madrid: Pedro Madrigal, 1596. $8^{\circ}$. (TM687)

Falcó, Jacobo. Operum Poeticorum...Libri quinque. Madrid: Pedro Madrigal, 1600. $8^{\circ}$.(TM 922)

González, Cristóbal. O.Mer. Segunda parte de los Discvrsos Espirituales, y predicables, sobre dozes lugares del Genesis. Madrid: Pedro Madrigal, 1603. 4º (BM 834)

Gracian de la Madre de Dios, Jerónimo. O.C.D. Dilucidario del verdadero espiritv, en que se declara, que sea espiritu verdadero: de donde mana: y sus grados. Madrid: Pedro Madrigal, 1604. 4 . (BM 866) 
Gutiérrez, Juan. D. Ioannis Gvtierrez almae Ecclesiae Civitatensis Canonici Doctoralis, Repetitiones sex \& quatuordecim iuris Allegationes. Madrid: Pedro Madrigal, 1604. Fol. (BM 870)

Gutiérrez de los Ríos, Gaspar. Noticias general para la estimación de las Artes y manera en que se conocen las liberales de las que son Mecánicas. Madrid: Pedro Madrigal, $1600.4^{\circ}$.(TM 926)

Herrera y Tordesillas, Antonio de. Segunda parte de la historia general del mundo. Madrid: Pedro Madrigal, 1600. Fol.(TM 927)

Juan de Ávila. Tercera parte de las obras. Madrid: Pedro Madrigal, 1596. 4. (TM696)

Lasarte y Molina, Ignacio de. Additamenta in suo tractatu de decima venditionis \& permutationis, quae Alcavala nuncupantur. Madrid: Pedro Madrigal, 1599. Fol.(TM 850 and 851)

El Licenciado Salinas. Sumario de la memorable, y santa batalla de Clauijo, cierto y cerdadero origen, $y$ antigüedad del Señorio, y señores de la villa, solar y diuisas de Val de Osera. Madrid: Pedro Madrigal, 1601. $4^{\circ}$. (BM 794)

Llamas, Jerónimo. O. Cist. Methodus Curationis Animorum Quatuor Patribus. Madrid: Pedro Madrigal, $1600.4^{\circ}$.(TM 933)

López de Tovar, Gregorio. Repertorio muy copioso del texto y Leyes de las siete Partidas. Madrid: Pedro Madrigal, 1598. Fol.(TM788)

Maldonado de Matute, Hernando. Memoria y discurso que la Villa de Madrid dio al Rey don Felipe III... sobre la mudança de la Corte. Madrid: Pedro Madrigal, 1600. Fol.(TM 935)

Malón de Chaide, Pedro. O.S.A. Libro de la conversión de la Magdalena, en que se ponen los tres estados que tuvo de Pecadora, y de Penitente, y de Gracia. Madrid: Pedro Madrigal, 1598. $8^{\circ}$.(TM 790)

Manfredi, Girolamo. Libro llamado El Porque, provechosíssimo para la conservación de la salud y para conocer las fisonomías y las virtudes de las yervas. Madrid: Pedro Madrigal, 1598. $8^{\circ}$.(TM 791)

Marieta, Juan de. O.P. Catalogo de los Obispos de Avila, desde san Segundo hasta aora. Madrid: Pedro Madrigal, 1602. $4^{\circ}$. (BM 812 and 814)

Matienzo, Juan de. Commentaria... in librum quantum recollectionis legum Hispaniae. Madrid: Pedro Madrigal, 1597. Fol. (TM 736) 
Mercado, Luis. De natura \& conditionibus, praeservatione, \& curatione pestis, quae populariter grassantur his temporibus. Madrid: Pedro Madrigal, 1598. 16.(TM 801)

-Instituciones... para el aprovechamiento y examen de los Algebristas. Madrid: Pedro Madrigal, 1599. $4^{\circ}$.(TM 858)

Moles, Juan Bautista. O.F.M. Tratado del espiritu prophético y prophecías con que Dios honró a nuestro seráphico padre S. Francisco y epílogo de sus milagros, en beneficio de su Iglesia. Madrid: Pedro Madrigal, 1600. $8^{\circ}$.(TM 939)

Monterroso y Alvarado, Gabriel de. Pratica civil y criminal, y Instrvcion de Escrivanos. Madrid: Pedro Madrigal, 1603. Fol. (BM 842)

Natin Miriteo, Rolando. Comentarios de las Alteraciones de los Estados de Flandes, sucedidas después de la llegada del señor don Iuan de Austria a ellos, hasta su muerte. Madrid: Pedro Madrigal, 1601.4. (BM 789)

Navarro, Antonio. O.P. Abecedario Virginal de Excelencias del Santissimo nombre de Maria. Madrid: Pedro Madrigal, 1604. $4^{\circ}$. (BM 882)

Navarro, Miguel. Aliqua ex classicis autoribus pro Prima, Secunda, \& Tertia classe Grammaticae collecta. Madrid: Pedro Madrigal, 1597. $8^{\circ}$. (TM 740)

Páramo, Luis de. Responsum...adversus obiectiones secundo loco, excitatas contra iurisdictionem sancti Officij Regni Siciliae. Madrid: Pedro Madrigal, 1599. $4^{\circ} .(\mathrm{TM} 869)$

Peliger, Juan Vicente. Formulario y estilo curioso de escrivir cartas missivas, según la orden que al presente se guarda. Madrid: Pedro Madrigal, 1599. $8^{\circ}$.(TM 871)

Pliny the Elder. Libro Nono de Caio Plinio Segvndo, de la Historia Natural de los pescados del mar, de lagos, estanques, y ríos. Madrid: Pedro Madrigal, 1603. $4^{\circ}$. (BM 848)

Raulín, Juan. O.S.B. Libro de la muerte temporal y eterna. Madrid: Pedro Madrigal, 1596. $8^{\circ}$. (TM709)

Ribadeneyra, Pedro de. S.J. Tratado de la Religión y Virtudes que debe tener el Príncipe Christiano, para gobernar y conservar sus Estados. Madrid: Pedro Madrigal, 1595. $4^{\circ}$. (TM673)

-Vita Ignatii Loiolae, qui Religionem clericum Societatis Iesu instituit. Madrid: Pedro Madrigal, 1595. $8^{\circ}$. (TM674) 
Ruiz Bejarano, Pedro. Responsum redditum pro Petro Vich in causa Baroniae, \& reliquorum bonorum contra D. Raymundum de Rocafull. Madrid: Pedro Madrigal, 1598. Fol.(TM 817)

Sa, Emmanuel. S.J. Aphorismi Confessariorum ex Doctorum sententijs collecti. Madrid: Pedro Madrigal, 1601. 16². (BM 793)

Saavedra Guzmán, Antonio de. El Peregrino Indiano. Madrid: Pedro Madrigal, 1599. $8^{\circ} .($ TM 880$)$

Santiago, Hernando de. O.Mer. Consideraciones sobre todos los Evangelios de los Domingos y Ferias de la Quaresma. Madrid: Pedro Madrigal, 1599. $4^{\circ}$.(TM 845)

- Consideraciones sobre todos los Evangelios de los Santos que con mayor solenidad celebra la Iglesia. Madrid: Pedro Madrigal, 1603. $4^{\circ}$.(BM 850)

Suarez, Cipriano. S.J. De arte rhetorica libri tres, ex Aristot. Cicer. \& Quintiliano praecipue deprompti. Madrid: Pedro Madrigal, 1597. $8^{\circ}$. (TM 752)

Suárez, Francisco. S.J. Commentariorum ac Disputationum in Tertiam Partem Divi Thomae.Tomus secundus. Madrid: Pedro Madrigal, 1598. Fol.(TM 821)

Turselino, Horacio. S.J. Historia Lavretana, en que se cventan las traslaciones, milagros, y sucesos de la santa casa de N. Señora de Loreto. Madrid: Pedro Madrigal, 1603. $4^{\circ}$.(BM 852)

Valle de la Cerda, Luis. Avisos en Materia de Estado y Guerra, para oprimir Rebeliones, $y$ hazer pazes con enemigos armados, o tratar con súbditos rebeldes. Madrid: Pedro Madrigal, $1599.4^{\circ}$.(TM 893)

—.Desempeño del Patrimonio de su Magestad.Madrid: Pedro Madrigal, 1600. $4^{\circ}$.(TM969)

Vargas Machuca, Bernando de. Milicia y Descripción de las Indias. Madrid: Pedro Madrigal, 1599. $4^{\circ}$.(TM 894)

Libro de Exercicios de la Gineta. Madrid: Pedro Madrigal, 1600. $8^{\circ}$.(TM 970)

Vega Carpio, Lope Félix de. La Hermosvra de Angelica, Con otras diuersas Rimas. Madrid: Pedro Madrigal, 1602. $8^{\circ}$. (BM 826)

Isidro. Madrid: Pedro Madrigal, 1602. $8^{\circ}$. (BM 827)

Arcadia Prosas, y Versos de Lope de Vega Carpio, Secretario del Marques de Sarria. Madrid: Pedro Madrigal, 1603. $8^{\circ}$.(BM 855) 
IIsidro. Madrid: Pedro Madrigal, 1603. $8^{\circ}$. (BM 856)

Velez de Arciniega, Francisco. Libro de los Quadrupedes y Serpientes terrestres, recebidos en el uso de la medicina, y de la manera de su preparacion. Madrid: Pedro Madrigal, 1597. $8^{\circ}$. (TM 754)

Vélez de Jaén, Fernando. Discurso sobre la utilidad y aprovechamiento que a V.M. Reyno y vasallos resulta en labrarse moneda de vellón en las ocho casas de moneda destos Reynos. Madrid: Pedro Madrigal, 1599. Fol.(TM 897)

Villadiego Vascuña y Montoya, Alfonso de. Forus Antiquus Gothorum Regum Hispaniae olim Liber Iudicum.Madrid: Pedro Madrigal, 1600. Fol.(TM 972)

Yanguas, Didacus de. O.P. De cardinalibvs et praecipvis, Iesvchristi, et Sanctorum operitbvs, quae festis eorum diebus in Ecclesia festiué celebrantur. Tomus primvs.Madrid: Pedro Madrigal, 1602. 2 vols. $4^{\circ}$. (BM 828) 


\section{APPENDIX 4: BOOKS BY THE SÁNCHEZ HOUSE OF MADRID}

\subsection{Pre-Valladolid Era (1590-1601)}

\begin{tabular}{|c|c|c|c|c|c|}
\hline \multicolumn{6}{|c|}{ Printing Tendencies in the Sánchez Print House (1590-1601) } \\
\hline \multicolumn{2}{|c|}{ Annual Production } & \multicolumn{2}{|c|}{ Format Production } & \multicolumn{2}{|c|}{ Linguistic Production } \\
\hline Year & Amount & Size & Amount Produced & Language & Amount \\
\hline 1590 & 0 & Folio & 25 & Castilian & 69 \\
\hline 1591 & 5 & Quarto & 31 & Latin & 29 \\
\hline 1592 & 4 & Octavo & 26 & & \\
\hline 1593 & 6 & Duodecimo & 3 & & \\
\hline 1594 & 7 & Sextodecimo & 6 & & \\
\hline 1595 & 8 & T.Secundo & 1 & & \\
\hline 1596 & 5 & \multirow{2}{*}{\multicolumn{2}{|c|}{ Production by Order }} & \multicolumn{2}{|c|}{ Stylistic Production } \\
\hline 1597 & 7 & & & Type of Work & Amount \\
\hline 1598 & 13 & Order & Number of Writers & Ecclesiastic & 25 \\
\hline 1599 & 16 & Jesuits & 10 & Devotional & 26 \\
\hline 1600 & 20 & Franciscans & 4 & Philosophical & 3 \\
\hline 1601 & 7 & Dominicans & 3 & Utilitarian & 25 \\
\hline s.a. & 0 & Merceds & 1 & Classics & 1 \\
\hline Total & 98 & Benedictines & 1 & Entertainment & 11 \\
\hline & & Trinitarians & 1 & Secular Histories & 7 \\
\hline & & Hieronymite & 1 & & \\
\hline
\end{tabular}

Catecismo de la doctrina cristiana. Madrid: Luis Sánchez, 1600. (BM 680)

Coronica del Esforçado Principe y Capitan Iorge Castrioto. Rey de Epiro, óAlbania. Madrid: Luis Sánchez, 1597. Fol. (BM 535)

Lazarillo de Tormes. Madrid: Luis Sánchez, 1600. (BM 691)

Memoria de la Passion de N.S. Iesu Christo, Por vn pobrezito Pecador. Madrid: Luis Sánchez, 1599. $4^{\circ}$. (BM 631)

Reglas de la Compañía de Iesvs, y la Carta de la obdeiencia de nuestro B.P. Ignacio. Madrid: Luis Sánchez, 1600. 16². (BM 714)

Responsum ad causam feudorum civitatis Plovacensis, \& oppidorum de Salvennor, \& Florinas. Madrid: Luis Sánchez, 1596. Fol. (BM 523)

Romancero General, en que se contienen todos los Romances que andan impressos en las nueue partes de Romanceros. Madrid: Luis Sánchez, 1600. 4. (BM 715) 
Agia,Miguel de. O.F.M. F. Michaelis Agia, Valentini, Ordinis Sancti Francisci publici sacre Theologiae professoris De Exhibendis Avsiliis, sive de inuocatione vtriusque. Madrid: Luis Sánchez, 1600. $8^{\circ}$. (BM 670)

Alaba, Pedro de. O.F.M. Doctrinal satisfactorio de los Frayles menores de la regular Obseruancia del Serafico Padre S. Francisco. Madrid: Luis Sánchez, 1601. 4. (BM 770)

Alagón, Artal de. Concordia de leyes divinas. Madrid: Luis Sánchez, 1593. 4º (BM 399)

Alagón, Pedro.S.J. Compendium Manvalis Navarri, Ad commodiorem usum, tum confessariorum, tum poenitentium, compilatum. Madrid: Luis Sánchez, 1594. $16^{\circ}$. (BM 427)

Aldana, Cosme de. Invectiva contra el vvlgo y sv maledicencia, con otras octavas, y Versos de Cosme de Aldana, Gentilhombre entretenido por su Magestad Catolica. Madrid: Luis Sánchez, 1591. 8. (BM 350)

Aldana,Francisco de. Todas las obras que hasta Agora se han podido hallar del Capitan Francisco de Aldana Alcayde de San Sebastian, que fue Maestro de Campo General del Rey de Portugal en la jornada de Africa, á do murio peleando. Madrid: Luis Sánchez, 1593. $8^{\circ}$. (BM 400)

Barbosa, Pedro. Commentariorvm ad interreptationem tituli. 2 vols. Madrid: Luis Sánchez, 1595. Fol. (BM 465)

Bartholomew of the Martyrs. O.P. Compendium Spiritualis Doctrinae, ex variijs Sanctorum Patrum sentenciis magna ex parte collectum. Madrid: Luis Sánchez, 1598. $16^{\circ}$. (BM 579)

Bocángel, Nicolás. Libro de las Enfermedades malingas y pestilentes, causas, pronosticos, curacion, y preseruacion. Madrid: Luis Sánchez, 1600. 4. (BM 676)

- De Moribis malignis et pestilentibvs, causis, presagijs, \& medendi método: de remedijs insuper preseruatiuis, Tratatus. Madrid: Luis Sánchez, 1600. 4. (BM 677)

Botero,Juan. Diez libros de la Razon de Estado. Madrid: Luis Sánchez, 1593. 8². (BM 404)

Calderari,Cesare. Conceptos scripturales sobre el Magnificat, del muy R. Cesar Calderari de Vicenza, Canonigo Lateranese. Madrid: Luis Sánchez, 1600. $8^{\circ}$. (BM 678)

Castillo de Bovadilla, Jerónimo. Politica para Corregidores y Señores de vassallos, en tiempo de paz, y de guerra. Madrid: Luis Sánchez, 1597. 2 vols. Fol. (BM 532) 
Cervera de la Torre, Antonio. Testimonio Avtentico y verdadero de las cosas notables que pasaron en la dichosa muerte del Rey N.S. don Felipe II. que santa gloria aya. Madrid: Luis Sánchez, 1600. 4. (BM 681)

Ceverio de Vera, Juan. Viaie de la Tierra Santa, y descripcion de Ierusalen, y del santo monte Libano, con relacion de cosas marauillosas, assi de las prouincias de Leuante, como de las Indias de Occidente. Madrid: Luis Sánchez, 1597. 8º (BM 533)

Cianca, Antonio de. Historia de la vida, invencion, milagros, y translacion de $S$. Segundo, primero Obispo de Avila. Madrid: Luis Sánchez, 1595. 4. (BM 469)

Colonna, Ascanio. Ascanii. S.R.E. Diac. Cardinalis Columnae, Oratio in sunere Philippi. II. Catholici Hispaniarum, \& Indiarum Regis potentissimi. Madrid: Luis Sánchez, 1599. $4^{\circ}$. (BM 618)

Costero, Francisco. S.J. De vniversa historia Dominicae Passionis. Madrid: Luis Sánchez, $1600.16^{\circ} .(\mathrm{BM} 682)$

- De vita et lavdibvs Dei parae Mariae Virginis Meditationes quinquaginta. Madrid: Luis Sánchez, 1600. 16². (BM 683)

Covarrubias, Antonio de. Informacion en derecho de Don Gomez Dauila, Marques de Velada, sobre el estado de Villatoro, con don Henrique Dauila, y don Diego Dauila, que a este pleyto se opuso. Madrid: Luis Sánchez, 1595. Fol. (BM 470)

Cruz, Luis de la. S.J. Interpretatio Poetica latine incentum quinqvaginta Psalmos. Madrid: Luis Sánchez, 1600. $8^{\circ}$. (BM 684)

Díaz, Duarte. Varias obras De Dvarte Diaz, em ligoa Portugesa, e Castelhana. Madrid: Luis Sánchez, 1592. 4 . (BM 384)

Díaz, Nicolás. O.P. Tratado del Ivyzio final, en el qual se hallaran muchas cosas muy curiosas, y prouechosas para la salud de las almas, y recreacion de los que las leyeren. Madrid: Luis Sánchez, 1599. 4. (BM 622)

Dosma Delgado, Rodrigo. S.J. Expositio sive Paraphrasis in sacros centrum quinquaginta Psalmos, \& in Cantica Canticorum, cum annotationibus, \& scholijs. Madrid: Luis Sánchez, 1601.4. (BM 777)

Eguiluz, Martín de. Milicia, discvrso, y regla militar, del Alferez Martin de Eguilvz, vizcayno. Madrid: Luis Sánchez, 1592. $8^{\circ}$. (BM 385) 
Espinel, Vicente. S.J. Diversas Rimas de Vicente Espinel Beneficiado de las Iglesias de Ronda, con el Arte Poetica, y algunas Odas de Oracio, traduzidas en verso Castellano. Madrid: Luis Sánchez, 1591. 8. (BM 353 and 354)

Fernández, Tello. Prima Pars Commentariorum in primas triginta et Octo leges Tauri. Madrid: Luis Sánchez, 1595. Fol. (BM 472)

Fuenmayor, Antonio de. Vida y Hechos de Pio V. Pontifice Romano, diuidida en seis libros. Madrid: Luis Sánchez, 1595. 4². (BM 473)

Gálvez de Montalvo, Luis. El Pastor de Filida. Madrid: Luis Sánchez, 1600. 8º (BM 688)

Garibay, Esteban de. Letreros e Insignias Reales de todos los serenissimos Reyes de Obiedo, Leon, y Castilla, para la Sala Real de los alcazares de Segouia, ordena dos por mandado del Catholico Rey nuestro Señor Don Philipe el II. Madrid: Luis Sánchez, 1593. Fol. (BM 407)

- Illvstraciones Genealogicas de los Catholicos Reyes de las Españas, y de los Christianissimos de Francia, y de los Emperadores de Constantinopla, hasta el Catholico Rey nuestro señor Don Philipe el II. Madrid: Luis Sánchez, 1596. Fol. (BM 510)

González de Torneo, Francisco. Pratica de Escrivanos, que contiene la judicial. Madrid: Luis Sánchez, 1600. $8^{\circ}$. (BM 689)

Gracián Dantisco, Lucas. Galateo espanol agora nueuamente impresso y emendado. Madrid: Luis Sánchez, 1599. (BM 625)

Granado, Diego. Libro del Arte de cozina. Madrid: Luis Sánchez, 1599. $8^{\circ}$. (BM 627)

Gutiérrez, Juan. Canonicarum utriusque fori, tam exterioris, quam interioris animae, quaestionum. Madrid: Luis Sánchez, 1597. Fol. (BM 537)

- Tractatvs de Ivramento confirmatorio, et aliis in ivre variis resolvtionibvs. Madrid: Luis Sánchez, 1597. Fol. (BM 538)

- Practicarum Qvaestionum circa leges regias Hispaniae Primae partis Novae Collectionis Regiae Libri duo. Madrid: Luis Sánchez, 1598. Fol. (BM 571)

Guzmán, Diego. O.SS.T. Tratado de la Excelencia del Sacrificio de la Ley Evangelica. Madrid: Luis Sánchez, 1594. 4. (BM 436)

Herrera y Tordesillas, Antonio de. Primera parte de la Historia general del Mundo, de XVI años del tiempo del señor Rey don Felipe II. Madrid: Luis Sánchez, 1601. Fol. (BM 785) 
Herrera, Gabriel Alonso de. Libro de Agricvltvra, que trata de la labrança y criança, y de muchas otras particularidades y prouechos del campo. Madrid: Luis Sánchez, $1598.4^{\circ}$. (BM 573)

Juan deÁvila.Primera parte de las Obras del Padre Maestro Ivan de Avila, Predicador en el Andalvzia. Madrid: Luis Sánchez, 1595. 4. (BM 463)

Lasso de la Vega, Gabriel.Mexicana de Gabriel Lasso de la Vega, emendada y añadida por su mismo Autor. Madrid: Luis Sánchez, 1594. $8^{\circ}$. (BM 438)

Londoño, Sancho de. Discurso sobre la formá de revzir la disciplina militar á mejor y antiguo estado, Compuesto por Don Sancho de Londoño Maestro de Campo. Madrid: Luis Sánchez, 1593. 4. (BM 411)

López de Montoya, Pedro. De Concordia Sacrarum editionum libri dvo. Madrid: Luis Sánchez, 1596. $4^{\circ}$. (BM 513)

- Libri dvo de Concordia Sacrarum Scripturarum, cum introductoriis quaestionibus ad earum studia \& noua explicatione plurium locorum difficilium. Madrid: Luis Sánchez, 1600. 4. (BM 694)

Magallanus, Cosmas. S.J. Sylvae Illustrium Avtorvm, qvi ad vsvm Collegiorvm Societatis Iesv, selecti svnt per Patrem Cosmam Magallanum eiusdem Societatis Volvmen primvm In duos diuisum tomos. Madrid: Luis Sánchez, 1598. $8^{\circ}$. (BM 576)

Mercado, Luis. Institvtiones Chirvrgicae ivssv regio factae pro chirvrgis in praxi examinandis: authore Ludouico Mercato, Philippi. II. Hispaniarum, Indiarumque. Madrid: Luis Sánchez, 1594. $8^{\circ}$. (BM 440 and 441)

Montemayor, Jorge de. Los siete libros de la Diana de Jorge de Montemayor. Madrid: Luis Sánchez, 1591. 12. (BM 362)

- Primera y segunda Parte de la Diana de George de Montemayor. Madrid: Luis Sánchez, 1595. 12º. (BM 489)

—. Los siete libros de la Diana. Madrid: Luis Sánchez, 1599. 8. (BM 636)

Mosquera de Figueroa, Cristóbal. Comentario en Breve compendio de disciplina Militar, en que se escriue la jornada de las islas de los Açores. Madrid: Luis Sánchez, 1596. $4^{\circ}$. (BM 516)

Oña, Pedro de. O.Mer.Sermon que predico a la Magestad Catolica del Rey nuestro señor Filipo III. Madrid: Luis Sánchez, 1599. 4 . (BM 639) 
Oviedo, Luis de. Methodo de la coleccion y reposicion de las medicinas simples, u de su correcion y preparacion. Madrid: Luis Sánchez, 1595. 4. (BM 491)

Páramo, Luis de. Responsum D. Ludouici de Paramo, Inquisitoris Reni Siciliae, pro defensione jurisdictionis Sancti Officii, adversus oppositions \& capitua judicum secularium eiusdem Regni. Madrid: Luis Sánchez, 1594. 4º (BM 444)

Patrizi, Francesco. Francisco Patricio de Reyno, y la Institucion del que Ha de Reynar, y de como deueauerse con los subditos, y ellos con el. Madrid: Luis Sánchez, 1591. $4^{\circ}$. (BM 365)

Pérez, Antonio. Breve Tratado de Peste, con sus causas, señales y curacion. Madrid: Luis Sánchez, 1598. $8^{\circ}$. (BM 591)

Pérez de Herrera,Cristóbal. Discursos de lamparo de los legitimos pobres, y redvccion De los fingidos. Madrid: Luis Sánchez, 1598. 4. (BM 592)

Pérez de Moya, Juan. Arismetica, Practica, y Especvlativa del Bachiller Iuan Perez de Moya. Madrid: Luis Sánchez, 1598. $8^{\circ}$. (BM 594)

Pliny the Elder. Tradvcion de los libros de Caio Plinio Segundo, de la Historia Natvral de los Animales. Madrid: Luis Sánchez, 1599. 4. (BM 645)

Pseudo-Augustine. Libros de las meditaciones y soliloquios y manualdel glorioso doctor de la iglesia san Agustin. Trans. Pedro de Ribadeneyra. Madrid: Luis Sánchez, 1597. (BM 556; IB 1367)

Quintanadueñas, Antonio. De Ivrisdictione et Imperio. Madrid: Luis Sánchez, 1598. 4. (BM 601)

Ribadeneyra, Pedro de. S.J. Flos sanctorum o libro de las vidas de los santos. Madrid: Luis Sánchez, 1599. Fol. (BM 646; IB 15877)

- Segunda parte del Flos sanctorum, o libros de las Vidas de los Santos. En la qual se contienen las vidas de todos los Santos que reza la Iglesia Romana en los seys postreros meses del Año. Madrid: Luis Sánchez, 1601. Fol. (BM 791; JS 1548)

- Tratado de la Religion y virtudes que deve tener el Principe Christiano, para gouernar y conseruar sus estados. Contra lo que Nicolas Machiauelo y los Politicos deste tiempo enseñan. Madrid: Luis Sánchez, 1601. (BM 792; JS 1528)

Ribera, Diego de. Primera Parte de Escrituras, y Orden de particion y cventa, y de residencia judicial, ciuil, y criminal, con vna instrucion a los escriuanos del Reyno al principio, y su aranzel. Madrid: Luis Sánchez, 1596. Fol. (BM 526) 
Ribera, Juan de. Declaracion del Credo y Simbolo de los Apostoles, y de la Oracion del Paternoster, $y$ de los dos precetos de Caridad amor de Dio, y del proximo, y de los diez mandamientos de la ley de Dio. Madrid: Luis Sánchez, 1591. 4. (BM 369)

Rojas, Cristóbal de. Teorica y practica de fortificacion, conforme las medidas y defensas destos tiempos, repartida en tres partes. Madrid: Luis Sánchez, 1598. Fol. (BM 603)

Sa, Emmanuel. S.J. Aphorismi Confessariorum ex Doctorum sentenijs collecti. Madrid: Luis Sánchez, $1600.16^{\circ}$. (BM 716)

Salmerón, Alfonso. S.J. Commentariorum in Sacrosancta Iesu Christi Evangelia Tomus septimus, Qui inscribitur de Parabolis Domini. Madrid: Luis Sánchez, 1597. Fol. (BM 550)

- Alfonsi Salmeronis Toletani, e Societate Iesv Theologi, Commentarii in Evangelicam Historiam \& in Acta Apostolorum. Vol. 1 Madrid: Luis Sánchez, 1598. Fol. (BM 605)

-2. Alfonsi Salmeronis Toletani, e Societate Iesv Theologi, Comentarii in Evangelicum Historiam, \& in Acta Apostolorum. Vols. 2-6. Madrid: Luis Sánchez, 1599. Fol. (BM 649-653)

- Alfonsi Salmeronis Toletani, e Societate Iesv Theologi, Commentarii in Evangelicum Historiam, \& in Acta Apostolorum. Vol. 8. Madrid: Luis Sánchez, 1600. Fol. (BM 717)

- Alfonsi Salmeronis Toletani, e Societate Iesv Theologi, Commentarii in Evangelicum Historiam, \& in Acta Apostolorum. Vols. 9-12. Madrid: Luis Sánchez, 1601. Fol. (BM 795-798)

Sánchez, Pedro. S.J. Libro del Reyno de Dios, y del camino por do se alcança. Madrid: Luis Sánchez, 1599. 4. (BM 654)

Sánchez Valdés de la Plata, Juan. Coronica y Historia general del hombre, en que se trata del hombre en comun. Madrid: Luis Sánchez, 1598. Fol. (BM 606)

Sandoval, Prudencio de. O.S.B. Cronica del inclito Emperador de España, Don Alonso VII. Madrid: Luis Sánchez, 1600. Fol. (BM 718)

- Primera parte de las Fvundaciones de los Monesterios del glorioso Padre San Benito, que los Reyes de España fundaron y dotaron, desde los tiempos del Santo, hasta que los Moros entraron y destruyeron la tierra.Madrid: Luis Sánchez, 1601. Fol. (BM 799) 
Santa María, Antonio de. O.F.M. Manual o Sumario de la Regla de los frailes Menores. Madrid: Luis Sánchez, 1598. 32º. (BM 607)

Soto, Lázaro de. Tomus primus Commentariorum in Hippocratis libros, quorum numerus sequenti pagella indicabitur. Madrid: Luis Sánchez, 1594. Fol. (BM 458)

Straparola de Carvaggio, Juan Francisco. Honesto y agradable entretenimeinto de Damas y Galanes. Madrid: Luis Sánchez, 1598. (BM 609)

Torres, Pedro de. Libro que trata de la enfermedad de las Bvbas. Madrid: Luis Sánchez, 1600. $4^{\circ}$. (BM 720)

Vallés, Francisco de. Tratado de las agvas Destiladas, Pesos, Y medidas de que los Boticarios deven vsar pornueva ordenança, y mandato de su Magestad, y su Real Consejo. Madrid: Luis Sánchez, 1592. $8^{\circ}$. (BM 397)

Vega Carpio, Lope Félix de. Arcadia, Prosas, y Versos de Lope de Vega Carpio, Secretario del Marques de Sarria. Madrid: Luis Sánchez, 1599. 8. (BM 663)

- Isidro.Madrid: Luis Sánchez, 1599. $8^{\circ}$. (BM 664)

Vega, Garcilaso de la.Obras del Excelente Poeta Garci Lasso de la Vega. Madrid: Luis Sánchez, 1600. 12. (BM 692)

Verdugo y Sarria, Pedro. O.P. Libro de los Mysterios de la Missa. Madrid: Luis Sánchez, 1594. $4^{\circ}$. (BM 459)

Villegas y Selvago, Alonso de. Vida de Isidro Labrador, cuyo cuerpo está en la Iglesia Parroquial de San Andrés de Madrid, escrita por el Maestro Alonso de Villegas, toledano. Madrid: Luis Sánchez, 1592. $8^{\circ}$. (BM 398)

Yerba, Melchor de. O.F.M. Libro llamado Refugium infirmorum, muy util y prouechoso para todo genero de gente, En el qual se contienen muchos avisos espirituales para socorro de los afligidos enfermos, y para ayudar ábien morir á los que estan el lo ultimo de su vida. Madrid: Luis Sánchez, 1593. 8. (BM 425)

Yepes, Diego de. O. Her. Historia particular de la persecución de Inglaterra, y de los martirios mas insignes que en ella ha hauido, desde el año del Señor. Madrid: Luis Sánchez, 1599. $8^{\circ}$. (BM 667)

Zamudio de Alfaro, Andrés. Orden para la cvra y preservacion de las secas y carbuncos. Madrid: Luis Sánchez, 1599. $8^{\circ}$. (BM 668)

Orden para la cura y preservacion de la Viruelas. Madrid: Luis Sánchez, 1599. $8^{\circ}$. (BM 669) 


\subsection{Valladolid Era $(1602-1606)$}

\subsubsection{Printed in Madrid}

\begin{tabular}{|c|c|c|c|c|c|}
\hline \multicolumn{6}{|c|}{$\begin{array}{l}\text { Printing Tendencies in the Madrid Branch of } t \\
\text { Format Production }\end{array}$} \\
\hline & & Size & Amount Produced & Language & Amount \\
\hline & & Folio & 12 & Castilian & 29 \\
\hline \multicolumn{2}{|c|}{ Annual Production } & Quarto & 22 & Latin & 14 \\
\hline Year & Amount & Octavo & 6 & \multirow{2}{*}{\multicolumn{2}{|c|}{ Stylistic Production }} \\
\hline 1602 & 4 & Sextodecimo & 1 & & \\
\hline 1603 & 10 & \multirow{2}{*}{\multicolumn{2}{|c|}{ Production by Order }} & Type of Work & Amount \\
\hline 1604 & 13 & & & Ecclesiastic & 10 \\
\hline 1605 & 8 & Order & Number of Writers & Devotional & 20 \\
\hline 1606 & 8 & Jesuits & 5 & Philosophical & 7 \\
\hline Total & 43 & Merceds & 3 & Utilitarian & 5 \\
\hline & & Franciscans & 2 & Entertainment & 1 \\
\hline$!$ & & Augustinians & 2 & & \\
\hline & & Minims & 1 & & \\
\hline
\end{tabular}

Iurium, ac praeeminentiarum Compendium, \& allegatio pro Ecclesia Sanctae Mariae Maioris, \& de Pilari. Madrid: Luis Sánchez, 1606. 4. (BM 930)

Libro de las Honras que hizo el Colegio de la Compañía de Iesvs de Madrid, a la M.C. de la Emperatriz dona Maria de Austria, fundadora del dicho Colegio, que se celebraron a 21. Madrid: Luis Sánchez, 1603. 4². (BM 836)

Primera parte, del tesoro de divina poesia, donde se contienen varias obras de deuocion de diuersos autores, cuyos titulos se veran a la buelta de la hoja. Madrid: Luis Sánchez, 1604. $8^{\circ}$. (BM 894)

Relacion de las Fiestas que la Imperial Ciudad de Toledo hizo al nacimiento del Principe N.S. Felipe IIII. Madrid: Luis Sánchez, 1605. 4. (BM 917)

Sumario del estado en que estan las rentas del Reyno de Portugal, y situacion que ay en ellas este ano de 1606. Madrid: Luis Sánchez, 1606. Fol. (BM 952)

Tratados espiritvales de algvnos Santos antiguos. Madrid: Luis Sánchez, 1603. $8^{\circ}$. (BM 851)

Vota, et Motiva sententiae latae pro Priore, \& Canonicis Angelicae Ecclesiae B. Mariae Maioris de Pilari, in Curia illustrissimi domini Iustitiae Aragonum. Madrid: Luis Sánchez, 1606. $4^{\circ}$. (BM 954) 
Augustine. Las confessiones del glorioso Dotor de la Iglesia San Agvstin. Trans. Pedro de Ribadeneyra. Madrid: Luis Sánchez, 1603. 16². (BM 829)

Arias, Francisco. S.J. Aprovechamiento Espiritval. Madrid: Luis Sánchez, 1603. 4². (BM 830)

Bocangelino, Nicolao. De Febribus, morbisque malignis, \& pestilentia, earumque causis, praeservatione \& curatione. Madrid: Luis Sánchez, 1604. 4. (BM 861)

Bovistau, Pedro. Historias prodigiosas y maravillosas De diuersos sucessos acaecidos en el Mundo. Madrid: Luis Sánchez, 1603. $8^{\circ}$. (BM 832)

Collantes y Avellaneda, Santiago de. Commentariorum Pragmaticae in favorem rei frumentariae, \& agricolarum, \& rerum quae agriculturae, destinate sunt, libri tres. Madrid: Luis Sánchez, 1606. 4. (BM 931)

Florencia, Jeronimo de. S.J. Sermon que predico el Padre Geronimo de Florencia, religioso de la Compañía de Jesus, a las honras de la Sacra Cesarea Magestad de la Emperatriz Dona Maria que como a su Fundadora le hizo el Colegio de la Compañia Iesus de Madrid, ano de mil y seyscientos y tres. Madrid: Luis Sánchez, 1604. $4^{\circ}$. (BM 865)

González, Cristóbal. O.Mer. Consideraciones del agradecimiento christiano. Madrid: Luis Sánchez, 1606. 4. (BM 937)

Gregory XIII. S.D.M. Gregorii XIII. Bvlla exemptionis, \& Sedi Apostolicae immediatae subiectionis, Ecclesiae B. Mariae de Pilari, Canonicorum Regularium, Ordinis $S$. Augustini Caesaraugust. Madrid: Luis Sánchez, 1606. 4º (BM 938)

López Pinciano, Alonso. El Pelayo del Pinciano. Madrid: Luis Sánchez, 1605. $8^{\circ}$. (BM 908)

Madrigal, Juan Bautista de. O.F.M. Homiliario Evangelico en que se tratan diversas materias espirituales, y lugares notables de Escritura, en grande beneficio de las almas, y reformacion de costumbres deprauadas, $y$ abusos introduzios en el mundo. Madrid: Luis Sánchez, 1602. 4. (BM 811)

Malón de Chaide, Pedro. O.S.A. Libro de la conversaion de la Magdalena. Madrid: Luis Sánchez, 1604. (BM 874)

Montesino,Ambrosio. Epistolas y Evangelios. Madrid: Luis Sánchez, 1603. (BM 843)

Morales, Gaspar de. Libro de las virtvdes y propiedades maravillosas de las piedras preciosas. Madrid: Luis Sánchez, 1605. $8^{\circ}$. (BM 911) 
Murcia de la Llana, Francisco. Selecta circa libros Aristotelis de Anima subtilioris doctrine que in Complutensi Academia versatur, miro quodam ordine disposita, $\&$ in dilucidam methodum redacta. Madrid: Luis Sánchez, 1604. 4. (BM 878)

-Selecta circa libros Aristotelis de Coelo svbtilioris doctrinae, quae in Complutensi Academia versatur, miro quodam ordine disposita, \& in dilucidam methodum redacta. Madrid: Luis Sánchez, 1604. 4. (BM 879)

- Selecta circa libros Aristotelis de Generatione, et corruptione, subtilioris doctrinae, quae in Complutensi Academia versatur, miro quodam ordine disposita, \& in dilucidam quadam methodum redacta. Madrid: Luis Sánchez, $1604.4^{\circ}$. (BM 880)

- Selecta de Ratione Terminorum ad Dialectiam Aristotelis subtilioris doctrinae, quae in Complutensi Academia versatur, miro quodam ordine disposita, \& in dilucidam methodum redacta. Madrid: Luis Sánchez, 1604. 4. (BM 881)

Murillo, Diego. O.F.M. Discursos predicables sobre los Evangelios que canta la Iglesia en los Domingos y Ferias, desde la Septuagessima, hasta la Resurreccion del Señor. Madrid: Luis Sánchez, 1602. 4. (BM 818)

Oña, Pedro de. O.Mer. Primera parte de las Postrimerias del hombre compvesta por el Maestro D. Fr. Pedro de Oña Obispo de Veneçuela, del Consejo de su Magestad. Madrid: Luis Sánchez, 1603. Fol. (BM 845)

Plaza de Fresneda, Cristóforo. Commentaria in octo libros Aristotelis de Physica Avscvltatione. Madrid: Luis Sánchez, 1604. 4 . (BM 886)

Ribadeneyra,Pedro de. S.J. Libro de Vidas de Santos, que communmente llaman Extravagantes; porque la santa Yglesia no reza dellos en el Breviario Romano. Madrid: Luis Sánchez, 1604. Fol. (BM 888; JS 1549)

-Vida de Christo y de su Madre Santissima. Madrid: Luis Sánchez, 1604. Fol. (BM 889)

-Obras del Padre Pedro de Ribadeneyra. Agora de nueuo reuistas y acrecentadas. Madrid: Luis Sánchez, 1605. Fol. (BM 919; JS 1495)

- Tratado, en el qual se da razon del Institutio de la Religion de la Compania de Iesvs. Madrid: Luis Sánchez, 1605. 4. (BM 920)

Ribera, Hernando de.O.Mer. Sermon predicado el Domingo infra octavas de la Epifania, en la yglesia de la Compañía de Iesus, el primer dia del Capitulo Prouincial que celebraron en la villa de Madrid los padres de nuestra Señora de la Merced, de la Prouincia de Castilla. Madrid: Luis Sánchez, 1606. 4º (BM 948) 
Rodríguez, Manuel. Obras Morales en Romance, Compvestas por el Padre Fray Manuel Rodriguez Lusitano, Lector en Theologia. Madrid: Luis Sánchez, 1602. Fol. (BM 822)

Rubio, Antonio. Commentarii in octo libros Aristotelis de Physico auditu, una cum dubrijs, \& quaestionibus hac tempestate agistari solitis. Madrid: Luis Sánchez, 1605. Fol. (BM 922)

Salmerón, Alfonso. S.J. Alfonsi Salmeronis Tolentani, Societatis Iesu Theologi, Comentarii in omnes Epistolas B. Pauli, \& Canonicas. 4 vols. Madrid: Luis Sánchez, 1602. Fol. (BM 823)

Sánchez, Tomas. S.J. Tomus Secundus Dispvtationvm de Sancto Matrimonii Sacramento. 2 vols. Madrid: Luis Sánchez, 1605. Fol. (BM 923)

Solis, Feliciano de. Appendix ad priores Commentarios de Censibvs, sev Secundus tomus. Madrid: Luis Sánchez, 1605. Fol. (BM 925)

Valderrama, Pedro de. O.S.A. Exercicios espiritvales para todos los dias de la Quaresima. Madrid: Luis Sánchez, 1604. 4. (BM 895)

Valles, Francisco de. Cartas familiares de moralidad, escritas por el Licenciado don Francisco de Valles, natural de la villa de Madrid. Madrid: Luis Sánchez, 1603. $8^{\circ}$. (BM 853)

Vega, Alonso de. O.Min. Svma, llamada nveva Recopilacion, y Practica del Fvero interior, vtilissima para Confessores y penitentes, con varias resoluciones de casi innumerables casos de conciencia, tocantes a todas las materias Teologas, Canonicas, y Iuridicas, conforme a la doctrina de los Santos, y mas graues Autores, antiguos y modernos. Madrid: Luis Sánchez, 1606. 2 vols. Fol. (BM 953)

Vega, Pedro de la. Declaracion de los siete Psalmos Penitenciales. Madrid: Luis Sánchez, 1603. 2 vols. $4^{\circ}$. (BM 854)

Villegas y Selvago, Alonso de. Vitoria y Trivnto de Iesv Christo, y libro en que se escriven los Hechos y milagros que hizo en el mundo este Senor y Dios nuestro, doctrina que predico, preceptos, y consejos que dio. Madrid: Luis Sánchez, 1603. Fol. (BM 858)

Zamora, Lorenzo de. Monarquia mistica de la Yglesia, hecha de hieroglyficos, sacados de hymanas y divinas letras. Madrid: Luis Sánchez, 1604. 4. (BM 900) 


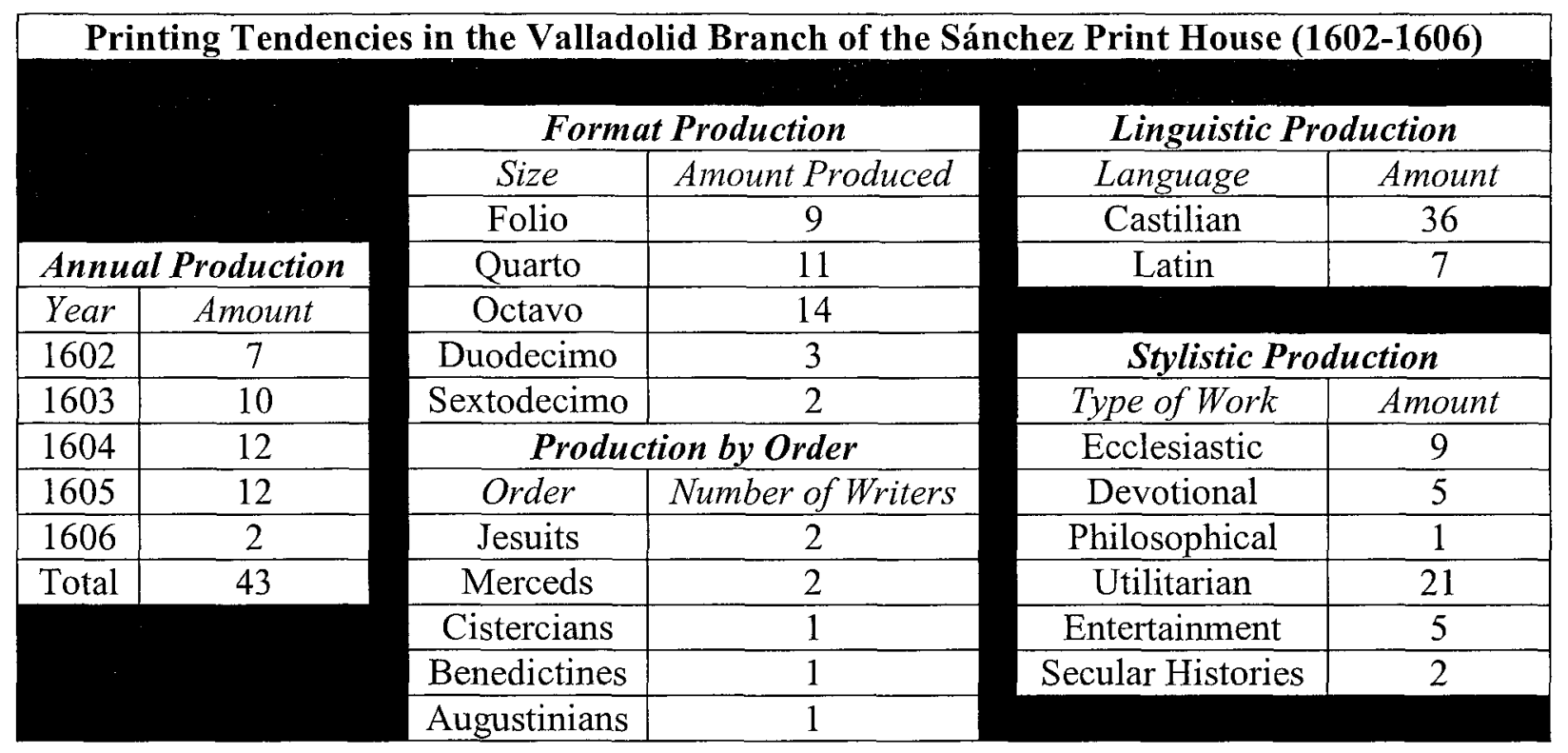

Compilacion de las Leyes Capitvlares de la Orden de la Cavalleria de Santiago del España. Valladolid: Luis Sánchez, 1605. 4 . (CIV 490)

Definiciones de la Orden y Cavalleria de Calatrava. Valladolid: Luis Sánchez, 1605. Fol. (CIV 497)

Del Memoiral que la Duquesa de Medina de Rioseco tiene dado al Rey sobre el desempeño de la casa del Almirante de Castilla. Valladolid: Luis Sánchez, 1605. (CIV 493)

Dos discursos en que se defiende la venida y predicacion del Apostol Santiago en España.Valladolid: Luis Sánchez, 1605. 8. (CIV 489)

En que se manda guardar la Ley que dispone que los Alcades entregadores se acompañen con las justicias ordinarias en la determinación de las causas. Valladolid: Luis Sánchez, 1602. $4^{\circ}$. (CIV 420)

En que se pone la forma que desde la data della en adelante se ha de guardar para poner cambios y Bancos públicos, assi en esta Corte como en las demás partes destos Reynos. Valladolid: Luis Sánchez, 1602. 4. (CIV 421)

En que se svbe el precio del trigo a diez y ocho Reales la hanega y la ceuada a nueue Reales. Valladolid: Luis Sánchez, 1605. Fol. (CIV 502) 
Generales de las Cortes del ano de mil y quinientos y noventa y ocho, fenecidas en el de seiscientos y uno y publicadas en el de seiscientos y quarto. Valladolid: Luis Sánchez, 1604. 4 . (CIV 449)

Generales de las Cortes del ano de mil y quinientos y noventa y dos, fenecidas en el de noventa y ocho; y uno y publicadas en el de seyscientos y quarto. Valladolid: Luis Sánchez, 1604. $4^{\circ}$. (CIV 450)

Para que los registros de los Escriuanos Reales, que residen en la Corte de Su Magestad y en las Chancillerias. Valladolid: Luis Sánchez, 1604. Fol. (CIV 476)

Que el Capitan Pedro Seuil de Guarga dirigió al Rey exponiéndole las razones que habla para emprender una expedición espan, Cochinchina y aun la China. Valladolid: Luis Sánchez, 1603. (CIV 438)

Varias pragmáticas del Reyno hasta el año 1591.Valladolid: Luis Sánchez, 1602. (CIV 419)

La vida del Lazarillo de Tormes y de sus fortunas y adversidades. Valladolid: Luis Sánchez, 1603. $12^{\circ}$. (CIV 435)

Alfaro, Francisco de. Don Francisci de Alfaro Regii in Argentina Cancelaria regnorum Pirv. Fiscalis, Procvratoris, Tractatvs de Officio Fiscalis. Valladolid: Luis Sánchez, 1606. Fol. (CIV 514)

Bravo, Agustino. Las definiciones de la Orden de Caballeria de Calatrava. Valladolid: Luis Sánchez, 1603. Fol. (CIV 430)

Cairasco de Figueroa, Bartolomé. Templo militante trivmphos de virtudes, destividades, y vidas de Santos. Valladolid: Luis Sánchez, 1602. $8^{\circ}$. (CIV 407)

- Templo militante Trivnphos DE virtudes Festividades y vidas DE santos. Valladolid: Luis Sánchez, 1603. (CIV 431)

[Covarrubias, Antonio de.] Información en derecho de D. Gomez Dauila, Marqués de Velada sobre el Estado de Villatoro con Don Henrique Davila que a este pleyto se cpuso. Valladolid: Luis Sánchez, 1602. Fol. (CIV 414)

Espinosa, Pedro de. Primera parte de las Flos de poetas ilustres de España, dividida en dos libros. Valladolid: Luis Sánchez, 1605. 4 . (CIV 490)

Freitas, Serafín. O.Mer. Repetitionem in cap. Sacris.Valladolid: Luis Sánchez, 1604. Fol. (CIV 453) 
González de Critana, Juan. O.S.A. Libro de la Archicofradia de la cinta de San Agustín y Santa Monica y de las indulgencias y provilegios que gozan los cotrades della y de su fundación y Bulas. Valladolid: Luis Sánchez, 1604. 16º. (CIV 458)

Gracian Dantisco, Lucas. Galateo español agora nueuamente impresso y enmendado...Y la vida de Lazarillo de Tormes castigado. Valladolid: Luis Sánchez, 1603. 12. (CIV 434)

Guerrero, Fernan. S.J. Relacion anual de las cosas que han hecho los Padres de la Compañia de Jesus en la India Oriental y Japon en los años 600 y 601 y del progreso de la conversión y christianidad de aquellas partes. Valladolid: Luis Sánchez, 1604. $8^{\circ}$. (CIV 462)

Isla, Lázaro de. Breve tratado de la Artilleria y fabrica de ella y instrumentos de fuego. Valladolid: Luis Sánchez, 1603. $8^{\circ}$. (CIV 436)

León, Andrés de. Practica de morbo Gallico en el cual se contiene el origen y conocimiento desta efermedad y el mejor modo de curarla.Valladolid: Luis Sánchez, 1605. $8^{\circ}$. (CIV 494)

- Tratados de Medicina, Cirugia y Anatomia por el Dr. Andres de Leon.Valladolid: Luis Sánchez, 1605. $8^{\circ}$. (CIV 495)

Madrigal, Miguel de. Segunda parte de Romancero general y flor de diversa poesia.Valladolid: Luis Sánchez, 1605. 4 . (CIV 496 and 505)

Matienzo, Juan. Dialogus Relatoris et advocati Pintiani Senatus in quo variahim inde proponuntur et longe controvertuntur ad Renunciatorum advocatorum et indicum numera eorumque. Valladolid: Luis Sánchez, 1604. 4․ (CIV 465)

Medrano, Don García de. La Regla y esta blecimientos de la Caualleria de Santiago del Espada. Valladolid: Luis Sánchez, 1603. Fol. (CIV 437)

Mercado, Luis. Tomus secundus, Operum Ludovici Mercati a Cubiculo Philppi Tertii. Valladolid: Luis Sánchez, 1605. $4^{\circ}$. (CIV 498)

Monter de la Cueva, Martín de. Juris responsum in suplicatione interposita.Valladolid: Luis Sánchez, 1602. Fol. (CIV 417)

Núñez de Guzmán, Hernán. Refranes o proverbios en romance que nuevamente coligio y gloso el Comendador Hernan Nuñez de Guzman. Valladolid: Luis Sánchez, 1602. $12^{\circ}$. (CIV 418)

Obregón Cereceda, Antonio de. Discursos sobre la filosofia Moral de Aristoteles recogidos de diversos autores. Valladolid: Luis Sánchez, 1603. $8^{\circ}$. (CIV 440) 
Pérez de Herrera, Cristóbal. Defensa de las criaturas de tierna edad, y algunas dudas y adueriencias cerca de la curación y conseruacion de su salud. Valladolid: Luis Sánchez, 1604. 16. (CIV 471)

- Elogio a las esclarecidas virtvdes de la C.R.M. del Rey N.S. Don Felipe II que esta en el cielo, y de su exemplar y Christianissima muerte y carta oratoria al poderosissimo Rey de las Espanas y Nuevo Mundo D. Felipe III nuestro senor sy muy amado hijo. Valladolid: Luis Sánchez, 1604. 4. (CIV 470)

- Clipeus Pverorvm sive de eorum curatione immutanda nec non valetudine tuenda animadversiones aliquot. Valladolid: Luis Sánchez, 1604. 8. (CIV 472)

Pérez de Nájera, Francisco. Ortographia Castellana Dividida en primera y segunda parte a modo de Dialogo entre dos niños de la escuela. Valladolid: Luis Sánchez, 1604. $8^{\circ}$. (CIV 473)

San Román, Antonio de. O.S.B. Historia General de la India Oriental. Valladolid: Luis Sánchez, $1603.8^{\circ}$. (CIV 443)

Santiago, Hernando de. O.Mer. Consideraciones sobre todos los Evangelios de los Domingos y ferias de quaresma. Valladolid: Luis Sánchez, 1606. $8^{\circ}$. (CIV 521)

Savariego de Santana, Gaspar de. O.Cist. Libro de la beriada de los hechos de Scipion Africano en estas partes de España. Valladolid: Luis Sánchez, 1603. $8^{\circ}$. (CIV 444)

Toledo, Francisco. S.J. Instrvccion de Sacerdotes, y suma de casos de conciencia. Valladolid: Luis Sánchez, 1605. 4 . (CIV 507)

Vazquez Marmol, Juan. Arte y Reglas para aprendar a rezar el Oficio diuino, según el Breuiario reformado, y para entender el computo y Calendario. Valladolid: Luis Sánchez, 1605. $8^{\circ}$. (CIV 511)

Zamora,Lorenzo de. Discursos sobre los misterios que en la quaresma se celebran. Valladolid: Luis Sánchez, 1604. 8. (CIV 484) 
4.3 Post-Valladolid Era (1607-1611)



Alegacion en derecho por Doña Francisca Colon de Toledo, sobre la sucesión en possession del Estado y Ducado de Veragua. Madrid: Luis Sánchez, 1608. Fol. (BM 984)

El Ivramento que la Señora Infanta doña Ana, por si, y en nombre del señor Infante don Carlos, y la señora Infanta doña Maria sus hermanos hizieron al Principe don Felipe nuestro señor. Madrid: Luis Sánchez, 1608. Fol. (BM 1006)

Difiniciones y Establecimientos de la orden y Cavalleria de Alcantara. Madrid: Luis Sánchez, 1609. Fol. (BM 1027)

Manera de rezar sus horas los Comendadores y Caballeros de la Orden de Alcantara, y la Regla de San Benito. Madrid: Luis Sánchez, 1609. 8. (BM 1028)

Augustine. Meditaciones, Soliloquios, y Manual. Madrid: Luis Sánchez, 1608. (BM 983)

Ávila, Esteban de. S.J. Tratado de Domicilio. Madrid: Luis Sánchez, 1609. $8^{\circ}$. (BM 1031)

Barona de Valdivielso, Pedro. O.F.M. Hospicio de S. Francisco, y Espeio de bienhechores de las Religiones. Madrid: Luis Sánchez, 1609. 4. (BM 1032) 
Bavia, Luis de. Tercera Parte de la Historia Pontifical y Catolica, Compvesta y ordenada por el D. Luis de Brauia, Capellan del Rey nuestro señor, en su Real Capilla de Granada.Madrid: Luis Sánchez, 1608. Fol. (BM 991)

Bermúdez de Pedraza, Francisco. Antigvedad y Excelencias de Granada. Madrid: Luis Sánchez, 1608. 4. (BM 992)

Cabrera, Pedro de. O.Her. Fratris Petri de Cabrera, Cordvbensis, Sacrae Theologiae Magistri, ex ordine Divi Hieronymi, de Sacramentis in genere de auxilio praeuio, \& de Baptismo. Madrid: Luis Sánchez, 1611. Fol. (BM 1124)

Cabrera de Córdova, Luis. De Historia, para enterderla y escrivirla. Madrid: Luis Sánchez, 1611. $4^{\circ}$. (BM 1125)

Cayrasco de Figueroa, Bartolomé. Terecera parte del Templo militante, festividades, y vidas de Santos, declaracion y triunfos de svs virtvdes, y partes que en ellos resplandecieron. Madrid: Luis Sánchez, 1609. Fol. (BM 1035)

Cetina, Melchor de. O.F.M. Discvrsos sobre la vida y milagros del glorioso padre san Diego, de la Orden del Serafico padre S. Francisco. Madrid: Luis Sánchez, 1609. $4^{\circ}$. (BM 1037)

Covarrubias Orozco, Sebastián de. Emblemas morales de Don Sebastian de Couarrubias Orozco, Capellan del Rey N.S. Maestrescuela, y Canonigo de Cuenca, Consultor del Santo Oficio. Madrid: Luis Sánchez, 1610. 4². (BM 1088)

-Tesoro de la Lengva Castellana, o Española.Madrid: Luis Sánchez, 1611. Fol. (BM 1130)

Davila, Sancho. De la veneracion que se debe a los cverpos de los Sanctos y á sus Reliquias y de la singular con que se a de adorar el cuerpo de Iesu Christo nuestro Señor en el sanctissimo Sacramento. Madrid: Luis Sánchez, 1611. Fol. (BM 1132)

Fonseca, Cristóbal de. O.S.A. Qvarta Parte de la Vida de Christo S.N. que trata de sv dotrina. Madrid: Luis Sánchez, 1611. Fol. (BM 1136)

Fuente Pierola, Hieronymo de la. Fons \& speculum claritatis, per quem disversimodé, res etiam, quae observandae de Medicinarum rectificatione purgantium ob artis beneficia, praecipueque lotionis secundum Joannem Mesuem clarissime collucent, \&. Madrid: Luis Sánchez, 1609. Fol. (BM 1039)

García, Pablo. Orden que comvnmente se gvarda en el Santo Oficio de la Inquisicion, acerca del procesar en las causas que en el se tratan, conforme á lo que está proueydo por las instruciones antiguas y nueuas. Madrid: Luis Sánchez, 1607. $4^{\circ}$. (BM 966) 
González, Cristóbal. O.Mer. Consideraciones sobre el Psalmo ciento y treinta y tres. Madrid: Luis Sánchez, 1609. 4. (BM 1040)

Hernández Blasco, Francisco. Universal Redencion, Passion, Mverte, y Resvrrecion de nuestro Redento Iesu Cristo, y angustias de sus santissima Madre. Madrid: Luis Sánchez, 1609. $4^{\circ}$. (BM 1048)

Herrera y Tordesillas, Antonio de. Informacion en el hecho, y relación de lo que passo en Milan en las competencias, entre las jurisdicciones Eclesiastica, y Seglar, desde el año de 1595, hasta el de 1598. Madrid: Luis Sánchez, 1609. (BM 1044)

López, Pedro. Glossas para declaración de algunas de las Rubricas, Ritus, y Cermonias del Missal de Clemente VIII. Madrid: Luis Sánchez, 1607. 8. (BM 968)

Mariana, Juan de. S.J. Historia general de España. Madrid: Luis Sánchez, 1608. 2 vols. Fol. (BM 1010)

Marieta, Juan de. O.P. Historia de los milagros de Nuestra Señora del Rosario que está en el convento de Vitoria. Madrid: Luis Sánchez, 1611. $8^{\circ}$. (BM 1143)

Martínez Motiño, Francisco. Arte de Cozina, pasterleria, bizcocheria y Conserveria. Madrid: Luis Sánchez, 1611. 12². (BM 1144)

Ortiz Lucio, Francisco. O.F.M. Mistica Theologia, y Tratado de Sacramentos, y remedios contra el pecado, y consuelo del pecador. Madrid: Luis Sánchez, 1608. 16². (BM 1012)

-De los quatro Novissimos y remate de la vida humana. Madrid: Luis Sánchez, 1608. $8^{\circ}$. (BM 1013)

-Svma, Compendio, Recopilacion, y Manval de todoas las Sumas, que comúnmente andan. Madrid: Luis Sánchez, 1610. 4. (BM 1106)

—De los quatro Novissimos y remate de la vida humana. Madrid: Luis Sánchez, 1610. $8^{\circ}$. (BM 1107)

Oviedo,Luis de. Metodo de la colección y reposicion de las medicinas simples y de su corrección y preparación. Madrid: Luis Sánchez, 1609. Fol. (BM 1051)

Pacheco, Baltasar. O.F.M. Espeio de Sacerdotes, y de todos los ministros de la hierarchia Eclesiastica. Madrid: Luis Sánchez, 1611. 4. (BM 1147)

.Compendio de servir al Altar el ministro en la Miza rezada. Madrid: Luis Sánchez, 1611. 16². (BM 1148) 
Pacheco de Narvaez, Luis. Cien conclusiones o formas de saber la verdadera destreza fundada en ciencia, y diez y ocho contradicciones á las de la comun. Madrid: Luis Sánchez, 1608. Fol. (BM 1014)

Pérez Cascales de Guadalajara, Francisco. Liber de affectionibus pverorvm, vna cvm tractav de morbo illo vvlgariter Garrotillo appellato, cum duabus Quaestionibus. Madrid: Luis Sánchez, 1611.4. (BM 1150)

Pérez de Herrera, Cristóbal. Al Catolico y Poderosissimo Rey de las Españas, y de Nueuo Mundo, don Felipe III, nuestro señor, que Dios prospere, y nos guarde muchos años. Madrid: Luis Sánchez, 1608. 4. (BM 1016)

Ribadeneyra, Pedro de. S.J. Manval de Oraciones, para el vso y aprouechamiento de la gente deuota. Madrid: Luis Sánchez, 1607. 16². (BM 977)

- Relacion de lo que ha svcedido en el negocio de la Canonizacion del bienauenturado P. Ignacio de Loyola, fundador de la Religion de la Compañía de Iesvs. Madrid: Luis Sánchez, 1609. $8^{\circ}$. (BM 1067)

- Segunda parte del Flos Sanctorum, o Libro de las Vidas de los Santos. En la qual se contienen las Vidas de muchos Santos de todos estados, que communmente llaman Extrauagantes. Madrid: Luis Sánchez, 1609. Fol. (BM 1068; JS 1550)

___ Flos sanctorum o libro de las vidas de los santos. Madrid: Luis Sánchez, 1610. Fol. (BM 1114; JS 1541)

Tamayo, Francisco. O.Min. Primera Parte de las grandezas y meioras de Christo, en que por discursos se tratan los misterios mayores de su Concepcion, vida y muerte. Madrid: Luis Sánchez, 1610. 4. (BM 1116)

Teresa de Jesús. O.C.D. Los libros de la B. Madre Teresa de Iesvs. Madrid: Luis Sánchez, $1611.4^{\circ} .(\mathrm{BM} 1157)$

Vega, Alonso de. O.Min. Epitome o Compendio de la Svma llamada Nveva Recopilacion y pratica del fuero interior del P.F. Alonso de Vega, de la sagrada Religion de los Minimos del gloriosissimo Patriarca san Francisco de Paula, y en ella el mas minimo.Madrid: Luis Sánchez, 1610. 4. (BM 1120)

Vega, Diego de la. Empleo y exercicio santo, sobre los Evangelios de las Doctrinas despues de Pentecostes. Madrid: Luis Sánchez, 1607. 4. (BM 979) 


\section{APPENDIX 5: SAINTS OF VARIOUS FLOS SANCTORUM}

AV - Alonso de Villegas

MR - Martyrologium Romanum

PR - Pedro de Ribadeneyra

PV - Pedro de la Vega

\begin{tabular}{|c|c|c|c|c|c|c|c|c|}
\hline NAME & $\begin{array}{c}\text { PV } \\
(1556)\end{array}$ & $\begin{array}{c}\text { MR } \\
(1584)\end{array}$ & $\begin{array}{c}\mathrm{AV} \\
(\mathbf{1 5 8 8})\end{array}$ & $\begin{array}{c}\text { PR } \\
(1599)\end{array}$ & $\begin{array}{c}\text { PR } \\
(1601)\end{array}$ & $\begin{array}{c}\text { PR } \\
(1604)\end{array}$ & $\begin{array}{c}\text { PR } \\
(1609)\end{array}$ & $\begin{array}{c}\mathrm{AV} \\
(1609)\end{array}$ \\
\hline 4 Crowned Ones & & $\checkmark$ & $\checkmark$ & & $\checkmark$ & $\checkmark$ & & \\
\hline 5 Martyrs & & $\checkmark$ & $\checkmark$ & & & & & \\
\hline 7 Brothers & & $\checkmark$ & $\checkmark$ & & $\checkmark$ & $\checkmark$ & & \\
\hline 7 Sleepers & & $\checkmark$ & $\checkmark$ & & & & $\checkmark$ & \\
\hline 12 Martyrs & & $\checkmark$ & $\checkmark$ & & $\checkmark$ & & & \\
\hline 40 Martyrs & $\checkmark$ & $\checkmark$ & $\checkmark$ & $\checkmark$ & & $\checkmark$ & & \\
\hline 11,000 Virgins & $\checkmark$ & $\checkmark$ & $\checkmark$ & & $\checkmark$ & & & \\
\hline Aaron & & $\checkmark$ & & & & & & $\checkmark$ \\
\hline Abdon and Sennen & $\checkmark$ & $\checkmark$ & $\checkmark$ & & $\checkmark$ & $\checkmark$ & & \\
\hline Abel & & & & & & & & $\checkmark$ \\
\hline Abildus & & $\checkmark$ & & & & & $\checkmark$ & \\
\hline Abraham & & $\checkmark$ & & & & & $\checkmark$ & $\checkmark$ \\
\hline Abundius & & $\checkmark$ & $\checkmark$ & & & & & \\
\hline Acacius & & $\checkmark$ & $\checkmark$ & $\checkmark$ & & & & \\
\hline Acisclus and Victoria & $\checkmark$ & $\checkmark$ & $\checkmark$ & & & $\checkmark$ & $\checkmark$ & \\
\hline Acursius and his Companions & & $\checkmark$ & & & & & $\checkmark$ & \\
\hline Adam and Eve & & & & & & & & $\checkmark$ \\
\hline Adelbert of Prague & & $\checkmark$ & & & & & $\checkmark$ & \\
\hline Adelelmo & & $\checkmark$ & $\checkmark$ & & & & & \\
\hline Adrian and Natalia & $\checkmark$ & $\checkmark$ & $\checkmark$ & & $\checkmark$ & $\checkmark$ & & \\
\hline Agapitus & & $\checkmark$ & $\checkmark$ & & $\checkmark$ & $\checkmark$ & & \\
\hline Agatangelus & & $\checkmark$ & & & & & $\checkmark$ & \\
\hline Agatha & $\checkmark$ & $\checkmark$ & $\checkmark$ & $\checkmark$ & & $\checkmark$ & & \\
\hline Agnes & $\checkmark$ & $\checkmark$ & $\checkmark$ & $\checkmark$ & & $\checkmark$ & & \\
\hline Albert, Bishop and Martyr & & $\checkmark$ & & & & & $\checkmark$ & \\
\hline Albert the Carmelite & & $\checkmark$ & $\checkmark$ & & & & $\checkmark$ & \\
\hline Pope Alexander & $\checkmark$ & $\checkmark$ & $\checkmark$ & $\checkmark$ & & $\checkmark$ & & \\
\hline Alexis & $\checkmark$ & $\checkmark$ & $\checkmark$ & & $\checkmark$ & $\checkmark$ & & \\
\hline Amador & & $\checkmark$ & $\checkmark$ & & & & & \\
\hline Ambrose, Archbishop of Milan & $\checkmark$ & $\checkmark$ & $\checkmark$ & & $\checkmark$ & $\checkmark$ & & \\
\hline Amos & & $\checkmark$ & & & & & & \\
\hline Pope Anacletus & & $\checkmark$ & $\checkmark$ & & $\checkmark$ & $\checkmark$ & & \\
\hline Ananias & & $\checkmark$ & $\checkmark$ & & & & & \\
\hline Anastasia & $\checkmark$ & $\checkmark$ & $\checkmark$ & & $\checkmark$ & & & \\
\hline Anastasius & & $\checkmark$ & $\checkmark$ & $\checkmark$ & & $\checkmark$ & & \\
\hline Andronicus and Anatasia & & $\checkmark$ & & & & & $\checkmark$ & \\
\hline Anastiasius, Felix, and Digna & & $\checkmark$ & $\checkmark$ & & & & & \\
\hline Andrew the Apostle & $\checkmark$ & $\checkmark$ & $\checkmark$ & & $\checkmark$ & $\checkmark$ & & \\
\hline Andrew of Fiesoli & & $\checkmark$ & & & & & & \\
\hline Angel the Carmelite & & $\checkmark$ & $\checkmark$ & & & & & \\
\hline Pope Anicetus & & $\checkmark$ & $\checkmark$ & $\checkmark$ & & $\bar{\checkmark}$ & & \\
\hline Anna, mother of Mary & $\checkmark$ & $\checkmark$ & $\checkmark$ & & $\checkmark$ & $\checkmark$ & & \\
\hline Anselm & & $\checkmark$ & $\checkmark$ & & & $\checkmark$ & $\checkmark$ & \\
\hline
\end{tabular}




\begin{tabular}{|c|c|c|c|c|c|c|c|c|}
\hline NAME & $\begin{array}{c}\text { PV } \\
(1556) \\
\end{array}$ & $\begin{array}{c}\mathrm{MR} \\
(1584) \\
\end{array}$ & $\begin{array}{c}\text { AV } \\
(1588) \\
\end{array}$ & $\begin{array}{c}\text { PR } \\
(1599)\end{array}$ & $\begin{array}{c}\text { PR } \\
(1601)\end{array}$ & $\begin{array}{c}\text { PR } \\
(1604) \\
\end{array}$ & $\begin{array}{c}\text { PR } \\
(1609)\end{array}$ & $\begin{array}{c}\mathrm{AV} \\
(1609) \\
\end{array}$ \\
\hline Antony the Anchorite & $\checkmark$ & $\checkmark$ & $\checkmark$ & $\checkmark$ & & $\checkmark$ & & \\
\hline Antony of Florence & & $\checkmark$ & $\checkmark$ & & & $\checkmark$ & $\checkmark$ & \\
\hline Antony the Martyr & $\checkmark$ & $\checkmark$ & $\checkmark$ & & & & & \\
\hline Antony of Padua & $\checkmark$ & $\checkmark$ & $\checkmark$ & $\checkmark$ & & $\checkmark$ & & \\
\hline Apollonaire & $\checkmark$ & $\checkmark$ & $\checkmark$ & & $\checkmark$ & $\checkmark$ & & \\
\hline Apollonia & $\checkmark$ & $\checkmark$ & $\checkmark$ & $\checkmark$ & & $\checkmark$ & & \\
\hline Aquitanicus & & & $\checkmark$ & & & & & \\
\hline Aranasıus & & & & $\checkmark$ & & & & \\
\hline Arcadius & & $\checkmark$ & $\checkmark$ & & & & & \\
\hline Archileus & & $\checkmark$ & & $\checkmark$ & & & & \\
\hline Argirmurus & & $\checkmark$ & $\checkmark$ & & & & & \\
\hline Arsenius & & $\sqrt{ }$ & & & & & $\checkmark$ & \\
\hline Asela & & $\checkmark$ & & & & & $\checkmark$ & \\
\hline Athanasıus & & $\sqrt{ }$ & $\checkmark$ & & & $\checkmark$ & & \\
\hline Attılanus & & $\checkmark$ & $\checkmark$ & & & & & \\
\hline Augustine of Hippo & $\checkmark$ & $\checkmark$ & $\checkmark$ & & $\checkmark$ & $\checkmark$ & & \\
\hline Aurea & & $\checkmark$ & $\checkmark$ & & & & & \\
\hline Aycardo the Abbot & & $\checkmark$ & & & & & $\checkmark$ & \\
\hline Barak and Deborah & & & & & & & & $\checkmark$ \\
\hline Barbara & $\checkmark$ & $\checkmark$ & $\checkmark$ & & $\checkmark$ & $\checkmark$ & & \\
\hline Barlaam and Josephat & & $\checkmark$ & $\checkmark$ & & & $\checkmark$ & $\checkmark$ & \\
\hline Barnabas the Apostle & $\checkmark$ & $\checkmark$ & $\checkmark$ & $\checkmark$ & & $\checkmark$ & & \\
\hline Bartholomew the Apostle & $\checkmark$ & $\checkmark$ & $\checkmark^{\prime}$ & & $\checkmark$ & $\checkmark$ & & \\
\hline Baruch & & & & & & & & $\checkmark$ \\
\hline Basil & $\checkmark$ & $\checkmark$ & $\checkmark$ & $\checkmark$ & & $\checkmark$ & & \\
\hline $\begin{array}{c}\text { Basılides, Cirınus, Nabor, and } \\
\text { Nazarıus }\end{array}$ & & $\checkmark$ & $\checkmark$ & $\checkmark$ & & $\checkmark$ & & \\
\hline Basılisa & & $\checkmark$ & & & & & $\checkmark$ & \\
\hline Bede & & $\checkmark$ & & & & & $\checkmark$ & \\
\hline Benedict of Nursia & $\checkmark$ & $\checkmark$ & $\checkmark$ & $\checkmark$ & & $\checkmark$ & & \\
\hline Bernard of Clairvaux & & $\checkmark$ & $\checkmark$ & & $\checkmark$ & $\checkmark$ & & \\
\hline Bernard Martyr & & $\checkmark$ & $\checkmark$ & & & & & \\
\hline Bernardino of Siena & $\checkmark$ & $\checkmark$ & $\checkmark$ & & & $\checkmark$ & & \\
\hline Bernardo and his Companions & $\checkmark$ & $\checkmark$ & $\checkmark$ & & & & $\checkmark$ & \\
\hline Bibiana & $\checkmark$ & $\checkmark$ & $\checkmark$ & & $\checkmark$ & $\checkmark$ & & \\
\hline Blaise & $\checkmark$ & $\checkmark$ & $\checkmark$ & $\checkmark$ & & $\checkmark$ & & \\
\hline Blaise of Spain & & & $\checkmark$ & & & & & \\
\hline Boaz and Ruth & & & & & & & & $\checkmark$ \\
\hline Bonaventure & $\checkmark$ & $\checkmark$ & $\bar{\checkmark}$ & & $\checkmark$ & $\checkmark$ & & \\
\hline Boniface & $\checkmark$ & $\checkmark$ & $\checkmark$ & $\checkmark$ & & $\checkmark$ & $\checkmark$ & \\
\hline Bonito & & $\checkmark$ & & & & & $\checkmark$ & \\
\hline Braulius & $\checkmark$ & $\checkmark$ & $\checkmark$ & & & $\checkmark$ & $\checkmark$ & \\
\hline Brice & $\checkmark$ & $\checkmark$ & $\checkmark$ & & & & $\checkmark$ & \\
\hline Brigit the Martyr & $\checkmark$ & & $\checkmark$ & & & & & \\
\hline Briget of Sweden & & & $\checkmark$ & & & $\checkmark$ & $\checkmark$ & \\
\hline Brigid of Scotland & & $\checkmark$ & & & & $\checkmark$ & $\checkmark$ & \\
\hline Bruno & & $\checkmark$ & $\checkmark$ & & & $\checkmark$ & $\checkmark$ & \\
\hline Burcadus & & $\checkmark$ & & & & & $\checkmark$ & \\
\hline Pope Calus & & $\checkmark$ & $\checkmark$ & $\checkmark$ & & $\checkmark$ & & \\
\hline Pope Callixtus I & $\checkmark$ & $\checkmark$ & $\checkmark$ & & $\checkmark$ & $\checkmark$ & & \\
\hline Carphorus and Abundrus & & $\checkmark$ & $\checkmark$ & & & & & \\
\hline Carthusıan Martyrs & & $\checkmark$ & $\checkmark$ & & & & & \\
\hline
\end{tabular}




\begin{tabular}{|c|c|c|c|c|c|c|c|c|}
\hline NAME & $\begin{array}{c}\text { PV } \\
(1556)\end{array}$ & $\begin{array}{c}\mathrm{MR} \\
(1584) \\
\end{array}$ & $\begin{array}{c}\mathrm{AV} \\
(\mathbf{1 5 8 8}) \\
\end{array}$ & $\begin{array}{c}\text { PR } \\
(1599) \\
\end{array}$ & $\begin{array}{c}\text { PR } \\
(1601)\end{array}$ & $\begin{array}{c}\text { PR } \\
(1604)\end{array}$ & $\begin{array}{c}\text { PR } \\
(1609)\end{array}$ & $\begin{array}{c}\mathrm{AV} \\
(1609)\end{array}$ \\
\hline Casilda & & & $\checkmark$ & & & & $\checkmark$ & \\
\hline Cassian & & $\checkmark$ & $\checkmark$ & & $\checkmark$ & $\checkmark$ & & \\
\hline Catherine of Alexandria & $\checkmark$ & $\checkmark$ & $\checkmark$ & & $\checkmark$ & $\checkmark$ & & \\
\hline Catherine of Siena & & $\checkmark$ & $\checkmark$ & & & $\checkmark$ & & \\
\hline Catherine of Sweden & & $\checkmark$ & & & & & $\checkmark$ & \\
\hline Cecilia and her Companıons & $\checkmark$ & & $\checkmark$ & & $\checkmark$ & $\checkmark$ & & \\
\hline Celedonius and Emeterius & & & & & & & $\checkmark$ & \\
\hline Centolla and Helena & & $\checkmark$ & $\checkmark$ & & & & & \\
\hline Cerbonıus & $\checkmark$ & $\checkmark$ & & & & & & \\
\hline Cesarius of Arles & & $\checkmark$ & & & & & $\checkmark$ & \\
\hline Chrisantus and Darıus & $\checkmark$ & $\checkmark$ & $\checkmark$ & & $\checkmark$ & & & \\
\hline Christophorus and Levuıgıldo & & $\checkmark$ & $\checkmark$ & & & & & \\
\hline Chrıstına & $\checkmark$ & $\checkmark$ & $\checkmark$ & & $\checkmark$ & $\checkmark$ & & \\
\hline Christopher & $\checkmark$ & $\checkmark$ & $\checkmark$ & & $\checkmark$ & $\checkmark$ & & \\
\hline Clara of Monte Falco & & $\checkmark$ & & & & $\checkmark$ & $\checkmark$ & \\
\hline Clare & $\checkmark$ & & $\checkmark$ & & $\checkmark$ & $\checkmark$ & & \\
\hline $\begin{array}{c}\text { Claudius, Nicostratus, } \\
\text { Sinphorianus, Castorius, and } \\
\text { Simplicius }\end{array}$ & & $\checkmark$ & $\checkmark$ & & $\checkmark$ & $\checkmark$ & & \\
\hline Pope Clement & $\checkmark$ & $\checkmark$ & $\checkmark$ & & $\checkmark$ & $\checkmark$ & & \\
\hline $\begin{array}{l}\text { Clement, Anciranus, } \\
\text { Agatangelus }\end{array}$ & & $\checkmark$ & & & & & $\checkmark$ & \\
\hline Pope Cletus & & $\checkmark$ & $\checkmark$ & $\checkmark$ & & & & \\
\hline Columba & & $\checkmark$ & $\checkmark$ & & & & & \\
\hline Columbanus & & $\checkmark$ & & & & & $\checkmark$ & \\
\hline Cornelius the Centurion & & $\checkmark$ & $\checkmark$ & & & & & \\
\hline Pope Cornelius and Cebrian & $\checkmark$ & $\checkmark$ & $\checkmark$ & & $\checkmark$ & $\checkmark$ & & \\
\hline Cosmas and Damian & $\checkmark$ & $\checkmark$ & $\checkmark$ & & $\checkmark$ & $\checkmark$ & & \\
\hline Crecencia & & $\checkmark$ & & $\checkmark$ & & & & \\
\hline Crispın and Crispınıanus & & $\checkmark$ & $\checkmark$ & & & & & \\
\hline Cristeta & & $\checkmark$ & & & & & $\checkmark$ & \\
\hline Crysogonus & & & $\checkmark$ & & $\checkmark$ & $\checkmark$ & & \\
\hline Cun1gunda & & & & & & & $\checkmark$ & \\
\hline Cyprian & & $\checkmark$ & $\checkmark$ & & $\checkmark$ & $\checkmark$ & & \\
\hline Cyriacus, Largus, etc & $\checkmark$ & $\checkmark$ & $\checkmark$ & & $\checkmark$ & $\checkmark$ & & \\
\hline Cyriacus and Paula & & $\checkmark$ & $\checkmark$ & & & & & \\
\hline Cyril the Hieronymite & & $\checkmark$ & $\checkmark$ & & & $\checkmark$ & $\checkmark$ & \\
\hline Cyril of Alexandria & & $\checkmark$ & $\checkmark$ & & & $\checkmark$ & $\checkmark$ & \\
\hline Cyrinus & & $\checkmark$ & & $\checkmark$ & & & & \\
\hline Cyrus and John & $\checkmark$ & $\checkmark$ & & & & & & \\
\hline Pope Damasus & $\checkmark$ & $\checkmark$ & $\checkmark$ & & $\checkmark$ & $\checkmark$ & & \\
\hline Daniel & & $\checkmark$ & & & & & & $\checkmark$ \\
\hline Kıng David of Israel & & $\checkmark$ & & & & & & $\checkmark$ \\
\hline Dennis and his Companions & $\checkmark$ & $\checkmark$ & & & & & & \\
\hline $\begin{array}{l}\text { Dennis the Areopagite and his } \\
\text { Companions }\end{array}$ & & $\checkmark$ & $\checkmark$ & & $\checkmark$ & $\checkmark$ & & \\
\hline Diego de Alcalá & & & & & $\checkmark$ & $\checkmark$ & & \\
\hline Diego Aleman de Santodomıngo & & & & & & & $\checkmark$ & \\
\hline Diphna & & $\checkmark$ & & & & & $\checkmark$ & \\
\hline Dominic & $\checkmark$ & $\checkmark$ & $\checkmark$ & & $\checkmark$ & $\checkmark$ & & \\
\hline Dominuc of the Causeway & $\checkmark$ & $\checkmark$ & $\checkmark$ & & & & $\checkmark$ & \\
\hline Domınıc of Silos & $\checkmark$ & $\checkmark$ & & & & & $\checkmark$ & \\
\hline
\end{tabular}




\begin{tabular}{|c|c|c|c|c|c|c|c|c|}
\hline NAME & $\begin{array}{c}\text { PV } \\
(1556)\end{array}$ & $\begin{array}{c}\text { MR } \\
(1584)\end{array}$ & $\begin{array}{c}\mathrm{AV} \\
(\mathbf{1 5 8 8 )}\end{array}$ & $\begin{array}{c}\text { PR } \\
(1599) \\
\end{array}$ & $\begin{array}{c}\text { PR } \\
(1601)\end{array}$ & $\begin{array}{c}\text { PR } \\
(1604)\end{array}$ & $\begin{array}{c}\text { PR } \\
(1609)\end{array}$ & $\begin{array}{c}\mathrm{AV} \\
(\mathbf{1 6 0 9 )}\end{array}$ \\
\hline Donatus & $\checkmark$ & $\checkmark$ & $\checkmark$ & & $\checkmark$ & $\checkmark$ & & \\
\hline Dorothy & & $\checkmark$ & $\checkmark$ & $\checkmark$ & & $\checkmark$ & & \\
\hline Dunstan & & $\checkmark$ & & & & & $\checkmark$ & \\
\hline Edita & & $\checkmark$ & & & & & $\checkmark$ & \\
\hline Edmund & & $\checkmark$ & & & & & $\checkmark$ & \\
\hline Edward the Confessor & & $\checkmark$ & & & & & $\checkmark$ & \\
\hline Elesmes & & & $\checkmark$ & & & & & \\
\hline Pope Eleuterus & & $\checkmark$ & $\checkmark$ & $\checkmark$ & & & & \\
\hline Elıah & & $\checkmark$ & & & & & & $\checkmark$ \\
\hline Elısha & & $\checkmark$ & & & & & & $\checkmark$ \\
\hline Elızabeth of Hungary & $\checkmark$ & $\checkmark$ & $\checkmark$ & & & $\checkmark$ & $\checkmark$ & \\
\hline Elizabeth of Portugal & & $\checkmark$ & $\checkmark$ & & & $\checkmark$ & $\checkmark$ & \\
\hline Emerencia & & $\checkmark$ & $\checkmark$ & $\checkmark$ & & $\checkmark$ & & \\
\hline Emeterius and Celedonıus & & & $\checkmark$ & & & & $\checkmark$ & \\
\hline Emencus & & & & & & & $\checkmark$ & \\
\hline Emılıanus & & & $\checkmark$ & & & & & \\
\hline Enecon & & & $\checkmark$ & & & & & \\
\hline $\begin{array}{l}\text { Engratia and the Eighteen } \\
\text { Companions }\end{array}$ & $\checkmark$ & & $\checkmark$ & & & $\checkmark$ & $\checkmark$ & \\
\hline Enoch & & & & & & & & $\checkmark$ \\
\hline Ephrem the Syrian & & $\checkmark$ & & & & & $\checkmark$ & \\
\hline Epıphanıus & & $\checkmark$ & $\checkmark$ & & & $\checkmark$ & $\checkmark$ & \\
\hline Epimachus & & $\checkmark$ & $\checkmark$ & $\sqrt{ }$ & & & & \\
\hline Epitacius and Basileus & & $\checkmark$ & $\sqrt{ }$ & & & & & \\
\hline Equicus & & $\checkmark$ & & & & & $\checkmark$ & \\
\hline Erasmus & $\checkmark$ & $\checkmark$ & $\checkmark$ & $\checkmark$ & & & & \\
\hline Espiridon & & & & & & & $\checkmark$ & \\
\hline Esther & & & & & & & & $\checkmark$ \\
\hline Eteboldus & & $\checkmark$ & & & & & $\checkmark$ & \\
\hline Eucherius & & $\checkmark$ & & & & & $\checkmark$ & \\
\hline Euencius & & $\checkmark$ & & $\checkmark$ & & & & \\
\hline Eugene of Toledo & $\checkmark$ & $\checkmark$ & $\checkmark$ & & & $\checkmark$ & & \\
\hline Eugenia & & $\checkmark$ & $\checkmark$ & & & & & \\
\hline Euphemia and Other Martyrs & & $\checkmark$ & $\checkmark$ & & & & & \\
\hline Euphemua, Martyr of Spain & & $\checkmark$ & $\checkmark$ & & & & & \\
\hline Euphrasıa & & $\checkmark$ & $\checkmark$ & & & & $\checkmark$ & \\
\hline Eulalıa of Barcelona & $\checkmark$ & $\checkmark$ & $\checkmark$ & & & $\checkmark$ & $\checkmark$ & \\
\hline Eulalıa of Merida & & $\checkmark$ & $\checkmark$ & & & $\checkmark$ & $\checkmark$ & \\
\hline Eulogius of Cordova & & $\checkmark$ & $\checkmark$ & & & $\checkmark$ & $\checkmark$ & \\
\hline Eurosia & & & $\checkmark$ & & & & & \\
\hline Eusebius & $\checkmark$ & $\checkmark$ & $\checkmark$ & & $\checkmark$ & $\checkmark$ & & \\
\hline Eusebius of Vercellı & & $\checkmark$ & & & & $\checkmark$ & & \\
\hline Eusemia & $\checkmark$ & & & & $\checkmark$ & $\checkmark$ & & \\
\hline Eutichius & & $\checkmark$ & $\checkmark$ & & & & & \\
\hline Eustachius and his Companıons & $\checkmark$ & $\checkmark$ & $\checkmark$ & & $\checkmark$ & $\checkmark$ & & \\
\hline Pope Evaristus & & $\checkmark$ & & & $\checkmark$ & & & \\
\hline Ezek1el & & $\checkmark$ & & & & & & $\checkmark$ \\
\hline Pope Fabıan & & $\checkmark$ & $\checkmark$ & $\checkmark$ & & & & \\
\hline Fabian and Sebastian & $\checkmark$ & $\checkmark$ & & & & $\checkmark$ & & \\
\hline Facundus and Primitivus & $\checkmark$ & $\checkmark$ & $\checkmark$ & & & & $\checkmark$ & \\
\hline Faith & & & $\checkmark$ & & & & & \\
\hline Fandila & & $\checkmark$ & $\checkmark$ & & & & & \\
\hline
\end{tabular}




\begin{tabular}{|c|c|c|c|c|c|c|c|c|}
\hline NAME & $\begin{array}{c}\text { PV } \\
(1556)\end{array}$ & $\begin{array}{c}\text { MR } \\
(1584)\end{array}$ & $\begin{array}{c}\text { AV } \\
(1588)\end{array}$ & $\begin{array}{c}\text { PR } \\
(1599)\end{array}$ & $\begin{array}{c}\text { PR } \\
(1601)\end{array}$ & $\begin{array}{c}\text { PR } \\
(1604)\end{array}$ & $\begin{array}{c}\text { PR } \\
(1609) \\
\end{array}$ & $\begin{array}{c}\mathrm{AV} \\
(1609) \\
\end{array}$ \\
\hline Faustınus and Jovita & & $\checkmark$ & $\checkmark$ & $\checkmark$ & & $\checkmark$ & & \\
\hline Faustınus, Marcus, and Adrıa & & $\checkmark$ & $\checkmark$ & & $\checkmark$ & & & \\
\hline Faustus, Januaııs, and Martıal & & $\checkmark$ & $\checkmark$ & & & & $\checkmark$ & \\
\hline Felician & $\checkmark$ & $\checkmark$ & & $\checkmark$ & & & & \\
\hline Felıcissımus and Agapıtus & & $\checkmark$ & & & & $\checkmark$ & & \\
\hline Felicity and her Sons & $\checkmark$ & $\checkmark$ & $\checkmark$ & $\checkmark$ & & $\checkmark$ & & \\
\hline Felix the Martyr & & $\checkmark$ & $\checkmark$ & & & $\checkmark$ & & \\
\hline Felix the Presbyter & & $\checkmark$ & $\checkmark$ & $\checkmark$ & & & & \\
\hline Pope Felix & & $\checkmark$ & $\checkmark$ & $\checkmark$ & $\checkmark$ & $\checkmark$ & & \\
\hline Felix and Audactus & & $\checkmark$ & $\checkmark$ & & $\checkmark$ & $\checkmark$ & $\checkmark$ & \\
\hline Felix and Cucusate & & $\checkmark$ & $\checkmark$ & & & & $\checkmark$ & \\
\hline Felix and Simplicanus & $\checkmark$ & $\checkmark$ & & & & & & \\
\hline Firmius & & $\checkmark$ & $\checkmark$ & & & & & \\
\hline Flora and Mary & & $\checkmark$ & $\checkmark$ & & & & & \\
\hline Florence the Virgin & & $\checkmark$ & $\checkmark$ & & & & & \\
\hline Florentıus & & $\checkmark$ & $\checkmark$ & & & & & \\
\hline Franc1s of Assisi & $\checkmark$ & $\checkmark$ & $\checkmark$ & & $\checkmark$ & $\checkmark$ & & \\
\hline Francis de Paul & $\checkmark$ & $\checkmark$ & $\checkmark$ & $\checkmark$ & & $\checkmark$ & & \\
\hline Froylanus & & & $\checkmark$ & & & & & \\
\hline Fructase & & $\checkmark$ & $\checkmark$ & & & & $\checkmark$ & \\
\hline $\begin{array}{c}\text { Fructase, Augurius, and } \\
\text { Eulogius }\end{array}$ & & $\checkmark$ & $\checkmark$ & & & & & \\
\hline Frutus of Segov1a & & & $\checkmark$ & & & & & \\
\hline Fulgencius & & $\checkmark$ & $\checkmark$ & & & $\checkmark$ & $\sqrt{ }$ & \\
\hline Gabriel the Archangel & $\checkmark$ & & $\checkmark$ & $\checkmark$ & & $\checkmark$ & & \\
\hline $\begin{array}{l}\text { Gamalıel, Nicodemus, and } \\
\text { Abıbon }\end{array}$ & & $\checkmark$ & & & & $\checkmark$ & & \\
\hline Ganada of Oran & & & $\checkmark$ & & & & & \\
\hline Genovefa & & $\checkmark$ & & & & & $\checkmark$ & \\
\hline George & $\checkmark$ & $\checkmark$ & $\checkmark$ & $\checkmark$ & & $\checkmark$ & & \\
\hline George the Monk & & $\checkmark$ & $\checkmark$ & & & & & \\
\hline Gerald & & $\checkmark$ & $\checkmark$ & & & & $\checkmark$ & \\
\hline Germain of Parıs & & $\checkmark$ & & & & & $\checkmark$ & \\
\hline Germain the Martyr & & $\checkmark$ & & & & & $\checkmark$ & \\
\hline Germain of Augerre & & $\checkmark$ & & & & & $\checkmark$ & \\
\hline Gervase and Protase & $\checkmark$ & $\checkmark$ & $\checkmark$ & $\checkmark$ & & $\checkmark$ & & \\
\hline Gideon & & $\checkmark$ & & & & & & $\checkmark$ \\
\hline Gilles & $\checkmark$ & $\checkmark$ & $\checkmark$ & & $\checkmark$ & $\checkmark$ & & \\
\hline Gines, Writer and Martyr & & & $\checkmark$ & & & $\checkmark$ & $\checkmark$ & \\
\hline Gines the Martyr & & & $\checkmark$ & & & $\checkmark$ & $\checkmark$ & \\
\hline Godoleva & & & & & & & $\checkmark$ & \\
\hline Gonzalez de Amatante & & & $\checkmark$ & & & & & \\
\hline Gordıanus and Epımacus & & $\checkmark$ & $\checkmark$ & $\checkmark$ & & $\checkmark$ & & \\
\hline Gorgonius & & $\checkmark$ & $\checkmark$ & & $\checkmark$ & $\checkmark$ & & \\
\hline Pope Gregory & $\checkmark$ & $\checkmark$ & $\checkmark$ & $\checkmark$ & & $\checkmark$ & & \\
\hline Gregory of Nanzianzus & & $\checkmark$ & $\checkmark$ & $\checkmark$ & & $\checkmark$ & & \\
\hline Gregory of Ostia & & $\checkmark$ & $\checkmark$ & & & & & \\
\hline Gregory Thaumaturgus & & $\checkmark$ & $\checkmark$ & & $\checkmark$ & $\sqrt{ }$ & & \\
\hline Gregory of Tours & & $\checkmark$ & & & & & $\checkmark$ & \\
\hline Gregory of Nyssa & & $\checkmark$ & & & & & $\checkmark$ & \\
\hline Grisogonus & $\checkmark$ & & & & & & & \\
\hline Gudula & & $\checkmark$ & & & & & $\checkmark$ & \\
\hline
\end{tabular}




\begin{tabular}{|c|c|c|c|c|c|c|c|c|}
\hline NAME & $\begin{array}{c}\text { PV } \\
(1556)\end{array}$ & $\begin{array}{c}\text { MR } \\
\text { (1584) }\end{array}$ & $\begin{array}{c}\text { AV } \\
(\mathbf{1 5 8 8})\end{array}$ & $\begin{array}{c}\text { PR } \\
(1599)\end{array}$ & $\begin{array}{c}\text { PR } \\
(1601)\end{array}$ & $\begin{array}{c}\text { PR } \\
(1604)\end{array}$ & $\begin{array}{c}\text { PR } \\
(1609)\end{array}$ & $\begin{array}{c}\text { AV } \\
(1609)\end{array}$ \\
\hline Gumarus & & $\checkmark$ & & & & & $\checkmark$ & \\
\hline Gumesindus & & $\checkmark$ & $\checkmark$ & & & & & \\
\hline Gurla and Ab1ldus & & & & & & & $\checkmark$ & \\
\hline Habencius & & $\checkmark$ & $\checkmark$ & & & & & \\
\hline Habukkuk & & & & & & & & $\checkmark$ \\
\hline Haggal & & & & & & & & $\checkmark$ \\
\hline Hedweg of Andechs & & $\checkmark$ & & & & & $\checkmark$ & \\
\hline Helena, Mother of Constantıne & & $\checkmark$ & $\checkmark$ & & & $\checkmark$ & $\checkmark$ & \\
\hline Helias, Paul, and Isıdore & & & $\checkmark$ & & & & & \\
\hline Helus and Eligius & & & $\checkmark$ & & & & & \\
\hline Hermenegaudius & & $\checkmark$ & $\checkmark$ & & & & & \\
\hline Hermenegld & & $\sqrt{\checkmark}$ & $\checkmark$ & $\checkmark$ & & $\sqrt{ }$ & & \\
\hline Hermes & $\checkmark$ & $\checkmark$ & $\checkmark$ & & $\checkmark$ & $\checkmark$ & & \\
\hline Hermogenes and Donatus & & $\checkmark$ & $\checkmark$ & & & & & \\
\hline Hezekıah & & & & & & & & $\checkmark$ \\
\hline Hieremıas & & $\checkmark$ & $\checkmark$ & & & & & \\
\hline Hilary & $\checkmark$ & $\checkmark$ & $\checkmark$ & $\checkmark$ & & $\checkmark$ & & \\
\hline Hilarion & & $\checkmark$ & $\checkmark$ & & $\checkmark$ & $\checkmark$ & & \\
\hline Hippolytus & & $\checkmark$ & $\checkmark$ & & $\checkmark$ & & & \\
\hline Homobonus & & $\checkmark$ & & & & & $\checkmark$ & \\
\hline Honorius, Eutycius, and Stephen & & $\sqrt{ }$ & $\checkmark$ & & & & & \\
\hline Hosea & & & & & & & & $\checkmark$ \\
\hline Hugo & & $\checkmark$ & & & & $\checkmark$ & $\checkmark$ & \\
\hline \multicolumn{9}{|l|}{ Hugon of Granoble } \\
\hline Humbert & & & & & & & $\checkmark$ & \\
\hline Hyacınth, O P. & & $\checkmark$ & & & & & $\checkmark$ & \\
\hline Pope Hygınıus & & $\checkmark$ & $\checkmark$ & $\checkmark$ & & $\checkmark$ & & \\
\hline Ignatius of Antioch & $\checkmark$ & $\checkmark$ & $\sqrt{ }$ & $\checkmark$ & & $\checkmark$ & & \\
\hline Ildephonsus of Toledo & $\checkmark$ & $\checkmark$ & $\checkmark$ & $\checkmark$ & & $\checkmark$ & & \\
\hline $\begin{array}{c}\text { Innumerable Martyrs of } \\
\text { Zaragoza }\end{array}$ & $\checkmark$ & $\checkmark$ & $\checkmark$ & & & & & \\
\hline Pope Innocent & & $\checkmark$ & $\checkmark$ & & $\checkmark$ & $\checkmark$ & & \\
\hline Irene & & $\checkmark$ & $\checkmark$ & & & $\checkmark$ & & \\
\hline Ireneus & & $\checkmark$ & $\checkmark$ & & & $\checkmark$ & $\checkmark$ & \\
\hline Isaac & & & & & & & & $\checkmark$ \\
\hline Isaac the Monk & & $\checkmark$ & $\checkmark$ & & & & & \\
\hline Isacius & & $\checkmark$ & & & & & $\checkmark$ & \\
\hline Isaiah & & & & & & & & $\checkmark$ \\
\hline Isidore of Seville & $\checkmark$ & $\checkmark$ & $\checkmark$ & $\checkmark$ & & $\checkmark$ & & \\
\hline Ivan & & & & & & & $\checkmark$ & \\
\hline Jacob & & $\checkmark$ & & & & & & $\checkmark$ \\
\hline James the Greater & $\checkmark$ & $\checkmark$ & $\checkmark$ & & $\checkmark$ & $\checkmark$ & & \\
\hline James the Lesser & $\checkmark$ & $\checkmark$ & $\checkmark$ & $\checkmark$ & & $\checkmark$ & & \\
\hline James of N1s1ue & & $\checkmark$ & & & & & $\checkmark$ & \\
\hline James the Intercessor & & $\checkmark$ & & & & & $\checkmark$ & \\
\hline James the Hermit & & $\checkmark$ & & & & & $\checkmark$ & \\
\hline Januarıus & & $\sqrt{ }$ & $\checkmark$ & & $\checkmark$ & $\checkmark$ & $\checkmark$ & \\
\hline Jehoshaphat & & & & & & & & $\checkmark$ \\
\hline Jehoshaphat, martyr & & & & & & & $\checkmark$ & \\
\hline Jephthah & & & & & & & & $\checkmark$ \\
\hline Jeremiah & & & & & & & & $\checkmark$ \\
\hline Jerome & $\checkmark$ & $\checkmark$ & $\checkmark$ & & $\checkmark$ & $\checkmark$ & & \\
\hline
\end{tabular}




\begin{tabular}{|c|c|c|c|c|c|c|c|c|}
\hline NAME & $\begin{array}{c}\mathrm{PV} \\
(1556) \\
\end{array}$ & $\begin{array}{c}\mathrm{MR} \\
(1584) \\
\end{array}$ & $\begin{array}{c}\mathrm{AV} \\
(1588)\end{array}$ & $\begin{array}{c}\text { PR } \\
(1599) \\
\end{array}$ & $\begin{array}{c}\text { PR } \\
(1601)\end{array}$ & $\begin{array}{c}\text { PR } \\
(1604)\end{array}$ & $\begin{array}{c}\mathrm{PR} \\
(1609)\end{array}$ & $\begin{array}{c}\mathrm{AV} \\
(\mathbf{1 6 0 9 )}\end{array}$ \\
\hline Job & & $\checkmark$ & & & & & & \\
\hline Joel & & $\checkmark$ & & & & & & \\
\hline Pope John & $\checkmark$ & $\checkmark$ & $\checkmark$ & $\checkmark$ & & $\checkmark$ & & \\
\hline John the Apostle & $\checkmark$ & $\checkmark$ & $\checkmark$ & & $\checkmark$ & $\checkmark$ & & \\
\hline $\begin{array}{l}\text { John the Apostle (before the } \\
\text { Latin Gates) }\end{array}$ & & $\checkmark$ & $\checkmark$ & & & $\checkmark$ & & \\
\hline John the Baptıst (Beheadıng) & $\checkmark$ & $\checkmark$ & $\checkmark$ & & $\checkmark$ & $\checkmark$ & & \\
\hline John the Baptist (Burth) & $\checkmark$ & $\checkmark$ & $\checkmark$ & $\checkmark$ & & $\checkmark$ & & \\
\hline John Calabita & & $\checkmark$ & & & & $\checkmark$ & $\checkmark$ & \\
\hline John Climacus & & $\checkmark$ & $\checkmark$ & & & $\checkmark$ & $\checkmark$ & \\
\hline John Chrysostom & $\checkmark$ & $\checkmark$ & $\checkmark$ & $\checkmark$ & & $\checkmark$ & & \\
\hline John the Damascene & & $\checkmark$ & $\checkmark$ & & & $\checkmark$ & $\checkmark$ & \\
\hline John Eleemosynarius & & $\checkmark$ & $\checkmark$ & & & & & \\
\hline John Gualbert & & $\checkmark$ & & & $\checkmark$ & $\checkmark$ & & \\
\hline John Limosnero & & $\checkmark$ & & & & $\checkmark$ & $\checkmark$ & \\
\hline John and Paul, martyrs & $\checkmark$ & $\checkmark$ & $\checkmark$ & $\checkmark$ & & $\checkmark$ & & \\
\hline Jonah & & $\checkmark$ & & & & & & $\checkmark$ \\
\hline Josiah & & & & & & & & $\checkmark$ \\
\hline Joseph, father of Christ & $\checkmark$ & $\checkmark$ & $\checkmark$ & $\sqrt{ }$ & & $\checkmark$ & & \\
\hline Joseph, son of Rachel & & & & & & & & $\checkmark$ \\
\hline Joshua & & $\checkmark$ & & & & & & $\checkmark$ \\
\hline Juan de Ortega & $\checkmark$ & $\checkmark$ & $\checkmark$ & & & & $\checkmark$ & \\
\hline Judah Maccabee & & & & & & & & $\checkmark$ \\
\hline Judas & & $\checkmark$ & & & & & & $\checkmark$ \\
\hline Judith & & & & & & & & $\checkmark$ \\
\hline Julian of Cuenca & & & $\checkmark$ & & & $\checkmark$ & $\checkmark$ & \\
\hline Julian of Toledo & & $\checkmark$ & $\checkmark$ & $\checkmark$ & & $\checkmark$ & & \\
\hline Julıan and Bastılisa & & $\checkmark$ & $\checkmark$ & & & $\bar{\checkmark}$ & $\checkmark$ & \\
\hline Julıana & & $\checkmark$ & $\checkmark$ & & & & $\checkmark$ & \\
\hline Justa and Rufina & $\checkmark$ & $\checkmark$ & $\checkmark$ & & & & & \\
\hline Justına and Cebrian & $\checkmark$ & $\checkmark$ & $\checkmark$ & & $\checkmark$ & $\checkmark$ & & \\
\hline Justınus & & $\checkmark$ & $\checkmark$ & & & $\checkmark$ & $\checkmark$ & \\
\hline Justus & & $\checkmark$ & $\checkmark$ & & & & & \\
\hline Justus and Pastor & $\checkmark$ & $\checkmark$ & $\checkmark$ & & $\checkmark$ & $\checkmark$ & & \\
\hline Juvenal & & $\checkmark$ & $\checkmark$ & & & & & \\
\hline Lambert & $\checkmark$ & $\checkmark$ & $\checkmark$ & & & & & \\
\hline Laurianus of Seville & & $\checkmark$ & $\checkmark$ & & & & $\checkmark$ & \\
\hline Lawrence & $\checkmark$ & $\checkmark$ & $\checkmark$ & & $\checkmark$ & $\checkmark$ & $\checkmark$ & \\
\hline Lazarus (from Luke 16 19-31) & & & & & & & & $\checkmark$ \\
\hline Lea, nun & & $\checkmark$ & & & & & $\checkmark$ & \\
\hline Leander of Seville & $\checkmark$ & $\checkmark$ & $\checkmark$ & & & $\checkmark$ & $\checkmark$ & \\
\hline Pope Leo & $\checkmark$ & $\checkmark$ & $\checkmark$ & $\checkmark$ & & $\checkmark$ & & \\
\hline Pope Leo II & & $\checkmark$ & $\checkmark$ & $\checkmark$ & & $\checkmark$ & & \\
\hline Leocadia & $\checkmark$ & $\checkmark$ & $\checkmark$ & & $\checkmark$ & $\checkmark$ & & \\
\hline Leonard & $\checkmark$ & $\checkmark$ & $\checkmark$ & & & 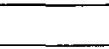 & & \\
\hline Leopold, Marquis of Austra & & $\checkmark$ & & & & & $\checkmark$ & \\
\hline Liberata and her Sisters & & $\checkmark$ & $\checkmark$ & & & & & \\
\hline Licerius & & $\checkmark$ & $\checkmark$ & & & & & \\
\hline Liduvina & & & & & & & $\checkmark$ & \\
\hline Pope Linus & & $\checkmark$ & $\checkmark$ & & $\checkmark$ & $\checkmark$ & & \\
\hline Longinus the Centurion & & $\checkmark$ & $\checkmark$ & & & $\checkmark$ & $\checkmark$ & \\
\hline Lours, bishop of Tolosa & $\checkmark$ & $\checkmark$ & $\checkmark$ & & & & $\checkmark$ & \\
\hline
\end{tabular}




\begin{tabular}{|c|c|c|c|c|c|c|c|c|}
\hline NAME & $\begin{array}{c}\text { PV } \\
(1556) \\
\end{array}$ & $\begin{array}{c}\text { MR } \\
(1584)\end{array}$ & $\begin{array}{c}\mathrm{AV} \\
(\mathbf{1 5 8 8 )}\end{array}$ & $\begin{array}{c}\text { PR } \\
(1599)\end{array}$ & $\begin{array}{c}\text { PR } \\
(1601)\end{array}$ & $\begin{array}{c}\text { PR } \\
(1604)\end{array}$ & $\begin{array}{c}\text { PR } \\
(1609)\end{array}$ & $\begin{array}{c}\mathrm{AV} \\
(1609)\end{array}$ \\
\hline King Louis of France & $\checkmark$ & $\checkmark$ & $\checkmark$ & & $\checkmark$ & $\checkmark$ & & \\
\hline Lot & & & & & & & & $\checkmark$ \\
\hline Pope Lucius & & $\checkmark$ & & & & $\checkmark$ & & \\
\hline Lucrecia & & $\checkmark$ & $\checkmark$ & & & & & \\
\hline Lucy & $\checkmark$ & $\checkmark$ & $\checkmark$ & & $\checkmark$ & $\checkmark$ & & \\
\hline Lucy the Widow & $\checkmark$ & $\checkmark$ & & & & & & \\
\hline Lucy and Germınıanus & & $\checkmark$ & $\checkmark$ & & $\checkmark$ & & & \\
\hline Luke the Evangelist & $\checkmark$ & $\checkmark$ & $\checkmark$ & & $\checkmark$ & $\checkmark$ & & \\
\hline Lupe & & $\checkmark$ & & & & & $\checkmark$ & \\
\hline Lutgardis & & $\checkmark$ & & & & & $\checkmark$ & \\
\hline Macarius of Egypt & & $\checkmark$ & & & & & $\checkmark$ & \\
\hline Macarius of Alexandria & & $\checkmark$ & & & & & $\checkmark$ & \\
\hline Macrina & & $\checkmark$ & & & & & $\checkmark$ & \\
\hline Magınus & & $\checkmark$ & $\checkmark$ & & & & & \\
\hline Malachı & & $\checkmark$ & & & & & & $\checkmark$ \\
\hline Malachı, bishop of Ireland & & $\checkmark$ & & & & & $\checkmark$ & \\
\hline Malchus & & $\checkmark$ & $\checkmark$ & & & $\checkmark$ & $\checkmark$ & \\
\hline Mancius & & $\checkmark$ & $\checkmark$ & & & & & \\
\hline Marcelina & & $\checkmark$ & & & & & $\checkmark$ & \\
\hline Marcelınus & $\checkmark$ & $\checkmark$ & & $\bar{\checkmark}$ & & $\checkmark$ & & \\
\hline Pope Marcelinus & $\checkmark$ & $\checkmark$ & $\checkmark$ & $\checkmark$ & & $\checkmark$ & & \\
\hline Marcellus the Centurion & & $\checkmark$ & $\checkmark$ & & & & $\checkmark$ & \\
\hline Pope Marcellus & & $\checkmark$ & $\checkmark$ & $\checkmark$ & & $\sqrt{ }$ & & \\
\hline Marcellus and Apuleius & & $\checkmark$ & $\checkmark$ & & $\checkmark$ & $\checkmark$ & & \\
\hline Marcus and Marcelianus & & $\checkmark$ & $\checkmark$ & $\checkmark$ & & $\checkmark$ & & \\
\hline Margaret & $\checkmark$ & $\checkmark$ & $\checkmark$ & & & $\checkmark$ & & \\
\hline Margaret of Hungary & & $\checkmark$ & & & & $\checkmark$ & $\checkmark$ & \\
\hline Marına or Margarıta & $\checkmark$ & $\checkmark$ & $\checkmark$ & & & & & \\
\hline Marına & & $\checkmark$ & $\checkmark$ & & & & & \\
\hline $\begin{array}{l}\text { Marius, Martha, Audifax, and } \\
\text { Abachum }\end{array}$ & & $\checkmark$ & & $\checkmark$ & & $\checkmark$ & & \\
\hline Pope Mark & & $\checkmark$ & $\checkmark$ & & $\checkmark$ & $\checkmark$ & & \\
\hline Mark the Evangelist & $\checkmark$ & $\checkmark$ & $\checkmark$ & $\bar{\checkmark}$ & & $\checkmark$ & & \\
\hline Marlus and Other Martyrs & & $\checkmark$ & $\checkmark$ & $\checkmark$ & & & & \\
\hline $\begin{array}{c}\text { Martha, Virgin and Guest of } \\
\text { Christ }\end{array}$ & $\checkmark$ & $\checkmark$ & $\checkmark$ & & $\checkmark$ & $\checkmark$ & & \\
\hline Martha, Virgın and Martyr & & $\checkmark$ & $\checkmark$ & $\checkmark$ & & & & \\
\hline Martıal, bishop & $\checkmark$ & $\checkmark$ & & & & & & \\
\hline Pope Martin & $\checkmark$ & $\checkmark$ & $\checkmark$ & & $\checkmark$ & $\checkmark$ & & \\
\hline Martın of Bracarense & & $\checkmark$ & $\checkmark$ & & & & & \\
\hline Matin of Leon & & $\checkmark$ & $\checkmark$ & & & & & \\
\hline Martin of Tours & $\checkmark$ & $\checkmark$ & $\checkmark$ & & $\checkmark$ & $\checkmark$ & & \\
\hline Martına & $\checkmark$ & $\checkmark$ & & & & & & \\
\hline Martınıanus & & $\checkmark$ & $\checkmark$ & & & $\checkmark$ & $\checkmark$ & \\
\hline Mary Magdalene & $\checkmark$ & $\checkmark$ & $\checkmark$ & & $\checkmark$ & $\checkmark$ & & \\
\hline Mary of Egypt & $\checkmark$ & $\checkmark$ & $\checkmark$ & & & $\checkmark$ & $\checkmark$ & \\
\hline Matrona & & $\checkmark$ & $\checkmark$ & & & & & \\
\hline Matthew the Apostle & $\checkmark$ & $\checkmark$ & $\checkmark$ & & $\checkmark$ & $\checkmark$ & & \\
\hline Matthras the Apostle & $\checkmark$ & $\checkmark$ & $\checkmark$ & $\checkmark$ & & $\checkmark$ & & \\
\hline Maurıce and His Companıons & $\checkmark$ & $\checkmark$ & $\checkmark$ & & $\checkmark$ & $\checkmark$ & & \\
\hline Maurilio of Angiers & & $\checkmark$ & & & & & $\checkmark$ & \\
\hline Mauro, abbot & $\checkmark$ & $\checkmark$ & $\checkmark$ & $\checkmark$ & & $\checkmark$ & & \\
\hline
\end{tabular}




\begin{tabular}{|c|c|c|c|c|c|c|c|c|}
\hline NAME & $\begin{array}{c}\text { PV } \\
(1556)\end{array}$ & $\begin{array}{c}\text { MR } \\
(\mathbf{1 5 8 4}) \\
\end{array}$ & $\begin{array}{c}\text { AV } \\
(1588)\end{array}$ & $\begin{array}{c}\text { PR } \\
(1599)\end{array}$ & $\begin{array}{c}\text { PR } \\
(1601)\end{array}$ & $\begin{array}{c}\text { PR } \\
(1604)\end{array}$ & $\begin{array}{c}\text { PR } \\
(1609)\end{array}$ & $\begin{array}{c}A V \\
(1609)\end{array}$ \\
\hline Maxelende & & & & & & & $\checkmark$ & \\
\hline Melanıa & & $\checkmark$ & & & & & $\checkmark$ & \\
\hline Melchızedek & & & & & & & & $\checkmark$ \\
\hline Menas & $\checkmark$ & & $\checkmark$ & & $\checkmark$ & $\checkmark$ & & \\
\hline Micah & & & & & & & & $\sqrt{2}$ \\
\hline Michael & & $\checkmark$ & $\checkmark$ & $\checkmark$ & & & & \\
\hline Millan & & & & & & & $\checkmark$ & \\
\hline Pope Miltiades & & $\checkmark$ & $\checkmark$ & & $\checkmark$ & $\checkmark$ & & \\
\hline Monica & & $\checkmark$ & $\checkmark$ & $\checkmark$ & & $\checkmark$ & & \\
\hline Moses & & $\checkmark$ & & & & & & $\checkmark$ \\
\hline Moses, hermit and bishop & & $\checkmark$ & & & & & $\checkmark$ & \\
\hline Moses, hermit & & $\checkmark$ & & & & & $\checkmark$ & \\
\hline Nabor and Felix & $\checkmark$ & $\checkmark$ & $\checkmark$ & $\checkmark$ & $\checkmark$ & $\checkmark$ & & \\
\hline Nahum & & $\checkmark$ & & & & & & $\checkmark$ \\
\hline Narciscus & & $\checkmark$ & $\checkmark$ & & & & $\checkmark$ & \\
\hline Nazaruus and Celsus & $\checkmark$ & $\checkmark$ & $\checkmark$ & $\checkmark$ & $\checkmark$ & $\checkmark$ & & \\
\hline Nereus and Archileus & $\checkmark$ & $\checkmark$ & $\checkmark$ & $\checkmark$ & & $\checkmark$ & & \\
\hline Nicasius & & $\checkmark$ & $\checkmark$ & & & & & \\
\hline Nicephorus & & $\checkmark$ & & & & $\checkmark$ & $\checkmark$ & \\
\hline Nicholas & $\checkmark$ & $\checkmark$ & $\checkmark$ & & $\checkmark$ & $\checkmark$ & & \\
\hline Nicholas of Tolentino & & $\checkmark$ & & & $\checkmark$ & $\checkmark$ & & \\
\hline Nicomedes & & $\checkmark$ & $\checkmark$ & & $\checkmark$ & $\checkmark$ & & \\
\hline Noah & & & & & & & & $\checkmark$ \\
\hline Norbert & & $\checkmark$ & & & & & $\checkmark$ & \\
\hline Nunillo and Alodıa & & $\checkmark$ & $\checkmark$ & & & & - & \\
\hline Obadiah & & & & & & & & $\checkmark$ \\
\hline Odilon & & $\checkmark$ & & & & & $\checkmark$ & \\
\hline Odon & & $\checkmark$ & $\checkmark$ & & & $\checkmark$ & & \\
\hline Olalla & $\checkmark$ & 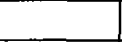 & & & & 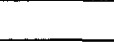 & & \\
\hline Onias & & & & & & & & $\checkmark$ \\
\hline Onuphrius & $\checkmark$ & $\checkmark$ & $\checkmark$ & & & $\checkmark$ & $\checkmark$ & \\
\hline Orencius and Paciencia & & $\checkmark$ & $\checkmark$ & & & & & \\
\hline Oseta & & & & & & & $\checkmark$ & \\
\hline Pacianus & & $\checkmark$ & $\checkmark$ & & & & & \\
\hline Paconius & & $\checkmark$ & & & & & $\checkmark$ & \\
\hline Pancras & $\checkmark$ & $\checkmark$ & $\checkmark$ & $\checkmark$ & & $\checkmark$ & & \\
\hline Pantaleon & $\checkmark$ & $\checkmark$ & $\checkmark$ & & $\checkmark$ & $\checkmark$ & & \\
\hline Patrick & & $\checkmark$ & $\checkmark$ & & & & & \\
\hline Paul the Apostle & $\checkmark$ & $\checkmark$ & $\checkmark$ & $\checkmark$ & & $\checkmark$ & & \\
\hline Paul the Apostle (Conversion) & $\checkmark$ & $\checkmark$ & $\checkmark$ & $\checkmark$ & & $\checkmark$ & & \\
\hline Paul the Hermit & $\checkmark$ & $\checkmark$ & $\checkmark$ & $\checkmark$ & & $\checkmark$ & & \\
\hline Paula, w1dow & $\checkmark$ & $\checkmark$ & $\checkmark$ & & & $\checkmark$ & $\checkmark$ & \\
\hline Paulinus, bishop & $\checkmark$ & $\checkmark$ & $\checkmark$ & $\checkmark$ & & $\checkmark$ & & \\
\hline Pelagıa & & $\checkmark$ & $\checkmark$ & & & $\checkmark$ & $\checkmark$ & \\
\hline Pelagius & & $\checkmark$ & $\checkmark$ & & & & $\checkmark$ & \\
\hline Perpetua and Felicity & & $\checkmark$ & $\checkmark$ & $\checkmark$ & $\checkmark$ & $\checkmark$ & & \\
\hline Pope Peter of Alexandria & $\checkmark$ & $\checkmark$ & $\checkmark$ & & $\checkmark$ & $\checkmark$ & & \\
\hline Peter the Apostle & $\checkmark$ & $\checkmark$ & $\checkmark$ & $\checkmark$ & $\checkmark$ & $\checkmark$ & & \\
\hline Peter the Apostle (In Chains) & $\checkmark$ & $\checkmark$ & $\checkmark$ & & & $\checkmark$ & & \\
\hline Peter the Apostle (Imprisoned) & $\checkmark$ & $\checkmark$ & & & & & & \\
\hline Peter Bracarense & & $\checkmark$ & $\checkmark$ & & & & & \\
\hline
\end{tabular}




\begin{tabular}{|c|c|c|c|c|c|c|c|c|}
\hline NAME & $\begin{array}{c}\text { PV } \\
(1556)\end{array}$ & $\begin{array}{c}\text { MR } \\
\text { (1584) }\end{array}$ & $\begin{array}{c}\text { AV } \\
(1588)\end{array}$ & $\begin{array}{c}\text { PR } \\
(1599)\end{array}$ & $\begin{array}{c}\text { PR } \\
(1601)\end{array}$ & $\begin{array}{c}\text { PR } \\
(1604)\end{array}$ & $\begin{array}{c}\text { PR } \\
(1609)\end{array}$ & $\begin{array}{c}A V \\
(1609)\end{array}$ \\
\hline Peter Celestine & & $\checkmark$ & & & & & $\checkmark$ & \\
\hline Peter Crisolous & & $\checkmark$ & & & & & $\checkmark$ & \\
\hline Peter Gonzalez Telmo & & $\checkmark$ & $\checkmark$ & & & $\checkmark$ & $\checkmark$ & \\
\hline Peter of Osma & & $\checkmark$ & $\checkmark$ & & & & & \\
\hline Peter of Seville & & $\checkmark$ & $\checkmark$ & & & & & \\
\hline Peter Ubalabomso & & $\checkmark$ & $\checkmark$ & & & & & \\
\hline Peter of Verona & $\checkmark$ & $\checkmark$ & $\checkmark$ & $\checkmark$ & & $\checkmark$ & & \\
\hline Peter and Marcelınus & $\checkmark$ & $\checkmark$ & $\checkmark$ & $\checkmark$ & & & & \\
\hline Petronula & $\checkmark$ & $\checkmark$ & $\checkmark$ & $\checkmark$ & & $\checkmark$ & & \\
\hline Petronius & & $\checkmark$ & & & & & $\checkmark$ & \\
\hline Philıp & $\checkmark$ & $\checkmark$ & $\checkmark$ & $\checkmark$ & & $\checkmark$ & & \\
\hline Pope Pius & & $\checkmark$ & $\checkmark$ & & $\checkmark$ & $\checkmark$ & & \\
\hline Placidus & & $\checkmark$ & & & $\checkmark$ & $\checkmark$ & & \\
\hline Polycarp & & $\checkmark$ & $\checkmark$ & $\checkmark$ & & $\checkmark$ & & \\
\hline Pomposa & & $\checkmark$ & $\checkmark$ & & & & & \\
\hline Pope Poncianus & & $\checkmark$ & $\checkmark$ & & $\checkmark$ & $\checkmark$ & & \\
\hline Poncus & & $\checkmark$ & $\checkmark$ & & & & & \\
\hline Potenciana & & & $\checkmark$ & $\checkmark$ & & $\checkmark$ & & \\
\hline Praxedes & & $\checkmark$ & $\checkmark$ & & $\checkmark$ & $\checkmark$ & & \\
\hline Prefectus & & & $\checkmark$ & & & & & \\
\hline Primus and Felıcian & $\checkmark$ & $\checkmark$ & $\checkmark$ & $\checkmark$ & & $\checkmark$ & & \\
\hline Prisca & & $\checkmark$ & $\checkmark$ & $\checkmark$ & & $\checkmark$ & & \\
\hline Primitivus & & $\checkmark$ & & & & & $\checkmark$ & \\
\hline Processus and Martınıanus & $\checkmark$ & $\checkmark$ & $\checkmark$ & & $\checkmark$ & $\checkmark$ & & \\
\hline Procopius & & $\checkmark$ & -1 & & & - & $\checkmark$ & \\
\hline Prosperus & & $\checkmark$ & $\checkmark$ & & 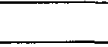 & $\checkmark$ & $\checkmark$ & \\
\hline Protus, Hyacinth and Eugenıa & $\checkmark$ & $\checkmark$ & $\checkmark$ & & $\checkmark$ & $\checkmark$ & & \\
\hline Prudence & & $\checkmark$ & $\checkmark$ & & & & & \\
\hline Quinterıa & $\checkmark$ & $\checkmark$ & $\checkmark$ & & & & & \\
\hline Raymond of Peñaforte & & & $\checkmark$ & & & & $\checkmark$ & \\
\hline Rem1 & $\checkmark$ & $\checkmark$ & $\checkmark$ & & $\checkmark$ & $\checkmark$ & & \\
\hline Robert & & $\checkmark$ & $\checkmark$ & & & & & \\
\hline Roche & $\checkmark$ & $\checkmark$ & $\checkmark$ & & & $\checkmark$ & $\checkmark$ & \\
\hline Rodesindo & & & $\checkmark$ & & & & & \\
\hline Romanus Ostiarıus & & $\checkmark$ & $\checkmark$ & & $\checkmark$ & $\checkmark$ & & \\
\hline Roman the Monk & & $\checkmark$ & $\checkmark$ & & & & & \\
\hline Romuald & & $\checkmark$ & & $\checkmark$ & & $\checkmark$ & & \\
\hline Ruderico & & $\checkmark$ & $\checkmark$ & & & & & \\
\hline Rufina and Secunda & $\checkmark$ & $\checkmark$ & $\checkmark$ & & $\checkmark$ & $\checkmark$ & & \\
\hline Sabbas the Abbot & $\checkmark$ & $\checkmark$ & $\checkmark$ & & $\checkmark$ & $\checkmark$ & & \\
\hline Sabina & $\checkmark$ & $\checkmark$ & $\checkmark$ & & $\checkmark$ & $\checkmark$ & $\checkmark$ & \\
\hline Salomon & & & $\checkmark$ & & & & & \\
\hline Samson & & & & & & & & $\checkmark$ \\
\hline Samuel & & $\checkmark$ & & & & & & $\checkmark$ \\
\hline Sancho & & $\checkmark$ & $\checkmark$ & & & & & \\
\hline Sandalıus & & $\checkmark$ & $\checkmark$ & & & & & \\
\hline Saturninus and Sisinius & & $\checkmark$ & $\checkmark$ & & $\checkmark$ & $\checkmark$ & & \\
\hline Saturnınus and Honestus & & $\checkmark$ & $\checkmark$ & & & & & \\
\hline Sebastian & $\checkmark$ & $\checkmark$ & $\checkmark$ & $\checkmark$ & & & & \\
\hline Secundinus & & $\checkmark$ & $\checkmark$ & & & & & \\
\hline Sergius and Bacchius & $\checkmark$ & $\checkmark$ & $\checkmark$ & & $\checkmark$ & $\checkmark$ & & \\
\hline Servandus and Germain & $\checkmark$ & $\checkmark$ & $\checkmark$ & & & & $\checkmark$ & \\
\hline
\end{tabular}




\begin{tabular}{|c|c|c|c|c|c|c|c|c|}
\hline NAME & $\begin{array}{c}\text { PV } \\
(1556)\end{array}$ & $\begin{array}{c}\text { MR } \\
(\mathbf{1 5 8 4 )}\end{array}$ & $\begin{array}{c}\text { AV } \\
(\mathbf{1 5 8 8})\end{array}$ & $\begin{array}{c}\text { PR } \\
(1599)\end{array}$ & $\begin{array}{c}\text { PR } \\
(1601)\end{array}$ & $\begin{array}{c}\mathrm{PR} \\
(\mathbf{1 6 0 4 )}\end{array}$ & $\begin{array}{c}\text { PR } \\
(1609)\end{array}$ & $\begin{array}{c}\text { AV } \\
(1609)\end{array}$ \\
\hline Servant of God, a monk & & & $\checkmark$ & & & & & \\
\hline Servulus & & & & & & & $\checkmark$ & \\
\hline Severın & & $\checkmark$ & $\checkmark$ & & & & & \\
\hline Sidonius & & & & & & & $\checkmark$ & \\
\hline Simeon & & $\checkmark$ & $\checkmark$ & $\checkmark$ & & & & \\
\hline Simeon Metaphrastes & & $\checkmark$ & $\checkmark$ & & & $\checkmark$ & & \\
\hline Simeon Stylites & & $\checkmark$ & $\checkmark$ & & & $\checkmark$ & $\checkmark$ & \\
\hline Simon and Judas, Apostles & $\checkmark$ & $\checkmark$ & $\checkmark$ & & $\checkmark$ & $\checkmark$ & & \\
\hline $\begin{array}{c}\text { Simplicanus, Faustus, and } \\
\text { Beatrice }\end{array}$ & & $\checkmark$ & $\checkmark$ & & $\checkmark$ & $\checkmark$ & $\checkmark$ & \\
\hline Sinforosa and Her Seven Sons & & $\checkmark$ & $\checkmark$ & & $\checkmark$ & $\checkmark$ & & \\
\hline Pope Sixtus II & $\checkmark$ & $\checkmark$ & $\checkmark$ & & $\checkmark$ & $\checkmark$ & & \\
\hline King Solomon & & & & & & & & $\checkmark$ \\
\hline Pope Soter & & $\checkmark$ & $\checkmark$ & $\checkmark$ & & $\checkmark$ & & \\
\hline Stanislaus & & $\checkmark$ & & $\checkmark$ & & $\checkmark$ & & \\
\hline Stephen the Protomartyr & $\checkmark$ & $\checkmark$ & $\checkmark$ & & $\checkmark$ & $\checkmark$ & & \\
\hline Pope Stephen & & $\checkmark$ & $\checkmark$ & & $\checkmark$ & & & \\
\hline King Stephen of Hungary & & $\checkmark$ & & & & & $\checkmark$ & \\
\hline Susanna & & $\checkmark$ & $\checkmark$ & & $\checkmark$ & $\checkmark$ & & \\
\hline Susanna, wife of Joachim & & $\checkmark$ & & & & & & $\checkmark$ \\
\hline Pope Sylverius & & $\checkmark$ & $\checkmark$ & & $\checkmark$ & & & \\
\hline Pope Sylvester & $\checkmark$ & $\checkmark$ & $\checkmark$ & $\checkmark$ & & $\checkmark$ & & \\
\hline Symphorianus & & $\checkmark$ & $\checkmark$ & & $\checkmark$ & & & \\
\hline Pope Telesphorus & & $\checkmark$ & & & & $\checkmark$ & & \\
\hline Thecla & & & $\checkmark$ & & $\checkmark$ & $\checkmark$ & & \\
\hline Theloy & & & $\checkmark$ & & & & & \\
\hline Theodemiro, monk and martyr & & $\checkmark$ & $\checkmark$ & & & & & \\
\hline Theodora of Alexandria & & $\checkmark$ & $\checkmark$ & & & $\checkmark$ & $\checkmark$ & \\
\hline Theodora, virgin and martyr & & $\checkmark$ & $\checkmark$ & & & $\checkmark$ & $\checkmark$ & \\
\hline Theodore & $\checkmark$ & $\checkmark$ & $\checkmark$ & & $\checkmark$ & $\checkmark$ & $\checkmark$ & \\
\hline Theodosius & & $\checkmark$ & & & & & $\checkmark$ & \\
\hline Theotonius & & & $\checkmark$ & & & & & \\
\hline Theodulus & & & & $\checkmark$ & & & & \\
\hline Thomas the Apostle & $\checkmark$ & $\checkmark$ & $\checkmark$ & & $\checkmark$ & $\checkmark$ & & \\
\hline Thomas Aquinas & $\checkmark$ & $\checkmark$ & $\checkmark$ & $\checkmark$ & & $\checkmark$ & & \\
\hline Thomas a Beckett & & $\checkmark$ & $\checkmark$ & & $\checkmark$ & $\checkmark$ & & \\
\hline Timothy & & $\checkmark$ & $\checkmark$ & $\checkmark$ & & & & \\
\hline Timothy and Sinforianus & $\checkmark$ & & $\checkmark$ & & $\checkmark$ & $\checkmark$ & & \\
\hline Tirburcius the Martyr & $\checkmark$ & & $\checkmark$ & $\checkmark$ & $\checkmark$ & $\checkmark$ & & \\
\hline $\begin{array}{c}\text { Tirburcius, Valerianus, and } \\
\text { Maximus }\end{array}$ & & & $\checkmark$ & $\checkmark$ & & & & \\
\hline Tobias & & $\checkmark$ & & & & & & $\checkmark$ \\
\hline $\begin{array}{l}\text { Torcatus and other saintly } \\
\text { bishops and confessors }\end{array}$ & & $\checkmark$ & $\checkmark$ & & & & $\checkmark$ & \\
\hline Toribıus, Bishop & $\checkmark$ & & $\checkmark$ & & & & $\checkmark$ & \\
\hline Trifon, Respicius, and Ninfa & & & $\checkmark$ & & $\checkmark$ & $\checkmark$ & & \\
\hline Udalrico of Augusta & & & & & & & $\checkmark$ & \\
\hline Pope Urban & $\checkmark$ & $\checkmark$ & $\checkmark$ & $\checkmark$ & & $\checkmark$ & & \\
\hline $\begin{array}{l}\text { Ursula with the Eleven } \\
\text { Thousand Virgins }\end{array}$ & $\checkmark$ & $\checkmark$ & $\checkmark$ & & $\checkmark$ & $\checkmark$ & & \\
\hline Valentıne & $\checkmark$ & $\checkmark$ & $\checkmark$ & $\checkmark$ & & $\checkmark$ & & \\
\hline
\end{tabular}




\begin{tabular}{|c|c|c|c|c|c|c|c|c|}
\hline NAME & $\begin{array}{c}\text { PV } \\
(1556)\end{array}$ & $\begin{array}{c}\text { MR } \\
(\mathbf{1 5 8 4 )}\end{array}$ & $\begin{array}{c}\text { AV } \\
(1588)\end{array}$ & $\begin{array}{c}\text { PR } \\
(1599)\end{array}$ & $\begin{array}{c}\text { PR } \\
(1601) \\
\end{array}$ & $\begin{array}{c}\text { PR } \\
(1604)\end{array}$ & $\begin{array}{c}\text { PR } \\
(1609)\end{array}$ & $\begin{array}{c}\text { AV } \\
(1609)\end{array}$ \\
\hline $\begin{array}{c}\text { Valerian, Tiburcius, and } \\
\text { Maximus } \\
\end{array}$ & & $\checkmark$ & & $\checkmark$ & & $\checkmark$ & & \\
\hline Valerius of Seville & $\checkmark$ & $\checkmark$ & $\checkmark$ & & & & & \\
\hline Venilde & & & $\checkmark$ & & & & & \\
\hline Verıssımus, Maxıma, and Julıa & & $\checkmark$ & $\checkmark$ & & & & & \\
\hline Pope Victor & & $\checkmark$ & $\checkmark$ & & $\checkmark$ & $\checkmark$ & & \\
\hline Victor of Biacarense & & $\checkmark$ & $\checkmark$ & & & & & \\
\hline $\begin{array}{l}\text { Victor, Stercatus, and } \\
\text { Antınogenes }\end{array}$ & & $\checkmark$ & $\checkmark$ & & & & & \\
\hline Victoria of Benamarin & & $\checkmark$ & $\checkmark$ & & & & $\checkmark$ & \\
\hline Victorinus the Abbot & & $\checkmark$ & $\checkmark$ & & & & & \\
\hline Vincent of Colibre & & $\checkmark$ & $\checkmark$ & & & & & \\
\hline Vincent Ferrer & $\checkmark$ & $\checkmark$ & $\checkmark$ & & & $\checkmark$ & & \\
\hline Vincent of Leon & & $\checkmark$ & $\checkmark$ & & & & & \\
\hline Vincent the Martyr & $\checkmark$ & $\checkmark$ & $\checkmark$ & $\checkmark$ & & $\checkmark$ & & \\
\hline Vincent, Sabına, and Cristeta & $\checkmark$ & $\checkmark$ & $\checkmark$ & & & $\checkmark$ & $\checkmark$ & \\
\hline Vitalis & $\checkmark$ & $\checkmark$ & $\checkmark$ & $\checkmark$ & & $\checkmark$ & & \\
\hline Vitalis and Agricola & $\checkmark$ & $\checkmark$ & $\checkmark$ & & $\checkmark$ & $\checkmark$ & & \\
\hline Vitus, Modestus, and Crecencia & $\checkmark$ & $\checkmark$ & $\checkmark$ & $\checkmark$ & & $\checkmark$ & & \\
\hline Walburga & & $\checkmark$ & & & & & $\checkmark$ & \\
\hline Wenceslaus I of Bohemia & & $\checkmark$ & & & & & $\checkmark$ & \\
\hline William of Aquitaine & & & & & & & $\checkmark$ & \\
\hline Wistremundus & & $\checkmark$ & $\checkmark$ & & & & & \\
\hline Zecharıah & & $\checkmark$ & & & & & & $\checkmark$ \\
\hline $\begin{array}{l}\text { Zechariah, father of John the } \\
\text { Baptist }\end{array}$ & & $\checkmark$ & & & & & & \\
\hline Zechariah Ben Jehoiada & & & & & & & & $\checkmark$ \\
\hline Zenobius of Florence & & $\checkmark$ & & & & & $\checkmark$ & \\
\hline Zephariah & & & & & & & & $\checkmark$ \\
\hline Pope Zephermus & & $\checkmark$ & $\checkmark$ & & $\checkmark$ & $\checkmark$ & & \\
\hline Zerubbabel, Ezra, and Nehemiah & & & & & & & & $\checkmark$ \\
\hline Zoylo & & $\checkmark$ & $\checkmark$ & & & & & \\
\hline Francis Borgia & & & & & & & $\checkmark$ & \\
\hline Francis Xavier & & & & & & & $\checkmark$ & \\
\hline Ignatius of Loyola & & & & & $\checkmark$ & $\checkmark$ & $\checkmark$ & \\
\hline Luss de Gonzaga & & & & & & & $\checkmark$ & \\
\hline Stanıslaus Kostka & & & & & & & $\checkmark$ & \\
\hline
\end{tabular}




\section{APPENDIX 6: THE ANNOTATIONS FROM RIBADENEYRA'S FLOS SANCTORUM}

Texts that appear in bold featured in Laurentius Surius's De probatis sanctorum historiis.

1. Bible..$^{511}$

a. Featured In: Francis, Thomas Aquinas, Peter, Paul, James the Greater, Justus and Pastor, Stephen, John.

2. Chronicle of the Order of Saint Francis. ${ }^{512}$

a. Featured In: Bonaventure.

3. Chronicle of the Minors. ${ }^{513}$

a. Featured In: Francis.

4. Decrees from the Council of Florence. ${ }^{514}$

a. Featured In: Augustine.

5. Decrees from the Eighth Council of Toledo. ${ }^{515}$

a. Featured In: Augustine.

6. Decrees from the Third Council of Carthage. ${ }^{516}$

a. Featured In: Augustine.

7. Micrologus de ecclesiasticis observationibus. ${ }^{517}$

a. Featured In: Paul.

8. Roman Martyrology. ${ }^{518}$

a. Featured In: Thomas Aquinas, Bonaventure, Paul, Justus and Pastor.

9. Synodical Letter by the Council of Epheseus to the Clerics of Constantinople. ${ }^{519}$

a. Featured In: John.

10. Ado of Vienna. Chronicle. ${ }^{520}$

a. Featured In: Augustine, Paul, Justus and Pastor, Sebastian.

11. Ambrose of Milan. Commentaries. ${ }^{521}$

a. Featured In: Paul.

12. Ambrose of Milan. Explanation of the Psalms. ${ }^{522}$

a. Featured In: John.

13. Ambrose of Milan. On the Offices of Ministers. ${ }^{523}$

a. Featured In: Augustine.

14. Ambrose of Milan: On Faith. ${ }^{524}$

${ }^{511}$ Flos (1599), 369, 380, 678-82, 685-86, 691-92, 694-96, 698-706, 708; Flos (1601), 66-67, 69, $71,150,258,264-65,268,414-15,424,435,739,743-44,746-50,752-54,759,765-67$.

${ }^{512}$ Flos (1601), 31 .

${ }^{513}$ Flos (1601), 410-11, 413, 415-17, 419-20, 434, 436-37.

${ }^{514}$ Flos (1601), 277.

${ }^{515}$ Flos (1601), 277.

${ }^{516}$ Flos (1601), 269.

${ }^{517}$ Flos (1599), 694.

${ }^{518}$ Flos (1599), 383, 705, 707; Flos (1601), 31, 151.

${ }^{519}$ Flos (1601), 754 .

${ }^{520}$ Flos (1599), 225, 705; Flos (1601), 151, 284.

${ }^{521}$ Flos $(1599), 699$.

${ }^{522}$ Flos (1601), 765 .

${ }^{523}$ Flos (1601), 279.

${ }^{524}$ Flos (1601), 748, 759. 
a Featured In John

15 Ambrose of Milan On Repentence ${ }^{525}$

a Featured In Stephen

16 Ambrose of Milan Sermons 526

a Featured In Augustine, Peter, Sebastian, John

17 Anastasius Quaestiones in scriptura 527

a Featured In Peter

18 Anselm Commentarles ${ }^{528}$

a Featured In Paul

19 Athanasius Letters ${ }^{529}$

a Featured In Paul

20 Antonıno de Pierozzi O P Chronicle 530

a Featured In Domınıc, Francis, Thomas Aquinas, Bonaventure, Augustine, Justus and Pastor

21 Arator De actıbus Apostolorum ${ }^{531}$

a Featured In Peter

22 Arnobius of Sicca Adversus Nationes ${ }^{532}$

a Featured In Peter

23 Atticus Letters ${ }^{533}$

a Featured In Peter

24 Augustine Against Julian 534

a Featured In Augustine

25 Augustine Answer to the Letters of Petllian, Btshop of Cirta ${ }^{535}$

a Featured In Augustine

26 Augustıne Brief Collations on the Third Day ${ }^{536}$

a Featured In Augustine

27 Augustine City of God ${ }^{537}$

a Featured In Peter, Stephen, John

28 Augustine Commentary on John ${ }^{538}$

a Featured In John

29 Augustine Confessions 539

a Featured In Augustine, Paul, John

${ }^{525}$ Flos (1601), 744

${ }^{526}$ Flos (1599), 225, 688, 707, Flos (1601), 284, 763

${ }^{527}$ Flos (1599), 686

${ }^{528}$ Flos (1599), 697

${ }^{529}$ Flos (1599), 705

${ }^{530}$ Flos (1599), 383, Flos (1601), 31, 134, 151, 279, 421

${ }^{531}$ Flos (1599), 681

${ }^{532}$ Flos (1599), 687

${ }^{533}$ Flos (1599), 692

${ }^{534}$ Flos (1601), 278

${ }^{535}$ Flos (1601), 267

${ }^{536}$ Flos (1601), 269 I am unsure whether this work, concerning Genesis, 1s the one against the Manıcheans or the unfinished literal interpretation of Genesis

${ }^{537}$ Flos (1599), 691, Flos (1601), 746, 759

${ }^{538}$ Flos (1601), 757

${ }^{539}$ Flos (1599), 699, Flos (1601), 256-64, 759 
30. Augustine. Expositions on the Psalms. ${ }^{540}$

a. Featured In: Augustine.

31. Augustine. Letters. ${ }^{54}$

a. Featured In: Augustine, Peter, Paul.

32. Augustine. On Christian Doctrine. ${ }^{542}$

a. Featured In: Augustine.

33. Augustine. On the Harmony of the Evangelists. ${ }^{543}$

a. Featured In: Peter, John.

34. Augustine. On the Work of Monks. ${ }^{544}$

a. Featured In: Augustine.

35. Augustine. Questions. ${ }^{545}$

a. Featured In: John.

36. Augustine. Retractions. ${ }^{546}$

a. Featured In: Augustine.

37. Augustine. Proceedings with Emeritus. ${ }^{547}$

a. Featured In: Augustine.

38. Augustine. Sermons. ${ }^{548}$

$$
\text { Augustine. }
$$

a. Featured In: Augustine, Sebastian, Stephen.

39. Augustine. Treatises on the Gospel of John. ${ }^{549}$

a. Featured In: Peter, John.

40. Baronius, Caesar. C.O. Ecclesiastic Annals from Christ's Nativity to $1198 .{ }^{550}$

a. Featured In: Augustine, Peter, Paul, James the Greater, Sebastian, John.

41. Baronius, Caesar. C.O. Life of St. Ambrose. ${ }^{551}$

a. Featured In: Augustine.

42. Baronius, Caesar. C.O. ed. Roman Martyrology. ${ }^{552}$

a. Featured In: Francis, Peter, Paul, James the Greater, Justus and Pastor, Sebastian, Stephen, John.

43. Basil the Great. Sermons. ${ }^{553}$

a. Featured In: John.

44. Bede. Ecclesiastic History of the English People. ${ }^{554}$

a. Featured In: Sebastian.

45. Bede. Commentaries. ${ }^{555}$

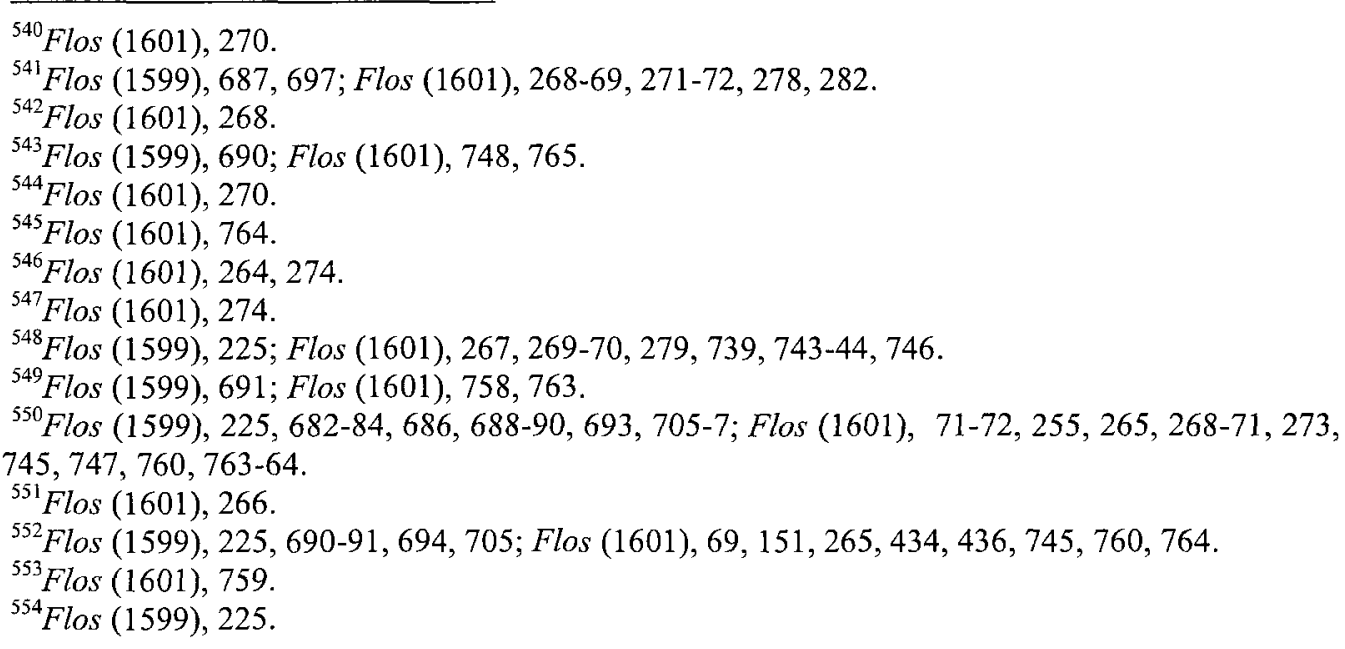


46. Bede. Martyrology. ${ }^{556}$

a. Featured In: Peter, John.

a. Featured In: Paul, Justus and Pastor.

47. Bede. On the Age of the World ${ }^{557}$

a. Featured In: Augustine, John.

48. Bellarmine, Robert. S.J. Controversies. ${ }^{558}$

a. Featured In: Peter.

49. Bernard of Clairvaux. O. Cist. On Consideration. ${ }^{559}$

a. Featured In: Peter.

50. Bernard of Clairvaux. O. Cist. Sermons. ${ }^{560}$

a. Featured In: Augustine.

\section{Bonaventure. O.F.M. Life of St. Francis. ${ }^{561}$}

a. Featured In: Francis.

52. Bonaventure. O.F.M. Soliloquay on the Four Spiritual Exercises. ${ }^{562}$

a. Featured In: Bonaventure.

53. Cassiodorius. Roman Psalter. ${ }^{563}$

a. Featured In: Augustine.

54. Cassius Dio. Roman History. ${ }^{564}$

a. Featured In: Peter.

55. Castillo, Fernando del. O.P. History of the Order of Preachers. ${ }^{565}$

a. Featured In: Dominic, Thomas Aquinas.

56. Catharus, Aretius [=Luther, Martin]. Commentary on 2 Corinthians. ${ }^{566}$

a. Featured In: Paul.

57. Cattani da Diacceto, Francesco the Younger. ${ }^{567}$

a. Featured In: Dominic.

58. Cedrenus, George. Compendium historiarum. ${ }^{568}$

a. Featured In: John.

59. Celestine I. Letters. ${ }^{569}$

a. Featured In: Augustine.

60. Clement I. Apostolic Canons. ${ }^{570}$

a. Featured In: Stephen.

61. Clement of Alexandria. Stromata (Miscellanies). ${ }^{571}$

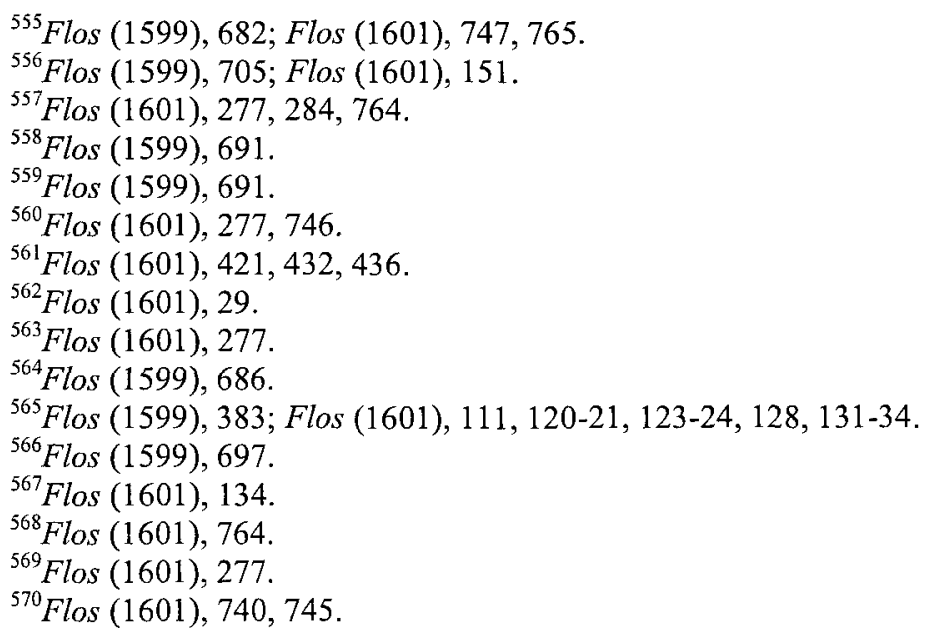


a. Featured In: Peter.

62. Clement V. Constitationes. ${ }^{572}$

a. Featured In: Peter.

63. Clichtove, Josse van. Unknown Work. ${ }^{573}$

a. Featured In: Paul.
64. Cyprian. Letters.

a. Featured In: Peter.

65. Cyril of Alexandria. Against Julian. ${ }^{575}$

a. Featured In: John.

66. Cyril of Jerusalem. Catechism. ${ }^{576}$

a. Featured In: Peter, Paul.

67. Datius of Milan. Chronicle. ${ }^{577}$

a. Featured In: Augustine.

68. Dietrich of Apolda. O.P. Life of St. Dominic. ${ }^{578}$

a. Featured In: Dominic.

69. Dorotheus of Tyre. Synopsis. ${ }^{579}$

a. Featured In: Stephen, John.

70. Durand, Guillaime. Rationale divinorum officiorum. ${ }^{580}$

a. Featured In: Paul.

71. Epiphanius of Salamis. Adversus Haereses. ${ }^{581}$

a. Featured In: Peter, Paul, John.

72. Eusebius of Caesarea. Chronicle. ${ }^{582}$

a. Featured In: Peter, Paul, James the Greater, John.

73. Eusebius of Caesarea. Ecclesiastic History. ${ }^{583}$

a. Featured In: Peter, James the Greater, John.

74. Eusebius of Caesarea. On the Evangelists. ${ }^{584}$

a. Featured In: John.

75. Eusebius of Emesea. Book of Homilies. ${ }^{585}$

a. Featured In: Paul, Stephen.

76. Euthymius Zigabenus. Commentaries. ${ }^{586}$

a. Featured In: John.

77. Flaminio, Marcantonio. Carmina sacra. ${ }^{587}$

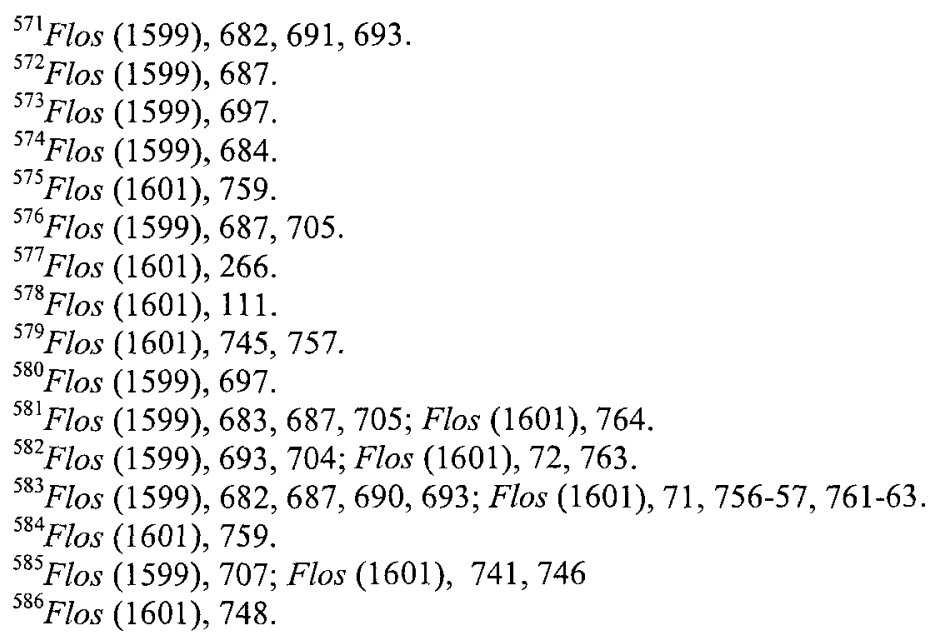


a. Featured In: Dominic.

78. Fulgentius of Ruspe. Sermons. ${ }^{588}$

a. Featured In: Stephen.

79. Garzoni, Giovanni.O.P. Vitae. ${ }^{589}$

a. Featured In: Dominic, Thomas Aquinas.

80. Gaudentius of Bresca. Sermons. ${ }^{500}$

a. Featured In: Paul.

81. Gerson, Jean. De examine doctrinarum. ${ }^{591}$

a. Featured In: Bonaventure.

82. Gratian. Decretum. ${ }^{52}$

a. Featured In: Peter

83. Gregory the Great. Dialogues. ${ }^{593}$

a. Featured In: Sebastian.

84. Gregory the Great. Letters. ${ }^{594}$

a. Featured In: Augustine, Peter.

85. Gregory the Great. Moralityor a Commentary on Job. ${ }^{595}$

a. Featured In: Paul.

86. Gregory Nazianzus. Orations. ${ }^{596}$

a. Featured In: Peter, Paul.

87. Gregory of Nyssa. Life of Gregory Thaumaturgos. ${ }^{597}$

a. Featured In: John.

88. Gregory of Nyssa. On the Inscriptions of the Psalms. ${ }^{598}$

a. Featured In: Peter.

89. Gregory of Nyssa. Sermons. ${ }^{599}$

a. Featured In: Stephen, John.

90. Gregory of Tours. On the Glory of the Martyrs. ${ }^{600}$

a. Featured In: Paul, John.

91. Hilary of Arles. Letters. ${ }^{601}$

a. Featured In: Augustine.

92. Hilary of Poitiers. Commentaries. ${ }^{602}$

a. Featured In: John.

93. Hippolytus of Rome. Book on the Seventy Disciples. ${ }^{603}$

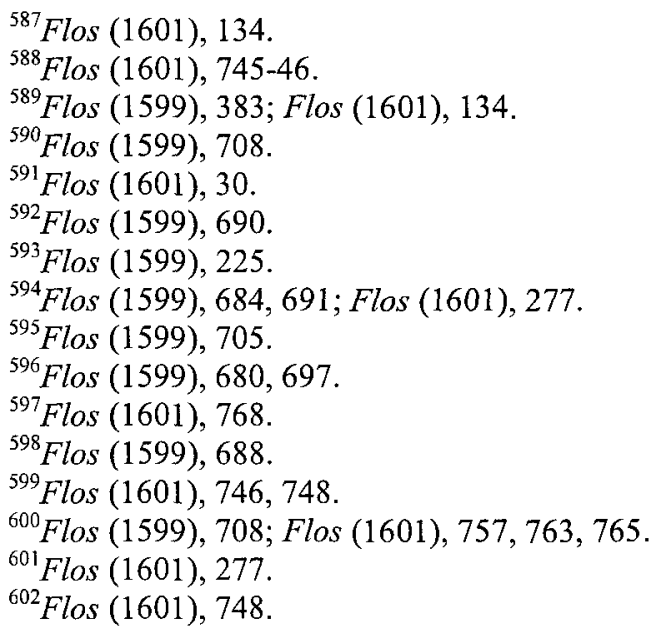


a. Featured In: Paul, Stephen.

94. Hugh of St. Victor. Questions on 2 Corinthians. ${ }^{604}$

a. Featured In: Paul.

95. Hydatius. On the Trinity against the Arians. ${ }^{605}$

a. Featured In: John.

96. Hyginus. Letters. ${ }^{606}$

a. Featured In: John.

97. Ignatius of Antioch. Letters. ${ }^{607}$

a. Featured In: Peter, Stephen.

98. Innocent I. Letters. ${ }^{608}$

a. Featured In: Peter.

99. Irenaeus of Lyons. Adversus Haereses. ${ }^{609}$

a. Featured In: Peter, John.

100. Isidore of Seville. Fathers of the New Testament.$^{610}$

a. Featured In: John.

101. Isidore of Seville. Life of Saint James. ${ }^{611}$

a. Featured In: James the Greater.

102. Isidore of Seville. Mozarabic Breviary. ${ }^{612}$

a. Featured In: Justus and Pastor.

103. Isidore of Seville. Mozarabic Missal. ${ }^{613}$

a. Featured In: Justus and Pastor.

104. Isidore of Seville. On the Lives and Deaths of Saints. ${ }^{614}$

a. Featured In: Paul.

105. Jansen, Cornelius the Elder. Concordia evangelica. ${ }^{615}$

a. Featured In: John.

106. Jerome. Against Jovinianus. ${ }^{616}$

a. Featured In: John.

107. Jerome. Commentaries. ${ }^{617}$

a. Featured In: Paul, John.

108. Jerome. Epitaph to Marcella. ${ }^{618}$

a. Featured In: James the Greater, John.

109. Jerome. Letters. ${ }^{619}$

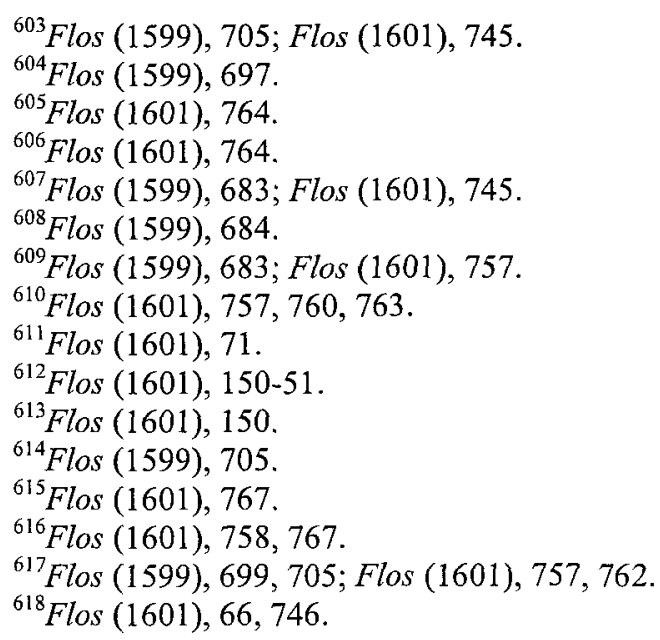


a. Featured In: Augustine, Peter, Paul, John.

110. John Chrysostom. Adhoratio ad Theodorum lapsum. ${ }^{620}$

a. Featured In: John.

111. John Chrysostom. Against Those Who Oppose the Monastic Life. ${ }^{621}$

a. Featured In: Peter.

112. John Chrysostom. Commentaries. ${ }^{622}$

a. Featured In: Paul, John.

113. John Chrysostom. Orations. ${ }^{623}$

a. Featured In: Paul.

114. John Chrysostom. Sermons. ${ }^{624}$

a. Featured In: Peter, Paul, John.

115. John of Damascus. De fide. ${ }^{625}$

a. Featured In: Paul.

116. John the Deacon of Rome. Life of Gregory. ${ }^{626}$

a. Featured In: John.

117. Justinian. Corpus Iuris Civilis. ${ }^{627}$

a. Featured In: Augustine.

118. Justinus. First Apology to Antonius Pius. ${ }^{628}$

a. Featured In: Peter.

119. Leo I. Sermons. ${ }^{629}$

a. Featured In: Paul.

120. Lippomano, Luigi. Sanctorum priscorum patrum vitae. ${ }^{630}$

a. Featured In: John.

121. Luis de León. O.S.A. Guide to Preachers. ${ }^{631}$

a. Featured In: Dominic.

122. Maldonado, Juan. S.J. Commentaries. ${ }^{632}$

a. Featured In: John.

123. Marianus Scotus. Chronicle. ${ }^{633}$

a. Featured In: Augustine.

124. Marulus Spalatensis, Marcus.De institutione bene vivendi per exempla

a. Featured In: Francis.

\footnotetext{
${ }^{619}$ Flos (1599), 684, 697, 704; Flos (1601), 268, 276, 278, 757, 760, 763

${ }^{620}$ Flos (1601), 761 .

${ }^{621}$ Flos (1599), 688.

${ }^{622}$ Flos (1599), 697, 705; Flos (1601), 748, 765.

${ }^{623}$ Flos (1599), 707.

${ }^{624}$ Flos (1599), 680-81, 697, 699, 705, 707; Flos (1601), 749, 759, 763.

${ }^{625}$ Flos (1599), 697.

${ }^{626}$ Flos (1601), 765.

${ }^{627}$ Flos (1601), 270. Especially Book I, Title IV.

${ }^{628}$ Flos (1599), 683.

${ }^{629}$ Flos (1599), 708.

${ }^{630}$ Flos (1601), 757.

${ }^{631}$ Flos (1601), 130.

${ }^{632}$ Flos (1601), 747-48, 759, 763.

${ }^{633}$ Flos (1601), 284.

${ }^{634}$ Flos (1601), 421.
} 
125. Maurolico, Francesco. O.S.B. Martyrology. ${ }^{635}$

a. Featured In: Peter.

126. Maximus of Turin. Sermons. ${ }^{636}$

a. Featured In: Peter.

127. Morales, Ambrosio de. The Life... of the Glorious Boy Martyrs Saints Justus and Pastor. ${ }^{637}$

a. Featured In: Justus and Pastor.

128. Morales, Ambrosio de. General Chronicle of Spain. ${ }^{638}$

a. Featured In: James the Greater, Justus and Pastor.

129. Nicephoros I of Constantinople. Chronography. ${ }^{639}$

a. Featured In: Peter, Stephen, John.

130. Nicephoros Callistus Xanthopulus. Ecclesiastical History. ${ }^{640}$

a. Featured In: Paul.

131. Nicetas the Paphlagonian. Sermons. ${ }^{641}$

a. Featured In: Stephen.

132. Nicholas of Lyra. Commentaries. ${ }^{642}$

a. Featured In: Paul.

133. Origen of Alexandria. Commentaries. ${ }^{643}$

a. Featured In: Peter, Paul.

134. Origen of Alexandria. Sermons. ${ }^{644}$

a. Featured In: John.

135. Paralipus. Question $18 .{ }^{645}$

a. Featured In: Paul.

136. Paul the Deacon. O.S.B. History of the Lombards. ${ }^{646}$

a. Featured In: Augustine, Sebastian.

137. Paulinus of Nola. Letters. ${ }^{647}$

a. Featured In: Augustine, Peter.

138. Paul Orosius. Historyagainst the Pagans. ${ }^{648}$

a. Featured In: Peter.

139. Peter Chrysologus. Sermons. ${ }^{649}$

a. Featured In: Stephen.

140. Peter Damian. O.S.B. Sermons. ${ }^{650}$

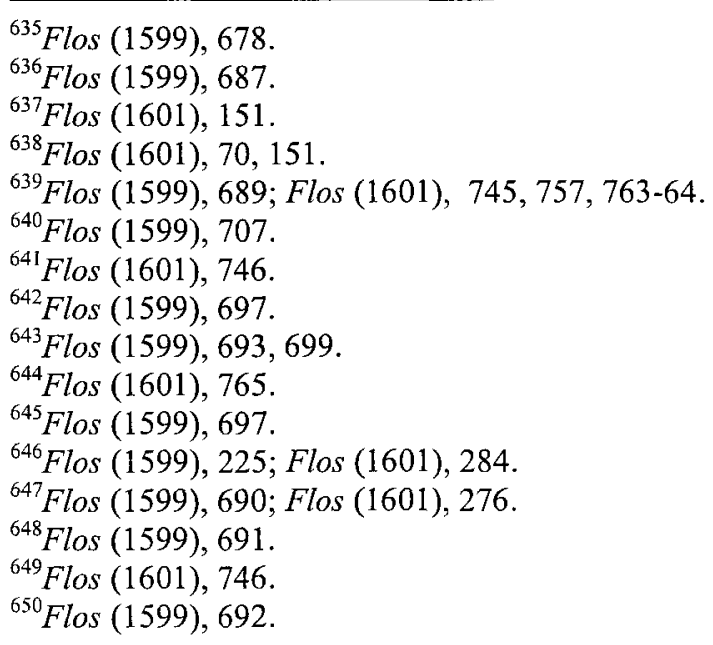


a. Featured In: Peter.

141. Petrus Galesinus. O.F.M. Sancti Bonaventurae vita. ${ }^{651}$

a. Featured In: Bonaventure.

142. Philastrius. Liber de haeresibus. ${ }^{652}$

a. Featured In: Peter.

143. Pius V. Brief on the Celebration of the Feast of These Saints. ${ }^{653}$

a. Featured In: Justus and Pastor.

144. Pizamano, Antonio. O.P. Vita Thome Aquinatisi. ${ }^{654}$

a. Featured In: Thomas Aquinas.

\section{Possidius. Life of Augustine. ${ }^{65}$}

a. Featured In: Augustine.

146. Primasius. Commentaries. ${ }^{656}$

a. Featured In: John.

147. Procopius. De Bello Gothico. ${ }^{657}$

a. Featured In: Peter.

148. Prochorus. On the Life of John. ${ }^{658}$

a. Featured In: John.

149. Prosper of Aquitaine. On the Contemplative Life. ${ }^{659}$

a. Featured In: Augustine.

150. Prosper of Aquitaine. Chronicle. ${ }^{660}$

a. Featured In: Augustine.

151. Prosper of Aquitaine. Letters. ${ }^{661}$

a. Featured In: Augustine.

152. Prudentius. Unknown Work. ${ }^{62}$

a. Featured In: Paul, Justus and Pastor.

153. Pseudo-Augustine..Book of Meditations and Soliloquies and Manual. ${ }^{663}$

a. Featured In: Augustine.

154. Pseudo-Dionysius the Areopagite. On the Letter to John. ${ }^{664}$

a. Featured In: John.

155. Pseudo-Dionysius the Areopagite. On Celestial Hierarchy. ${ }^{665}$

a. Featured In: Paul, John.

156. Pseudo-Dionysius the Areopagite. On the Divine Names. ${ }^{66}$

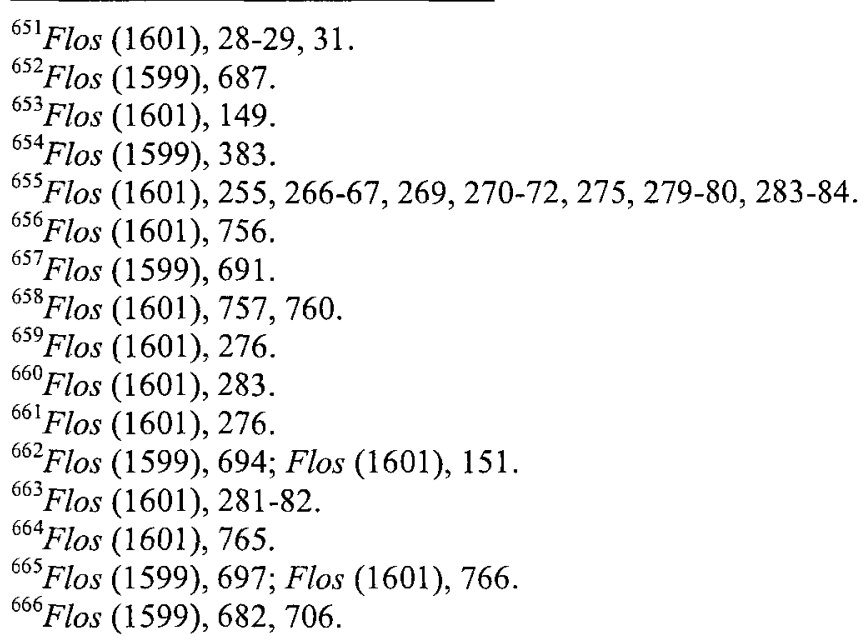


a. Featured In: Peter, Paul.

157. Pseudo-Hegesippus. De exicidio Hierosolymitano. ${ }^{67}$

a. Featured In: Peter.

158. Randulph of Tongres. Bookfor the Observant Canons. ${ }^{668}$

a. Featured In: Augustine.

159. Rupert of Deutz. O.S.B. Commentaries. ${ }^{669}$

a. Featured In: John.

160. Rupert of Deutz. O.S.B. On the Works of the Holy Spirit. ${ }^{670}$

a. Featured In: Augustine.

161. Reggio, Paolo. ${ }^{671}$

a. Featured In: Thomas Aquinas.

162. Romeo, David. ${ }^{672}$

a. Featured In: Thomas Aquinas.

163. Rufinus. Commentarius in symbolum apostolorum. ${ }^{673}$

a. Featured In: Peter.

164. Salmerón, Alfonso. S.J. Commentaries. ${ }^{674}$

a. Featured In: Peter, James the Greater, John.

165. Suetonius. Lives of the Caesars. ${ }^{675}$

a. Featured In: Peter.

166. Severus Sulpicus. Letters. ${ }^{676}$

a. Featured In: Augustine.

167. Simon Metaphrastes. Lives of Saints Peter and Paul. ${ }^{677}$

a. Featured In: Peter, Paul.

168. Simon Metaphrastes. Life of Saint John. ${ }^{678}$

a. Featured In: James the Greater, John.

169. Simon Metaphrastes. Menalogion. ${ }^{679}$

a. Featured In: John.

170. Sixtus IV. O.F.M. Bull for Bonaventure's Canonisation. ${ }^{60}$

a. Featured In: Bonaventure.

171. Sixtus V. O.F.M. Bull. ${ }^{681}$

a. Featured In: Bonaventure.

172. Sixtus of Siena. O.P. Bibliotheca sancta. ${ }^{682}$

${ }^{667}$ Flos (1599), 687-88.

${ }^{668}$ Flos (1601), 266.

${ }^{669}$ Flos (1601), 747.

${ }^{670}$ Flos (1601), 277.

${ }^{671}$ Flos (1599), 383.

${ }^{672}$ Flos (1599), 383.

${ }^{673}$ Flos (1599), 693.

${ }^{674}$ Flos (1599), 682, 690; Flos (1601), 72, 747, 764.

${ }^{675}$ Flos (1599), 686.

${ }^{676}$ Flos (1601), 276.

${ }^{677}$ Flos (1599), 683-84, 688, 699, 705.

${ }^{678}$ Flos (1601), 67, 755, 760, 763 .

${ }^{679}$ Flos (1601), 764. The Menalogion was the ten-volume collection of saints' lives and the source for the lives of Peter, Paul, and John used by Ribadeneyra and Surius.

${ }^{680}$ Flos (1601), 31 .

${ }^{681}$ Flos (1601), 31 . 
a. Featured In: Thomas Aquinas, Augustine, Peter.

173. Sophronius. By Jerusalem. ${ }^{683}$

a. Featured In: Peter.

174. Sophronius. Sermons. ${ }^{684}$

a. Featured In: Paul.

175.Suidas, Lexicon. ${ }^{685}$

a. Featured In: John.

176. Surius, Laurentius. O. Cart. De probatis sanctorum historiis. ${ }^{686}$

a. Featured In: Dominic, Thomas Aquinas, Justus and Pastor.

177. Tacitus. Annals. ${ }^{687}$

a. Featured In: Peter.

178. Tertullian. Against Praxeamus. ${ }^{68}$

a. Featured In: Paul.

179. Tertullian. Apologeticus pro Christianis. ${ }^{69}$

a. Featured In: Peter.

180. Tertullian. On the Soul. ${ }^{690}$

a. Featured In: John

181. Theodore the Interpreter. Commentaries. ${ }^{691}$

a. Featured In: Paul.

182. Theodoret of Cyrus. Religious History. ${ }^{692}$

a. Featured In: John.

183. Theophylact of Ohrid. Commentaries. ${ }^{693}$

a. Featured In: John.

184. Thomas Aquinas. O.P. Commentary on John $21 .{ }^{694}$

a. Featured In: John.

185. Thomas Aquinas. O.P. Summa Theologia. ${ }^{695}$

a. Featured In: Paul, John.

186. Trithemius, Johannes. O.S.B.De scriptoribus ecclesiasticis. ${ }^{696}$

a. Featured In: Bonaventure.

187. Usuard. O.S.B. Martyrology. ${ }^{697}$

a. Featured In: Justus and Pastor, Sebastian, John.

188. Victorinus of Poetovio. Commentaries. ${ }^{698}$

${ }^{682}$ Flos (1599), 383, 693; Flos (1601), 268.

${ }^{683}$ Flos (1599), 693.

${ }^{684}$ Flos (1599), 705.

${ }^{685}$ Flos (1601), 764.

${ }^{686}$ Flos (1599), 383; Flos (1601), 134, 151.

${ }^{687}$ Flos (1599), 686.

${ }^{688}$ Flos (1599), 697.

${ }^{689}$ Flos (1599), 686.

${ }^{690}$ Flos (1601), 763.

${ }^{691}$ Flos (1599), 705.

${ }^{692}$ Flos (1601), 764.

${ }^{693}$ Flos (1601), 757, 763.

${ }^{694}$ Flos (1601), 763.

${ }^{695}$ Flos (1599), 697; Flos (1601), 763.

${ }^{696}$ Flos (1601), 31.

${ }^{697}$ Flos (1599), 225; Flos (1601), 151, 764. 
a. Featured In: John.

${ }^{698}$ Flos (1601), 756. 


\section{APPENDIX 7: THE ANNOTATIONS FROM VILLEGAS'S FLOS SANCTORUM}

1. Bible. ${ }^{699}$

a. Featured In: James the Greater, John, Stephen.

2. Historia de Señora María de Pilar. ${ }^{700}$

a. Featured In: James the Greater.

3. Roman Martyrology. ${ }^{701}$

a. Featured In: Augustine.

4. Ado of Vienna. Chronicle. ${ }^{702}$

a. Featured In: Paul.

5. Ambrose of Milan: On Faith. ${ }^{703}$

a. Featured In: Peter.

6. Ambrose of Milan. Sermons. ${ }^{704}$

a. Featured In: Peter.

7. Antonino de Pierozzi.O.P. Chronicle. ${ }^{705}$

a. Featured In: Dominic, Francis, Augustine.

8. Athanasius, Apologies. ${ }^{706}$

a. Featured In: Peter.

9. Augustine. Against Faustus. ${ }^{707}$

a. Featured In: Paul.

10. Augustine. Against Julian. ${ }^{708}$

a. Featured In: Augustine.

11. Augustine. Confessions. ${ }^{709}$

a. Featured In: Augustine.

12. Basil the Great/Hilary of Poitiers. Refutation against Eunomius/Against the Arians. ${ }^{710}$

a. Featured In: Peter.

13. Basil the Great. Sermons. ${ }^{711}$

a. Featured In: John.

14. Bede. Commentaries. ${ }^{712}$

a. Featured In: John.

15. Bonaventure. O.F.M. Life of St. Francis. ${ }^{713}$

a. Featured In: Francis.

\footnotetext{
${ }^{699}$ Villegas, Flos (1588), 238v, 418r, 420r.

${ }^{700}$ Ibid. 239 r.

${ }^{701}$ Ibid. $300 \mathrm{v}$.

${ }^{702}$ Ibid. 216 r.

${ }^{703}$ Ibid. $210 \mathrm{v}$.

${ }^{704}$ Ibid. 212v, 213r.

${ }^{705}$ Ibid. 260v, 299r, 339v, fol. 342.

${ }^{706}$ Ibid. 213 r.

${ }^{707}$ Ibid. $214 \mathrm{v}$.

${ }^{708}$ Ibid. $299 \mathrm{r}$.

${ }^{709}$ Ibid. 299r, 301r.

${ }^{710}$ Ibid. $213 \mathrm{r}$.

${ }^{711}$ Ibid. $210 \mathrm{v}$.

${ }^{712}$ Ibid. 421r.

${ }^{713}$ Ibid. 339v.
} 
16 Claude D'Espence De Contınentza ${ }^{714}$

a Featured In Peter

17 Clement of Alexandria Stromata (Miscellanies) ${ }^{715}$

a Featured In John

18 Datius of Milan Chronicle 716

a Featured In Augustine

19 Dietrich of Apolda. O.P. Life of St. Dominic. ${ }^{717}$

a Featured In Dominic

20 Dorotheus of Gaza Letters ${ }^{718}$

a Featured In Paul

21 Epıphanıus of Salamıs Adversus Haereses ${ }^{719}$

a Featured In Paul

22 Eusebius of Caesarea. Ecclesiastic History. ${ }^{720}$

a Featured In James the Greater, Stephen, John

23 Garzonı, Giovannı O P Vitae ${ }^{721}$

a Featured In Thomas Aquinas

24 Gregory the Great Moralityor a Commentary on Job ${ }^{722}$

a Featured In Paul

25 Isıdore of Seville Mozarabic Breviary ${ }^{723}$

a Featured In Justus and Pastor

26 Isidore of Seville Mozarabic Missal ${ }^{724}$

a Featured In Justus and Pastor

27 Jerome Against Jovinıanus ${ }^{725}$

a Featured In John

28 Jerome Commentarles ${ }^{726}$

a Featured In John

29 Jerome Epitaph to Marcella ${ }^{727}$

a Featured In James the Greater

30 Jerome Letters ${ }^{728}$

a Featured In John, Paul

31 John Chrysostom Adhoratio ad Theodorum lapsum ${ }^{729}$

a Featured In John

\footnotetext{
${ }^{714}$ Ibid $213 \mathrm{r}$

${ }^{715} \mathrm{Ibid} 422 \mathrm{~V}$

${ }^{716}$ Tbid $300 \mathrm{v}$

${ }^{717}$ Ibid $260 \mathrm{v}$

${ }^{718}$ Ibid $216 \mathrm{r}$

${ }^{719}$ Ibid $216 \mathrm{r}$

${ }^{720}$ Ibld 231v, 419r, 421r, 422r

${ }^{721} \mathrm{Ibld} 127 \mathrm{v}$

${ }^{722} \mathrm{~Tb} 1 \mathrm{~d} 216 \mathrm{r}$

${ }^{723} \mathrm{Ibid} 212 \mathrm{~V}$

${ }^{724} \mathrm{Ibid} 212 \mathrm{v}$

${ }^{725}$ Ibld $421 \mathrm{v}$

${ }^{726}$ Tbid fol 421

${ }^{727}$ Ibld $238 \mathrm{v}$

${ }^{728}$ Ibld 214v, 421r

${ }^{729} \mathrm{Ib}$ Id $422 \mathrm{v}$
} 
32. John Chrysostom. Against Those Who Oppose the Monastic Life. ${ }^{730}$

a. Featured In: Peter.

33. John Chrysostom. Commentaries. ${ }^{731}$

a. Featured In: Paul.

34. John Chrysostom. Sermons. ${ }^{732}$

a. Featured In: John, Paul.

35. Leo I. Sermons. ${ }^{733}$

a. Featured In: Peter.

36. Marulus Spalatensis, Marcus.De institutione bene vivendi per exempla sanctorum. ${ }^{734}$

a. Featured In: Francis, Thomas Aquinas.

37. Nicephoros Callistus Xanthopulus. Ecclesiastical History. ${ }^{735}$

a. Featured In: John, James the Greater.

38. Panvinio, Onofrio. Ecclesiastic Chronicle. ${ }^{736}$

a. Featured In: John.

39. Peter Damian. O.S.B. Sermons. ${ }^{737}$

a. Featured In: John.

40. Possidius. Life of Augustine. ${ }^{738}$

a. Featured In: Augustine.

41. Prochorus. On the Life of John. ${ }^{739}$

a. Featured In: John.

42. Pseudo-Hegesippus. De exicidio Hierosolymitano. ${ }^{70}$

a. Featured In: Peter.

43. Sabellicus, Marcus Antonius. Enneades sive Rhapsodia historiarum. ${ }^{741}$

a. Featured In: Dominic.

44. Simon Metaphrastes. Menalogion. ${ }^{72}$

a. Featured In: Sebastian.

45. Sixtus IV. O.F.M. Bull for Bonaventure's Canonisation. ${ }^{743}$

a. Featured In: Bonaventure.

46. Surius, Laurentius. O. Cart. De probatis sanctorum historiis. ${ }^{74}$

a. Featured In: Bonaventure, Thomas Aquinas.

47. Tertullian. On the Soul. ${ }^{745}$

\footnotetext{
${ }^{730}$ Ibid. 213 r.

${ }^{731}$ Ibid. $216 \mathrm{r}$.

${ }^{732}$ Ibid. $216 \mathrm{r}, 421 \mathrm{r}$.

${ }^{733}$ Ibid. $210 \mathrm{v}$.

${ }^{734}$ Ibid. $127 \mathrm{v}, 342 \mathrm{v}$.

${ }^{735}$ Ibid. 238v, 420r, 421v

${ }^{736}$ Ibid. 423 r.

${ }^{737}$ Ibid. $423 \mathrm{r}$.

${ }^{738}$ Ibid. 299 r.

${ }^{739}$ Ibid. 421v, 422v.

${ }^{740}$ Ibid. $213 r$.

${ }^{741}$ Ibid. 264v.

${ }^{742}$ Ibid. 93 r.

${ }^{743}$ Ibid. 225 r.

${ }^{744}$ Ibid. $126 \mathrm{v}, 127 \mathrm{v}, 225 \mathrm{r}$.

${ }^{745}$ Ibid. fol. 421 .
} 
b. Featured In: John. 


\section{BIBLIOGRAPHY}

BCL - Chestnut Hill, MA, Boston College, O'Neill Library

BNE - Madrid, Biblioteca Nacional de Espana

HSA - New York, Hispanic Society of America

UTL - Toronto, University of Toronto Library

\section{Primary Sources}

\section{Works of Pedro de Ribadeneyra}

Ribadeneyra, Pedro de. Historia ecclesiastica del scisma del Reyno de Inglaterra. Antwerp: Christopher Plantin, 1588.

—. Tratado de la tribulacion. Alcalá: Juan Iñiguez de Lequerica, 1593.

- Tratado de la religion y virtudes que deue tener el Principe Christiano. Madrid: Pedro Madrigal, 1595.

- Flos sanctorum, o libro de las vidas de los santos. Fol. Madrid: Luis Sánchez, 1599. HSA.

- Segunda parte del Flos sanctorum, o Libro de las vidas de los santos. Fol. Madrid: Luis Sánchez, 1601. HSA.

- Flos sanctorum; o, Libro de las vidas de los Santos; en el qual se contienen las vidas de Christo nuestro Señor y de su santissima madre; y de todos los Santos de que reza la Iglesia Romana. Fol. Madrid: Luis Sánchez, 1604. UTL.

- Libro de vidas de santos que communmente llaman Extravagantes. Fol. Madrid: Luis Sánchez, 1604.

—. Illustrium sciptorum religionis Societatis Iesu catalogus. Antwerp: Plantin house, 1608.

- Segunda parte del Flos sanctorum, o Libro de las vidas de los santos. Fol. Madrid: Luis Sánchez, 1609. UTL.

- Catalogus sciptorum religionis Societatis Iesu. Antwerp: Plantin House, 1613.

- Confessiones, epistolae, aliaque scripta inedita. 2 vols. Madrid: La editorial Ibérica, 1920-1923. MHSI 58 and 60.

_ Vita Ignatii Loyolae. Ed. Cándido de Dalmases. Rome: Monumenta Historica Societatis Iesu, 1965. MHSI 93. 


\section{Other Flos sanctorum}

Villegas y Selvago, Alonso de. Flos sanctorum y historia general, de la vida y hechos de Jesu Christo, Dios y señor nuestro, y de todos los santos de que reza y haze fiesta la iglesia catholica confrome al brevario romano, reformado por decreto del sancto concilio Tridentino, junto con las vidas de los sanctos proprios de Espana, $y$ de otros extravagantes. Fol. Madrid: Pedro Madrigal, 1588. BNE

- Flos Sanctorum: segunda parte: y historia general en que se escrive la vida de la Virgen Sacratissima Madre de Dios, y Señora Nuestra y las de los santos antiguos que fueron antes de la venida de nuestro salvador al mundo. Fol. Alcalá de Henares: Andrés Sánchez de Ezpeleta, 1609. BNE.

Vega, Pedro de la. Flos sanctorum: la vida de nuestro señor Jesu Christo: y de su sanctissima madre: $y$ de los otros santos segun la orden de sus fiestas. Rev. Martin de Lillio. Fol. Alcalá de Henares: Juan Brocar, 1558. BCL.

- Flos sanctorum: la vida de nuestro señor Jesu Christo: y de su sanctissima madre: $y$ de los otros santos segun la orden de sus fiestas. Rev. Martin de Lillio. Fol. Alcalá de Henares: Juan Brocar, 1572.

\section{Other Hagiographies}

Bonaventure. "Vita Francisci." In Acta sanctorum Octrobris, 2: 742-98. Paris and Rome: Victor Palmé, 1866.

Cianca, Antonio de. Historia de la vida, invención, milagros, y translación de San Segundo, primero obsipo de Avila. Madrid: Luis Sanchez, 1595.

Foxe, John. Actes and monuments of these latter and perilous days, (1563 edition). [online]. (hriOnline, Sheffield). Available from: http://www.hrionline.shef.ac.uk/foxe/, [Accessed: 28.06.2011]

Major, Georg. Vitae patrum in usum ministrorum verbi quo ad eius fieri potuit reprugare. Wittenberg: [Seitz], 1544.

Horche, Juan de. Historia de la vida de San Frutos, patrón de la Ciudad de Segovia y sus hermanos San Valentín y Santa Engracia. Valladolid: C. Lasso Vaca, 1610.

Lippomano, Luigi. Sanctorum priscorum partum vitae numero centum sexagintatres, per gravissimos et probatissimos auctores conscriptae. Venice: Segno della Speranza, 1551 .

- Secundus tomus vitarum Sanctorum priscorum partum vitae numero ducentum et vigintiquinque, per gravissimos et probatissimos auctores conscriptae. Venice: Segno della Speranza, 1553. 
- Vitarum Sanctorum priscorum patrum per gravissimos auctores consriptarum. Venice: Segno della Speranza, 1554.

Melanchton, Philip. "History of the Life and Acts of Dr. Martin Luther." In Luther's Lives, eds. Elizabeth Vandiver, Ralph Keen, and Thomas D. Frazel, 14-39. New York: Manchester University Press, 2001.

Surius, Laurentius. Historiae seu vitae sanctorum juxta optimam coloniensem editionem. 13 vols. Turin: P. Marietto, 1875-1880.

Vega Carpio, Lope de. Isidro. Madrid: Luis Sánchez, 1599.

Villegas y Selvago, Alonso de. Vida de Isidro Labrador, cuyo cuerpo está en la iglesia parroquial de San Andrés de Madrid. Madrid: Luis Sánchez, 1592.

\section{Jesuit Sources}

"Acta Patris Ignatii scripta a Lud[ovico] Gonzalez de Camara 1553/1555." In Fontes narrativi de S. Ignatio de Loyola et de Societatis Iesu Initiis, eds. Denis Fernandez Zapico and Candido de Dalmases, 1:323-507. Rome: Monumenta Historica Societatis Iesu, 1943. MHSI 66.

Acta sanctorum Junii. Antwerp: Peter Jacobs, 1707.

Directoria Exercitiorum Spiritualium (1540-1599). Ed. Ignacio Iparraguirre. Rome: Monumenta Historica Societatis Iesu, 1955. MHSI 76.

"Ratio atque institutio studiorum Societatis Iesu (1599)." In Ratio atque institution studiorum Societatis Iesu, ed. Ladislaus Lukács, 355-454. Rome: Institutum Historicum Societatis Iesu, 1986. MHSI 129.

Regulae Societatis Iesu. Tarragona: Felipe Mey, 1583.

Arias, Francisco. Libro de la imitacion de Christo nuestro Señor. Seville: Clemente Hidalgo, 1599.

Borja, Francisco de. Tratados Espirituales. Barcelona: J. Flores, 1964.

Canisius, Peter. Opus catechisticum. Cologne: Geruinus Calenius and descendents of Johann Quentelius, 1577.

Clavius, Christopher. Opera mathematicorum. 5 vols. Mainz: Johann Volmar, 1612.

Ignatius of Loyola. Epistolae et instructiones. 12 vols. Madrid: Gabriel López del Horno, 1903-11. MHSI 22, 26, 28, 29, 31, 33, 34, 36, 37, 39, 40, and 42. 
- "Ephermeris S.N. Ignatii." In Constitutiones Societatis Iesu, 1:86-158. Rome: Gregorian Pontifical University, 1934. MHSI 63.

- Constitutiones Societatis Iesu, vol. 2. Rome: Monumenta Historica Societatis Iesu, 1936. MHSI 64.

- Exercitia Spiritualia. Eds. Josephus Calverus and Candido de Dalmases. Rome: Institutum Historicum Societatis Iesu, 1969. MHSI 100.

López, Cristóbal. "Vida del Padre Pedro de Ribadeneyra, Religioso de la Compañía de Jesús...En Madrid año de 1612." In Pedro de Ribadeneyra, Confessiones, epistolae, aliaque scripta inedita, ed. Daniel Restrepo, 2:429-88. Madrid: La editorial Ibérica, 1923.

Mariana, Juan de. Historiae de rebus hispaniae libri xx. Toledo: Pedro Roderigo, 1592.

Nadal, Jerónimo. Epistolae P. Hieronymi Nadal. 6 vols. Madrid: Augustino Avrial, 18981964. MHSI 3, 15, 21, 27, 90, and 90a.

- "Adhortationes Complutenses 1561." In Fontes narrative de S. Ignatio de Loyola et de Societatis Iesu Initiis, ed. Candido de Dalmases, 2:160-204. Rome: Monumenta Historica Societatis Iesu, 1951. MHSI 73.

Polanco, Juan-Alfonso de. Vita Ignatii Loiolae et rerum Societatis Jesu historia. 6 vols. Madrid: Typographorum Societas, 1894-98. MHSI 1, 3, 5, 7, 9, and 11.

Possevino, Antonio. Bibliotheca selecta. Rome: Typographica Apostolica Vaticana, 1593.

Rodríguez, Alonso. Exercicio de perfeción y virtudes cristianas. 3 vols. Seville: Matias Cavijo, 1609-1616.

\section{Ecclesiastic Sources}

Breviarium Romanum. Editio princeps (1568). Eds. M. Sodi and A.M. Triacca. Vatican City: Libreria editrice vaticana, 1999.

Canons and Decrees of the Council of Trent. Trans. H.J. Schroeder. St. Louis and London: Herder Book Co., 1941.

Catechism of the Council of Trent. Trans. J. Donovan. Dublin: W. Folds and Son, 1829.

"Concilio Provincial de Toledo, año 1565 a 1566: Sesión III - De Reforma." In Colección de los Cánones y de todos los concilios de la Iglesia de España y América, ed. Juan Tejada y Ramiro, 5:243-60. Madrid: Pedro Montero, 1863. 
Liber pontificalis. Trans. Raymond Davis. Liverpool: Liverpool University Press, 2000.

Martyrologium Romanum. Editio princeps (1584). Eds. M. Sodi and R. Fusco. Vatican City: Libreria editrice vaticana, 2005.

Index de l'Inquisition espagnole 1551, 1554, 1559. Ed. J.M. de Bujanda. Sherbrooke, PQ and Geneva: Centre d'Études de la Renaissance and Librairie Droz, 1984.

Index de l'Inquisition espagnole 1583, 1584. Ed. J.M. de Bujanda. Sherbrooke and Geneva: Centre d'Études de la Renaissance and Librairie Droz, 1993.

\section{Sources on the Cultural Life of Early Modern Spain}

Diccionario de la lengua castellana. Madrid: Viuda de Francisco del Hierro, 1732.

Relaciones histórico-geográfico-estadísticas de los pueblos de España hechas por iniciativa de Felipe II. Eds. Carmelo Viñas y Mey and Ramón Paz. 3 vols. Madrid: Consejo Superior de Investigaciones Científicas, 1949.

Aesop. La vida y las fabulas del Esopo. Antwerp: Plantin house, 1607.

Cervantes Saavedra, Miguel de. Don Quijote de la Mancha. Madrid: Cupsa Editorial, 1977.

Diago, Francisco. Historia de la vida exemplar libros, y mverte, del insigne y celebre maestro F. Luys de Granada. Barcelona: Sebastian de Cormellas, 1605.

El Greco. Fray Hortensio Félix Paravicino. 1609. Boston Museum of Fine Arts.

Guevara, María de. "Desengaños de la corte, y mujeres valerosas." In Warning to the Kings and Advice on Restoring Spain: A Bilingual Edition. Ed. and trans. Nieves Romero-Díaz, 64-111. Chicago and London: University of Chicago Press, 2007.

Isidore of Seville. "De ortu, \& obitu Patrum." In Opera, 2 vols., 1:†139-†154. Madrid: Imprenta Real, 1599.

Quevedo, Francisco de. La vida del Buscón llamado Don Pablos. Salamanca: Consejo superior de investigaciones cientificas, 1965

Quintana, Gerónimo de. La historia del origen, antiguedad, nobleza y grandeza de Madrid. Madrid: Imprenta Real, 1629.

Quixada, Tomás. "Consulta." in Bartolomé Villalba y Estaña, El Pelegrino Curioso y Grandezas de España, 1:7-71. Madrid: Miguel Ginesta, 1886. 
Teresa de Ávila. Libro de la vida. Madrid: Taurus, 1982.

Vega Carpio, Lope de. Fuenteovejuna. Ed. Donald McGrady. Barcelona: Crítica, 1993.

Vives, Juan Luis. De disciplinis libris XII, septem de Corruptis Artibus; quinque de tradendis Disciplinis. Naples : Typographia Simonia, 1764.

Zurbarán, Francisco. Saint Bonaventure refers Saint Thomas Aquinas to the Saviour. 1629. Kaiser Friedrich Museum.

Augustine. Confessions. Trans. R.S. Pine-Coffin. London: Penguin, 1961.

- Tractates on the Gospel of John. Trans. John W. Rettig. 5 vols. Washington, D.C.: Catholic University of America Press, 1993.

\section{Other Sources}

Baronius, Cesar. Annales Ecclesiastici. 10 vols. Rome: Typographica Vaticana, 15881602.

Bruni, Leonardo. "The Study of Literature." In Humanist Educational Treatises, ed. and trans. Craig W. Kallendorf, 92-125. Cambridge, MA, and London: Harvard University Press, 2002.

Erasmus, Desiderius. "The Young Man and the Harlot." In Collected Works of Erasmus, vol. 39, Colloquies, trans. Craig R. Thompson, 381-389. Toronto, Buffalo, and London: University of Toronto Press, 1997.

Gregory of Tours. Glory of the Martyrs. Trans. Raymond van Dam. Liverpool: Liverpool University Press, 1988.

Jerome. "Liber duo adversus Jovinianum." In Patrologiae cursus completus: Series latina, 23: 211-338. Paris: Vrayet, 1844-96.

Luther, Martin. “D. Martinus Luther, pio lectori salutem.” In Georg Major, Vitae patrum in usum ministrorum verbi quo ad eius fieri potuit reprugare, A1v-A4r. Wittenberg: [Seitz], 1544.

Sixtus of Siena. Bibliotheca santa. Venice: Francesco Francesci, 1566.

Thomas Kempis. The Imitation of Christ. Trans. Leo Sherley-Price. Harmondsworth: Penguin, 1956.

Trithemius, Johannes. De scriptoribus ecclesiasticis. Basel: Amerbach 1494.

Translations for Reference 
Cervantes Saavedra, Miguel de. The Ingenious Hidalgo Don Quixote de la Mancha. Trans. John Rutherford. London: Penguin, 2003.

Ignatius of Loyola. The Constitutions of the Society of Jesus. Trans. George Ganss. St. Louis: Institute of Jesuit Sources, 1970.

Rodríguez, Alonso. Practice of Christian Perfection and Christian Virtues. 3 vols. Trans. Joseph Rickaby. Chicago: Loyola University Press, 1929.

Teresa of Ávila. The Life of Saint Teresa of Ávila by Herself. Trans. J.M. Cohen. London: Penguin, 1957.

\section{$\underline{\text { Secondary Sources }}$}

Autobiography in Early Modern Spain. Eds. Nicholas Spadaccini and Jenaro Talens. Minneapolis: Prisma Institute, 1988.

The Jesuits: Cultures, Sciences, and the Arts, 1540-1773. Eds. John W. O'Malley et al. Toronto: University of Toronto Press, 1999.

The Jesuits II: Cultures, Sciences, and the Arts, 1540-1773. Eds. John W. O'Malley et al. Toronto: University of Toronto Press, 2006.

Penitence in the Age of Reformations. Eds. Katharine Jackson Lualdi and Anne T. Thayer. Aldershot: Ashgate, 2000.

The Reformation and the Book. Ed. Jean-François Gilmont. Trans. Karin Maag. Aldershot: Ashgate, 1998.

Aigrain, René. L'hagiographie: ses sources-ses méthodes-son histoire. Paris: Bloud et Gay, 1953. Reprint, Brussels: Société des Bollandistes, 2000.

Alhgren, Gillian W.T. Teresa of Avila and the Politics of Sanctity. Ithaca, NY: Cornell University Press, 1996.

Allen, Michael I. "Universal History 300-1000." In Historiography in the Middle Ages, ed. Deborah Mauskopf Deliyannis, 17-42. Brill: Leiden and Boston, 2003.

Anderson, Benedict. Imagined Communities. Rev. ed. London and New York: Verso, 1983. Reprint, 2006.

Aragüés Aldaz, José. Deus concionator: Mundo predicado y retorica del exemplum en los Siglos de Oro. Amsterdam and Atlanta, GA: Rodopi, 1999. 
- "Tendencias y realizaciones en el campo de la hagiografía en Espana: con algunos datos para el estudio de los legendarios hispanicos." Memoria Ecclesiae 24 (2004): 441-560.

Astrain, Antonio. Historia de la Compañía de Jesús en la asistencia de España. $2^{\text {nd }}$ ed. 7 vols. Madrid: Razón y Fe, 1912-1925.

Backus, Irena. Historical Method and Confessional Identity in the Era of the Reformation. Leiden and Boston: Brill, 2003.

- Life Writing in Reformation Europe: Lives of Reformers by Friends, Disciples, and Foes. Aldershot: Ashgate, 2008.

Bailey, Gauvin Alexander. Art on the Jesuit Missions in Asia and Latin America, 15421773. Toronto, Buffalo, and London: University of Toronto Press, 1999.

- Between Renaissance and Baroque: Jesuit Art in Rome, 1565-1610. Toronto, Buffalo, London: University of Toronto Press, 2003.

Baldwin, Martha. "Pious Ambition: Natural Philosophy and the Jesuit Quest for the Patronage of Printed Books in the Seventeenth Century." In Jesuit Science and the Republic of Letters, ed. Mordechai Feingold, 285-329. Cambridge, MA, and London: MIT Press, 2003.

Balsamo, Luigi. "How to Doctor a Bibliography: Antonio Possevino's Practice." In Church, Censorship, and Culture in Early Modern Italy, ed. Gigliola Fragnito, trans. Adrian Belton, 50-78. Cambridge and New York: Cambridge University Press, 2004.

Bangert, William V. A History of the Society of Jesus. St. Louis: Institute of Jesuit Sources, 1972.

- Jerome Nadal, S.J., 1507-1580: Tracking the First Generation of Jesuits. Chicago: Loyola University Press, 2002.

Baños Vallejo, Fernando. La hagiografia como género literario en la Edad Media. Oviedo: Departamento de Filología Española, 1989.

- Las vidas de santos en la literatura medieval española. Madrid: Ediciones del Laberinto, 2003.

Bataillon, Marcel. Érasme et l'Espagne: Recherches sur l'histoire spirituelle du XVIe siècle. Paris: Droz, 1937.

- Erasmo y España: Estudios sobre la historia espirituel del siglo XVI, $2^{\text {nd }}$ ed. México: Fondo de Cultura Económica, 1966. 
Bartolomé Martínez, Bernabé. "Las librerías e imprentas de los Jesuitas, 1540-1767." Hispania Sacra 40 (1988): 315-88.

Benedict, Philip. "Confessionalization in France? Critical Reflections and New Evidence." In The Faith and Fortunes of France's Huguenots, 1600-1685, 30926. Aldershot: Ashgate, 2001.

Berger, Philippe. Libro y lectura en la Valencia del Renacimiento. 2 vols. Valencia: Edicions Alfons el Magnànim, 1987.

Bertrand, Dominique. "The Society of Jesus and the Church Fathers." In The Reception of the Church Fathers in the West, 2 vols., ed. Irena Dorota Backus, 2:889-950. Leiden and Boston: Brill, 1995.

Bilinkoff, Jodi. “The Many 'Lives' of Pedro de Ribadeneyra." Renaissance Quarterly 52, no. 1 (Spring 1999): 180-196.

- Related Lives: Confessors and Their Female Penitents, 1450-1750. Ithaca, NY: Cornell University Press, 2005.

Boeckl, Christine M. "Plague Imagery as Metaphor for Heresy in Rubens' The Miracle of Saint Francis Xavier." Sixteenth Century Journal 27, no. 4 (1996): 979-95.

Boss, Julia. "Writing a Relic: the Use of Hagiography in New France." In Colonial Saints: Discovering the Holy in Americas, 1500-1800, eds. Allan Greer and Jodi Bilinkoff, 211-34. New York: Routledge, 2003.

Bossy, John, "The Mass as a Social Institution, 1200-1700," Past and Present 100, no. 1 (1983): 29-61.

Bouza, Fernando. Corre Manuscrito. Madrid: Marcial Pons, 2001.

- Communication, Knowledge, and Memory in Early Modern Spain. Trans. Sonia López and Michael Agnew. Philadelphia: University of Pennsylvania Press, 2004.

Brann, Noel L. The Abbot Trithemius (1462-1516): The Renaissance of Monastic Humanism. Leiden: Brill, 1981.

Brown, Peter. "The Saint as Exemplar in Late Antiquity." Representations 2 (1983): 125.

Burke, Peter. "How to be a Counter-Reformation Saint." In The Counter-Reformation: The Essential Readings, ed. David M. Luebke, 129-42. Malden, MA: Blackwell, 1999. 
_. "Exemplarity and Anti-exemplarity in Early Modern Europe." In The Western Time of Ancient History, ed. Alexandra Lianeri, 48-59. Cambridge: Cambridge University Press, 2011.

Bussell Thompson, Billy, and John Walsh. "Old Spanish Manuscripts of Prose Lives of the Saints and their Affiliation. I: Compilation A (Gran Flos sanctorum)." La Corónica 15, no. 1 (1986-87): 17-28.

Bussell Thompson, Billy. “Plumbei cordis, oris ferrei:' la recepción de la teología de Jacobus a Voragine y su Legenda aurea en la Península." In Saints and their Authors, eds. Jane E. Connolly, Alan Deyermond, Brian Dutton, 97-106. Madison: Hispanic Seminary of Medieval Studies, 1990.

Cameron, Euan. Enchanted Europe: Superstition, Reason, and Religion, 1250-1750. Oxford and New York: Oxford University Press, 2010.

Carrasco, Raphaël. "Loin des enfers: littérature hagiographique et propagande dans l'Espagne classique (XVIe et XVIIe siècle)." In Enfers et damnations dans le monde hispanique et hispano-américain, eds. Jean-Paul Duviols and Annie Molinié-Bertrand, 363-381. Paris: Presses universitaires de France, 1996.

Castillo Gómez, Antonio. "La biblioteca interior: experiencias y representatciones de la lectura en las autobiografías, memorias, y diarios del Siglo de Oro." In La Memoria de los libros, eds. Pedro M. Cátedra and María Luisa López-Vidriero, 2 vols., 2:15-50. Salamanca : Instituto de Historia del Libro y de la Lectura, 2004.

Certeau, Michel de. The Practice of Everyday Life. Trans. Steven Rendall. Berkeley, CA: University of California Press, 1984.

- The Writing of History. Trans. Tom Conley. New York: Columbia University Press, 1988.

- The Mystic Fable. 2 vols. Trans. Michael B. Smith. Chicago: University of Chicago Press, 1992.

Chartier, Roger. "Leisure and Sociability: Reading Aloud in Early Modern Europe." In Urban Life of the Renaissance, eds. Susan Zimmerman and Ronald F.E. Weissman, 103-20. Newark, DE: University of Delaware Press, 1989.

- The Order of Books. Trans. Lydia G. Cochrane. Stanford, CA: Stanford University Press, 1994.

—_. "Reading Matter and 'Popular' Reading: From the Renaissance to the Seventeenth Century." In A History of Reading in the West, eds. Guglielmo Cavallo and Roger Chartier, 269-83. Amherst, MA: University of Massachusetts Press, 1999. 
Chevalier, Maxime. Lectura y lectores en la España del siglos XVI y XVII. Madrid: Ediciones Turner, 1976.

Chipps Smith, Jeffrey. Sensous Worship: Jesuits and the Art of the Early Catholic Reformation in Germany. Princeton and Oxford: Princeton University Press, 2002.

Collins, David J. Reformed Saints: Saints' Lives and their Authors in Germany, 14701530. New York: Oxford University Press, 2008.

Courcelles, D. de. "Espagne de 1450 à 1550." In Hagiographies, ed. Guy Philipart, 1:155-188. Turnhout: Brepols, 1994.

Dadson, Trevor J. Libros, lectores y lecturas: Estudios sobre bibliotecas particulares españolas del Siglo de Oro. Madrid: Arco/Libros, 1998.

Darnton, Robert. The Great Cat Massacre and Other Episodes in French Cultural History. New York: Vintage Books, 1985.

- The Kiss of Lamourette: Reflections on Cultural History. New York: W.W. Norton \& Company, 1990.

Defourneaux, Marcelin. Daily Life in Spain in the Golden Age. Trans. Newton Branch. London: George Allen and Unwin, 1970.

Ditchfield, Simon. "How Not to be a Counter-Reformation Saint: The Attempted Canonization of Pope Gregory X, 1622-45." Papers of the British School at Rome 60 (1992): 379-422.

- Liturgy, Sanctity, and History in Tridentine Italy: Pietro Maria Campi and the Preservation of the Particular. Cambridge: Cambridge University Press, 1995.

—. "'Historia magistra sanctitatis?' The Relationship between Historiography and Hagiography in Italy after the Council of Trent (1564-1742 ca.)." Studies in Medieval and Renaissance History 3, 3rd series (2006): 159-84.

- "Thinking with the Saints: Sanctity and Society in the Early Modern World." Critical Inquiry 35, no. 3 (Spring 2009): 552-84.

—_. "Coping with the 'Beati Moderni': Canonization Procedure in the Aftermath of the Council of Trent." In Ite inflammate omnia, ed. Thomas M. McCoog, 413-39. Rome: Institutum historicum Societatis Iesu, 2010.

Driver, Steven D. John Cassian and the Reading of Egyptian Monastic Culture. New York and London: Routledge, 2002. 
Dubois, Jacques. Le martyrologe d'Usuard: Texte et commentaire. Brussels: Société des Bollandistes, 1965.

Dunn-Lardeau, Brenda. "De La Légende dorée de Jacques de Voragine aux Fleurs des vies des saints de Pedro de Ribadeneira." In Les voies de l'invention aux XVIe et XVIIe siècles, eds. Bernard Beugnot and Robert Melançon, 23-34. Montréal: Université de Montréal, 1993.

Egido, Teófanes. "Hagiografia y estereotipos de santidad contrereformista." Cuadernos de Historia Moderna 25 (2000): 61-85.

Eisenstein, Elizabeth L. The Printing Press as an Agent of Change: Communications and Cultural Transformations in Early-Modern Europe. 2 vols. Cambridge: Cambridge University Press, 1979.

Fatás, Guillermo. "La santidad y sus antecedentes. Santos antiguos y santos anómalos." Revista de Historia Jerónimo Zurita 85 (2010): 13-38.

Febvre, Lucien, and Henri-Jean Martin. The Coming of the Book. Trans. David Gerard. New ed. London: Verso, 1997.

Filippi, Bruna. "The Orator's Performance: Gesture, Word, and Image in Theatre at the Collegio Romano," in The Jesuits 1I: Cultures, Sciences, and the Arts, 1540-1773, eds. John W. O'Malley et al., 512-29. Toronto: University of Toronto Press, 2006.

Foot, Sarah. "Finding the Meaning of Form: Narrative in Annals and Chronicles." In Writing Medieval History, ed. Nancy Partner, 88-108. London: Hodder, 2005.

Frazier, Alison Knowles. Possible Lives: Authors and Saints in Renaissance Italy. New York: Columbia University Press, 2005.

Frenk, Margit. "Lectores y oidores: La difusión oral de la literatura en el Siglo de Oro." In Actas del VII Congreso de la Asociación Internacional de Hispanistas. 2 vols., 1:101-123. Rome: Bulzoni, 1982.

Friedrich, Markus. "Circulating and Compiling the Litterae Annuae. Towards a History of the Jesuit History of Communication." Archivum Historicum Societatis Iesu 153, 77 (2008): 3-39.

Gagnon, François-Marc. La conversion par l'image: un aspect de la mission des Jésuites auprès des Indiens du Canada au XVIIe siècle. Montréal: Bellarmin, 1975.

García Carcel, Ricardo. "Las relaciones de la monarquía de Felipe II con la Compañía de Jesús." In Felipe II y el Mediterráneo, 4 vols., ed. Ernest Belenguer Cebrià, 2: 
219-41. Madrid: Sociedad Estatal para la Conmemoración de los Centenarios de Felipe II y Carlos V, 1999.

Gaskell, Philip. A New Introduction to Bibliography. Oxford: Clarendon Press, 1972 [1985].

Gilmont, Jean-François. Les écrits spirituels des premiers Jésuites. Rome: Institutum Historicum Societatis Iesu, 1961.

Godman, Peter. The Saints as Censor: Robert Bellarmine between Inquisistion and Index. Leiden: Brill, 2000.

Goffart, Walter. The Narrators of Barbarian History. Princeton, NJ: Princeton University Press, 1988.

Gómez Zorraquino, José Ignacio. "Los santos patrons y la identidad de las comunidades locales en la España de los siglos XVI y XVII." Revista de Historia Jerónimo Zurita 85 (2010): 39-74.

Grafton, Anthony. The Footnote: A Curious History. Cambridge, MA: Harvard University Press, 1997.

- What was History? The Art of History in Early Modern Europe. Cambridge: Cambridge University Press, 2007.

Greer, Alan. "Colonial Saints: Gender, Race, and Hagiography in New France." The William and Mary Quarterly 57, no. 2 (April 2000): 323-48.

- Mohawk Saint: Catherine Tekakwitha and the Jesuits. Oxford: Oxford University Press, 2005.

Grendler, Paul. "Form and Function in Italian Renaissance Popular Books." Renaissance Quarterly 46, no. 3 (Autumn 1993): 451-85.

Griffin, Clive. Journeymen-printers, Heresy, and the Inquisition in Sixteenth Century Spain. Oxford: Oxford University Press, 2005.

Guggisberg, Hans R. Sebastian Castellio, 1515-1563: Humanist and Defender of Religious Tolerance in a Confessional Age. Trans. Bruce Gordon. Aldershot: Ashgate, 2003.

Haugen, Kristine Louise. "A French Jesuit's Lectures on Vergil, 1582-1583: Jacques Sirmond between Literature, History, and Myth." Sixteenth Century Journal 30, no. 4 (1999): 967-85.

Head, Thomas. Medieval Hagiography. New York: Routledge, 2001. 
Høgel, Christian. Symeon Metaphrastes: Rewriting and Canonization. Copenhagen: Museum Tusculanum Press, 2002.

Homza, Lu Ann. Religious Authority in the Spanish Renaissance. Baltimore and London: Johns Hopkins University Press, 2000.

- "The Merits of Disruption and Tumult: New Scholarship on Religion and Spirituality in Spain during the Sixteenth Century." Archiv für Reformationsgeschite 100 (2009): 218-34.

Houston, R.A. Literacy in Early Modern Europe. New York and London: Longman, 1988.

Hsia, Florence. Sojourners in a Strange Land: Jesuits and their Scientific Missions in Late Imperial China. Chicago: University of Chicago Press, 2009.

Hsia, R. Po-Chia. Social Discipline in the Reformation, Central Europe 1550-1750. London and New York: Routledge, 2002.

Jedin, Hubert. "Catholic Reformation or Counter Reformation?" In The CounterReformation: The Essential Readings, ed. David M. Luebke, 19-45. Malden, MA: Blackwell, 1999.

Johns, Adrian. The Nature of the Book: Print and Knowledge in the Making. Chicago: University of Chicago Press, 1998.

Julia, Dominique. "Reading and the Counter-Reformation." In A History of Reading in the West, eds. Guglielmo Cavallo and Roger Chartier, 238-68, trans. Lydia S. Cochrane. Amherst, MA: University of Massachusetts Press, 1999.

Kagan, Richard L. Students and Society in Early Modern Spain. Baltimore and London: Johns Hopkins University Press, 1974.

- Lucrecia's Dreams: Politics and Prophecy in Sixteenth-Century Spain. Berkeley, CA, Los Angeles, and London: University of California Press, 1990.

- Clio \& the Crown: The Politics of History in Late Medieval and Early Modern Spain. Baltimore: Johns Hopkins University Press, 2009.

Kamen, Henry. The Spanish Inquisition. London: Weidenfield and Nicolson, 1968.

King, Margaret L. Venetian Humanism in an Age of Patrician Dominance. Princeton: Princeton University Press, 1986.

Knowles, David. Great Historical Enterprises. London: Nelson, 1963. 
Kolb, Robert. For All the Saints: Changing Perceptions of Martyrdom and Sainthood in the Lutheran Reformation. Macon, GA: Mercer University Press, 1987.

Kowal, David M. "Innovation and Assimilation: The Jesuit Contribution to Architectural Development in Portuguese India." In The Jesuits: Cultures, Sciences, and the Arts, 1540-1773, eds. John W. O'Malley et al., 480-504. Toronto: University of Toronto Press, 1999.

Lapôtre, M.A. "Le Souper de Jean Diacre." Mélanges d'archéologie et d'histoire 21 (1901): 305-85.

Lawrence, C.H. Medieval Monasticism. $3^{\text {rd }}$ ed. Harlow: Pearson, 2001.

Lazar, Lance. "The Formation of the Pious Soul: Transalpine Demand for Jesuit Devotional Texts, 1548-1615." In Confessionalization in Europe, 1555-1700, eds. John M. Headley, Hans Hillerbrand, and Anthony J. Papalas, 289-318. Aldershot: Ashgate, 2004.

Leturia, Pedro de. Estudios ignacianos. Ed. Ignacio Iparraguirre. 2 vols. Rome: Institutum Historicum Societatis Iesu, 1957.

Loz-Heumann, Ute. "Confessionalization." In Reformation and Early Modern Europe: A Guide to Research, ed. David M. Whitford, 136-157. Kirksville, MI: Truman State University, 2008.

Marshall, Peter, and Alexandra Walsham. "Migrations of Angels in the Early Modern World." In Angels in the Early Modern World, eds. Peter Marshall and Alexandra Walsham, 1-40. Cambridge and New York: Cambridge University Press, 2006.

Martín Abad, Julián. La imprenta en Alcalá de Henares: 1502-1600. 3 vols. Madrid: Arco/ Libros, 1991.

Martínez de la Escalera, José. "Casiano, el Cerratense y Pedro de la Vega OSH." Hispania sacra 47, no. 96 (1995): 681-93.

Maryks, Robert. Saint Cicero and the Jesuits. Aldershot: Ashgate, 2008.

—. The Jesuit Order as a Synagogue of Jews. Leiden: Brill, 2010.

Mayer, Thomas F. and D.R. Woolf. "Introduction." In The Rhetorics of Life-Writing in Early Modern Europe, eds. Thomas F. Mayer and D.R. Woolf, 1-37. Ann Arbor, MI: University of Michigan Press, 1995.

McKitterick, Rosamond. History and Memory in the Carolingian World. Cambridge: Cambridge University Press, 2004. 
Meier, Christel. "Organisation of Knowledge and Encyclopedia Ordo: Functions and Purposes of a Universal Literary Genre." In Pre-Modern Encyclopedic Texts, ed. Peter Binkley, 103-26. Leiden: Brill, 1997.

Moreschini, Claudio, and Enrico Norelli. Early Christian Greek and Latin Literature: A Literary History. Trans. Matthew J. O'Connell. 2 vols. Peabody, MA: Hendrickson Publishers, 2005.

Mormondo, Franco. "Pestilence, Apostasy, and Heresy in Seventeenth-Century Rome." In Piety and Plague: From Byzantium to the Baroque, eds. Franco Mormondo and Thomas Worcester, 237-312. Kirksville, MO: Truman State University Press, 2007.

Nalle, Sara T. "Literacy and Culture in Early Modern Castile." Past and Present 125, no. 1 (1989): 65-96.

" "A Saint for All Seasons: The Cult of San Julián." In Culture and Control in Counter-Reformation Spain, eds. Anne J. Cruz and Mary Elizabeth Perry, 25-50. Minneapolis and Oxford: University of Minnesota Press, 1992.

. "Printing and Reading Popular Religious Texts in Sixteenth-Century Spain." In Culture and the State in Spain: 1550-1850, eds.Tom Lewis and Francisco J. Sanchez, 126-56. New York: Garland Publishing, 1999.

Nelles, Paul. "Historia magistra antiquitatis: Cicero and Jesuit History Teaching." Renaissance Studies 13, no. 2 (1999): 130-72.

- "Three Audiences for Religious Books in Sixteenth-Century France." In The Sixteenth-Century Religious French Religious Book, eds. Andrew Pettegree, Paul Nelles, and Philip Conner, 256-85. Aldershot: Ashgate, 2001.

- "Du savant au missionnaire: la doctrine, les mœurs et l'écriture de l'histoire chez les Jésuites." XVIIe siècle 237 (2007): 669-89.

. "Libros de papel, libri bianchi, libri papyracei. Note-taking Techniques and the Role of Student Notebooks in the Early Jesuit Colleges." Archivum Historicum Societatis Iesu 76 (2007): 75-112.

- "Reading and Memory in the Universal Library: Conrad Gesner and the Renaissance Book." In Ars reminiscendi: Mind and Memory in Renaissance Culture, eds. Donald Beecher and Grant Williams, 148-69. Toronto: Centre for Reformation and Renaissance Studies, 2009.

. "Seeing and Writing: The Art of Observation in the Early Jesuit Missions." Intellectual History Review 20, no. 3 (2010): 317-33. 
Noreen, Kirstin. "Ecclesiae militantis triumphi: Jesuit Iconography and the CounterReformation." Sixteenth Century Journal 29, no. 3 (1998): 689-715.

O'Malley, John W. The First Jesuits. Cambridge, MA and London: Harvard University Press, 1993.

- "Was Ignatius Loyola a Church Reformer? How to Look at Early Modern Catholicism." In The Counter-Reformation: The Essential Readings, ed. David M. Luebke, 65-82. Malden, MA: Blackwell, 1999.

—_. "The Historiography of the Society of Jesus." In The Jesuits: Cultures, Sciences, and the Arts, 1540-1773, eds. John W. O'Malley et al., 3-37. Toronto: University of Toronto Press, 1999.

Osswald, Maria Cristina. "The Iconography and Cult of Francis Xavier, 1552-1640." Archivum Historicum Societatis Iesu 71, no. 142 (2002): 259-77.

Peraita, Carmen. "Marginalizing Quevedo: Reading Notes and the Humanistic Persona." In Reading Notes, eds. Dirk Van Hulle and Wim Van Mierlo, 37-60. Amsterdam and New York: Rodopi, 2004.

Palmer, Nigel F. "Exempla." In Medieval Latin, eds. F.A.C. Mantello and A.G. Rigg, 582-88. Washington, D.C.: Catholic University of America Press, 1999.

Palomo, Federico. “'Disciplina christiana': Apuntes historiográficos en torno a la disciplina y el disciplinamiento social como categorías de la historia religiosa de la alta edad moderna." Cuadernos de Historia Moderna 18 (1997): 119-36.

- - "Corregir letras para unir espíritus. Los jesuitas y las cartas edificantes en el Portugal del siglo XVI." Cuadernos de Historia Moderna. Anjeos 4 (2005): 57 81.

Pardo Tomás, José. Ciencia y censura: la inquisición española y los libros cientificos en los siglos xvi y xvii. Madrid: Consejo Superior de Investigaciones Científicas, 1991.

Peña Díaz, Manuel. "Religiosidad y libros 'populares' en el siglo XVI." In Política, religión e inquisición en la España moderna, ed. Pablo Fernández Albaladejo et al., 529-47. Madrid: Universidad Autónoma de Madrid, 1996.

Petrucci, Armando. "Alli origini del libro moderno. Libri da banco, libri di bissacia, libretti da mano." Italia medioevale e umanistica 12 (1969): 295-313.

Pinto Crespo, Virgilio. Inquisición y control ideológico en la España del siglo xvi. Madrid: Taurus, 1983. 
Poska, Allyson M. "Confessionalization and Social Discipline in the Iberian World." Archiv für Reformationsgeschite 94 (2003): 308-19.

Prieto Bernabé, José Manuel. Lecturas y lectores: La cultura del impreso en el Madrid del Siglo de Oro (1550-1650). 2 vols. Merida: Editora Regional de Extremadura, 2004.

Pullapilly, Cyriac K. Caesar Baronius: Counter-Reformation Historian. Notre Dame, $\mathrm{IN}$, and London: Notre Dame University Press, 1975.

Quentin, Henri. Les martyrologes historiques du moyen age. 1908. Reprint, Darmstadt: Scientia Verlag Aalen, 1969.

Rawlings, Helen. Church, Religion, and Society in Early Modern Spain. New York: Palgrave, 2002.

Reames, Sherry L. The Legenda aurea: A Reexamination of Its Paradoxical History. Madison, WI, and London: University of Wisconsin Press, 1985.

Reinhard, Wolfgang. "Reformation, Counter-Reformation, and the Early Modern State: An Assessment." In The Counter-Reformation: The Essential Readings, ed. David M. Luebke, 105-28. Malden, MA: Blackwell, 1999.

Rietbergen, Peter J.A.N. "Printing Baronius's Annales Ecclesiastici (Rome, 1588-1607)." Quaerendo 13, no. 2 (1983): 87-102.

Roest, Bert. "Later Medieval Institutional History." In Historiography in the Middle Ages, ed. Deborah Mauskopf Deliyannis, 277-315. Brill: Leiden and Boston, 2003.

Rosen, Edward. "Maurlico's Attitude toward Copernicus." Proceedings of the American Philosophical Society 101, no. 2 (April 1957): 177-94.

Rowe, Erin Kathleen. Saint and Nation: Santiago, Teresa of Avila, and Plural Identities in Early Modern Spain. University Park, PN: Pennsylvania State University Press, 2011.

Rubenstein, Jay. "Biography and Autobiography in the Middle Ages." In Writing Medieval History, ed. Nancy Partner, 22-41. London: Hodder, 2005.

Saenger, Paul. Space between Words: the Origins of Silent Reading. Stanford, CA: Stanford University Press, 1997.

Scribner, Robert. "Oral Culture and the Diffusion of Reformation Ideas." History of European Ideas 5, no. 3 (1984): 237-56. 
—_. "Incombustible Luther: The Image of the Reformer in Early Modern Germany." Past and Present 110 (February 1986): 38-68.

—_. For the Sake of Simple Folk: Popular Propoganda for the German Reformation. New York: Oxford University Press, 1994.

Sherman, William H. Used Books: Marking Readers in Renaissance England. Philadelphia: University of Pennsylvania Press, 2008.

Slights, William W.E. Managing Readers: Printed Marginalia in English Renaissance Books. Ann Arbor, MI: University of Michigan Press, 2001.

Smith, Hilary Dansey. Preaching in the Spanish Golden Age. Oxford: Oxford University Press, 1978.

Sot, Michel. "Local and Institutional History (300-1000)." In Historiography in the Middle Ages, ed. Deborah Mauskopf Deliyannis, 89-114. Brill: Leiden and Boston, 2003.

Spiegel, Gabrielle. "Genealogy: Form and Function in Medieval Historical Narrative." History and Theory 22, no. 1 (February 1983): 43-53.

Stock, Brian. The Implications of Literacy. Princeton: Princeton University Press, 1983.

- Augustine the Reader: Meditation, Self-Knowledge, and the Ethics of Interpretation. Cambridge, MA: Harvard University Press, 1996.

Taylor, Bruce. Structures of Reform: The Mercedarian Order in the Spanish Golden Age. Leiden and Boston: Brill, 2000.

Thomson, Francis J. "The Popularity of Peter Skarga's Lives of the Saints." In For East is East: Liber amicorum Wojciech Skalmowski, eds. Tatjana Soldatjenkova and Emmanuel Waegemans, 119-49. Louvain: Peeters, 2003.

Torrell, Jean-Pierre. Saint Thomas Aquinas: His Life and his Works. 2 vols. Trans. Robert Royal. Rev. ed. Washington, D.C.: Catholic University of America Press, 2005.

Van Liere, Katherine Elliott. "The Missionary and the Moorslayer: James the Apostle in Spanish Historiography from Isidore of Seville to Ambrosio de Morales." Viator 37 (2006): 519-43.

Walker, John Bernard. The "Chronicles" of Saint Antoninus: A Study in Historiography. Washington, D.C.: Catholic University of America, 1933. 
Weber, Alison. Teresa of Avila and the Rhetoric of Feminity. Princeton, NJ: Princeton University Press, 1990.

Weinstein, Donald, and Rudolph M. Bell. Saints and Society: Two Worlds of Christendom, 1000-1700. Chicago and New York: University of Chicago Press, 1982.

Wiess, James Michael. "Luther and His Colleagues on the Lives of Saints." Harvard Library Bulletin 33, no. 2 (1985): 174-95.

Wojtyska, Henricus Damianus. "Introductio." In Acta nuntiaturae Polonae, 3, no. 1, Aloisius Lippomano (1555-1557), ed. Henricus Damianus Wojtyska, v-xxix. Rome: Institutum historicum polonicum Romae, 1993.

Zarri, Gabriella. "Gender and Religious Autobiography between the Reformation and the Counter-Reformation: Typologies and Examples." In Saints, Scholars, and Politicians: Gender as a Tool in Medieval Studies, eds. Mathilde van Dijk and Renée Nip, 227-40. Turnhout: Brepols, 2005.

Županov, Ines G. Missionary Tropics: The Catholic Frontier in India $\left(16^{\text {th }}\right.$ and $17^{\text {th }}$ Centuries). Ann Arbor, MI: University of Michigan Press, 2005.

\section{Tertiary Sources (see also Abbreviations, p. xi)}

The Brill Dictionary of Gregory of Nyssa. Eds. Lucas Francisco Mateo-Seco and Giulio Maspero. Trans. Seth Cherney. Leiden: Brill, 2009.

Butler, Alban. Butler's Lives of the Saints. Ed. Sarah Fawcett Thomas. 12 vols. Tunbridge Wells, UK, and Collegeville, MN: Burns \& Oates and Liturgical Press, 1995-2000.

Elliott, J.H. Imperial Spain, 1469-1716. London: Edward Arnold, 1963. Reprint, London: Penguin, 2002.

Hoefer, Jean-Chrétien-Ferdinand. Nouvelle biographie générale depuis les temps les plus reculés jusqu'à nos jours. 46 vols. Paris: Firmin Didot Frères, 1853-66. 